\title{
Oil Shale, Water Resources, and Valuable Minerals of the Piceance Basin, Colorado: the Challenge and Choices of Development
}

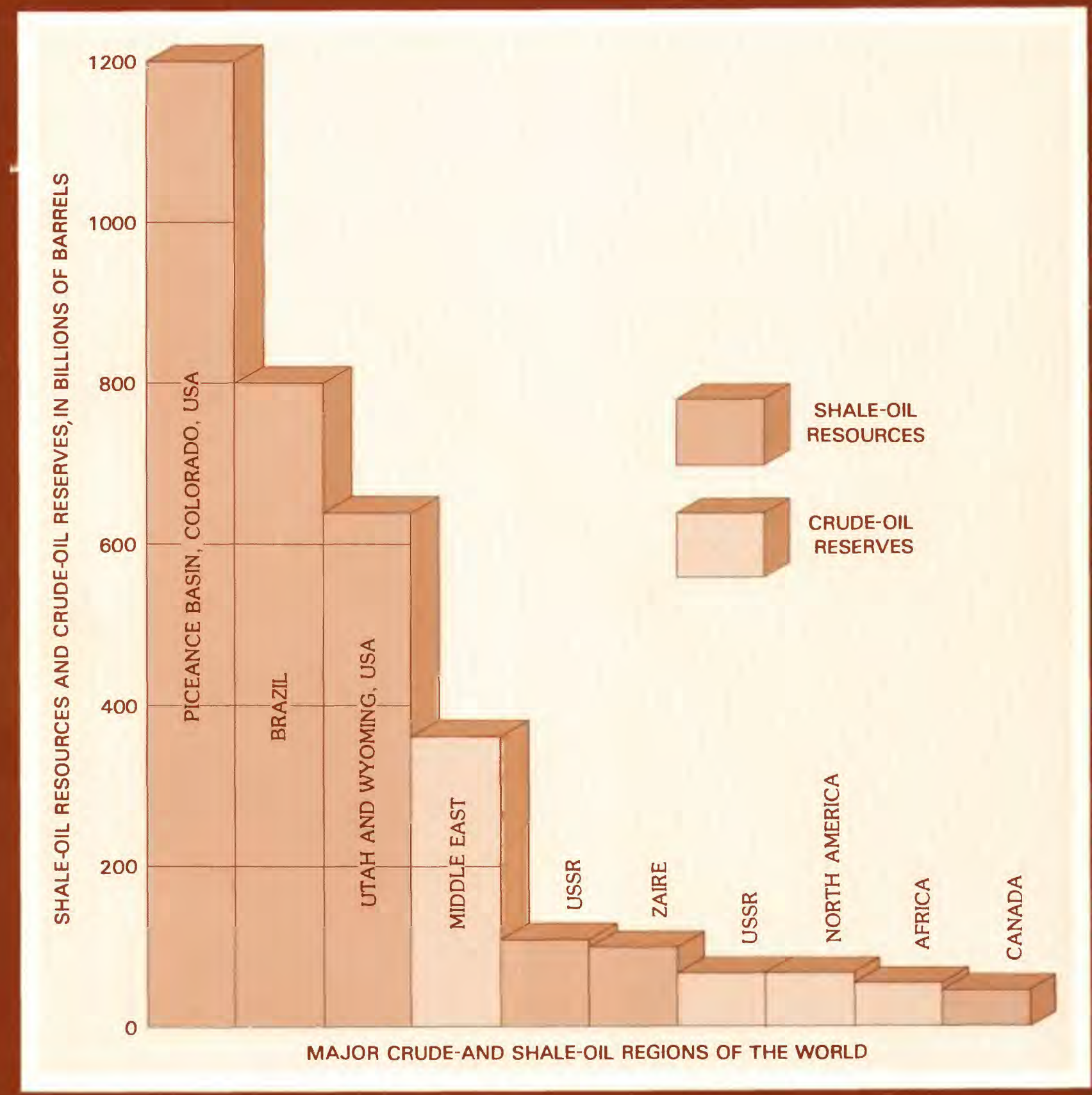

U.S. GEOLOGICAL SURVEY PROFESSIONAL PAPER 1310 
COVER: Estimated shale-oil resources and crude-oil reserves in selected regions of the world. Economic extraction of the shale-oil resources is currently or potentially feasible, but the part of the shale oil that is actually recoverable can only be estimated. The crude-oil reserves represent the volume of crude oil that could be economically extracted or produced at the present. Estimates of resources and reserves need to be adjusted continually to account for new discoveries, additional field data, changes in processing methods, and depletion during development. 


\section{OIL SHALE, WATER RESOURCES, AND VALUABLE MINERALS OF THE PICEANCE BASIN, COLORADO:}

THE CHALLENGE AND CHOICES OF DEVELOPMENT

Compiled by O. JAMES TAYLOR

U.S. GEOLOGICAL SURVEY PROFESSIONAL PAPER 1310 


\section{DEPARTMENT OF THE INTERIOR DONALD P. HODEL, Secretary U.S. GEOLOGICAL SURVEY Dallas L. Peck, Director}

Oil shale, water resources, and valuable minerals of the Piceance basin, Colorado.

(Geological Survey professional paper ; 1310)

Bibliography: p.

Supt. of Docs. no.:I 19.16:1310

1. Oil-shales-Colorado-Piceance Creek Watershed. 2. Water-supply-Colorado-Piceance Creek Watershed. 3. Mines and mineral resources-Colorado-Piceance Creek Watershed.

I. Taylor, O. James. 11 . Series.
TN859.U52P536
1987
$553.2^{\prime} 82$
$83-600336$

For sale by the

Books and Open-File Reports Section

U.S. Geological Survey

Federal Center

Box 25425

Denver, CO 80225 



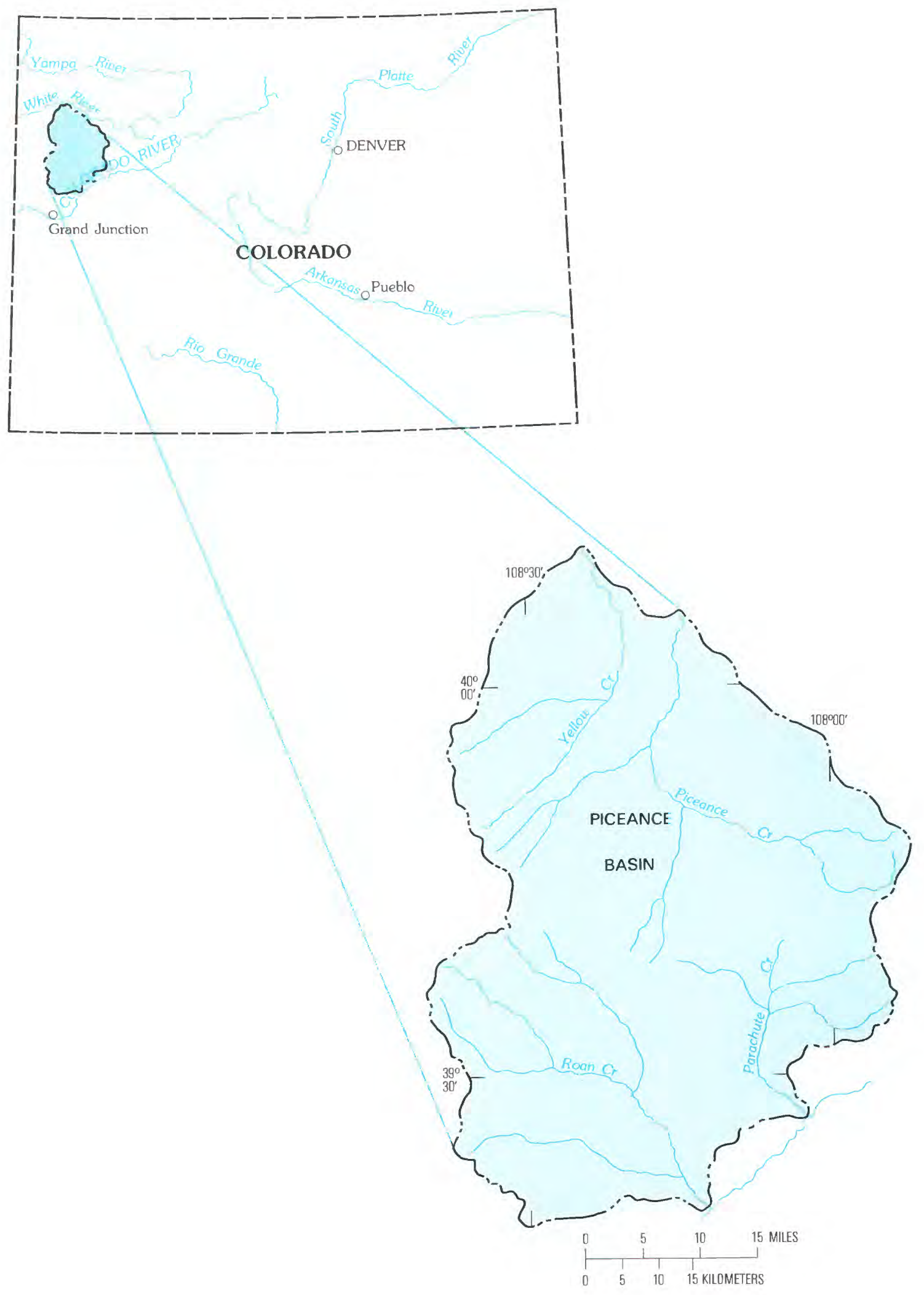




\section{FOREWORD}

The Piceance basin of northwestern Colorado contains vast resources-large quantities of oil shale, valuable minerals, and water. The development of these resources could benefit our Nation by satisfying the future requirements of industry, agriculture, and municipalities.

The origin, abundance, and development of these resources are being studied by government, industry, and universities. Investigations indicate that the shale oil, minerals, and water occur together in complex relations that are only partly understood, and more intensive studies are needed if these resources are to be properly developed. Large-scale development of oil shale will require tremendous quantities of water. Unexplored ground-water reservoirs may be able to provide part of the required supplies. Because development may also affect the streams, ground water, and atmosphere, well-planned controls are needed. Proper resource development also will require close cooperation between industry and various levels of government.

This paper was prepared by a variety of specialists within the U.S. Geological Survey. The technical information is presented in a clear, graphic manner to enable the report to be understood by a wide spectrum of readers and to provide them with a broad understanding of the challenge and choices of development of the shale oil, minerals, and water resources of the Piceance basin.

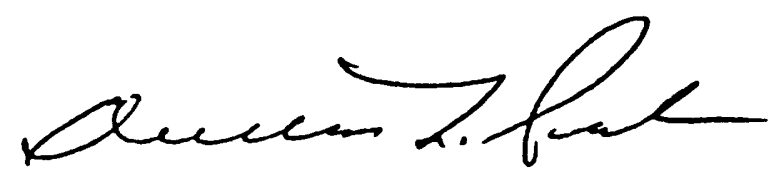

Dallas L. Peck, Director

U.S. Geological Survey 


\section{CONTENTS \\ DEFINITIONS AND SYNOPSIS}

Page

\section{GLOSSARY}

A variety of technical terms describe the minerals, geology, and hydrology of the

Piceance basin and the proposed resource development.

\section{INTRODUCTION}

\section{By O. James Taylor}

The Piceance basin lies in northwestern Colorado and contains large quantities of oil shale, associated minerals, and other minerals. The occurrence of major minerals and the development, benefits of development, and impacts of development of oil shale are described in this report.

\section{GEOLOGY, MINERALS, AND MINERAL DEVELOPMENT}

\section{GENERAL GEOLOGY OF THE PICEANCE BASIN}

By Marjorie E. MacLachlan

The Piceance basin is a structural basin, a depositional basin, and several drainage basins. The oil shale, associated minerals, and thousands of feet of sedimentary rock were deposited during Tertiary time, at the end of the period of deformation that shaped the structural basin.

\section{ORIGIN OF THE OIL SHALE AND ASSOCIATED MINERALS}

By John R. Dyni

Oil shale, nahcolite, and dawsonite originated in ancient lakes.

STOREHOUSE OF ENERGY MINERALS IN THE PICEANCE BASIN By John R. Donnell

The Piceance basin contains natural gas, crude oil, and coal, as well as shale oil, nahcolite, and dawsonite. 
VIII

CONTENTS

DEVELOPMENT OF THE OIL SHALE AND ASSOCIATED MINERALS

By G. A. Miller

Mineral development will disrupt natural conditions in the basin because of the required mining, retorting, water development, mineral transportation, and reclamation.

\title{
RELATIONS AMONG THE GEOLOGIC, HYDROLOGIC, AND GEOCHEMICAL CHARACTERISTICS OF THE BASIN
}

\author{
SYSTEMATIC JOINTS WITHIN OIL SHALES AND ASSOCIATED \\ ROCKS OF THE GREEN RIVER FORMATION \\ By Earl R. Verbeek and Marilyn A. Grout
}

Joints and fractures of the Green River Formation form systematic patterns. The joints and fractures affect the occurrence of ground water and mine stability.

\section{UNCONSOLIDATED DEPOSITS OF THE PICEANCE BASIN}

By Frank A. Welder

The unconsolidated deposits that overlie the bedrock contain water and are part of the hydrologic systems in the stream valleys.

\section{HYDROLOGIC SYSTEM OF THE PICEANCE BASIN}

By O. James Taylor

Surface water and ground water flow in complex systems. An understanding of the flow systems is obtained by preparing models that simulate the systems under various conditions. Water supplies in the Piceance basin belong to the public, but are regulated by the State of Colorado.

\section{SUSPENDED SEDIMENT IN PICEANCE CREEK} By Vernon W. Norman

Studies of suspended sediment in Piceance Creek indicate a high erosion potential in the drainage basin under natural conditions. Increased erosion and transport of sediment may result from mining and waste-disposal activities.

\section{WATER QUALITY IN THE PICEANCE BASIN}

By Robert L. Tobin

The quality of surface water and ground water is highly variable and probably will 
A study of aquatic insects can be used to assess natural and man-induced changes

\section{PLANNING FOR MINERAL DEVELOPMENT: ALTERNATE WATER SUPPLIES AND EFFECTS OF RETORTS}

\section{PALEOZOIC AND MESOZOIC FORMATIONS AND THEIR}

POTENTIAL AS GROUND-WATER RESERVOIRS

By Marjorie E. MacLachlan and Frank E. Welder

Paleozoic and Mesozoic formations indicate a varied geologic history. These forma-

\section{CHEMICAL EFFECTS AND CONTROL OF LEACHATES FROM}

OIL-SHALE SPOIL PILES

By Kenneth G. Stollenwerk

Spoil piles of retorted shale need to be designed, located, and maintained carefully

\section{CHEMICAL EFFECTS AND CONTROL OF WASTES FROM}

IN SITU RETORTS

By Jerry A. Leenheer

Underground retorts may produce a variety of wastes within the ground-water reservoirs.

\section{EFFECTS OF EMISSIONS FROM OIL-SHALE RETORTS TO}

THE ATMOSPHERE

By John T. Turk

Industrial emissions to the atmosphere may affect precipitation and lakes.

\section{LEVELS OF MINERAL DEVELOPMENT}

\section{BENEFITS, REQUIREMENTS, AND EFFECTS OF DIFFERENT LEVELS \\ OF OIL-SHALE DEVELOPMENT \\ By O. James Taylor}




\section{ADDITIONAL INFORMATION}

\section{RECOMMENDED READING}

The minerals, geology, hydrology, and resource development are described in greater

detail in other publications.

\section{EPILOGUE}

EPILOGUE

By O. James Taylor

\section{ILLUSTRATIONS}

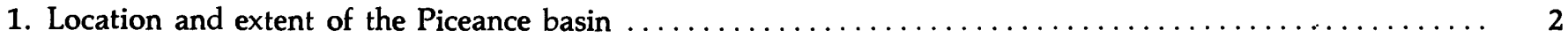

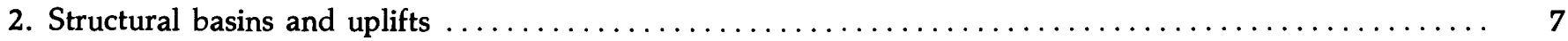

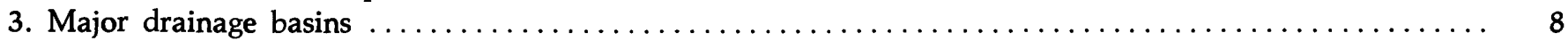

4. General geologic map of northwestern Colorado $\ldots \ldots \ldots \ldots \ldots \ldots \ldots \ldots \ldots \ldots \ldots \ldots \ldots \ldots \ldots . \quad 9$

5. Principal formations of Tertiary age exposed near Anvil Points, in the southeast part of the Piceance basin 11

6. Diagrammatic east-west cross section, northwestern Colorado $\ldots \ldots \ldots \ldots \ldots \ldots \ldots \ldots \ldots \ldots \ldots \ldots \ldots$

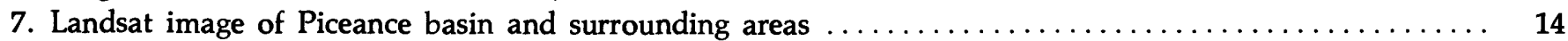

8. Maximum extent of ancient Lakes Uinta and Gosiute during Eocene time $\ldots \ldots \ldots \ldots \ldots \ldots \ldots \ldots \ldots 17$

9. Polished slab of siltstone (light tan) and medium- to high-grade oil shale (brown to dark brown) from the

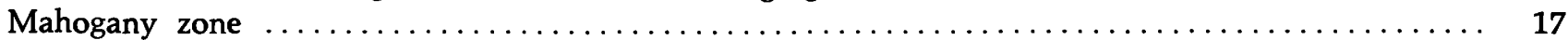

10. Drill core of interbedded coarse crystalline white nahcolite with dark-colored oil-shale layers $\ldots \ldots \ldots .18$

11. Nahcolite and halite deposited in the deep parts of Lake Uinta during dry climatic periods $\ldots \ldots \ldots \ldots .18$

12. Deposition of nahcolite, dawsonite, halite, and oil shale in Lake Uinta $\ldots \ldots \ldots \ldots \ldots \ldots \ldots \ldots \ldots$

13. Drill core showing coarse crystalline scattered aggregates of nahcolite in high-grade oil shale ........ 20

14. Drill core of alternating thin beds of nahcolite and halite in which drilling fluid has dissolved part of the halite

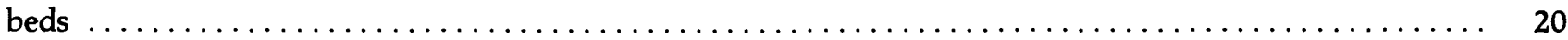

15. Location of large concentrations of energy minerals in the stratigraphic column $\ldots \ldots \ldots \ldots \ldots \ldots \ldots, 22$

16. Rich and lean oil-shale zones in part of the Green River Formation in the Piceance basin $\ldots \ldots \ldots \ldots .23$

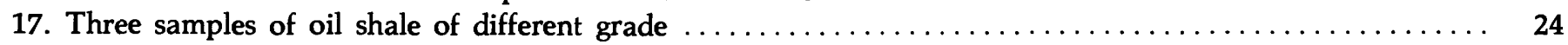

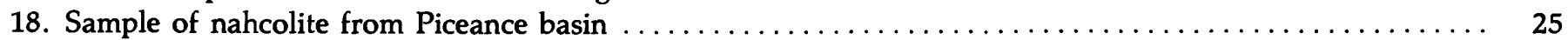

19. Total shale-oil resources and overburden thickness above the Mahogany zone $\ldots \ldots \ldots \ldots \ldots \ldots \ldots \ldots$

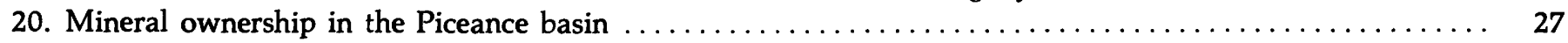

21. Modern and historic sites related to oil-shale development $\ldots \ldots \ldots \ldots \ldots \ldots \ldots \ldots \ldots \ldots \ldots \ldots \ldots, 30$

22. Spoil pile of retorted shale from the experimental retort of the U.S. Bureau of Mines, $1925-29 \ldots \ldots \ldots 31$

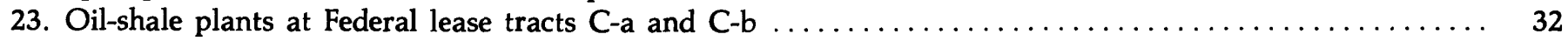

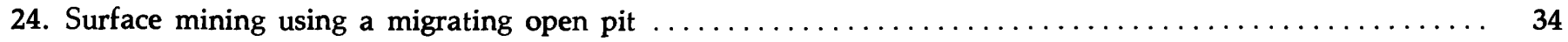

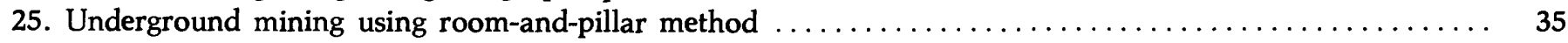

26. Samples of crushed but unretorted oil shale and retorted oil shale from field tests, Rulison site, $1928 \ldots \ldots 36$

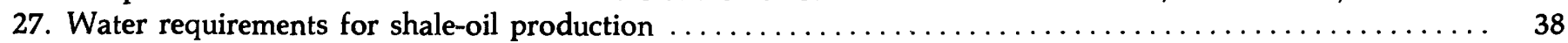

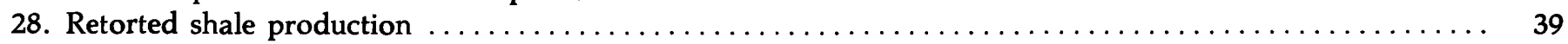

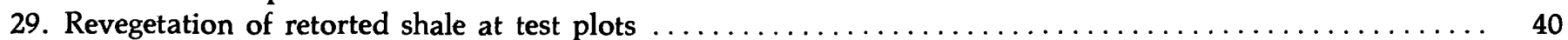

30. A well-developed set of joints, with an average spacing of about one foot, within moderate-grade oil shales

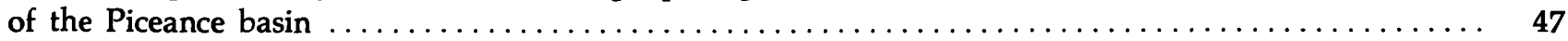

31. A set of $F_{2}$ joints in moderately rich oil shales near the mouth of Piceance Creek $\ldots \ldots \ldots \ldots \ldots \ldots, 48$

32. Schematic block diagram of joint sets in the Green River Formation $\ldots \ldots \ldots \ldots \ldots \ldots \ldots \ldots \ldots \ldots .51$ 
33. Relation between spacing of $F_{2}$ joints and bed thickness for fine-grained sandstones and siltstones of the Green

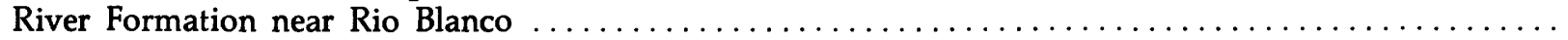

34. Closely spaced joints in an upper lean zone, about six feet thick, and widely spaced in joints in a lower rich

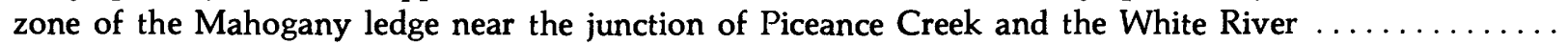

35. Locations of cross sections where the valley-fill alluvium was explored by drilling $\ldots \ldots \ldots \ldots$

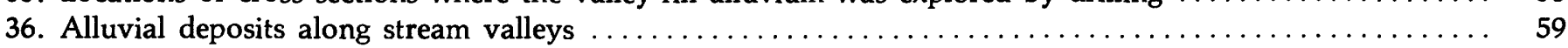

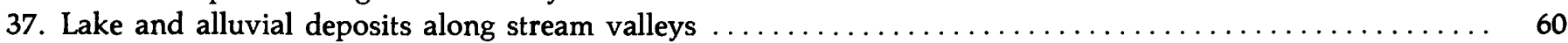

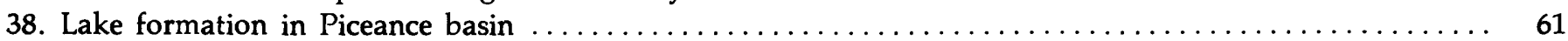

39. Aerial view showing the displacement of Piceance Creek toward a county road by an alluvial fan at the mouth

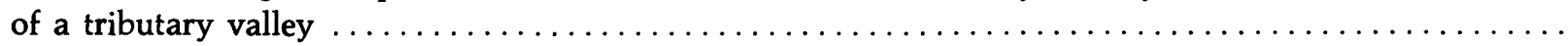

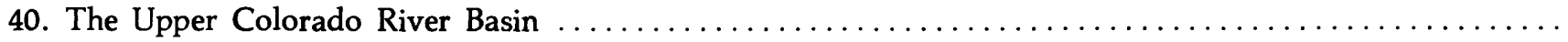

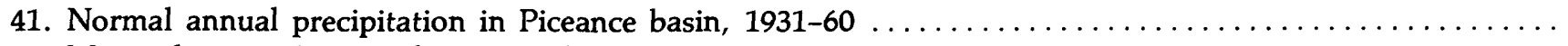

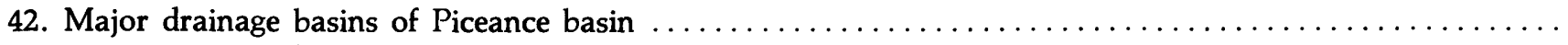

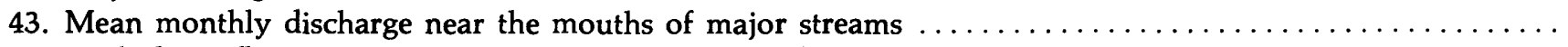

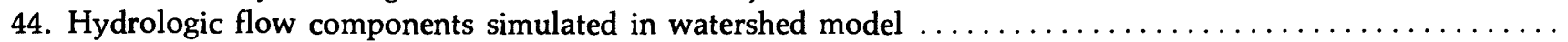

45. Map of drainage basin subdivided into hydrologic response units for watershed modeling $\ldots \ldots \ldots \ldots . . .$.

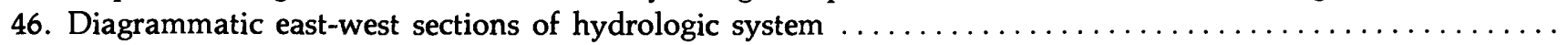

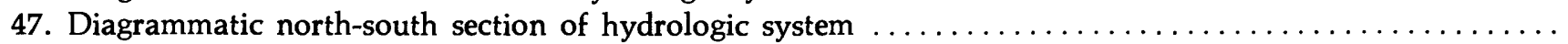

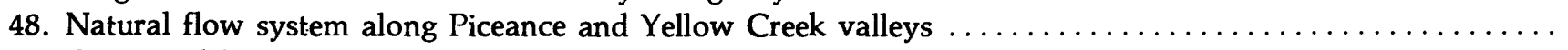

49. Gains and losses along selected reaches of Piceance Creek, March 26, $1981 \ldots \ldots \ldots \ldots$

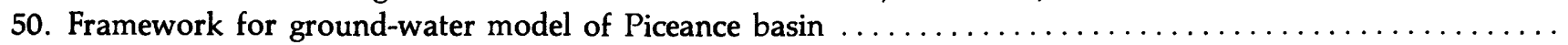

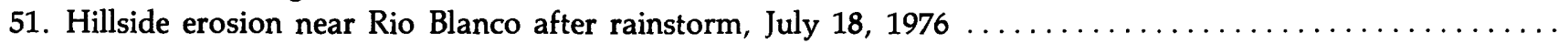

52. Turbid water in Piceance Creek near Rio Blanco, July 17, $1977 \ldots \ldots \ldots \ldots \ldots \ldots \ldots \ldots \ldots \ldots \ldots \ldots \ldots \ldots$

53. Coarse sediment deposited on highway near Piceance Creek during intense rainstorm, July 19, 1977 .....

54. Typical yearly distribution of sediment load in streams in the Piceance basin $\ldots \ldots \ldots \ldots \ldots \ldots$

55. Deeply cut channel in streambed of Corral Gulch, resulting from well discharge, April 3, 1978 .......

56. Dominant chemical constituents in the two major bedrock aquifers $\ldots \ldots \ldots \ldots \ldots \ldots \ldots \ldots \ldots \ldots \ldots$

57. Alkali flats, marked by white salts on the land surface in Piceance Creek valley, with White River valley in

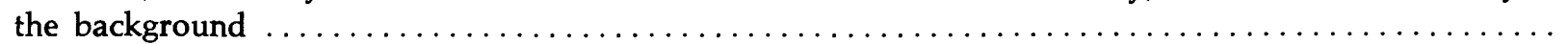

58. Flow and water-quality variations in Piceance Creek, March 26, $1981 \ldots \ldots \ldots \ldots$

59 . Benthic invertebrates as part of the animal kingdom $\ldots \ldots \ldots \ldots \ldots \ldots \ldots \ldots \ldots \ldots \ldots \ldots \ldots \ldots \ldots \ldots \ldots \ldots \ldots$

60. Changes in dissolved-oxygen concentration in streams and related changes in groups of benthic invertebrates

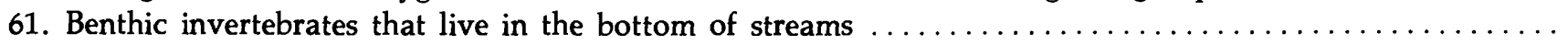

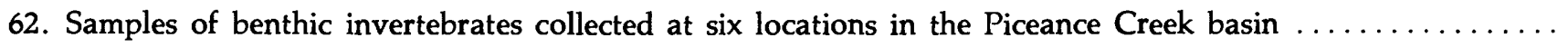

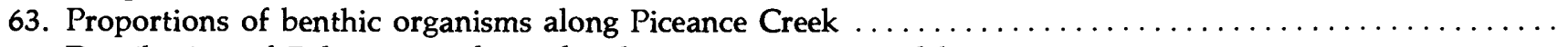

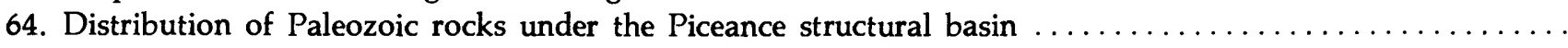

65. Water draining from the Leadville Limestone, flowing into Rifle Creek and over Rifle Falls ...........

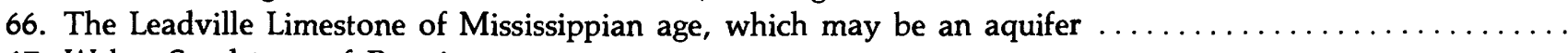

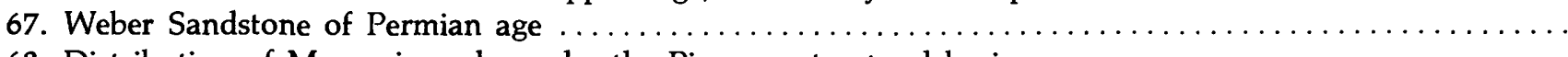

68. Distribution of Mesozoic rocks under the Piceance structural basin $\ldots \ldots \ldots \ldots \ldots \ldots$

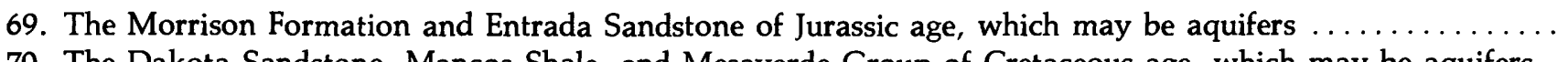

70. The Dakota Sandstone, Mancos Shale, and Mesaverde Group of Cretaceous age, which may be aquifers .

71. Diagrammatic east-west cross section, northwestern Colorado, showing distribution of rocks for systems of

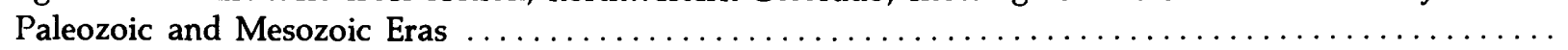

72. Concentrations of dissolved solids, molybdenum, fluoride, and boron in leachate from three different types

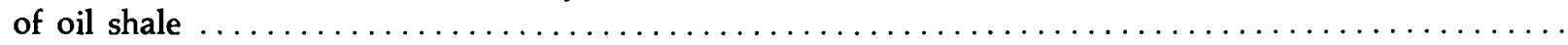

73. Possible movement of toxic substances leaching from oil-shale spoil piles $\ldots \ldots \ldots \ldots \ldots \ldots$

74. Mine drainage, water reinjection, and wastewater disposal during in situ retort construction ..........

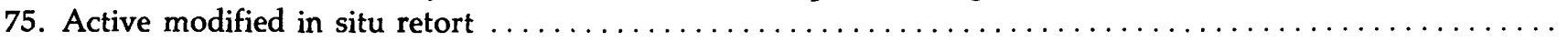

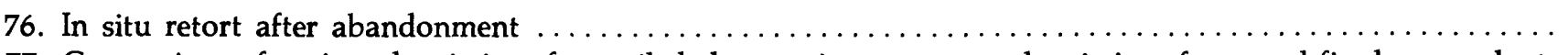

77. Comparison of projected emissions from oil-shale retorting to measured emissions from coal-fired powerplants

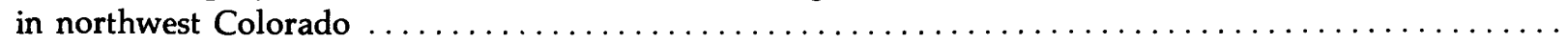

78. Predominant wind directions in northwestern Colorado $\ldots \ldots \ldots \ldots \ldots \ldots \ldots \ldots \ldots \ldots \ldots \ldots \ldots \ldots \ldots \ldots$

79. Titration curves that indicate the effects of adding acid to pure water and to water samples from lower Marvine Lake and upper Island Lake 
80. Upper Island Lake (very susceptible to acidification), located in the eastern part of the Flat Tops Wilderness

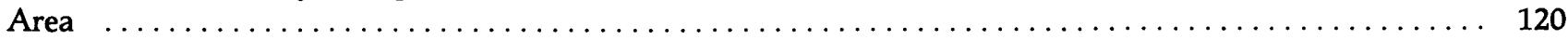

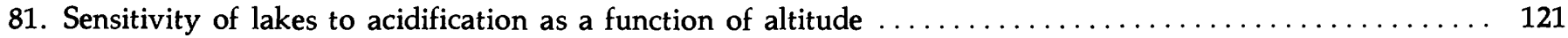

82. Simulation models to quantify the range in lake acidity as a function of emissions $\ldots \ldots \ldots \ldots \ldots \ldots 121$

83. Effects of different levels of oil development from shale on National oil supplies ................ 126

84. Estimated maximum available water supplies for oil-shale development in Piceance basin $\ldots \ldots \ldots \ldots \ldots 128$

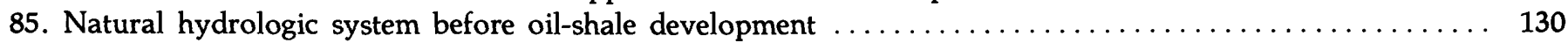

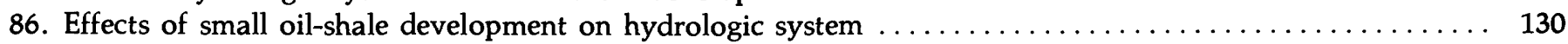

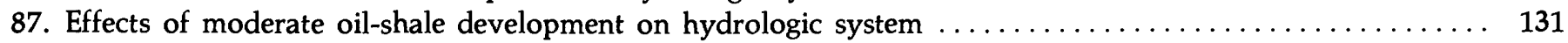

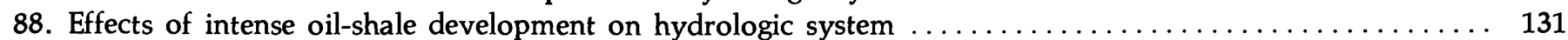

89. Effects of presumed levels of oil development from shale on regional water supplies $\ldots \ldots \ldots \ldots \ldots \ldots 132$

90. Estimated effects of presumed levels and types of oil development from shale on water resources . . . . 134

\section{TABLES}

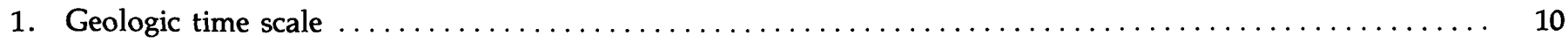

2. Stratigraphic column of Tertiary rocks between the Colorado and White Rivers $\ldots \ldots \ldots \ldots \ldots \ldots \ldots, 12$

3. Characteristics of joint sets in the Green River Formation $\ldots \ldots \ldots \ldots \ldots \ldots \ldots \ldots \ldots \ldots \ldots \ldots \ldots \ldots$

4. Correlation chart showing Paleozoic and Mesozoic Formations $\ldots \ldots \ldots \ldots \ldots \ldots \ldots \ldots \ldots \ldots \ldots \ldots$

5. Potential surface-water supplies for oil-shale development in Piceance basin $\ldots \ldots \ldots \ldots \ldots \ldots \ldots \ldots, 128$ 


\section{DEFINITIONS AND SYNOPSIS}




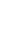




\section{GLOSSARY}

Aboveground retort. - A large container in which crushed oil shale is heated in order to decompose the kerogen into oil and light hydrocarbon gases.

Acidity.-The ability of a solution to neutralize strong bases.

Alkalinity. - The ability of a solution to neutralize strong acids.

Alluvial deposit. - Unconsolidated sedimentary material such as clay, sand, and gravel that is eroded from bedrock, transported, and laid down by flowing water. Also known as alluvium.

Appropriation. - The diversion and use of a specified quantity of water for a specified beneficial use.

Aquatic environment. - The sum of all the external physical, chemical, and biological conditions and influences that affect the life and development of an organism in a body of water. The environment surrounding an aquatic organism is rarely constant. The quality of an individual's life in an aquatic world is directly dependent on the quality of its environment.

Aquifer.-A geologic formation, group of formations, or part of a formation that transmits water readily and can supply wells or springs. Also may be regarded as an underground reservoir.

Atmospheric-transport and deposition model.-A mathematical description of the characteristics of the regional atmosphere, climate, and land forms that control the migration of airborne particles and gases from a source to a site of deposition or dispersion.

Benthic invertebrate. - An animal without a backbone that lives in or on the bottom of an aquatic environment. Included are organisms such as insects, worms, snails, clams, and leeches.

Biochemical degradation. - The alteration or breakdown of a compound directly or indirectly by microorganisms such as bacteria or algae.

Calcining.-Conversion of minerals into a calcium and magnesium oxide by burning and roasting.

Clastic rock. $-\mathrm{A}$ rock that originates as broken fragments of preexisting rocks that are mechanically transported and reconsolidated. Examples include sandstone and shale.

Continental. - Formed on land masses or within freshwater lakes.

Crude oil.-Naturally occurring petroleum, as it comes from an oil well.
Dawsonite. $-\mathrm{NaAl}(\mathrm{OH})_{2} \mathrm{CO}_{3}: \mathrm{A}$ rare carbonate mineral containing sodium and aluminum that was first discovered in a dike near McGill University, Montreal, Canada. Dawsonite is a possible source of aluminum oxide and other chemicals used in industry. In recent years the mineral has been found in small amounts in sedimentary rocks in Australia, Russia, Tanzania, and Alaska. The world's largest occurrence is in the Colorado oil-shale deposits where it locally comprises about 10 percent by weight of the oil shale.

Depositional basin. - A basin that originates because of, or includes, the accumulation of sediments in a low region of the crust of the Earth.

Diffusion.-A process of natural scattering in which constituents migrate because of differences in concentration or temperature.

Dip. - The inclination of a geologic bed, joint, fracture, or any planar geologic feature; measured as an angle below the horizontal.

Dispersion.-A process of natural scattering in which constituents or contaminants migrate because of the characteristics of the flow system.

Dissolved oxygen. - Oxygen that is dissolved in water. The oxygen comes from the atmosphere or is produced by aquatic plants during photosynthesis. Respiration by aquatic plants, animals, and bacteria consumes dissolved oxygen. A low concentration of dissolved oxygen in streams or lakes may indicate degraded water quality.

Drainage basin. - A land area that collects precipitation water and drains it to a stream system, lake, or reservoir.

Evapotranspiration. - Loss of water by evaporation from wet surfaces and by transpiration through plants.

Fan deposit. - A cone-shaped sedimentary deposit that results when streams deposit sediment as they flow from highlands onto lowlands. Also called an alluvial fan.

Fault. - A natural break in rock strata that may or may not result in displacement.

Filtration. - The separation of suspended solids from water by passage through a natural or artificial porous barrier.

Flood plain. - The strip of relatively flat land along a stream channel that is underlain by sediment deposited by the stream. The flood plain is covered by water during floods.

Food chain. - A series of organisms in which the larger feed on the smaller. 
Fracture. - A break in a rock due to mechanical failure under stress. A general term that includes faults, joints, and cracks.

Gain-and-loss study. - A series of stream-discharge measurements that are used to account for all changes in streamflow and to calculate the exchange of water between the stream and connected aquifer.

Geophysical log. - A record of various characteristics of rock formations that is obtained by lowering a probe down a well or test hole, making measurements, and recording them using surface instruments. The measured characteristics include the physical, electrical, acoustical, or chemical properties of the formations. The interpretation of these characteristics is helpful in exploring for minerals and in determining rock properties.

Ground-water model. - The mathematical description of a ground-water system used to simulate and study the behavior of the system, under existing, hypothetical, or proposed conditions.

Ground-water reservoir. - An aquifer system that can be utilized to store and withdraw water. Access to a groundwater reservoir is normally through wells.

Halite. $-\mathrm{NaCl}$ : the mineral name for common table salt; occurs comingled with nahcolite in beds as thick as 70 feet in the Colorado oil-shale deposits.

Hydrocarbon trap. - A stratigraphic or structural barrier to the upward migration of oil and gas that permits accumulation in a reservoir.

Igneous intrusive rock. - A rock that originates in the molten or partially molten state, invades other rocks, and then solidifies.

In situ retort. - An oil-shale retort that is constructed using a cavity mined within the ore, underground, in order to reduce mining costs.

Infiltration. - The general process by which water flows into porous material. For example, precipitation water passing through the land surface and into the zone below, or water passing into a pile of waste material.

Ion.-An electrically charged atom or group of atoms that results from the loss or gain of electrons. Most dissolved minerals in water occur as ions.

Ion-exchange reactions. - Chemical reactions in which ions in solution are exchanged with chemical elements in other materials. For example, calcium ions in solution commonly replace sodium in clay, releasing the sodium into solution.

Joint. - A fracture without significant displacement in a rock. Parallel joints are called joint sets.

Kerogen.-A solid, insoluble organic material found in sedimentary rocks, that can be converted to petroleum products by destructive distillation. Diesel fuel can be made easily from these petroleum products; gasoline can be made also, but requires more upgrading.
Landsat image. - An image of the Earth's surface obtained by sensors on a satellite. The data obtained by the sensors are stored on magnetic tape, either on the satellite or at a ground station. Eventually the data are processed and often used to prepare an image on film for inspection and analysis. The area on the ground that is shown in an image is a scene.

Leachate. - Soluble chemical constituents removed by percolating water from a mass of material, such as a spoil pile of retorted shale.

Lean oil shale. - For this report, oil shale that contains 15 gallons of oil or less per ton of rock.

Leasing. - A method by which one who desires to explore or develop minerals owned by another can contract with and pay the owner for these privileges. The owner is called the lessor; the one who leases for exploration or development is called the lessee.

Lineament. - A linear feature on the surface of the Earth that may be an expression of fractures and faults in the rocks below.

Locatable mineral. - A mineral deposit that can be possessed by one who marks the boundaries of his mining claim on the ground and publicly proclaims his claim in the proper manner.

Marine.-Formed in an ocean environment; for example, limestone.

Marl. - A poorly consolidated rock that consists of a mixture of clay and calcium carbonate and is formed in the bottoms of lakes, ponds, and marshes.

Marlstone. - A consolidated rock that consists of a mixture of shale and calcium carbonate.

Mine roof. - The ceiling or back in an underground mine. Mining claim. -A portion of the public mineral lands which a miner, for mining purposes, takes and holds in accordance with mining laws.

Model.-The mathematical description of a process or system that is used to simulate, study, and predict the behavior of the system under a variety of conditions.

Model calibration. - In hydrology, a process in which the simulated results from a model are compared with measurements onsite. The model is adjusted until the model results and field measurements are similar or equal. A calibrated model is likely to be more accurate in forecasting than an uncalibrated model.

Modified in situ retort. - A special type of in situ retort in which 20 to 40 percent of the oil shale is mined. The remaining ore is blasted into fragments. Air and gas are injected into the retort and the fragmented shale is ignited at the top of the retort using an external fuel source. As burning proceeds downward, the heat retorts the underlying oil-shale fragments, and shale oil and gases flow downward to a collection site. 
Nahcolite. $-\mathrm{NaHCO}_{3}$; a naturally occurring sodium bicarbonate mineral having the same chemical composition as household baking soda. Nahcolite is a potential source of several chemicals used in industry including the removal of sulfur from exhaust gases. The name of the mineral is derived from the chemical formula, $\mathrm{Na}-\mathrm{H}-$ CO-lite.

Natural discharge. - Loss of water from a ground-water reservoir, as to a spring or stream.

Natural recharge. - Addition of water to a ground-water reservoir, as by infiltration from precipitation, a lake, or a stream.

Node. - In ground-water modeling, an imaginary volume of a ground-water flow system within which the hydrologic characteristics are assumed to be uniform. By coupling the hydrologic characteristics of the array of nodes of a flow system with the proper flow equations, a ground-water model is constructed.

Normal annual precipitation. - The average annual precipitation recorded from 1931 to 1960 .

Oil shale. - A sedimentary rock that contains kerogen and yields hydrocarbon material when heated.

Orogeny. - The process by which structures within mountain areas are formed, including uplift, thrusting, faulting, and folding.

Overburden. - The consolidated or unconsolidated rock material that overlies a mineral deposit.

$p H$. - A chemical symbol used to specify the hydrogen ion concentration in a solution. It is defined as the negative base 10 logarithm of the hydrogen ion concentration in moles per liter. A pH of 7.0 indicates a neutral solution, below 7.0 is acidic, and above 7.0 is alkaline.

Permeability. - A property of consolidated or unconsolidated material that describes the ease with which a fluid may move through openings in the material under standard conditions. Material of high permeability may transmit large quantities of a fluid in a short time; material of low permeability may transmit large quantities of a fluid in a long time and (or) over a large area.

Porosity. - The volume of the void space of a rock, expressed as a fraction or percentage of the volume of the whole rock.

Primary permeability. - Rock permeability that is due to interconnected openings that were formed during deposition, such as the pores in a sandstone aquifer.

Radiometric dating. - The calculation of the age of a rock, mineral, or water sample by chemical analysis to determine the extent of decomposition of included radioactive elements.

Remote sensing. - A technique for detecting the nature or condition of the Earth's surface without touching it.

Reserve. - The part of an identified resource that can be extracted and produced economically.
Resource.-A concentration of naturally occurring solid, liquid, or gaseous material in or on the Earth's crust in such form and amount that economic extraction of a commodity from the concentration is currently or potentially feasible.

Retort. - A vessel used to heat crushed oil shale and extract the organic material. This material is converted to useful petroleum products.

Rich oil shale. - For this report, oil shale that contains 15 gallons of oil or more per ton of rock.

Room-and-pillar mine.-An underground mine in which large rooms are excavated by access through a shaft or adit. The mine roof is supported by unmined rock called pillars. These pillars may be removed later during withdrawal from the mine.

Rubblize.-To break rock into rough fragments using explosives, in preparation for in situ retorting of oil shale.

Scrubbing equipment. - Apparatus used to cleanse gases and vapors of impurities before they are released from a processing plant.

Secondary permeability. - Rock permeability due to interconnected openings formed after deposition, such as fractures or solution channels.

Sedimentary rock. - A rock formed by the consolidation of accumulated loose sediments. The sediment originates as mechanically broken fragments during erosion, chemical precipitates from solution, or organic remains or secretions of plants and animals.

Shale oil. - Oil that is extracted from oil shale and normally requires reaction with hydrogen for conventional uses associated with crude oil.

Solute-transport model. - The mathematical description of a hydrologic system, including dissolved constituents in the ground and surface water. Used to simulate and study the relations between the flow system and the dissolved constituents under various conditions.

Spoil pile. - The dump where mine-waste materials are disposed of or piled.

Strike. - The directional trend of a horizontal line in the plane of an inclined geologic bed, joint, fault, or structural plane. Used in conjunction with the term, dip, to describe a spatial orientation.

Structural basin.-A downwarped or faulted zone in the Earth's crust resulting from large-scale movement and in which sediments have accumulated.

Sublimation. - The change in state of a solid to a gas or vice versa, without becoming a liquid.

Subsidence. - The settling of the Earth's surface because of solution action, compaction, mining, withdrawal of water, crustal warping, or other cause.

Surface mining. - Mining in surface excavations, such as an open pit or strip mine. 
Surface runoff. - That part of the precipitation which travels over the soil surface to the nearest stream channel.

Tectonic. - A geologic term referring to the structural and deformational characteristics of a large region.

Titration. - A chemical method for determining the amount of a constituent in a solution by adding a reagent of known concentration to the solution and observing the added volume required to convert the constituent to some other form.

Trap. - A barrier that impedes the upward migration of oil and (or) gas and allows either to accumulate. A stratigraphic trap may result where a rock unit of low permeability forms a barrier; a structural trap may result from a barrier of low permeability that is created by folding, faulting, or other deformation.

Turbidity current. - A sediment-laden water current that flows by gravity down the slope and along the bottom of a lake or sea. Such currents can transport large volumes of sediment from the shore to the deepest parts of a lake in a short time, measured in hours or a few days. Possibly as much as one-half of the Colorado oil-shale deposits in the deeper part of the Piceance basin were deposited by such flows.

Unconformity. - A large gap in the geologic record that is indicated by missing rock units in the stratigraphic succession. The missing units either never were deposited or were deposited and subsequently removed by erosion.

Undergound mining. - Mining in underground excavations, such as room-and-pillar mining.

Valley-fill alluvial aquifer. - A saturated alluvial deposit of sand and gravel that underlies and normally is hydraulically connected to an overlying stream.

Water right. - An order issued by a specific State court, validating an appropriation of water, and establishing a priority for that water use.

Watershed model. - A mathematical description of a watershed, used to simulate and study the behavior of the watershed, under existing, hypothetical, or proposed conditions. 




\title{
INTRODUCTION
}

\author{
BY O. JAMES TAYLOR
}

\section{THIS REPORT DESCRIBES THE OIL SHALE, ASSOCIATED MINERALS, WATER RESOURCES, AND OTHER MINERALS OF THE PICEANCE BASIN AND THE POSSIBLE IMPACTS OF OIL-SHALE DEVELOPMENT}

The Piceance (pee'ahnce) basin, Colorado, contains enormous resources of shale oil, as illustrated on the cover of this paper. Several regions in the world have resources of shale oil (shown in brown) that are much larger than the known reserves of crude oil (shown in tan). The Piceance basin, which contains 1,200 billion barrels of shale oil, is the largest single shale-oil resource known. It has the potential to supplement the energy and petrochemical supply of our Nation for centuries.

The purposes of the report are:

1. To inform planners and managers of the occurrence, abundance, and variety of materials that occur in the Piceance basin;

2. To describe the geology and hydrology of the basin as they relate to mineral occurrence and development (in this report development refers to mineral extraction, processing, and transportation); and

3 . To assess the requirements, benefits, and impacts of different levels of mineral development.

This report provides information for planners, managers, legislators, and others who have some technical knowledge of the subjects discussed; however, the social and economic aspects of oil-shale development are beyond its scope and are not included.

This report is designed to give the reader a general understanding of the natural processes that formed the Piceance basin as well as its rocks, minerals, and water resources. By studying these processes, the reader will be able to understand the present configuration of the basin. Mineral development is discussed to provide the reader with an awareness of the uncertainties, requirements, benefits, and effects of various types of development.

The Piceance basin, as described in this report, lies between the White and the Colorado Rivers in northwestern Colorado. The basin extends about 55 miles in the northsouth direction and about 35 miles in the east-west direction. The total area of the basin is about 1,600 square miles.
Land-surface altitudes range from about 5,600 feet along the north rim of the basin to about 9,400 feet in the south. The topography is varied and includes flood plains, rolling hills, steep cliffs, and deeply incised canyons.

The first part of this report focuses on the depositional and structural activity that formed the basin and its minerals. In addition to oil shale, the basin contains billions of tons of the important associated minerals nahcolite and dawsonite, as well as natural gas, crude oil, and coal.

Development of the oil shale will require extensive mining, mine drainage, and construction of retorts. In addition, large water supplies are needed for various aspects of oilshale development and associated activities. Ore transportation, waste disposal, and land reclamation complete the development phase. The expected components of oil-shale development are discussed to indicate the changes in the basin that may result from development.

The report further describes the principal features of the hydrologic system in Piceance basin. This basin is drained by Piceance, Yellow, Parachute, and Roan Creeks. Eventually these creeks may furnish water supplies for mineral development. Ground water is contained in valley-fill alluvial aquifers and in the fractures and pores of the oilshale and overlying rocks. The oil shale and overlying rocks are bedrock aquifers that will need to be drained locally before and during oil-shale development. Water pumped from the mines probably also will supply water for this development. The streams and aquifers may be considered a single hydrologic system because they are hydraulically connected.

The general water quality in the basin also is examined. Studies of suspended sediment in Piceance Creek indicate a high erosion potential. The quality of water in aquifers is highly variable and needs to be considered in relation to mine drainage. Studies of aquatic insects in the creeks provide a method to assess the effects of suspended and dissolved constituents in stream water under natural and development conditions.

The geologic framework of the basin is considered. The maximum thickness of sedimentary rock that underlies the oil shale and associated minerals is about 25,000 feet. Several of the underlying formations may be aquifers that could furnish water for oil-shale development. However, these formations have not been tested for their water-supply potential. 


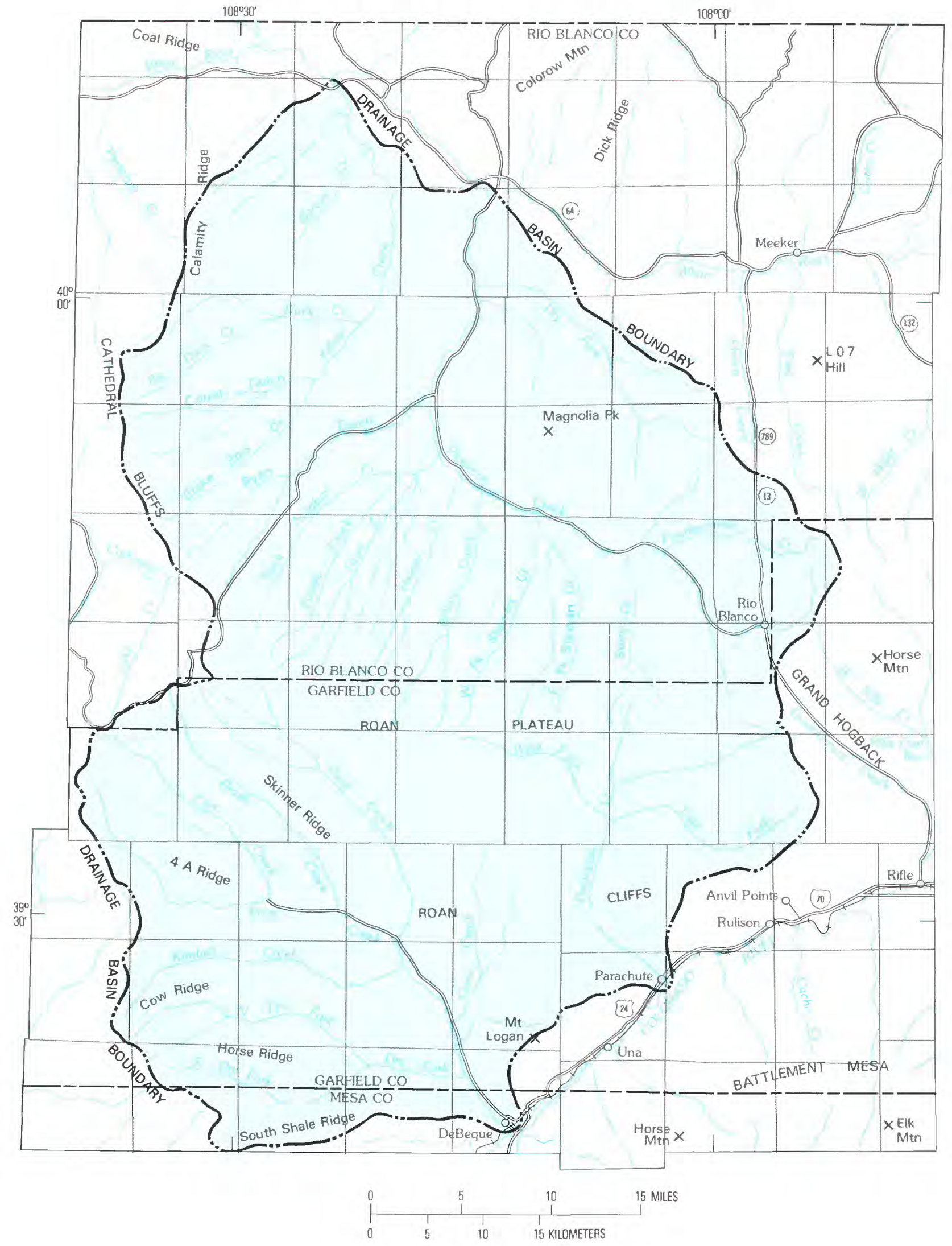

Location and extent of the Piceance basin (fig. 1). 
Several effects of oil-shale development may require careful monitoring and management. The large volumes of retorted shale resulting from oil-shale development may be leached of toxic materials or eroded. The in situ retorts may release a variety of wastes within the bedrock aquifers. Emissions from retorts to the atmosphere may degrade precipitation and lake water.

In the final chapter, three distinct levels of oil-shale development are compared. The relative benefits, water requirements, sources of water supply, and effects of development are estimated.

References are omitted from the text, and are listed at the end of each section.

\section{REFERENCES}

Donnell, J. R., 1976, Global oil-shale resources and costs, in Meyer, R. F., ed., The future supply of nature-made petroleum and gas, technical reports: New York, Pergamon Press, p. 843-856.

U.S. Department of Energy, 1978, International petroleum annual 1978: Energy Data Report DOE/EIA 0042(78), 35 p.

The discussions of the Piceance basin begin with descriptions of the general geology, Tertiary geologic history, the structural basin, and the geologic processes that have shaped the basin into its present form. An awareness of the geologic framework of the basin is fundamental to an understanding of its minerals and water resources. 

GEOLOGY, MINERALS, AND MINERAL DEVELOPMENT 



\title{
GENERAL GEOLOGY OF THE PICEANCE BASIN
}

\author{
BY MARJORIE E. MACLACHLAN
}

\section{THE PICEANCE BASIN INCLUDES A STRUCTURAL AND DEPOSITIONAL BASIN AND SEVERAL DRAINAGE BASINS}

The Piceance basin is an area in northwestern Colorado named for Piceance Creek, a major tributary of the White River. (See map, fig. 3.) The basin is a structural, depositional, and drainage feature, and its boundaries differ, depending on which aspect is under consideration.

The structural basin is a geologically downwarped region surrounded by uplifted regions, as shown below, including the Axial Basin arch, the Grand Hogback, the White River uplift, the Gunnison uplift, the Uncompahgre uplift, the Douglas Creek arch, and the Yampa plateau. Basins and uplifts are common in the Rocky Mountain region.
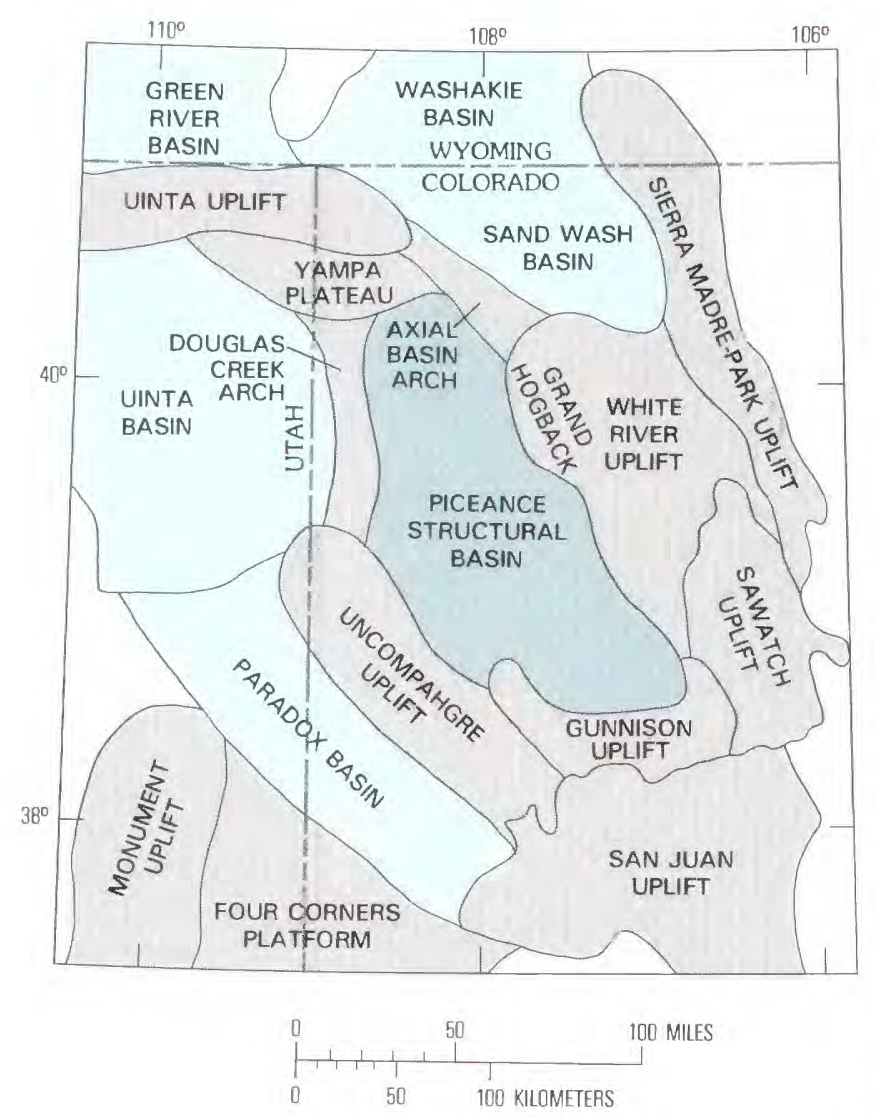

Structural basins and uplifts (fig. 2).
The downwarped region is a depositional basin, filled with eroded sediments that have been consolidated to form sedimentary rock. Some investigators use the term Piceance Creek basin to describe the part of the structural and depositional basin that lies between the Colorado River on the south, the White River on the north, the Douglas Creek arch on the west, and the Grand Hogback on the east.

Stream systems drain water from precipitation into stream channels in the downwarped region between the Colorado and the White Rivers. Four major drainage basins have developed: Piceance and Yellow Creeks drain to the north, and Roan and Parachute Creeks drain to the south. Drainage basins are named after the principal creek within them, as shown below.

In this report, for convenience and simplicity, the Piceance basin refers to the part of the structural, depositional, and four major drainage basins that lie between the Colorado and the White Rivers. This is the region of great mineral concentration in which preliminary mineral development has begun, and it is the principal region that will be affected by future development.

\section{STUDIES OF EXPOSED FORMATIONS, WELL DRILLERS' RECORDS, AND ROCK SAMPLES ARE USED TO DETERMINE THE ORIGIN AND AGE OF ROCKS AND TO SEARCH FOR INCLUDED MINERALS}

Geologists collect information on bedrock in the Piceance basin by examining rocks where they are exposed, by studying the descriptions of subsurface rocks recorded by well drillers, and by examining and analyzing rock samples. This information allows them to identify the geologic processes that formed the rock and to estimate the geologic age during which the rock was deposited. The same information is used to group the rocks into formations that were deposited under similar conditions. By reconstructing the geologic history of the region, favorable sites can be selected to explore for minerals and ground-water reservoirs.

Rocks discussed in this report were deposited in the Piceance basin as much as hundreds of millions of years ago. 
OIL SHALE, WATER RESOURCES, VALUABLE MINERALS, PICEANCE BASIN, COLO.

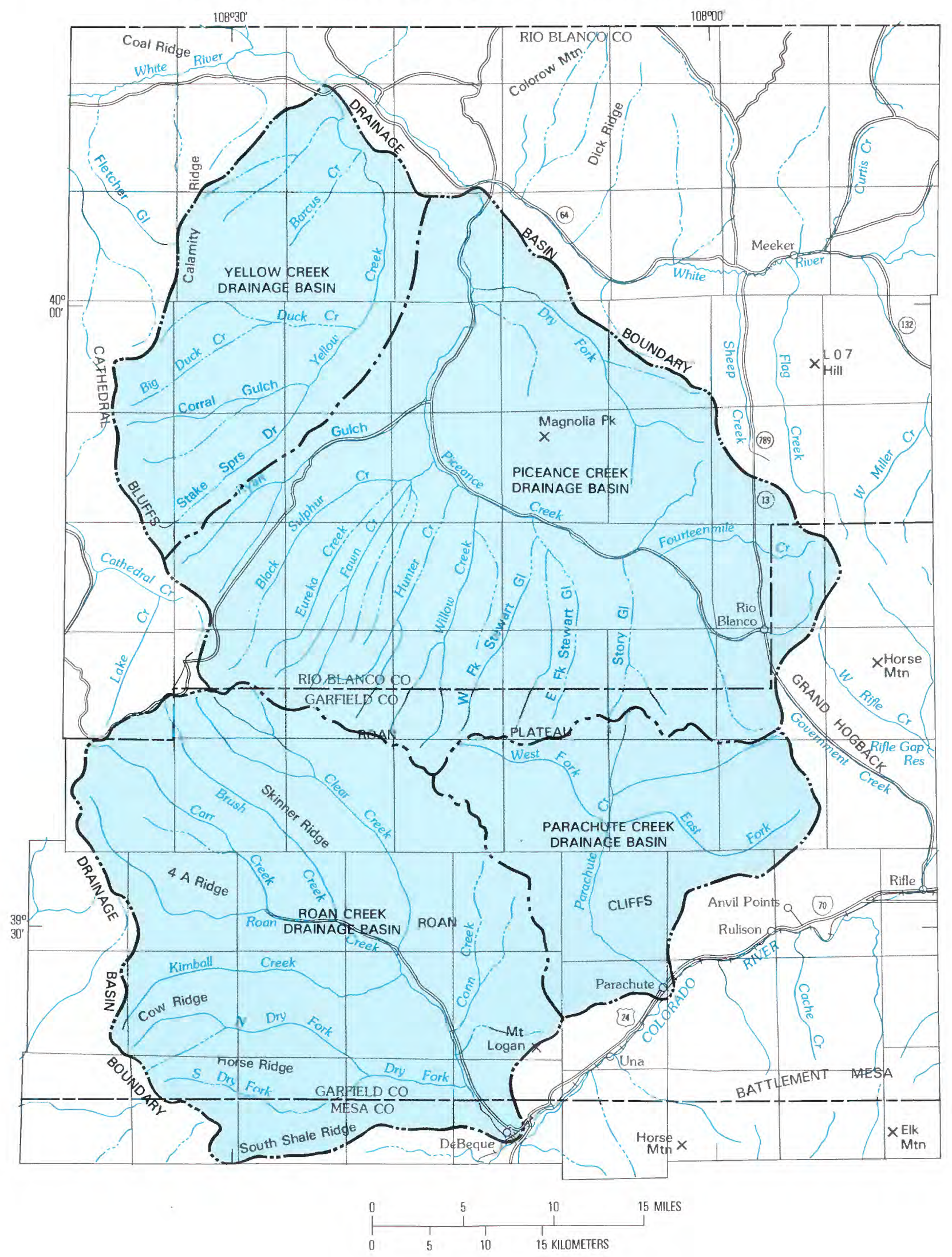

Major drainage basins (fig. 3). 
For purposes of discussion, the rocks have been subdivided into three age groups shown on the geologic map:

1. Precambrian,

2. Paleozoic and Mesozoic, and

3. Tertiary.

The Precambrian rocks are the oldest age group and are discussed only briefly. The Paleozoic and Mesozoic rocks contain minerals and water and can be studied directly where they are exposed on the margins of the basin. The characteristics and distribution of Paleozoic and Mesozoic rocks at depth below the surface in the basin have been interpreted from studies of the exposed rocks and well drillers' records. The rocks of the Paleozoic and Mesozoic Eras are discussed in greater detail in the chapter "Paleozoic and Mesozoic formations and their potential as ground-water reservoirs." Tertiary rocks are the youngest age group and are exposed over much of the basin. Oil shale, nahcolite, dawsonite, and ground water occur in sedimentary rocks of Tertiary age. Tertiary volcanic rocks are found at scattered localities to the south and east.

The geologic time scale indicates the time during which the various geologic formations were deposited. All rocks older than 570 million years are Precambrian, by definition. Precambrian rocks from 950 million to 1.8 billion years old are found in the Piceance basin. The Paleozoic Era lasted 330 million years, and the Mesozoic Era lasted about 177 million years. The Tertiary Period of the Cenozoic Era followed, lasted 61 million years, and ended 2 million years ago. The Piceance structural basin formed, mostly during the Tertiary Period, from Late Cretaceous into Eocene time. The Quaternary Period of the Cenozoic Era is of relatively short duration, spanning the last 2 million years. The other periods and epochs are of very different durations, as indicated in the geologic time scale.

The Tertiary rocks are discussed first because they contain the oil shale, major mineral deposits, and important ground-water resources. Representative formations of Tertiary age are shown in the stratigraphic column. Paleocene and Eocene sedimentary rocks are exposed in a large area between the Colorado and the White Rivers. Isolated exposures of Paleocene and Eocene rocks also are found south of the Colorado River. The Oligocene is represented only by igneous intrusive rocks in the West Elk Mountains at the southeast end of the structural basin. Volcanic rocks erupted on Grand Mesa, due east of Grand Junction, during the Miocene Epoch about 9 million years ago. No Pliocene rocks have been identified.

Tertiary sedimentary rocks are divided into four principal formations. The oldest are the Fort Union and Wasatch Formations of Paleocene age, which contain natural gas. The Fort Union Formation is exposed in a narrow band on the northeast side of the basin, extending from near the town of Meeker northward to near the Axial Basin arch. The lower part of the Wasatch Formation is exposed in the southern part of the basin, and the upper part, of Eocene age, underlies the entire basin. Two younger Eocene units, the Green River and the Uinta Formations, occupy successively smaller areas in the basin. The Green River Formation contains the oil shale, nahcolite, dawsonite, ground water, natural gas, and crude oil. These four formations comprise a section of Tertiary rock that is probably more
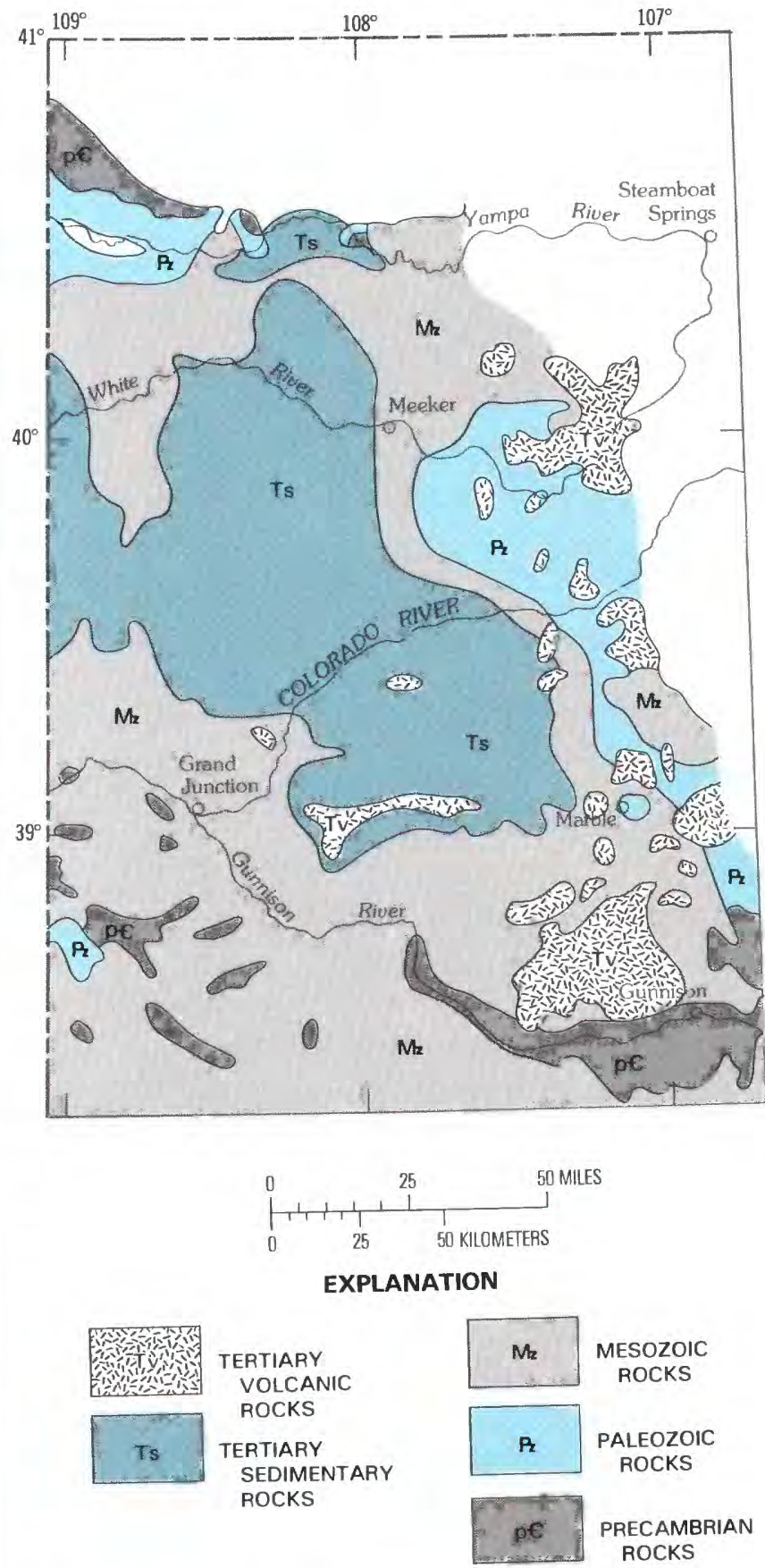

General geologic map of northwestern Colorado (fig. 4). 
TABLE 1.-Geologic time scale

\begin{tabular}{|c|c|c|c|c|}
\hline \multicolumn{3}{|c|}{ GEOLOGIC TIME SCALE } & \multirow{2}{*}{$\begin{array}{c}\text { ESTIMATED } \\
\text { AGE, IN } \\
\text { MILLIONS } \\
\text { OF YEARS } \\
\text { Present }\end{array}$} & \multirow{2}{*}{$\begin{array}{l}\text { DURATION, } \\
\text { IN } \\
\text { MILLIONS } \\
\text { OF YEARS }\end{array}$} \\
\hline \multirow{7}{*}{$\begin{array}{c}\text { Cenozoic } \\
\text { Era }\end{array}$} & \multirow{2}{*}{$\begin{array}{c}\text { Quaternary } \\
\text { Period }\end{array}$} & Holocene Epoch & & \\
\hline & & Pleistocene Epoch & & \\
\hline & \multirow{5}{*}{$\begin{array}{c}\text { Tertiary } \\
\text { Period }\end{array}$} & Pliocene Epoch & & 3 \\
\hline & & Miocene Epoch & & 19 \\
\hline & & Oligocene Epoch & -38 & 14 \\
\hline & & Eocene Epoch & & 17 \\
\hline & & Paleocene Epoch & & 8 \\
\hline \multirow{3}{*}{$\begin{array}{c}\text { Mesozoic } \\
\text { Era }\end{array}$} & \multicolumn{2}{|c|}{ Cretaceous Period } & & 75 \\
\hline & \multicolumn{2}{|c|}{ Jurassic Period } & -205 & 67 \\
\hline & \multicolumn{2}{|c|}{ Triassic Period } & & 35 \\
\hline \multirow{7}{*}{$\begin{array}{c}\text { Paleozoic } \\
\text { Era }\end{array}$} & \multicolumn{2}{|c|}{ Permian Period } & 29 & 50 \\
\hline & \multicolumn{2}{|c|}{ Pennsylvanian Period } & & 40 \\
\hline & \multicolumn{2}{|c|}{ Mississippian Period } & & 30 \\
\hline & \multicolumn{2}{|c|}{ Devonian Period } & 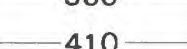 & 50 \\
\hline & \multicolumn{2}{|c|}{ Silurian Period } & & 25 \\
\hline & \multicolumn{2}{|c|}{ Ordovician Period } & & 65 \\
\hline & \multicolumn{2}{|c|}{ Cambrian Period } & -570 & 70 \\
\hline \multicolumn{3}{|c|}{ Precambrian } & & \\
\hline
\end{tabular}

than 11,000 feet thick. Sedimentary rocks younger than late Eocene have not been identified with certainty in the Piceance basin.

\section{THE STRUCTURAL BASIN WAS FORMED DURING THE LARAMIDE OROGENY}

Studies of the tectonic features of the region also provide information on the geologic history that relates to the occurrence of minerals and water. The Piceance structural basin was formed during the Laramide orogeny, a mountainbuilding process of thrusting, faulting, and folding. The orogeny lasted at least 10 million years from Late Cretaceous to Eocene time. The structural basin resulted from subsidence that accompanied the mountain building in adjacent regions. The structural basin also was a basin of deposition; erosion of some of the surrounding highlands furnished the sediments that comprise the rocks of late Cretaceous and Tertiary age. During and after deposition, these rocks were altered by continued subsidence, uplifting, folding, faulting, and jointing. In some formations the structural deformation increased rock permeability and formed aquifers.
The regions surrounding the structural basin were uplifted at different times. The Douglas Creek arch is recognized as the oldest boundary structure because the Mesaverde Group of Late Cretaceous age and the Wasatch Formation of Eocene age thin toward and over the arch. This thinning indicates that the arch was present when the formations were being deposited. The Uinta and Uncompahgre areas were uplifted in Late Cretaceous age somewhat later than the Douglas Creek arch. The Axial Basin arch rose during early and middle Eocene time and formed a barrier between two ancient lakes while the Green River Formation and the large associated mineral resources were deposited. One lake was south of the arch in the Piceance basin, and the other was north of the arch. If the Axial Basin arch had not existed to separate the two ancient lakes, a single lake would have formed and the present distribution and grade of oil shale, nahcolite, and dawsonite undoubtedly would be different. The White River uplift is the youngest boundary structure.

The tremendous effect of the Laramide orogeny on the geologic formations in northwestern Colorado is evident in the structural relief in Precambrian rocks. The top of the subsurface Precambrian rocks near the Axial Basin arch is 18,000 feet below sea level; in contrast, the top of the 


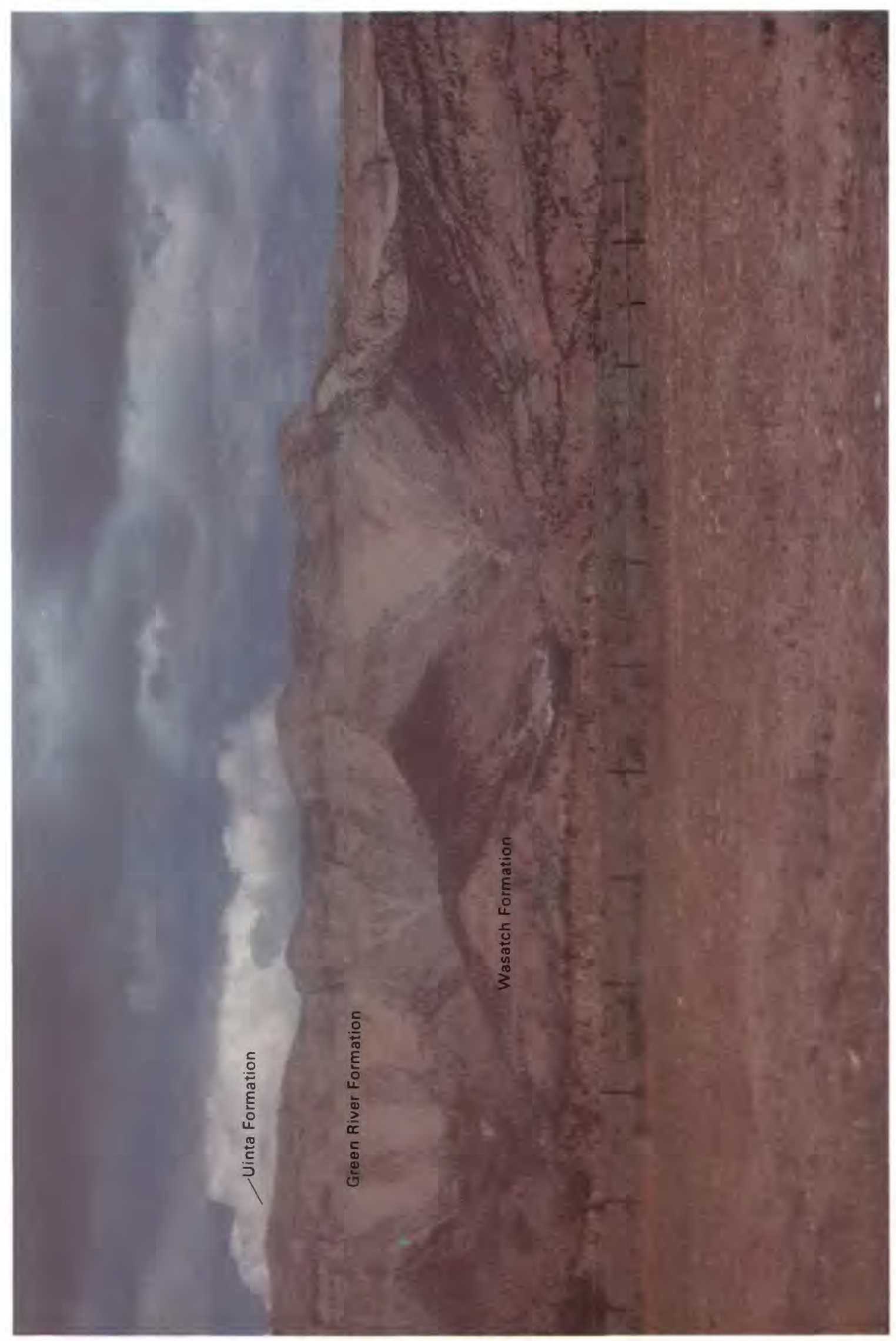

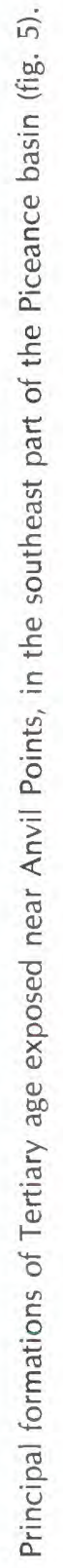


TABLE 2.-Stratigraphic column of Tertiary rocks between the Colorado and White Rivers ${ }^{1}$

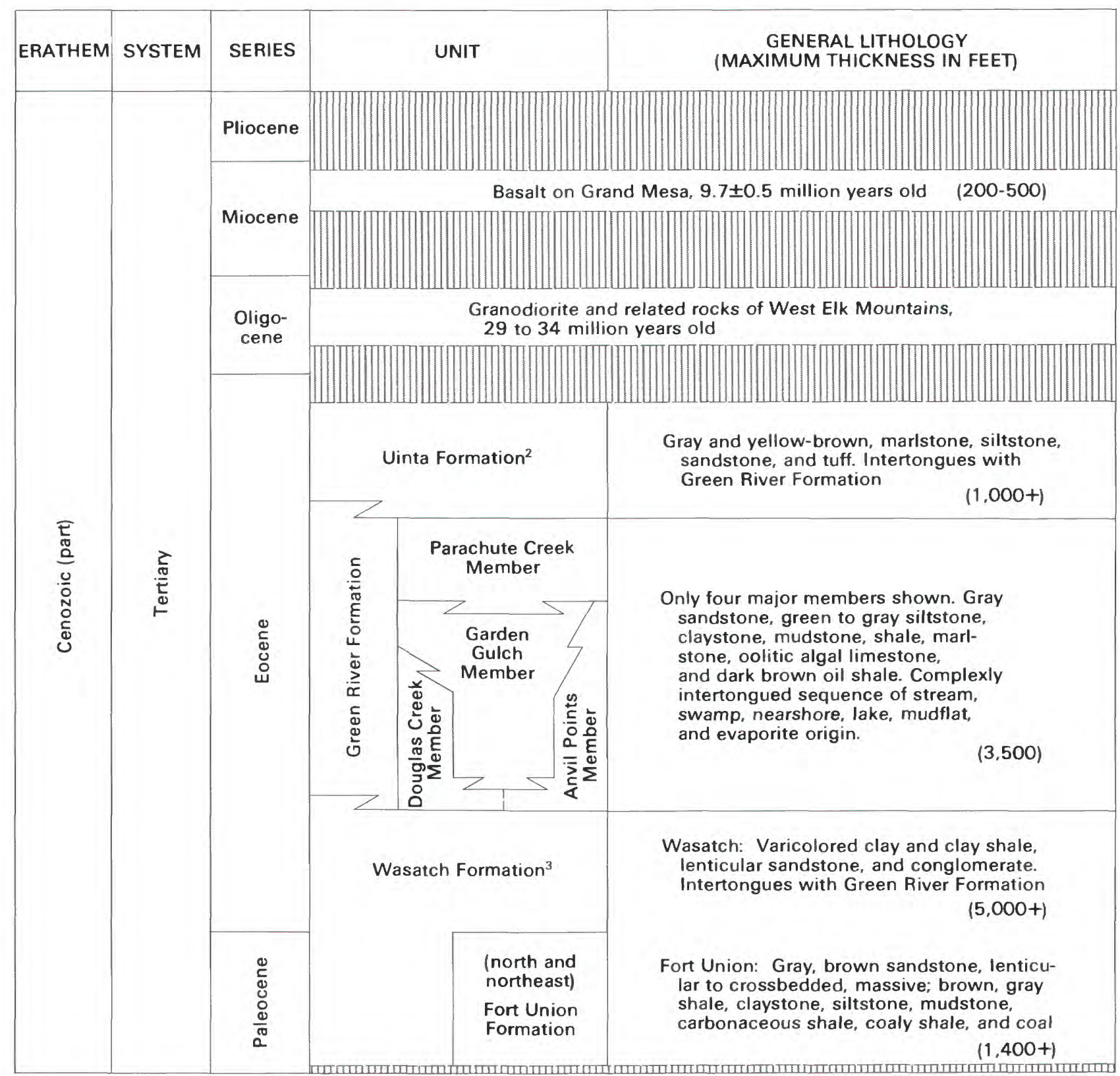

1Sources of information: Donnell, 1962; Hail, 1974; Pipiringos and Johnson, 1976; Pipiringos and Rosenlund, 1977; Roehler, 1974; Tweto, 1975; Tweto, 1976; Tweto, Moench and Reed, 1978.

${ }^{2}$ Cashion and Donnell (1974) extended the name Uinta Formation into the basin. The term Uinta replaced the use of the term Evacuation Creek Member of the Green River Formation, which was abandoned by them.

${ }^{3}$ Previous workers called a sandstone and conglomerate between the Wasatch and the Mesaverde, the Paleocene Ohio Creek Formation. This formation often was mapped with the Wasatch or Fort Union Formation. Johnson and May (1980) have reassigned the Ohio Creek as a member of the Upper Cretaceous Hunter Canyon Formation of the Mesaverde Group.

exposed Precambrian rocks on the adjacent uplifts is several thousand feet above sea level. In the White River uplift, the top of the Precambrian rocks is 28,000 feet higher than the top of those in the deepest part of the Piceance structural basin. In the Uinta uplift the difference in altitude is 26,500 feet; in the Uncompahgre uplift the difference in altitude is 27,000 feet. Because of the structural relief, formations that are exposed or at shallow depths in uplifted regions may lie at depths of tens of thousands of feet in the Piceance basin. 


\section{MAJOR PHYSICAL AND STRUCTURAL FEATURES OF THE BASIN \\ CAN BE STUDIED ON LANDSAT IMAGES}

Satellite remote sensing, in the form of Landsat imagery, provides a broad summary view of numerous, detailed features of Earth's surface. The Landsat image is obtained by recording the variations in reflected solar energy and enhancing the contrast in these variations to form a falsecolor image. On the Landsat image of the Piceance basin, most of the red-orange zones represent irrigated cropland, the brown zones indicate native trees and bushes, and the blue-gray zones are land areas that have little or no vegetation.

The streams and tributaries are prominent on the Landsat image because the irrigated land along their flood plains and the relief of the land surface along streams provide a strong contrast. The great relief of the incised valleys of Roan and Parachute Creek basins is striking in comparison to the slight relief in the Yellow and Piceance Creek basins.

Structural features are identified by their relief, effects on surface drainage, and color. The Piceance Creek Dome is identified easily by the radial pattern of its tributaries. A major lineament extends from the area drained by Parachute Creek into the White River uplift, as indicated by the dark color. Parachute Creek and tributaries of Piceance Creek and Dry Fork form an alinement that may be a structural feature. Several faults also are recognized by their relief and their effects on surface drainage.

\section{REFERENCES}

Bass, N. W., and Northrup, S. A., 1963, Geology of Glenwood Springs quadrangle and vicinity, northwestern Colorado: U.S. Geological Survey Bulletin 1142-J, 74 p.

Bradley, W. H., 1931, Origin and microfossils of the oil shale of the Green River Formation of Colorado and Utah: U.S. Geological Survey Professional Paper 168, $58 \mathrm{p}$.

Bryant, Bruce, 1979, Geology of the Aspen 15-minute quadrangle, Pitkin and Gunnison Counties, Colorado: U.S. Geological Survey Professional Paper 1073, $46 \mathrm{p}$.

Cashion, W. B., compiler, 1973, Geologic and structure map of the Grand Junction quadrangle, Colorado and Utah: U.S. Geological Survey Miscellaneous Investigations Map I-736.

Cashion, W. B., and Donnell, J. R., 1974, Revision of nomenclature of the upper part of the Green River Formation, Piceance Creek Basin, Colorado, and eastern Uinta Basin, Utah: U.S. Geological Survey Bulletin 1394-G, 9 p.

Donnell, J. R., 1962, Tertiary geology and oil-shale resources of the Piceance Creek basin between the Colorado and White Rivers, northwestern Colorado: U.S. Geological Survey Bulletin 1082-L, p. 835-891.

Gaskill, D. L., and Godwin, L. H., 1966, Geologic map of the Marble quadrangle, Gunnison and Pitkin Counties, Colorado: U.S. Geological Survey Geologic Quadrangle Map GQ-512.

Grose, L. T., 1972, Tectonics in Geologic Atlas of the Rocky Mountain region: Denver, A. B. Hirschfeld Press, p. 35-44.

Hail, W. J., Jr., 1974, Geologic map of the Rough Gulch quadrangle, Rio Blanco and Moffat Counties, Colorado: U.S. Geological Survey Geologic Quadrangle Map GQ-1195.

Hansen, W. R., 1965, Geology of the Flaming Gorge area, Utah-ColoradoWyoming: U.S. Geological Survey Professional Paper 490, 196 p.

Hansen, W. R., and Carrara, P. E., 1980, Geologic map of the Tanks Peak quadrangle, Moffat County, Colorado: U.S. Geological Survey Geologic Quadrangle Map GQ-1534.

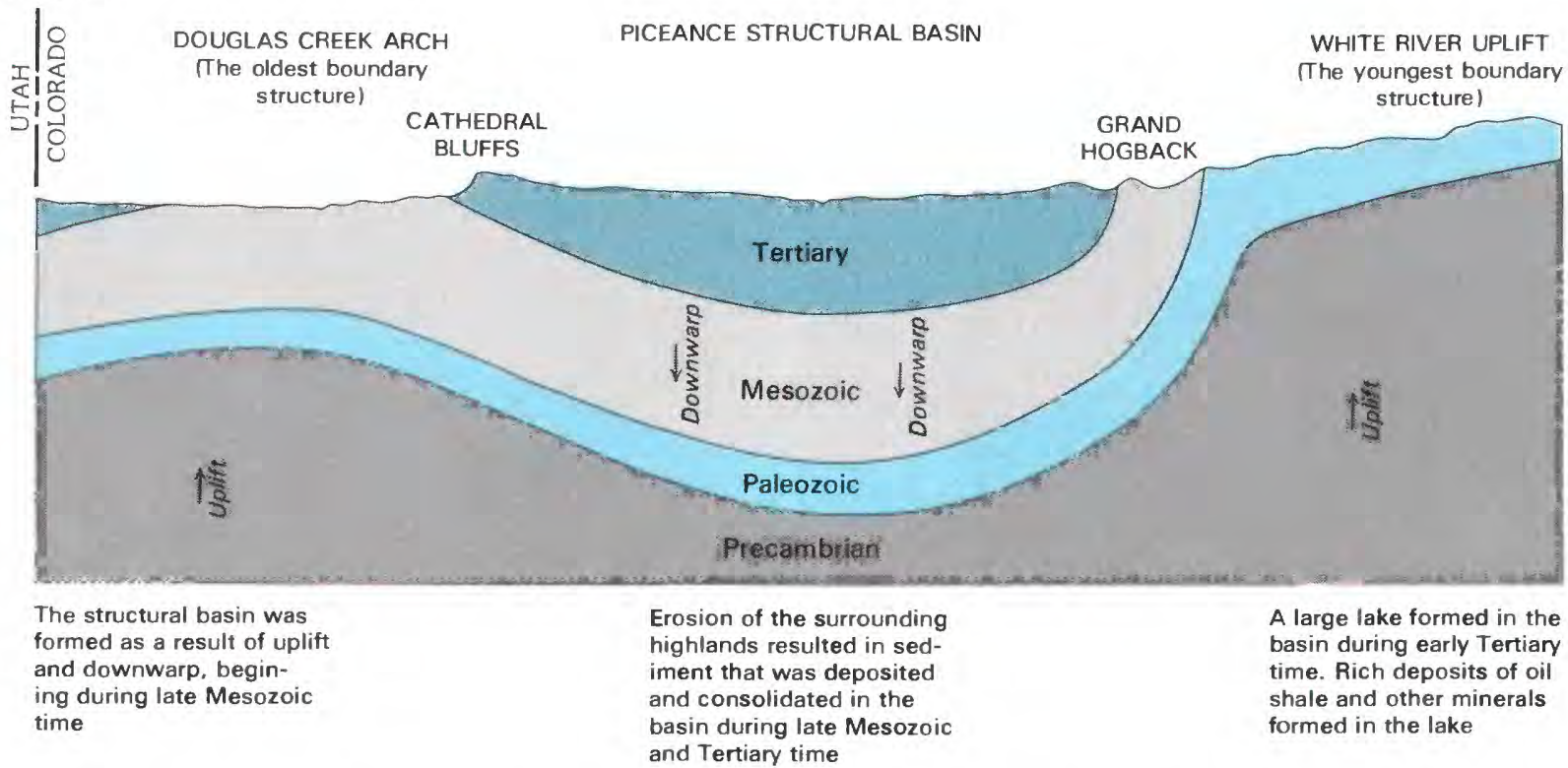

Diagrammatic east-west cross section, northwestern Colorado (fig. 6). 

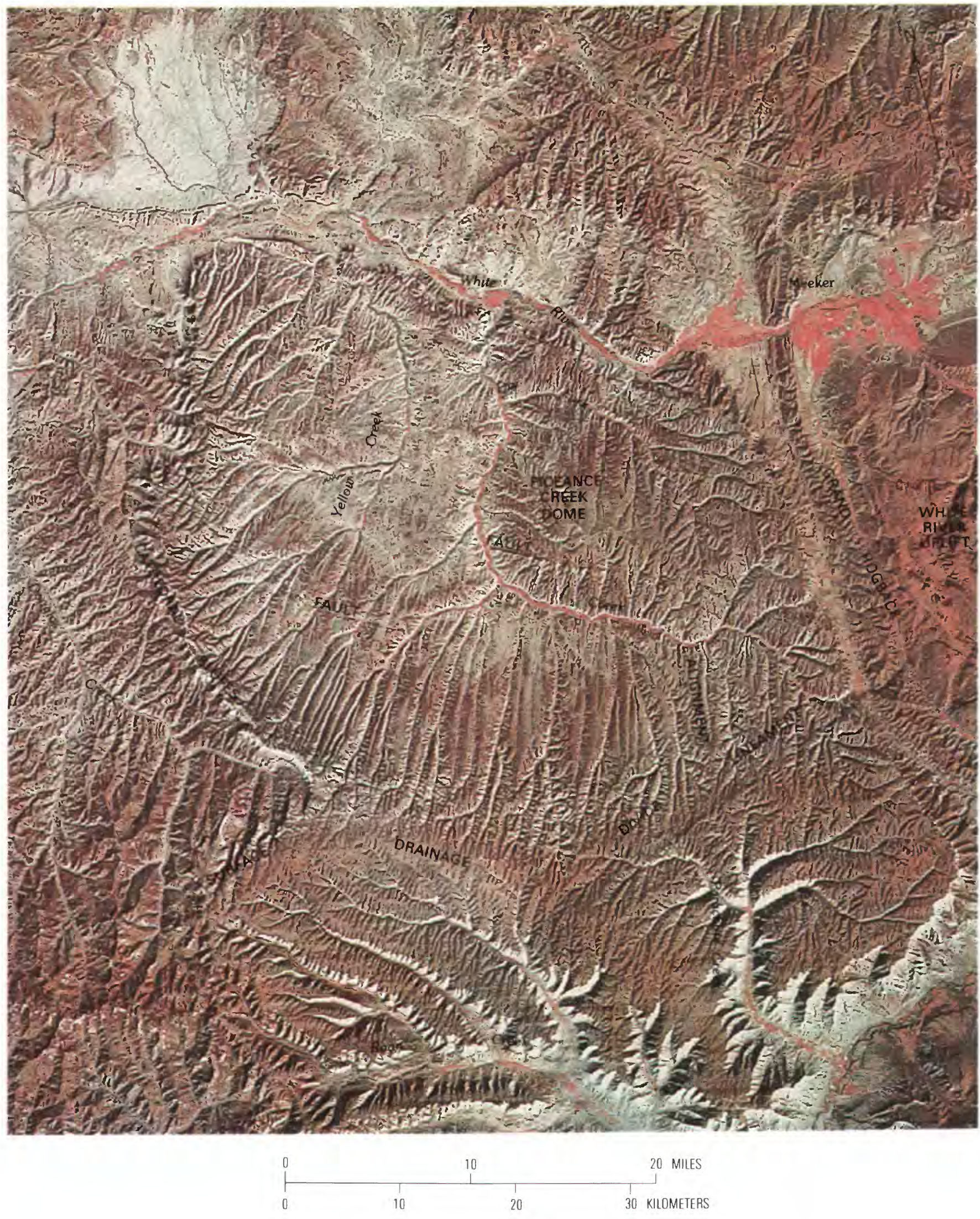

Landsat image of Piceance basin and surrounding areas (fig. 7). 
Johnson, R. C., and May, Fred, 1980, A study of the Cretaceous-Tertiary unconformity in the Piceance Creek basin, Colorado-The underlying Ohio Creek Formation (Upper Cretaceous) redefined as a member of the Hunter Canyon or Mesaverde Formation: U.S. Geological Survey Bulletin 1482-B, 27 p.

King, P. B., and Beikman, H. M., compilers, 1974, Geologic map of the United States: U.S. Geological Survey, scale 1:2,500,000.

Murray, F. N., 1966, Stratigraphy and structural geology of the Grand Hogback Monocline, Colorado: Boulder, University of Colorado, Ph. D. thesis, 219 p.

Pipiringos, G. N., and Johnson, R. C., 1976, Preliminary geologic map and correlation diagram, White River City quadrangle, Colorado: U.S. Geological Survey Miscellaneous Field Studies Map MF-736.

Pipiringos, G. N., and Rosenlund, G. C., 1977, Geologic map of the White Rock quadrangle, Colorado: U.S. Geological Survey Miscellaneous Field Studies Map MF-837.
Roehler, H. W., 1974, Depositional environments of rocks in the Piceance Creek Basin, Colorado: Rocky Mountain Association of Geologists, Guidebook No. 25, Guidebook to the energy resources of the Piceance Creek Basin, Colorado, p. 57-64.

Rowley, P. D., and Hansen, W. R., 1979, Geologic map of the Plug Hat Rock quadrangle, Moffat County, Colorado: U.S. Geological Survey Geologic Quadrangle Map GQ-1514.

Tweto, Ogden, compiler, 1976, Geologic map of the Craig $1^{\circ} \times 2^{\circ}$ quadrangle, northwestern Colorado: U.S. Geological Survey Miscellaneous Investigations Map I-972.

Tweto, Ogden, Moench, R. H., and Reed, J. C., Jr., 1978, Geologic map of the Leadville $1^{\circ} \times 2^{\circ}$ quadrangle, northeastern Colorado: U.S. Geological Survey Miscellaneous Investigations Map I-999.

The minerals nahcolite, dawsonite, and halite occur with the oil shale because they formed together in ancient lakes. A description of the depositional conditions follows. 



\title{
THE ORIGIN OF OIL SHALE AND ASSOCIATED MINERALS
}

\author{
By JOHN R. DYNI
}

\section{OIL SHALE, NAHCOLITE, AND DAWSONITE WERE FORMED IN ANCIENT LAKES}

About 48 million years ago, during the Eocene Epoch, several large lakes covered thousands of square miles in parts of Wyoming, Utah, and Colorado. Two of these lakes have been named Lake Uinta and Lake Gosiute. Lake Uinta occupied two large structural basins in northeastern Utah and northwestern Colorado. At its maximum size, Lake Uinta covered about 22,000 square miles, about the size of Lake Michigan, and extended about 190 miles from east to west, and as much as $\mathbf{1 1 0}$ miles from north to south. Lake Gosiute occupied a structural basin in southwestern Wyoming and covered about 15,500 square miles.

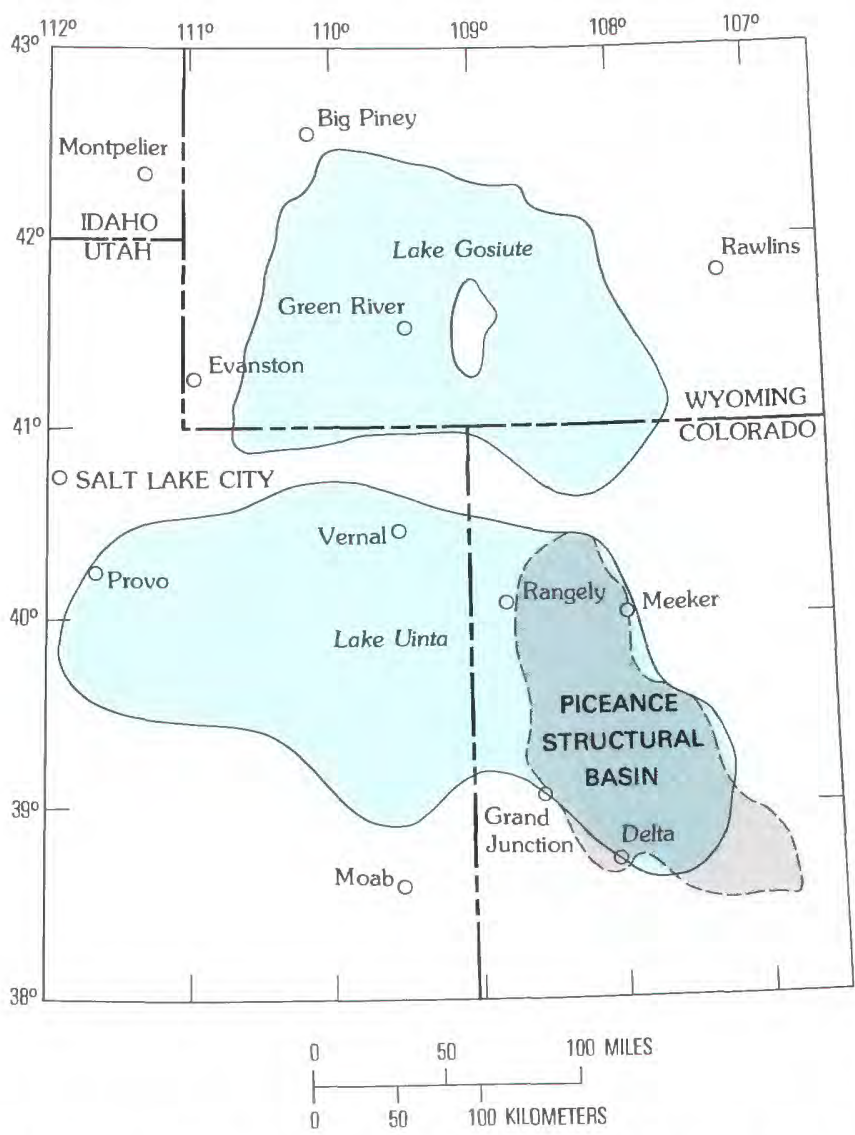

Maximum extent of ancient Lakes Uinta and Gosiute during Eocene time (fig. 8).
Vast quantities of oil shale accumulated as organic-rich marls in the deeper parts of the lakes. These marls, which are hundreds of feet thick, accumulated in the eastern part of Lake Uinta (Piceance basin in Colorado).

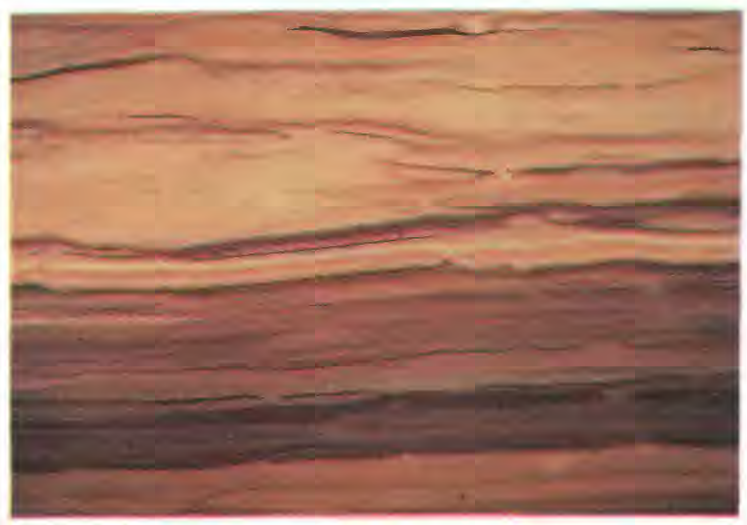

Polished slab of siltstone (light tan) and medium- to high-grade oil shale (brown to dark brown) from the Mahogany zone (fig. 9).

Other potentially valuable minerals are abundant in the oil-shale deposits. Nahcolite, a sodium bicarbonate mineral; dawsonite, a sodium aluminum carbonate mineral; and halite, sodium chloride (common table salt) are interspersed through the lower part of the oil-shale deposits.

Nahcolite is a potential source of soda ash, which is used in the manufacture of glass and many industrial chemical products. A promising new use for nahcolite is in removing sulfur dioxide, an environmentally harmful chemical, from industrial stack gases such as those produced by coal-fired electric-generating plants. Dawsonite is a source of aluminum that can be coproduced with the shale oil. In the Piceance basin, the resources of nahcolite are estimated to be 32 billion tons and dawsonite resources are estimated to be 19 billion tons, or 6.5 billion tons of alumina. 


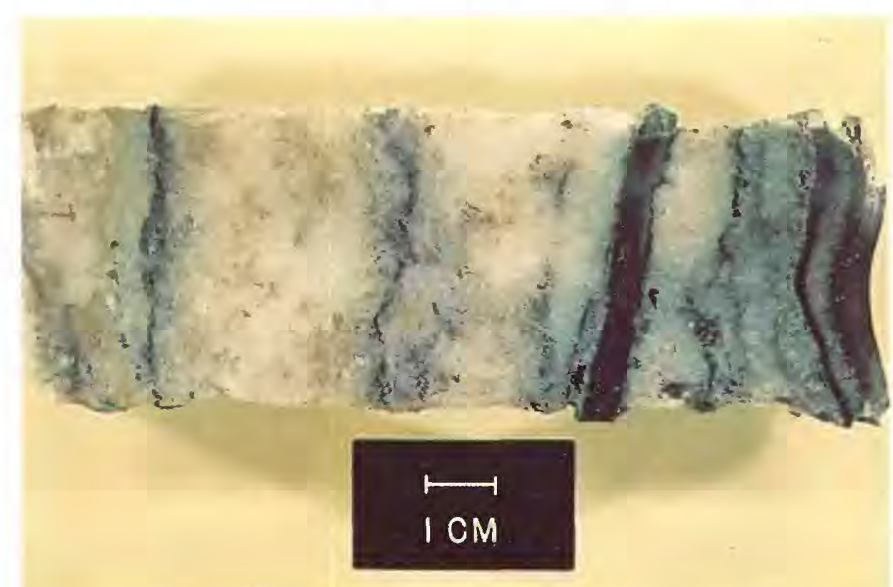

Drill core of interbedded coarse crystalline white nahcolite with dark-colored oil-shale layers (fig. 10).

\section{KEROGEN PROBABLY RESULTED FROM THE DECOMPOSITION OF ALGAE AND BACTERIA IN ANCIENT LAKES}

Kerogen, the organic matter in oil shale, is a fine-grained substance composed of carbon, hydrogen, nitrogen, and oxygen; its complete chemical structure is unknown. When heated to $900^{\circ} \mathrm{F}$, the kerogen decomposes and yields a synthetic crude oil that can be refined to obtain gasoline, fuel oils, and lubricants.

Kerogen gives few physical clues of its origin, but most likely it represents the decomposition products of microscopic algae and bacteria that once thrived in the nutrientrich waters of Lake Uinta. Because the deeper waters and sediments of the lake were devoid of oxygen, the environment was not habitable for lake-bottom scavengers and burrowing aquatic animals. Thus, the algae and bacterial detritus were not consumed by higher forms of life, but were buried with the sediments and eventually solidified to form oil shale.

\section{STREAMS CARRIED SEDIMENT AND SALTS INTO LAKE UINTA}

The lake sediments and various soluble salts were derived from sedimentary rocks exposed in the drainage basin of Lake Uinta, which encompassed a large area in western Colorado and parts of Utah, Arizona, and New Mexico. The sediments and salts were carried by streams to the lake. The coarser sandy materials were deposited in deltas where the streams emptied into Lake Uinta and in fringing shallowwater mudflats and sandy bars. The finer-sized silts and clays were swept to the deeper parts of the lake by bottom and surface currents.

\section{THE ANCIENT LAKES RESPONDED TO CLIMATIC AND GEOLOGIC CHANGES}

During its existence, the depth and extent of Lake Uinta changed greatly in depth and size in response to moist and dry rimatic cycles. Some researchers believe Lake Uinta was a shallow lake that frequently became dry, whereas others believe the lake was a deep and permanent body of water. During dry periods, the lake area decreased and soluble salts of sodium carbonate and chloride were concentrated in the deepest part of the lake, chiefly in the northern part of the Piceance basin. The lake water became incorporated in the organic marls that were accumulating in the deeper parts of the lake. Much nahcolite precipitated within the soft marls as scattered clumps of crystals, which commonly are several inches across. With further evaporation, the lake water became supersaturated with sodium bicarbonate-and eventually with sodium chloride-and beds of nahcolite and halite precipitated.

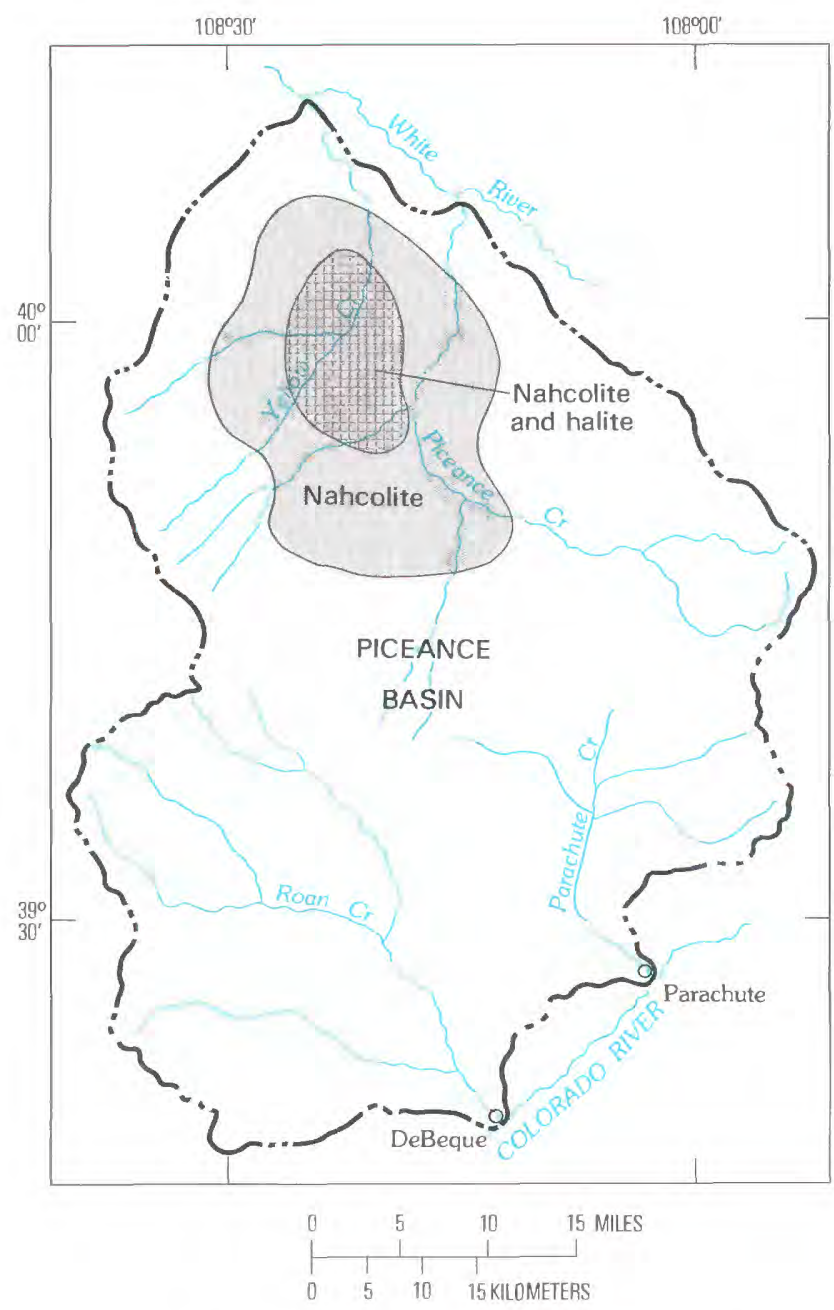

Nahcolite and halite deposited in the deep parts of Lake Uinta during dry climatic periods (fig. 11). 

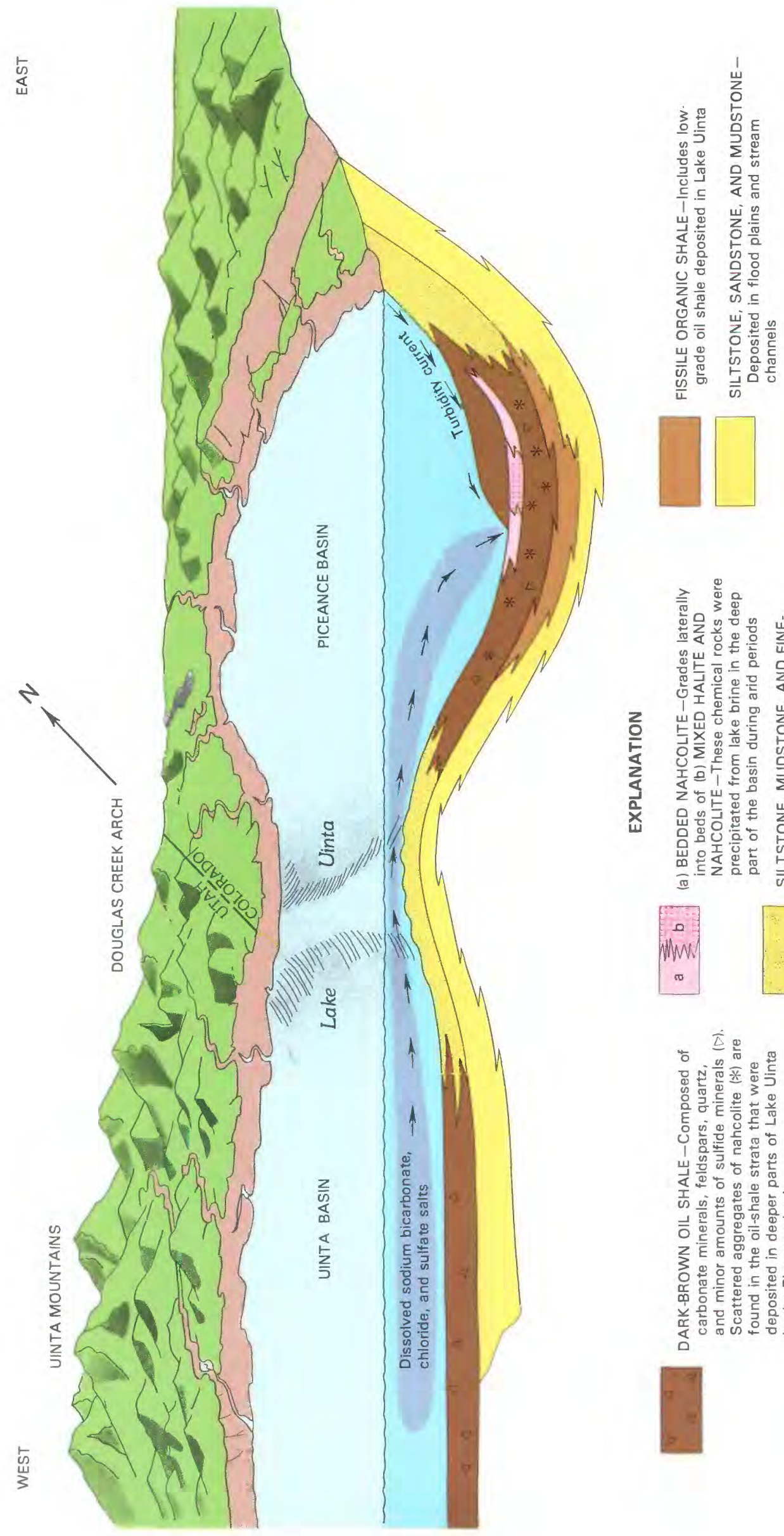

$\dot{\widehat{\Xi}}$

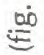

$\stackrel{\text { : }}{5}$

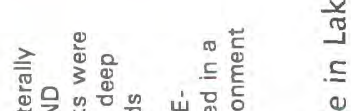

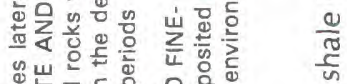

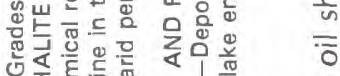

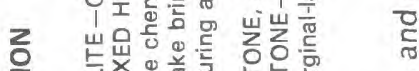

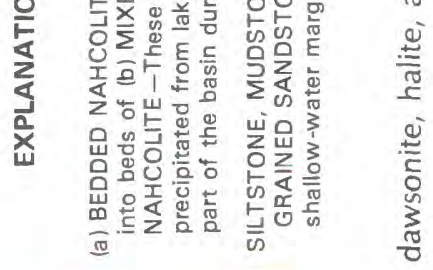

Whin:

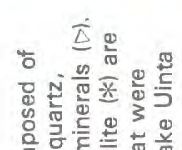

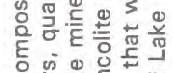

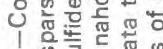

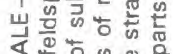

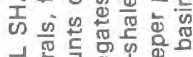

के

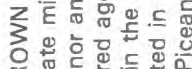

采

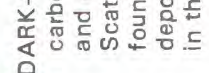

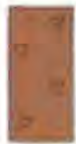




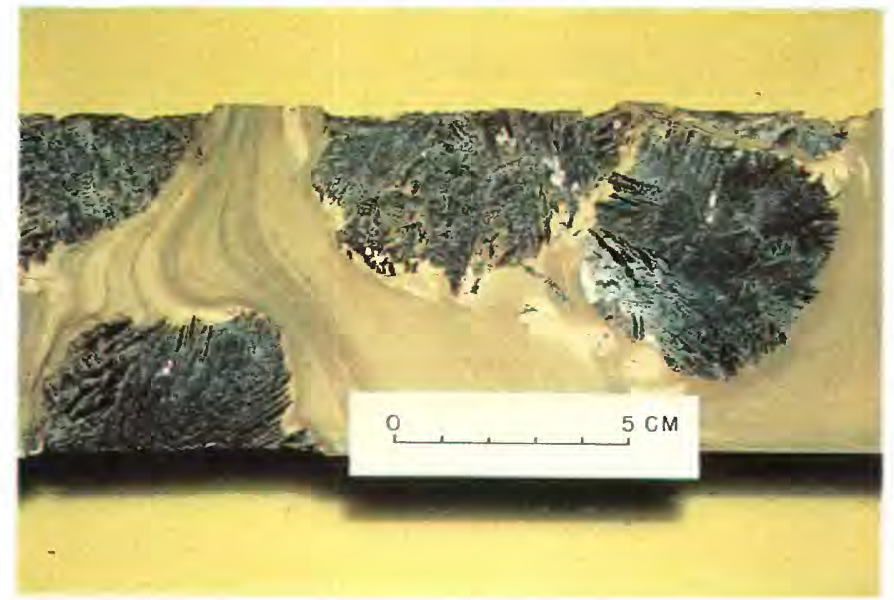

Drill core showing coarse crystalline scattered aggregates of nahcolite in high-grade oil shale (fig. 13).

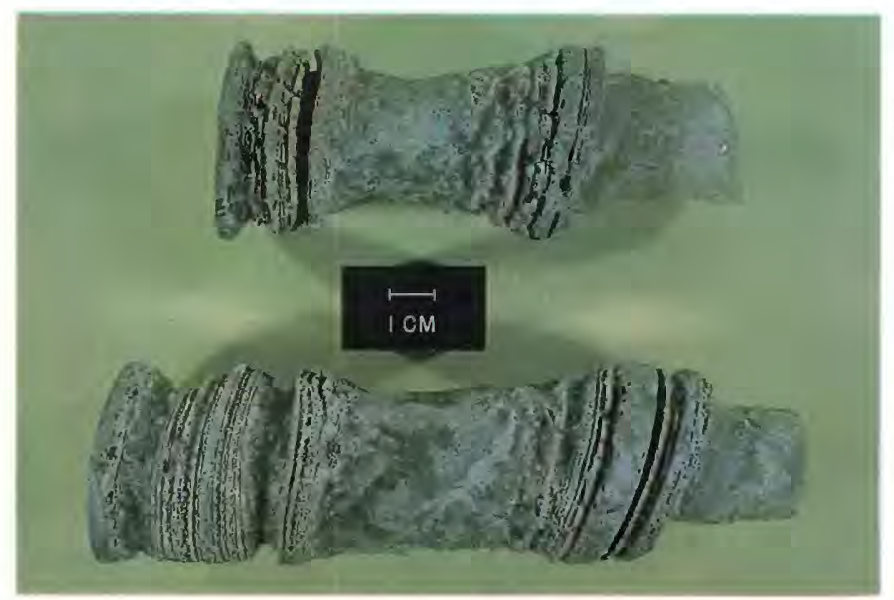

Drill core of alternating thin beds of nahcolite and halite in which drilling fluid has dissolved part of the halite beds (fig. 14).

Sulfate was probably abundant in the lake waters, was reduced by bacteria to sulfide, and precipitated as pyrite in the sediments. Other chemical reactions within the sediments led to the solution of the original clay minerals and the precipitation, in their place, of dawsonite and quartz. These minerals, along with dolomite and feldspars, comprise most of the fine-grained minerals in the oil shale.
During dry periods when Lake Uinta had no outlet, brine-rich in dissolved sodium, bicarbonate, chloride, and sulfate-accumulated in the deepest part of the lake in Piceance basin. The figure shows the lake during a freshening period following a dry period during which a bed of nahcolite and halite had precipitated. A bottom turbidity current swept organic-rich marly sediments down the slope of the basin. An older high-water shoreline terrace is in the background above the mudflats fringing the lake. Such terraces were destroyed by erosion. A large stream may have connected the two large lakes and drained water from Lake Gosiute in southwestern Wyoming into the northern part of Lake Uinta in Colorado and Utah. Numerous streams also flowed into the lake along its southern shores.

The duration of Lake Uinta has been estimated at 13 million or more years, based on radiometric dating of minerals in volcanic ash beds that were deposited with the lake sediments. The unusual longevity of Lake Uinta was made possible by continuous downwarping of the structural basins occupied by the lake. When downwarping ceased, the basins filled rapidly with sediment, and Lake Uinta disappeared about 40 million years ago.

\section{REFERENCES}

Bradley, W. H., 1931, Origin and microfossils of the oil shale of the Green River Formation of Colorado and Utah: U.S. Geological Survey Professional Paper 168, 58 p.

Dyni, J. R., 1981, Geology of the nahcolite deposits and associated oil shales of the Green River Formation in the Piceance Creek basin, Colorado: Boulder, University of Colorado, unpublished Ph. D. thesis, $144 \mathrm{p}$.

1982, Colorado nahcolite deposits: Geology and outlook for development: American Institute of Mining Engineers Transactions, v. 270, p. $1853-1859$.

Lundell, L. L., and Surdam, R. C., 1975, Playa-lake deposition: Green River Formation, Piceance Creek Basin, Colorado: Geology, v. 3, p. 493-497.

Ryder, R. T., Fouch, T. D., and Elison, J. W., 1976, Early Tertiary sedimentation in the western Uinta Basin, Utah: Geological Society of America Bulletin, v. 87 , p. $496-512$.

Piceance basin not only contains huge resources of oil shale and evaporite minerals, but also a variety of other minerals. Their occurrence is described in the following chapter. 


\title{
STOREHOUSE OF ENERGY MINERALS IN THE PICEANCE BASIN
}

\author{
By JOHN R. DONNELL
}

\section{PICEANCE BASIN CONTAINS A WEALTH OF MINERAL RESOURCES, INCLUDING NATURAL GAS, CRUDE OIL, COAL, SHALE OIL, NAHCOLITE, AND DAWSONITE}

The uppermost 10,000 feet of sedimentary rocks in the Piceance basin is a repository for one of the largest energy reserves in the world. Natural gas is produced in considerable quantities from several zones at depths ranging from about 2,000 to 10,000 feet. Additional trillions of cubic feet of gas are trapped in sandstone of low permeability between depths of 6,000 and 10,000 feet in the Mesaverde Group of Cretaceous age. The gas originated in sandstone strata interbedded with coal and organic-rich shale. Commercial production is dependent on development of production techniques that will release the gas from the clay-filled pores of the sandstone.

Small quantities of crude oil that originated from carbonaceous material are obtained from shallow depths in the lower part of the Green River Formation. The favorable geologic conditions for oil production - a thick sequence of sedimentary rocks, source rocks, reservoir rocks, structural traps, and stratigraphic traps-all exist in the Piceance basin. Essentially all formations that comprise the more than 25,000 feet of sedimentary rocks underlying the basin yield crude oil elsewhere in the Rocky Mountain area.

Bituminous coal of low sulfur and ash content originated from the compaction and hardening of plant remains; the coal is mined where the Mesaverde Group is exposed, especially south of the Colorado River. These coal beds also underlie, generally at a depth of less than 8,000 feet, the entire part of the Piceance basin that contains oil shale in the Green River Formation. The estimated in-place coal resource is 60 billion tons, a tremendous energy resource.

By far the greatest concentrated hydrocarbon resource in the world is that of the oil shales contained in the Green River Formation of Colorado, Utah, and Wyoming. The Piceance basin alone contains shales that attain a maximum thickness of 2,000 feet and have an average content of kerogen that will convert to more than one-third of a barrel of shale oil per ton of rock. The total in-place resource is about 1,200 billion barrels of shale oil. Associated with the oil shale are billions of tons of the evaporite minerals, nahcolite and dawsonite, which have a considerable byproduct value for a future oil-shale industry.

\section{OIL SHALE OCCURS IN RICH AND LEAN ZONES}

Throughout an area of about 600 square miles in the northern part of the basin, the oil shale is contained in seven rich oil shale zones separated by six lean oil-shale zones. Rich zones are numbered with $\mathrm{R}$ - prefixes and lean zones are numbered with L- prefixes. Near the northwestern, eastern, and southern margins of the basin the organic content of the beds decreases in all the rich zones except the Mahogany zone and the upper part of the R- 6 zone. The intervening lean oil-shale zones, representing major decreases in the size of Lake Uinta, grade laterally into sandstone or siltstone containing no kerogen. Therefore, at the edge of the basin only the Mahogany zone and the upper part of the R- 6 zone are easily recognized.

In an area of about 100 square miles near the depositional center of the basin, thick beds of nahcolite and halite, deposited during minor decreases in the size of Lake Uinta, are interspersed with the rich oil-shale beds. Also in this area the lean oil-shale beds are enriched in organic matter, thus providing little contrast between the rich and lean zones.

At the northern end of the basin, the 500-foot section immediately overlying the Mahogany zone consists predominantly of sandstone. In the southern part of the basin this sandstone intertongues with and is replaced by oil shale that contains 10 to 15 gallons of shale oil per ton of rock.

Within the Garden Gulch Member of the Green River Formation, a zone of low electrical resistivity on geophysical logs is referred to as the orange zone. Although the orange zone in the center of the basin marks the base of oil shale of current economic interest, an additional 150 to 200 feet of lean oil shale lies immediately below the orange zone. Midway between the southern margin and the depositional center of the basin, the oil-shale sequences occur above the Mahogany zone and below the orange zone, in addition to the seven rich and six lean oil-shale zones. In this area the continuous sequence of oil shale is more than 2,000 feet thick. 
OIL SHALE, WATER RESOURCES, VALUABLE MINERALS, PICEANCE BASIN, COLO.

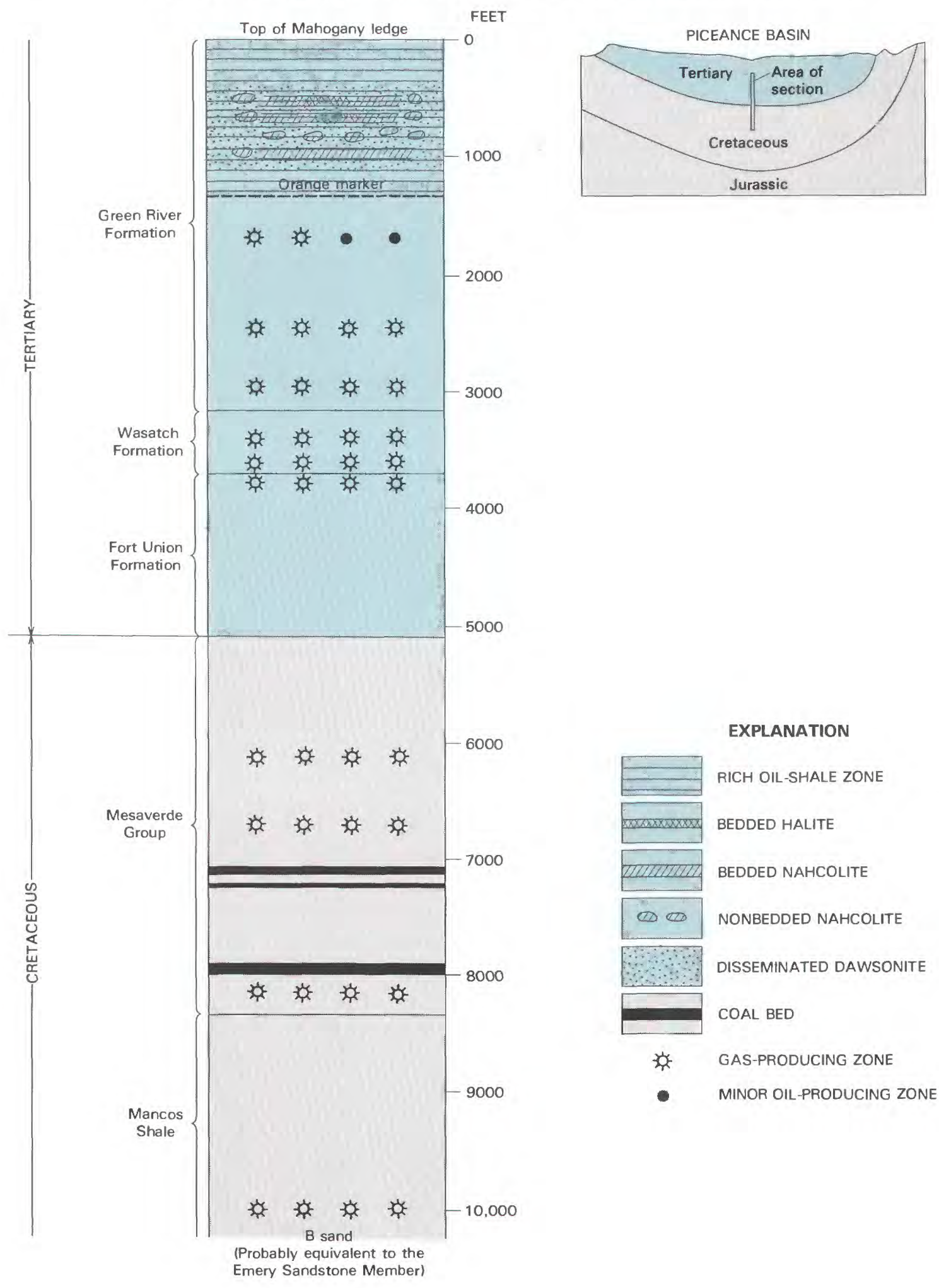

Location of large concentrations of energy minerals in the stratigraphic column (fig. 15). 
THICKNESS,

IN FEET

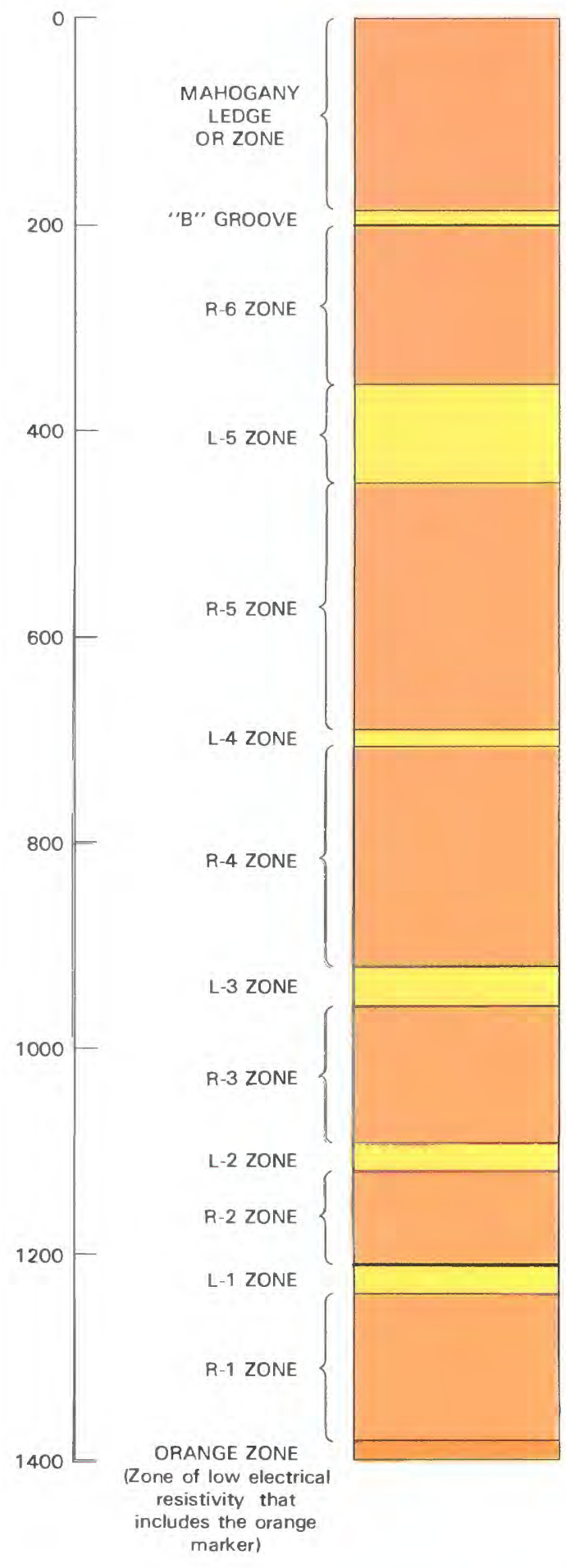

The uppermost and most widespread rich oil-shale zone in the Piceance and Uinta basins. The top of the saline aquifer is in the lower one-third of the Mahogany zone

Represents a major decrease in size of Lake Uinta just prior to the deposition of the Mahogany zone

Nahcolite and halite have been leached from this zone in most of the Piceance basin

Brecciated oil shales in this zone represent intervals where nahcolite and (or) halite beds have been leached. Bedded nahcolite and halite are preserved in small areas

One of the richest oil-shale zones in the Piceance basin. Also contains the greatest resource of nahcolite of any zone. The uppermost significant content of dawsonite is found in this zone

Richest oil-shale zone in the center of the Piceance basin Contains moderate amount of nahcolite and a large amount of dawsonite

Zone containing the greatest amount of dawsonite

Contains three of the most widespread, thick, disseminated nahcolite zones in the basin

Lowest zone containing significant amounts of nahcolite and dawsonite

"Blue Marker", top of the Garden Gulch Member. Base of saline deposition

Rich oil shale in dominantly clay matrix

Clay-shale zone containing no oil shale

Rich and lean oil-shale zones in part of the Green River Formation in the Piceance basin (fig. 16). 


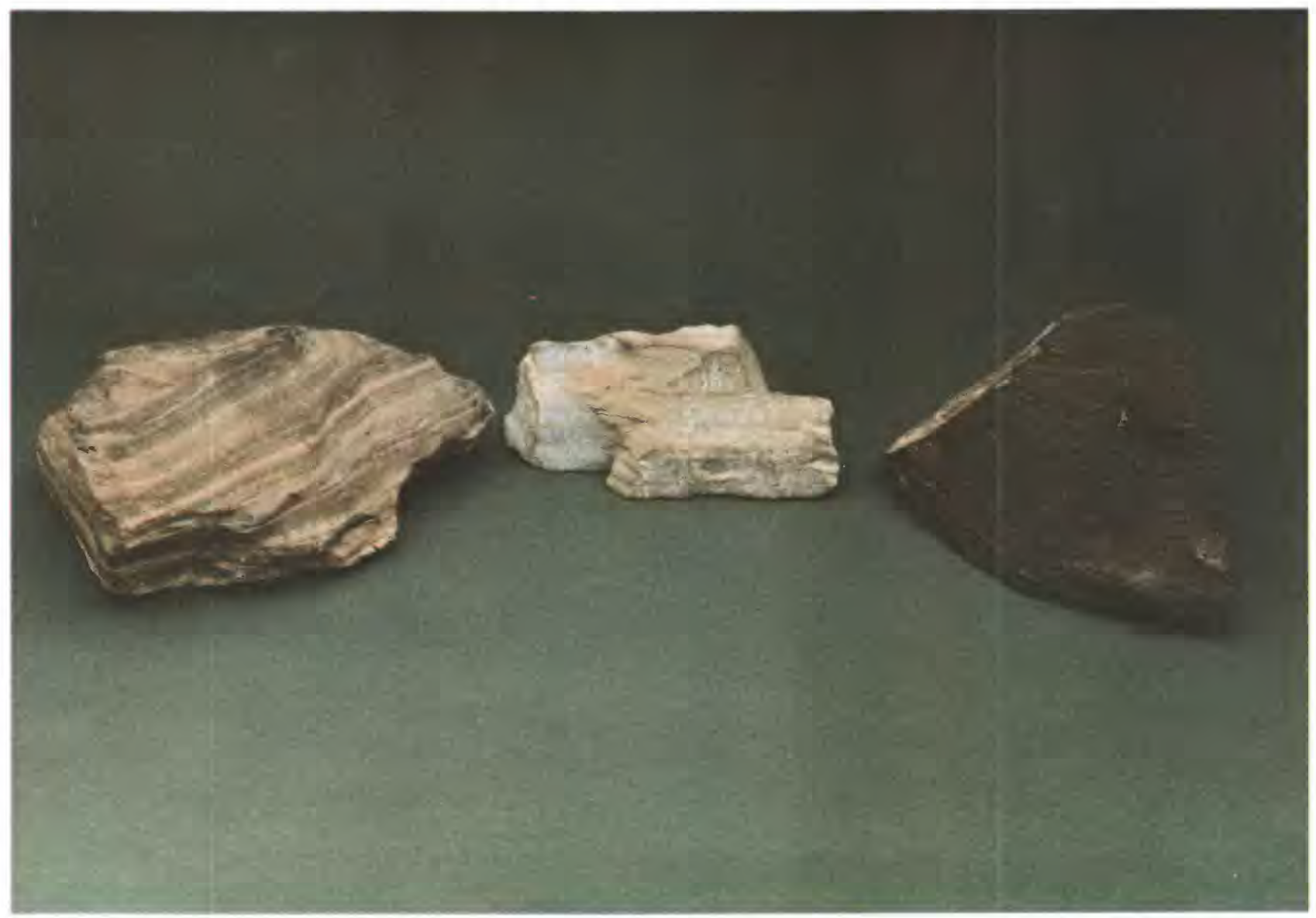

Three samples of oil shale of different grade: Lean sample at center, medium-grade sample on left, high-grade sample on right (fig. 17).

\section{MINING AND EXTRACTION METHODS MAY DEPEND ON THE OIL-SHALE RESOURCE AND OVERBURDEN}

The methods used to develop oil shale probably will depend on the grade and thickness of the oil shale and on the thickness of the overburden. One might assume that oil shales are thickest and richest at the depositional center and that the thickness of overburden above the Mahogany zone is approximately the same near the margins and the center of the basin. However, although the shales are thicker and richer at the center of the basin, the overburden is also generally thicker there because the shale dips toward the center at a steeper angle than the topography.

The relation of overburden to the thickness and richness of oil shale determines the most economic extraction method. Conventional underground mining and surface retorting are planned for the relatively thin but rich oil shale underlying the privately owned land in the southern part of the basin. Mine entry is possible from the well exposed outcrop of the Mahogany zone along the deeply dissected canyons of Roan and Parachute Creeks.

Farther to the north, where the oil shale is thicker and richer, the overburden in much of the area is more than a thousand feet thick. Oil-shale zones several hundred feet thick may be developed using underground mining or a modified in situ retort extraction method.

A U-shaped area of 100 square miles containing a resource of more than 100 billion barrels of oil may be amenable to surface mining. The east limb of the $\mathrm{U}$ is along Piceance Creek in Tps. 1 and 2 S., R. $97 \mathrm{~W}$. The west limb parallels the west margin of the basin in T. 1 N., R. 99 W., and Tps. 1 and 2 S., R. $99 \mathrm{~W}$. The two limbs are connected at T. 2 S., R. $98 \mathrm{~W}$. In most of this area the shale-oil resource is more than 1 million barrels per acre in shale that averages 25 or more gallons per ton. The waste-to-ore ratio is less than 1:1 in much of the area.

The development of oil shale is discussed in greater detail in the chapter "Development of the oil shale and associated minerals." 


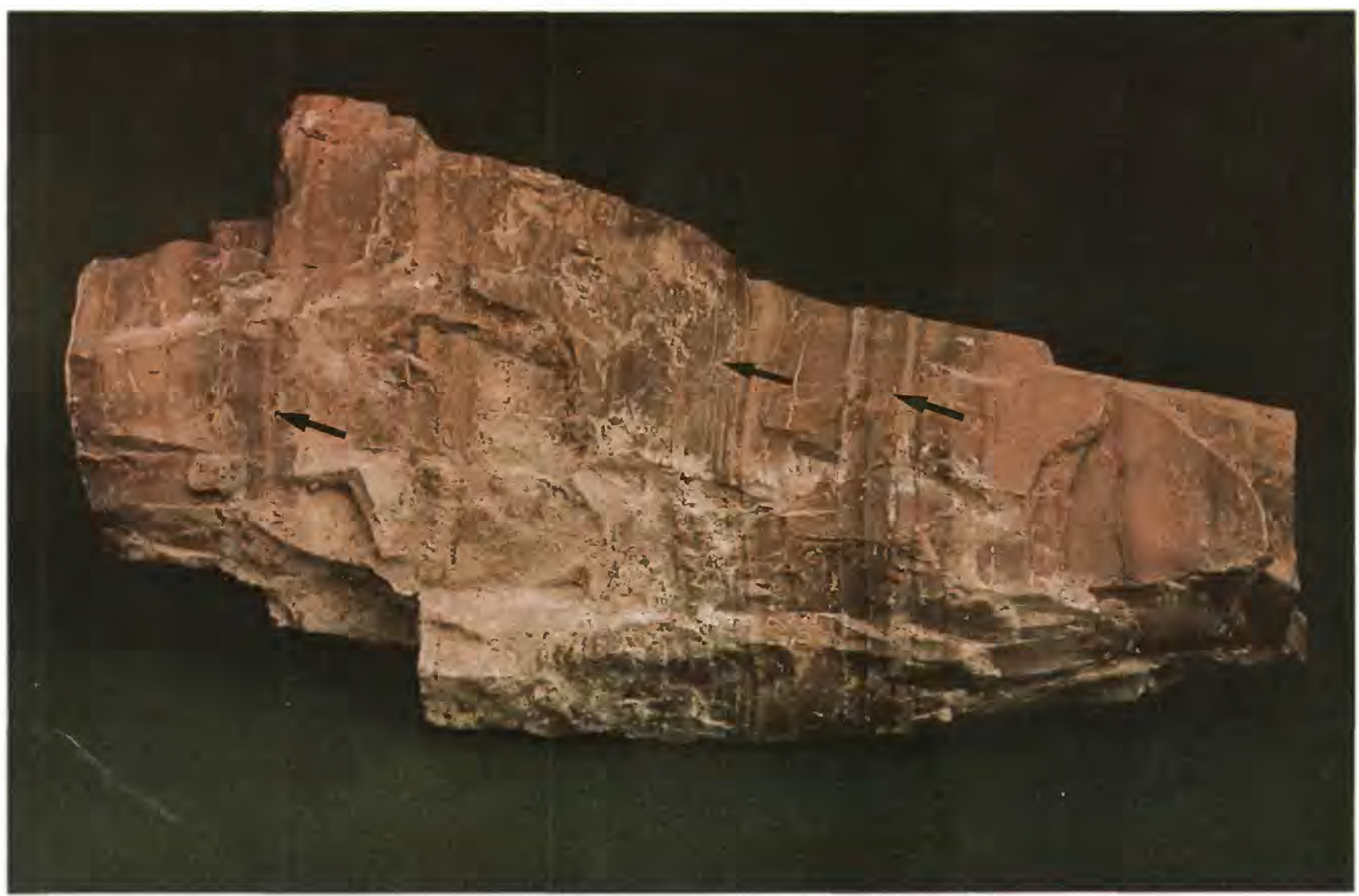

Sample of nahcolite from Piceance basin. Finely laminated bands (arrows) are included oil shale (fig. 18).

\section{THE OWNERSHIP OF OIL-SHALE MINERAL RIGHTS HAS CHANGED OVER THE YEARS}

Oil shale, coal, tar sands, crude oil and gas, and various sodium minerals on Federal lands are leasable under provisions of the Mineral Leasing Act. Before 1920, oil shale was a locatable mineral and claims could be staked. From 1900 to 1920, hundreds of thousands of acres of oil-shale land was staked by prospectors swarming the hills of northwest Colorado, northeast Utah, and southwest Wyoming. Many of these claims were patented between 1900 and 1960, and were sold to industry by the original claimants or their heirs.

Since the early 1960's, the Federal government has not patented any oil-shale claims because title to many mining claims is under litigation. Prior to 1916, homesteaders along the valleys of Piceance Creek and its major tributaries acquired both mineral and surface interests. Private lands purchased by industry during recent years form a band about one-fourth to one-half mile wide and 1 to 20 miles long, winding along the stream valleys in an area predominantly of public domain.

\section{REFERENCES}

Austin, A. C., 1971 (1972), Structure contours and overburden on the top of the Mahogany zone, Green River Formation, in the northern part of the Piceance Creek basin, Rio Blanco County, Colorado: U.S. Geological Survey Miscellaneous Field Studies Map MF-309.

Bradley, W. H., 1931, Origin and microfossils of the oil-shale of the Green River Formation of Colorado and Utah: U.S. Geological Survey Professional Paper 168, $58 \mathrm{p}$.

Cashion, W. B., and Donnell, J. R., 1972, Chart showing correlation of selected key units in the organic-rich sequence of Green River Formation, Piceance Creek basin, Colorado, and Uinta basin, Utah: U.S. Geological Survey Oil and Gas Investigations Chart OC-65.

Donnell, J. R., 1961, Tertiary geology and oil-shale resources of the Piceance Creek basin between the Colorado and White Rivers, northwestern Colorado: U.S. Geological Survey Bulletin 1082-L, p. $835-891$.

Hornbaker, A. L., Holt, R. D., and Murray, D. K., 1976, 1975 Summary of coal resources in Colorado: Colorado Geological Survey Special Publication No. 9, 17 p.

Hite, R. J., and Dyni, J. R., 1967, Potential resources of dawsonite and nahcolite in the Piceance Creek basin, northwest Colorado, in Fourth Oil Shale Symposium: Colorado School of Mines Quarterly, v. 62, no. 3, p. 25-38. 


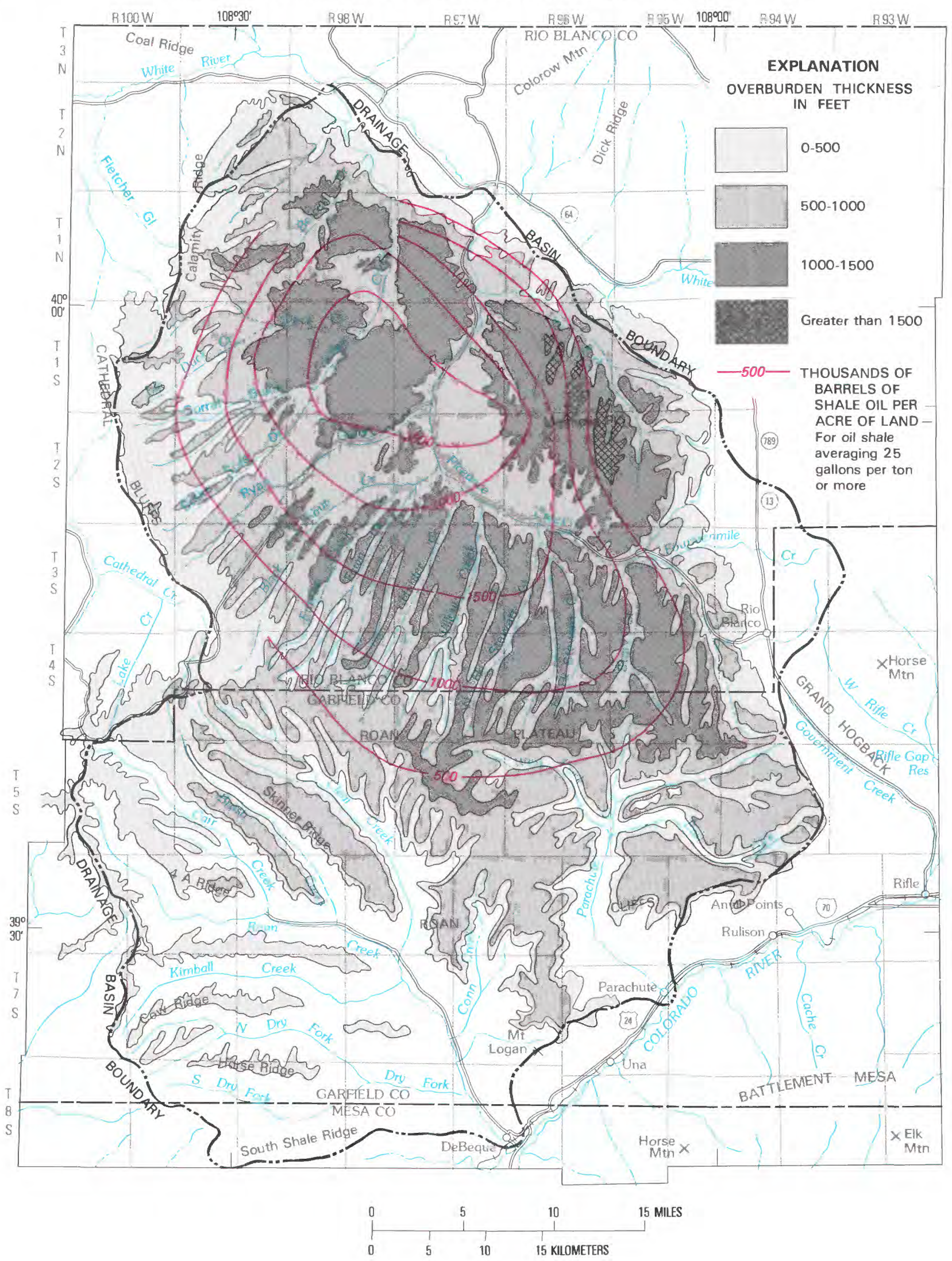

Total shale-oil resources and overburden thickness above Mahogany zone (fig. 19) 


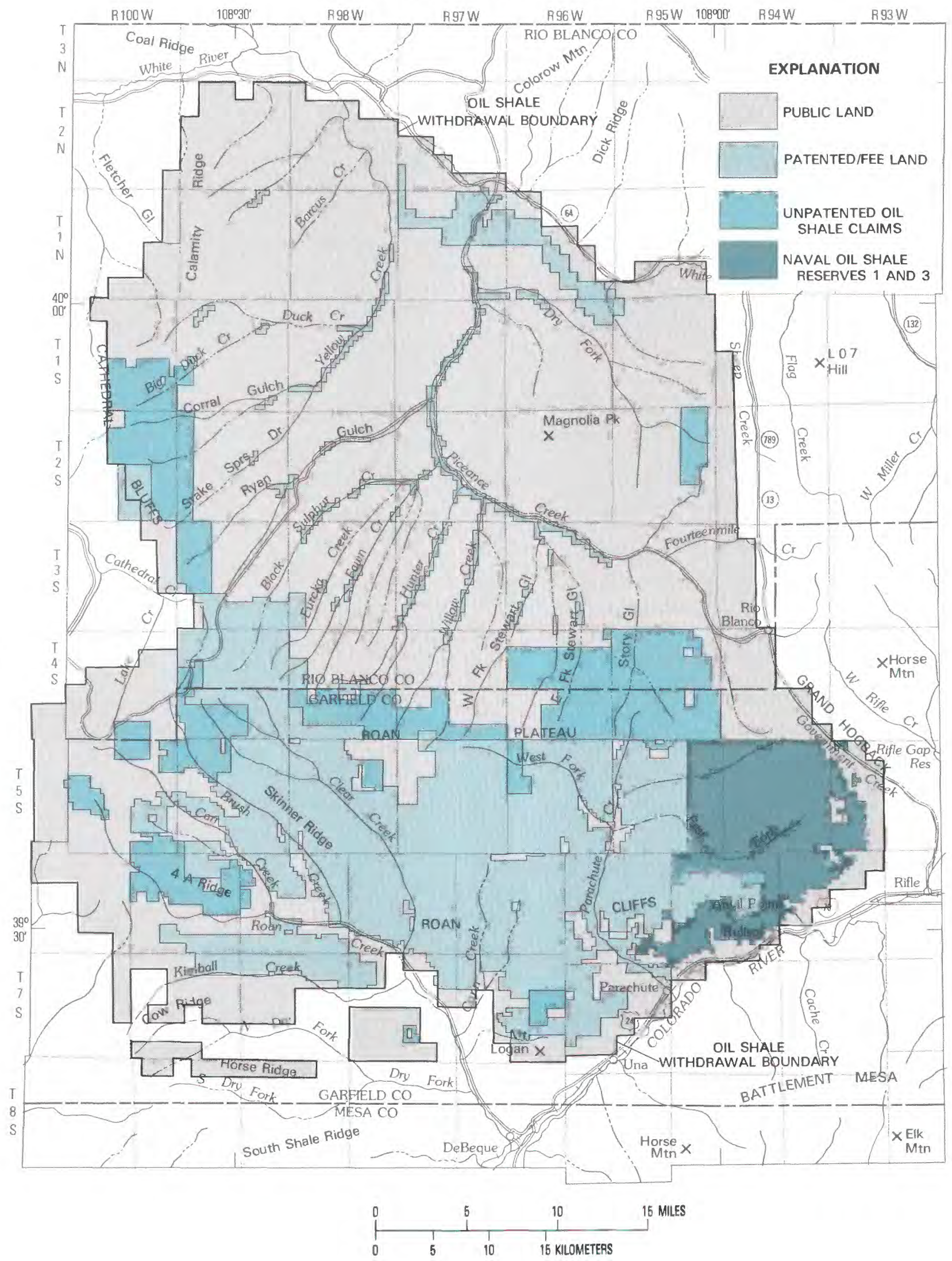

Mineral ownership in the Piceance basin (fig. 20). 
Mullens, M. C., 1976, Structure contours and overburden on the top of the Mahogany zone, Green River Formation in the southern part of the Piceance Creek basin, Rio Blanco and Garfield Counties, Colorado: U.S. Geological Survey Miscellaneous Field Studies Map MF-746.

Rocky Mountain Association of Geologists, 1974, Guidebook to the energy resources of the Piceance Creek basin, Colorado, 25th Annual Field Con-

ference: Denver, Colo., $302 \mathrm{p}$.
Oil-shale and associated mineral development require an understanding of geology, hydrology, mining, mineral extraction, mineral transportation, and land reclamation. A brief description of these subjects follows. 


\title{
DEVELOPMENT OF THE OIL SHALE AND ASSOCIATED MINERALS
}

\author{
BY G. A. MILLER
}

\section{OIL-SHALE DEVELOPMENT IN PICEANCE BASIN BEGAN ABOUT 1900}

Before 1900, local Ute Indians recognized the unusual nature of oil shale, and they termed it "the rock that burns." Eventually the occurrence of oil shale in the Piceance basin was noted by settlers from the East. Oil shale reportedly was burned as a frost deterrent in fruit orchards at Palisade, Colo. (about 11 miles northeast of Grand Junction), as early as 1905. Mining claims were filed on oil-shale outcrops beginning about 1910 . The U.S. Bureau of Mines and the U.S. Geological Survey began scientific studies of the deposits during the period 1912-14, and National recognition of the size and potential of the deposit in the southern part of the basin led to the establishment of the Naval Oil Shale Reserves in Colorado and Utah in 1916.

From 1915 to 1920, thousands of acres in the outcrop areas, mostly along Parachute and Roan Creeks, were claimed under the 1872 mining law. Claiming stopped with passage of the 1920 Minerals Leasing Act, which provided for leasing of oil shale. At that time, the rich, thick oil-shale, nahcolite, and dawsonite deposits in the middle part of the basin were unknown.

Many small experimental retort operations were tried near De Beque, Colo., from 1918 to 1922, but probably fewer than a thousand barrels of shale oil were produced. Promotional schemes apparently were common in the area, some purporting to recover gold, silver, and other valuable materials along with the shale oil.

Work by the U.S. Bureau of Mines on oil shale included laboratory studies from 1919 to 1924 and mining and retorting at the Rulison site near Rifle, Colo., from 1925 to 1929. Approximately 1,500 barrels of shale oil were produced. This early development ended when large petroleum fields were discovered in Texas and California, and Federally owned oil-shale lands were withdrawn from leasing in 1930.

Public Law 78-290, the Synthetic Fuels Act (1944), authorized the U.S. Bureau of Mines to conduct research and development for synthetic fuels, including oil shale. The Bureau began construction that same year at the Anvil Points site, a few miles east of the old Rulison site. This research, which focused on mining and retorting methods, continued until 1956.

During the 1950's, 1960's, and 1970's several research programs experimented on a small scale with shale-oil and mineral-extraction methods, including in situ retorts and aboveground retorts. A proposal during the late 1960 's to use heat from an underground atomic explosion to recover shale oil was not tried by onsite experiments, however. In 1968, a leasing attempt by the U.S. Department of the Interior resulted in rejection of all bids for three tracts in the Piceance basin. Onsite research for in situ recovery methods began on private land in the Logan Wash area of southern Piceance basin in 1972.

In 1974, after the preparation of an environmental impact statement, the Department of the Interior leased oilshale tracts $C-a$ and $C-b$. The bid prices were surprisingly high, primarily because of expensive world oil prices (the $\mathrm{C}$-a bid price was about $\$ 210$ million and the $\mathrm{C}-\mathrm{b}$ bid price was about $\$ 118$ million). The prototype program had four goals:

1. To provide a new source of energy to the Nation,

2. To insure the environmental integrity of the affected areas,

3. To permit an equitable return to all parties, and

4. To develop management expertise.

Development on Federal tracts C-a and C-b began in 1978, after collection of predevelopment data and preparation of a development plan, and continues to date.

Also in 1974, a consortium of several companies began testing aboveground retorting techniques at the Anvil Points facility of the U.S. Bureau of Mines. In 1980-81, development of two oil-shale facilities began on private land in Parachute Creek valley, and preliminary plans were announced for similar developments in Roan Creek valley.

\section{VARIOUS MINING METHODS ARE PROPOSED}

The operators at most sites in the Piceance basin propose to mine oil shale at a larger scale than ever before attempted. The project life of mines may be decades or centuries, the saleable products are worth trillions of dollars, and the volume of waste generated may be as much as millions of cubic yards per day.

In the northern part of the basin the associated minerals nahcolite and dawsonite may be mined in conjunction with the oil shale if a developer can acquire a multimineral lease. This type of lease has not been offered previously. 


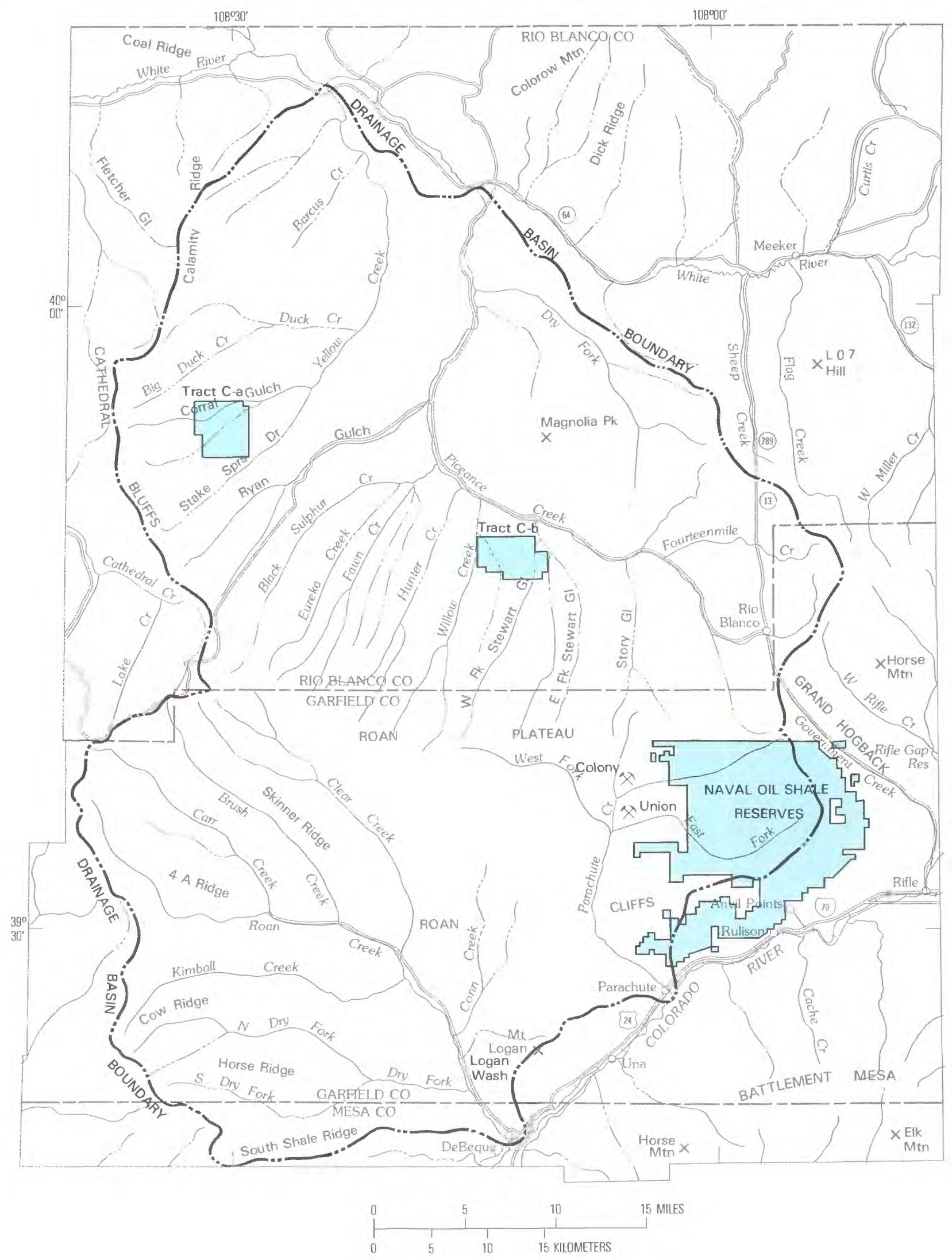

Modern and historic sites related to oil-shale development (fig. 21). 


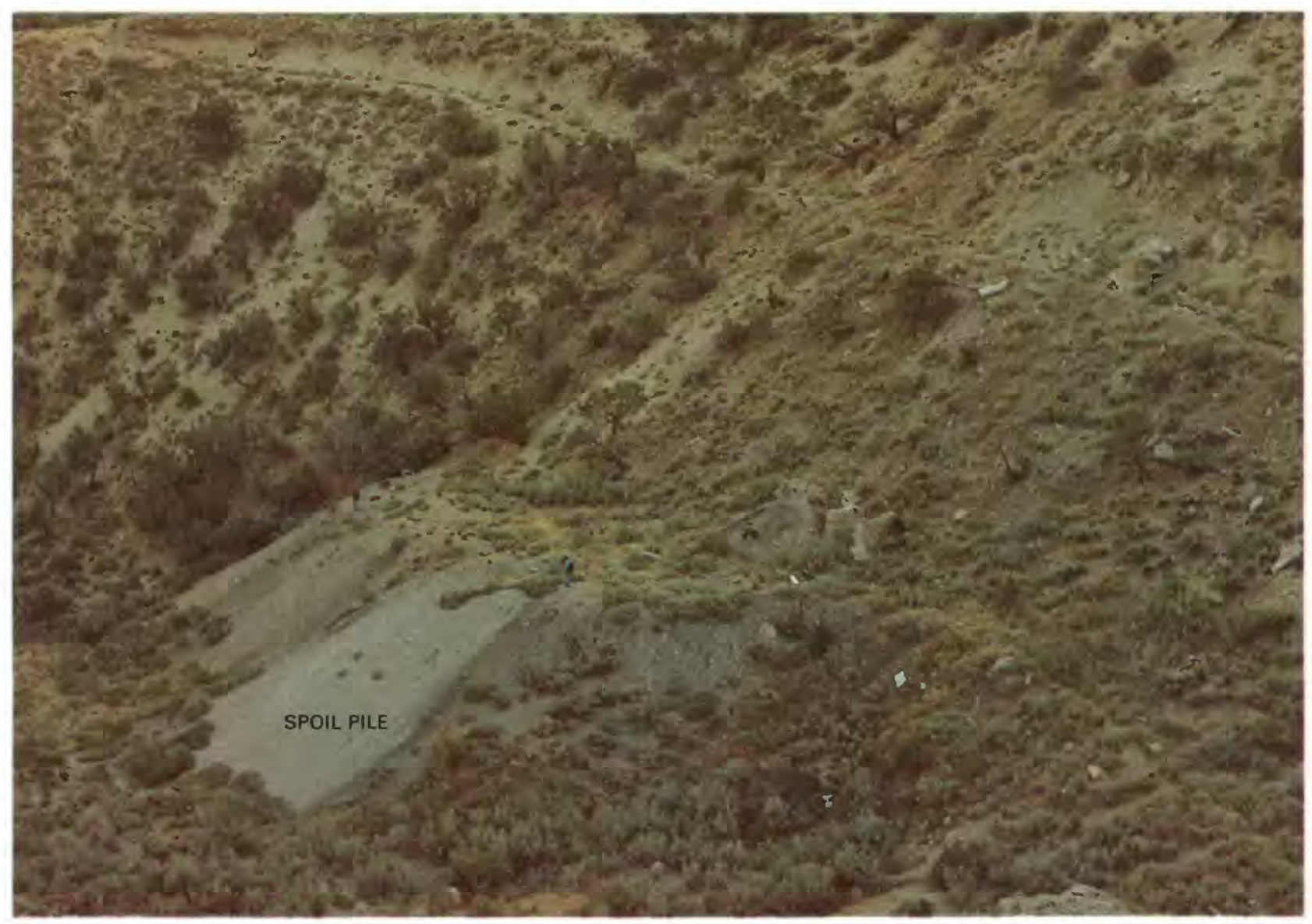

Spoil pile of retorted shale from the experimental retort of the U.S. Bureau of Mines, 1925-29 (fig. 22).

Mining of the oil shale in a single operation is desirable because:

1. Resource recovery probably will be greater with a single mining operation;

2. Secondary recovery or a second mining operation in such a large, thick deposit is inefficient and expensive; and

3. Mine drainage, required at most sites, probably would have to be repeated during a second mining operation.

Mining methods generally are classified as either surface mining or underground mining. In surface mining the entire mine is "open to the sky." Proposed surface mines in the Piceance basin typically are migrating open pits, in which mined and processed material is used to backfill the abandoned pits. Because oil-shale deposits typically are covered by barren rock, the thickness of the overburden rock in comparison to the thickness and grade of the underlying oil shale is an important consideration in planning such mines. The thickness of the overburden and oil shale vary considerably because of topography and geologic structure. (See map, fig. 19.)
Conditions are considered favorable for surface mining in a large area in the west-central part of the basin where the ore is thick and the overburden is thin. Several preliminary feasibility studies on surface mining have recommended the area near tract C-a as a logical place to begin a surface mine. The top of the rich oil shale lies at or within 500 feet of the land surface, and the mineable thickness of oil shale locally exceeds 1,000 feet.

The general sequence for surface mining would be:

1. Mine drainage, if required.

2. Removal of overburden and stockpiling soil or alluvial material for later use in reclamation.

3. Widening and deepening the open pit to the bottom of the ore, and starting shale-oil production.

4. Extension of the pit (migration) into unmined areas.

5. Backfilling the pit with overburden and waste (when a sufficient area is open).

During overburden removal, the waste material is placed away from the mining area. Oil-shale retorting can begin during pit excavation. The waste material, including retorted shale, continues to be placed away from the mining area 


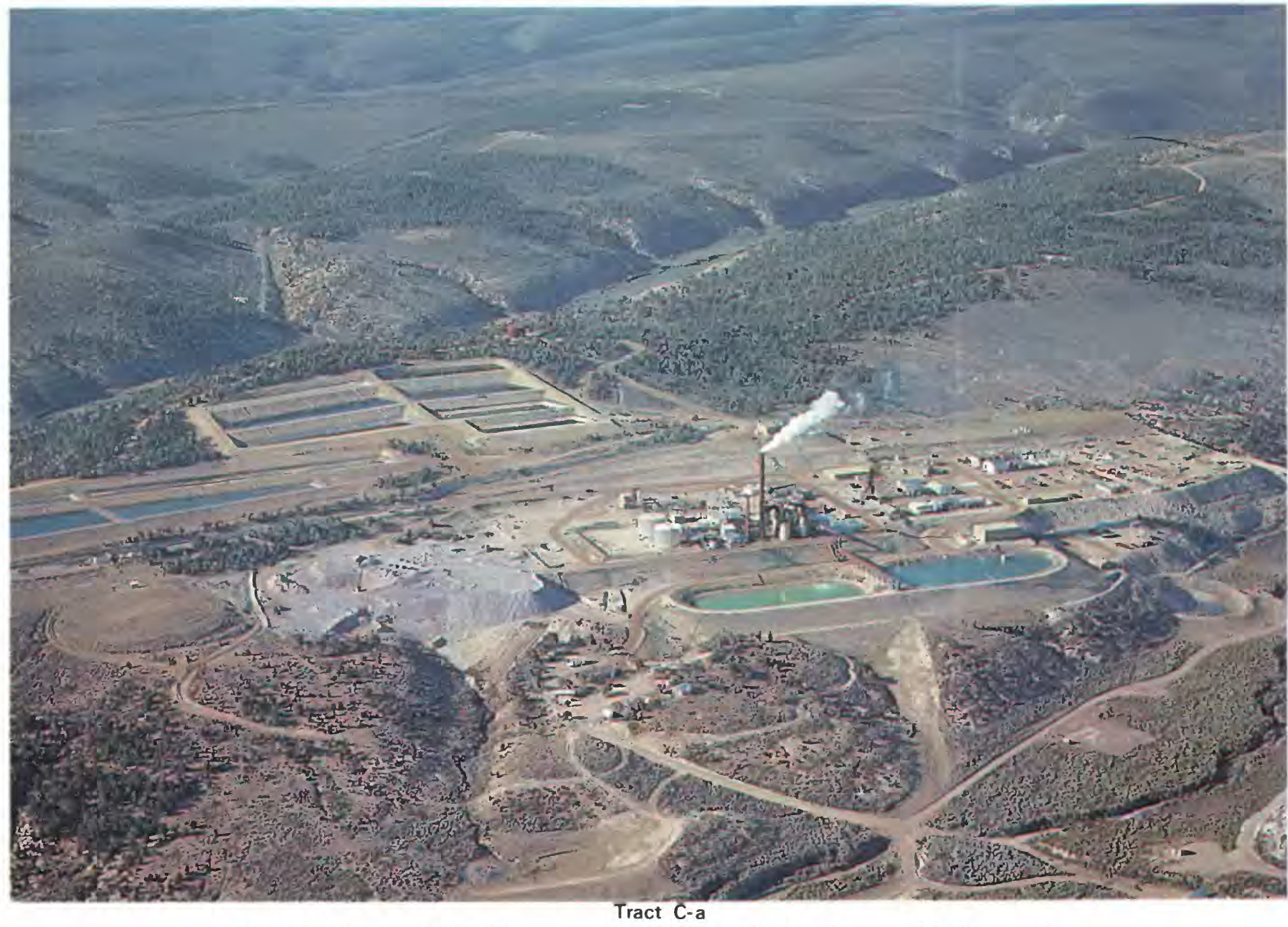

Oil-shale plants at Federal lease tracts C-a and C-b (fig. 23 above and facing page).

during pit excavation, but is backfilled in the mined-out pit during pit migration. During the entire operation, topsoil, poorly developed soil, or alluvium suitable for land reclamation can be separated and stored for future use. Where conditions are favorable, surface-mining techniques allow recovery of most of the oil shale, except under the sloping pit walls.

The underground mining method commonly considered for oil shale is the room-and-pillar mine, in which tunnels are dug into the oil shale, either from surface outcrops on canyon walls or from shafts, and large rooms are excavated using a single- or multiple-level advance as the ore is mined. The rooms are separated by pillars of unmined oil shale that support the mine roof. Subsidence of the land surface may occur during and after underground mining. Subsidence results mostly from the mining and drainage that reduce support of the overlying material. Subsidence can be minimized by injecting water into abandoned mines and by backfilling mined-out zones with waste rock and processed shale.
However, such injection and backfilling increases development costs. Tradeoffs of allowable subsidence against resource recovery are probable because the likelihood and magnitude of subsidence increases as resource recovery increases. In those regions where subsidence would be undesirable or damaging, mining may need to be restricted.

In sections of oil shale that are only 60-80 feet thick, room-and-pillar mining methods can recover as much as 60 to 70 percent of the resource, and more if the pillars are partly mined during the final stages. In the thicker layers of oil shale that occur beneath most of the Piceance basin, roomand-pillar mines can recover only $10-30$ percent of the resource.

Other underground mining and extraction methods, such as block caving and longwall mining methods, would recover a higher percentage of the resource, but are presently too costly. New underground methods may be designed to more economically recover a high percentage of the resource. 


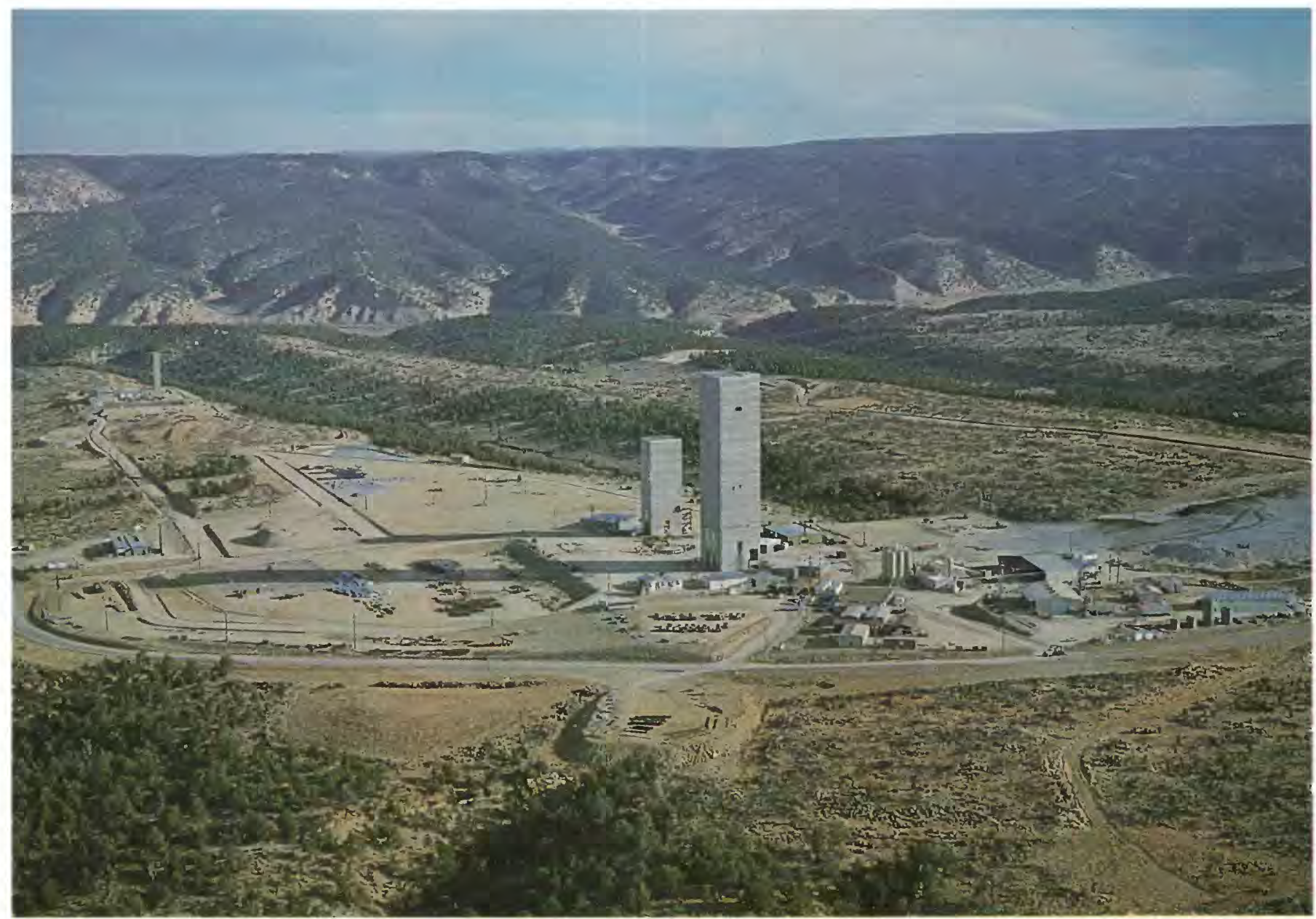

Tract C-b

\section{OIL SHALE CAN BE PROCESSED IN ABOVEGROUND AND IN SITU RETORTS}

Proposals for oil-shale processing include a variety of retorts operated aboveground, and several types of underground in situ retorts and modified in situ retorts. All methods of retorting heat the shale to a minimum temperature of about $900^{\circ} \mathrm{F}$, at which most retorting occurs.

The different types of aboveground retorts have several features and functions in common:

1. All require that the oil shale to be retorted is crushed to a size ranging from less than $1 / 4$ inch to as much as 6 to 10 inches.

2. All have mechanisms to move the ore continuously through the retort.

3. All incorporate features to control the temperature and rate of movement through the retort.

4. All provide for separation of shale oil, water, and gas products.

5. All are sensitive to the richness of the feedstock; they cannot process shale efficiently below a minimum grade.
The heat in aboveground retorts is supplied either direct$l y$, by burning some of the oil shale in the retort, or indirectly, by mixing preheated gases or solids with the oil shale to achieve retorting. The direct methods burn the carbon in retorted shale after the hydrocarbons have been driven off by heat. The indirect, or externally heated, methods use a supply of gas or liquid fuels either brought to the site or diverted from the retort products. Some indirect methods obtain process heat by burning residual carbon in retortedshale fragments in a separate furnace.

In situ and modified in situ processing techniques are batch methods designed to minimize the mining, transporting, crushing, and other operations associated with aboveground retorting. Several methods that heat the shale in place have been proposed and attempted. In situ burning of shale and residual carbon, injection of hot steam or hot gases, and heating by electricity or microwaves have been tested in laboratory studies and onsite. Steam is generated at land surface and injected into wells open to the oil shale, or injected into a modified in situ retort. Hot gases may be either produced at a surface facility or produced by the burning of residual carbon and some oil shale in a directly 

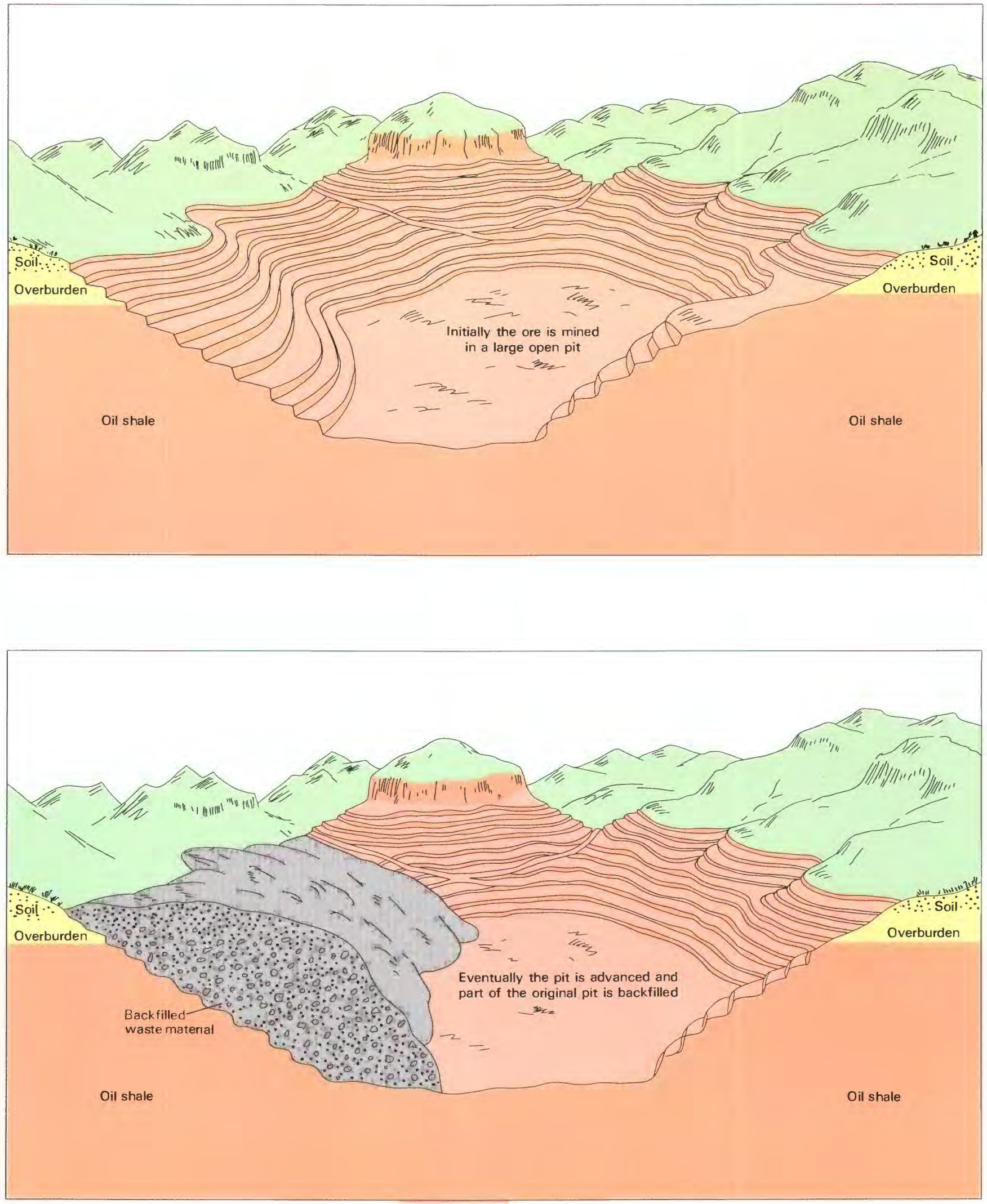

Surface mining using a migrating open pit (fig. 24). 


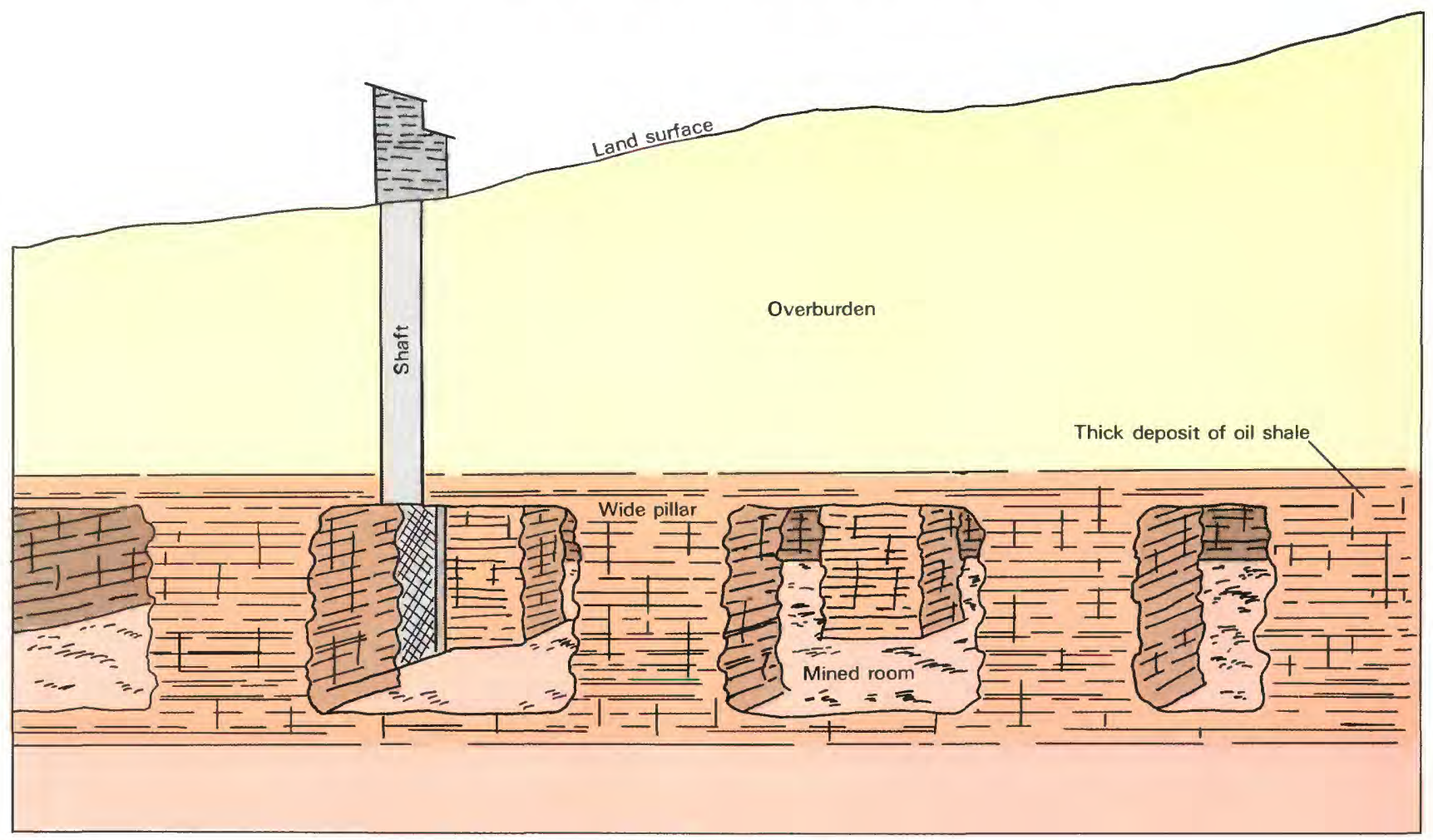

ACCESS TO MINE THROUGH VERTICAL SHAFT

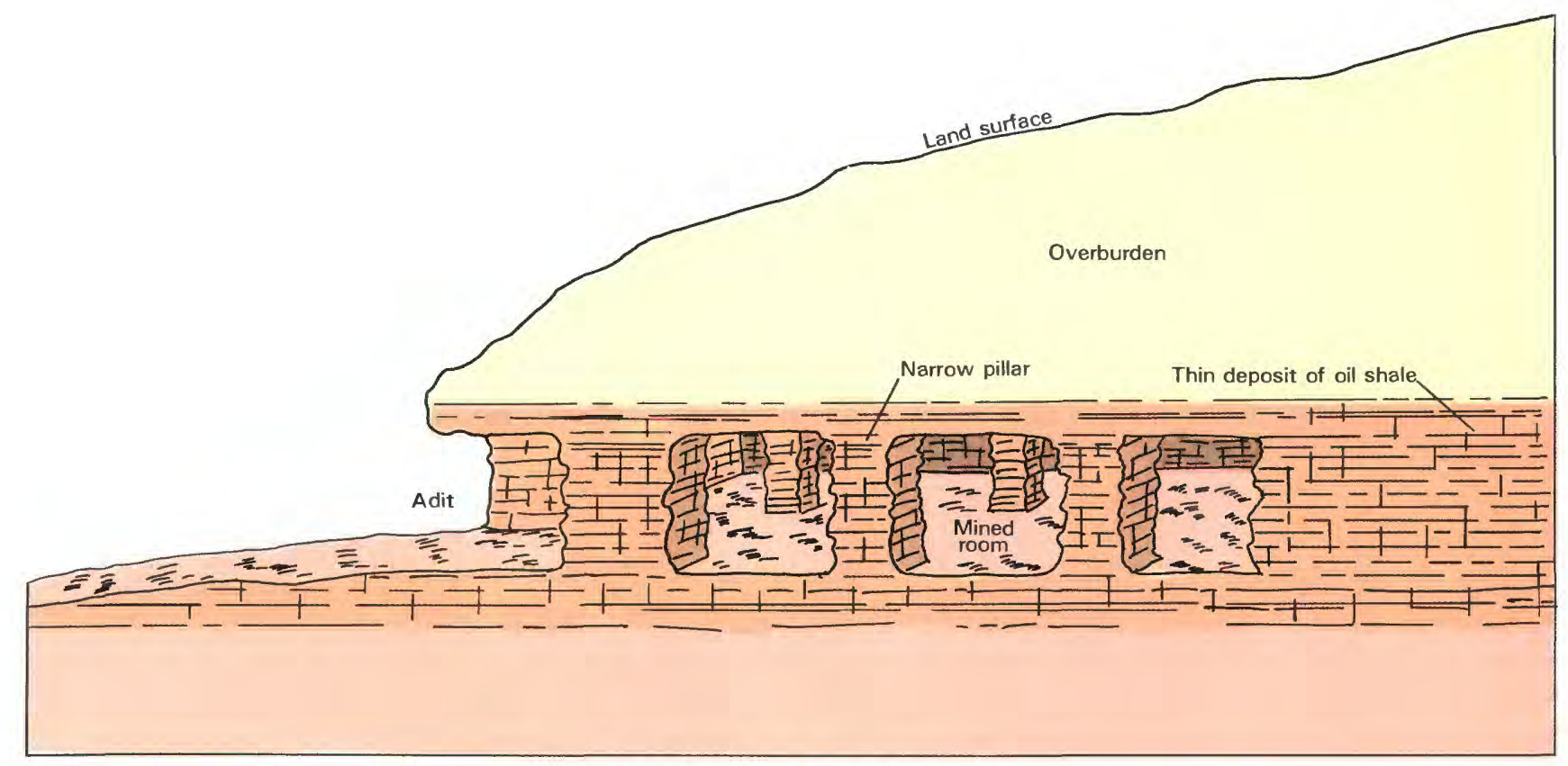

ACCESS TO MINE THROUGH ADIT

Underground mining using room-and-pillar method (fig. 25). 


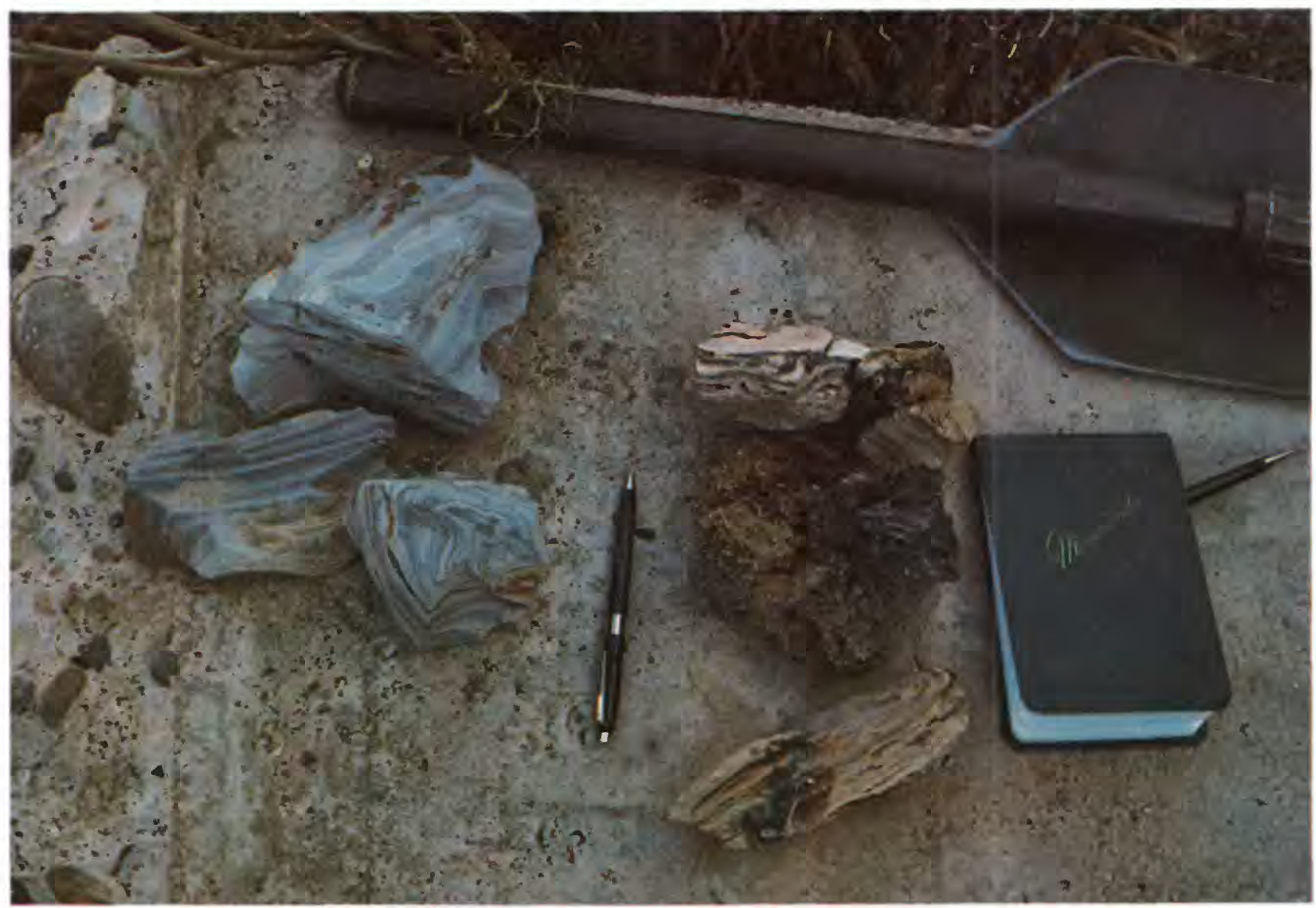

Samples of crushed but unretorted oil shale (left) and retorted oil shale (right) from field tests, Rulison site, 1928 (fig. 26).

heated, modified in situ retort. Proposed electrical-heating methods include resistance and induction (microwave) heating.

Significant differences distinguish the commercial products and by-products of one retorting method from another. The differences are related to the temperature during retorting, and whether direct or indirect methods are used. Direct retorting methods tend to operate at much higher temperatures than the minimum required for retorting. The burning is accomplished by injecting air into the retort, and the resulting high temperatures tend to cause calcining (conversion to calcium and magnesium oxides) of the carbonate minerals, calcite and dolomite, in the oil shale.

The fuel products resulting from retorting are shale oil and a hydrocarbon (synthetic natural) gas. The hydrocarbon gas is greatly diluted with nitrogen from the inlet air and with dioxide from combustion of carbon and from the calcining of the carbonate minerals. The retorted shale typically contains a large percentage of calcium and magnesium oxides. Heating at temperatures greater than $2,000^{\circ} \mathrm{F}$ for a long period causes some of these solid-state oxides to react with other minerals to produce silicate minerals that resemble those in igneous rocks.
Indirect retorting methods typically operate at the minimum temperature necessary to achieve efficient retorting. The methods also produce shale oil and hydrocarbon gas that is not diluted by nitrogen and carbon dioxide because air is not injected and the retorting temperature is below the temperature required for calcining.

\section{WATER DEMANDS FOR OIL-SHALE DEVELOPMENT MAY BE GREAT}

An oil-shale mine and processing plant will require water supplies for various uses. The supplies will be derived from some combination of ground water drained from mines, deep ground-water reservoirs, surface-water diversions, surface reservoirs, and imported water. The water will be consumed during operations for:

1. Dust control;

2. Drilling;

3. Steam generation for various industrial processes, including retorting and product upgrading;

4. Exhaustion of moisture-laden mine-ventilation air to the atmosphere; 
5. Power generation;

6. Cooling;

7. Moistening and cooling retorted shale;

8. Reclaiming and revegetating retorted shale and disturbed lands; and

9. Removal of impurities from evolved gases.

The amount of water required is not well defined, but most estimates range from 1 to 4 barrels of water per barrel of shale oil produced. The wide range is related partly to the different requirements for different oil-shale mining and retorting processes and partly to the uncertainties in projecting water uses based on small-scale industrial experience. Industrial water requirements for various levels of shale-oil production and volumetric ratios of water to oil can be determined. The average rate at which the United States imported crude oil in 1980, 5.16 million barrels per day, is shown in the graph for comparison.

Estimates of the increase in municipal water use are based on projections of population growth that will accompany large-scale development of oil shale. A 50,000-barrel-perday mine and plant may employ about 3,000 people. The total population may be three to five times larger than the work force. Therefore, a 50,000-barrel-per-day plant may support a population of 9,000 to 15,000 people. Assuming the water requirement is 100 gallons per person per day, the graph relates municipal water requirements to different levels of shale-oil production and population per plant. The municipal water requirements are less than the industrial water requirements for shale-oil production, as indicated by the different vertical scales on the graph of water requirements.

Additional discussions of water supplies for oil-shale development are found in the chapters "Hydrologic system of the Piceance basin" and "Benefits, requirements, and effects of different levels of oil-shale development."

\section{MINERAL TRANSPORTATION WILL DEPEND ON THE VOLUMES AND TYPES OF PRODUCTS}

A commercial oil-shale industry in Piceance basin will produce large volumes of shale oil and potentially large volumes of by-products such as sodium and aluminum minerals, ammonia, sulfur, hydrocarbon gas, liquified petroleum gas, and coke. Other potential products are nitrogen and carbon dioxide, which are the main waste gases from some high-temperature retorts. A significant activity therefore will be the transportation of mineral products to markets or to existing conveyances, which are typically hundreds of miles from the mines and plants. During the early stages of a developing industry, the volumes of products are small and probably will be shipped by truck and railroads.
However, the volume of most products will need to be reduced because transportation is so expensive. Most shale oil probably will be processed to be equivalent in composition to the crude oil supplied to oil refineries. Pipelines are probably the most practical method of moving shale oil, hydrocarbon gas, liquified petroleum gas, and ammonia. Proposed pipeline routes for moving shale oil from the basin, initially connecting with existing pipe lines, are based on rates of production from individual sites ranging from 10,000 to 100,000 barrels per day. Proposed common-carrier routes extend southwest to Lisbon Valley, Utah, northwest to Rangely, Colo., and northeast to the area between Casper and Guernsey, Wyo. Because the existing common-carrier pipelines at these sites have a limited capacity, transportation of additional large volumes will not be possible. Separate pipelines, perhaps along some of the same corridors, would be necessary for transport of large amounts of ammonia, hydrocarbon gas, and liquified petroleum gas.

Sulfur, coke, and sodium and aluminum minerals probably will be shipped by railroad. A major railroad line connecting Denver and Salt Lake City runs along the south edge of the basin. Preliminary studies indicate that it may be feasible to extend a line northward from Rifle, Colo., down the valley of Piceance Creek, and to the central part of the basin.

\section{RECLAMATION WILL BE REQUIRED FOR ABANDONED MINES, SPOIL PILES OF RETORTED SHALE, AND IN SITU RETORTS}

A major concern of governments, private interests, and the general public is the effect of large scale oil-shale development on the land and water resources in the area. Such development, involving perhaps a dozen or more mines, could eventually affect the land surface, underlying rocks, and water of the entire basin.

\section{ABANDONED MINES}

Abandoned mines need to be left in a stable condition in order to reduce the subsidence of the land surface and to avoid the disruption of surface-water and ground-water flow systems. Long-term continuous subsidence is likely above large mines, especially where the overburden is thin or weak.

Large-scale subsidence also would restrict uses of the land surface and possibly would cause damage to streams, canals, reservoirs, and pipelines. In many underground mines throughout the world, subsidence has been successfully controlled by backfilling the old mine workings with waste material, which provides partial support for the pillars and the mine roof. At an abandoned oil-shale mine, perhaps 60-80 percent of the mined-out materials (waste rock and retorted shale) could be backfilled in the mine. The benefits of backfilling are: 


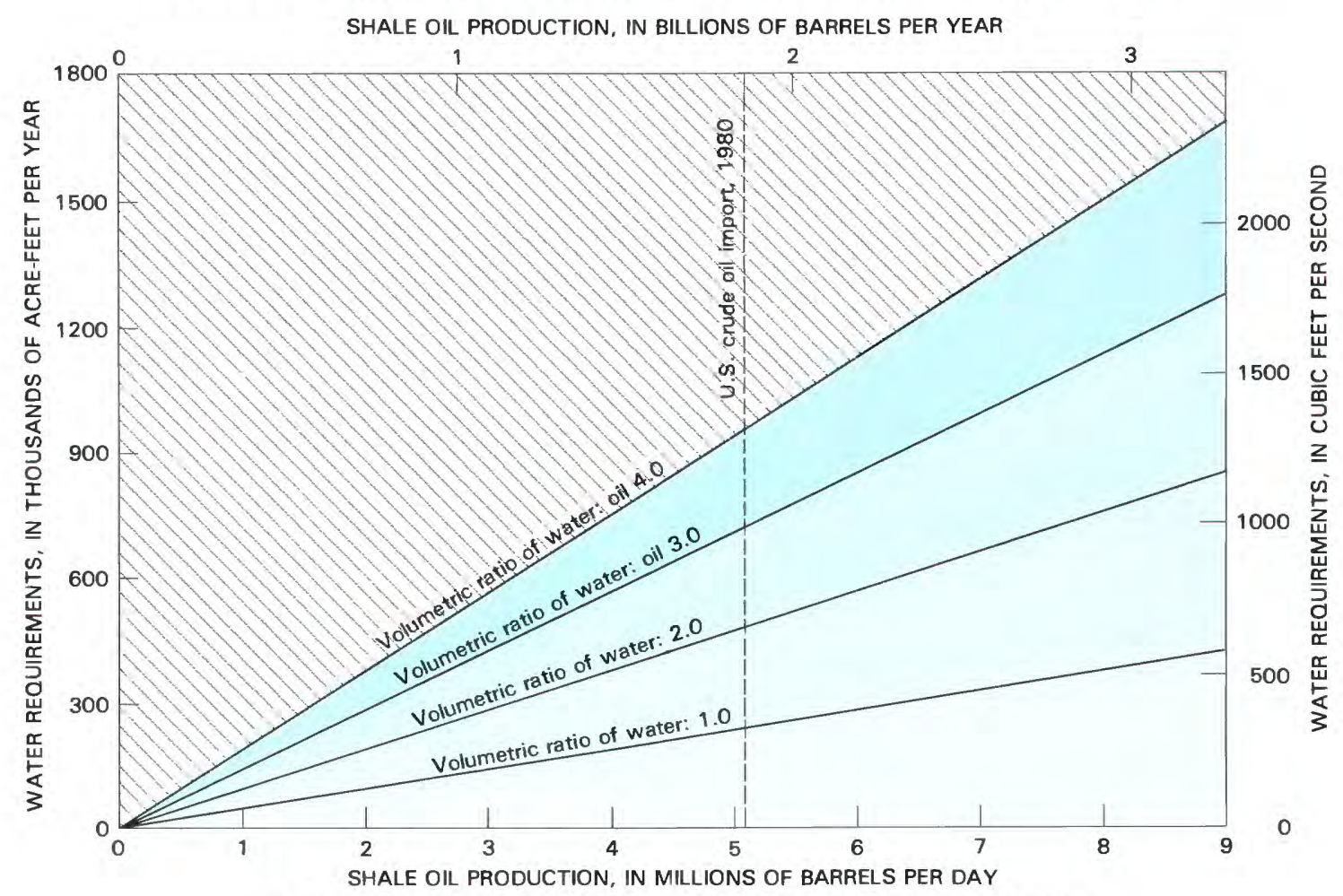

A. INDUSTRIAL WATER REQUIREMENTS FOR SHALE-OIL PRODUCTION

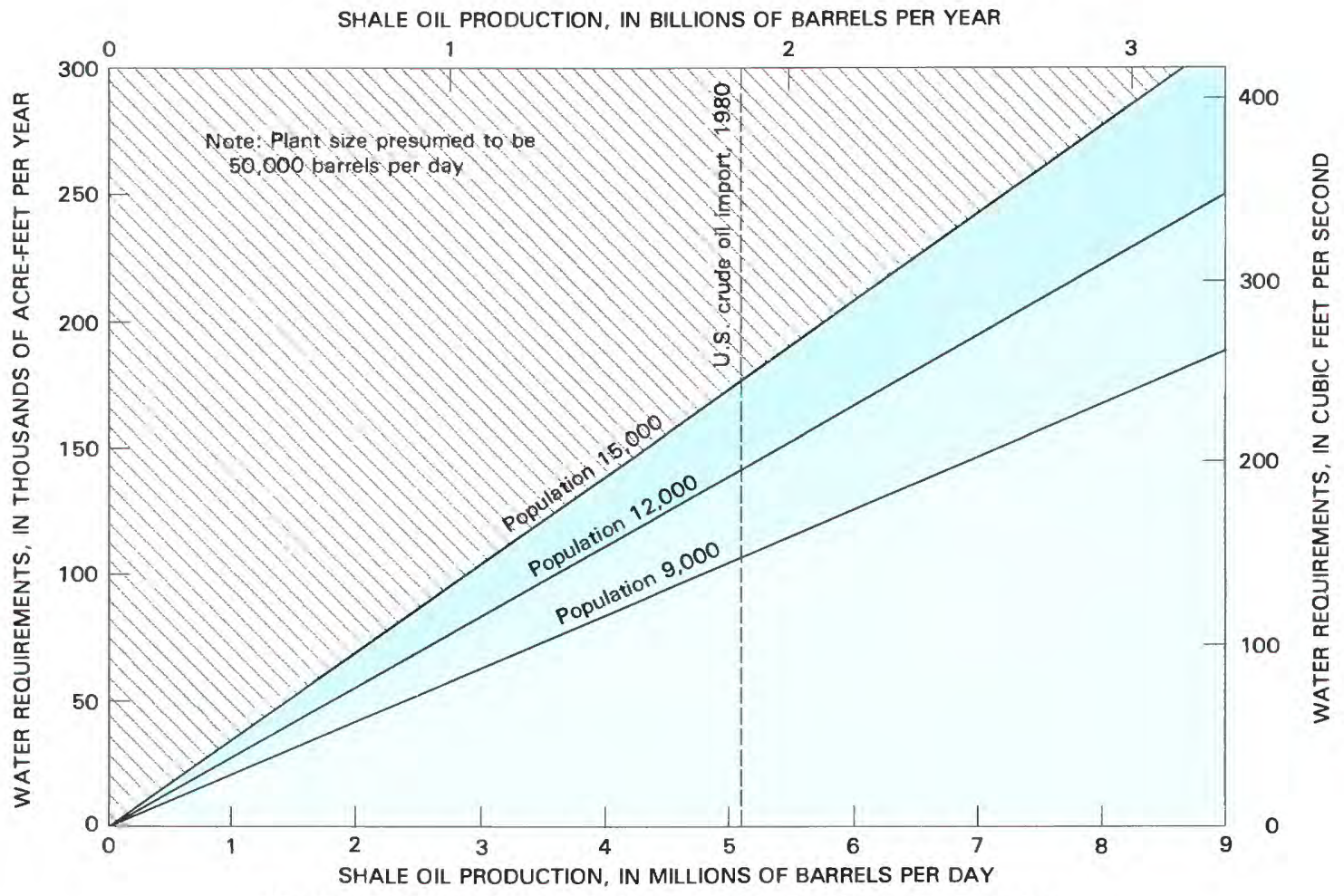

B. MUNICIPAL WATER REQUIREMENTS FOR SHALE-OIL PRODUCTION

Water requirements for shale-oil production (fig. 27). 
SHALE OIL PRODUCTION, IN BILLIONS OF BARRELS PER YEAR

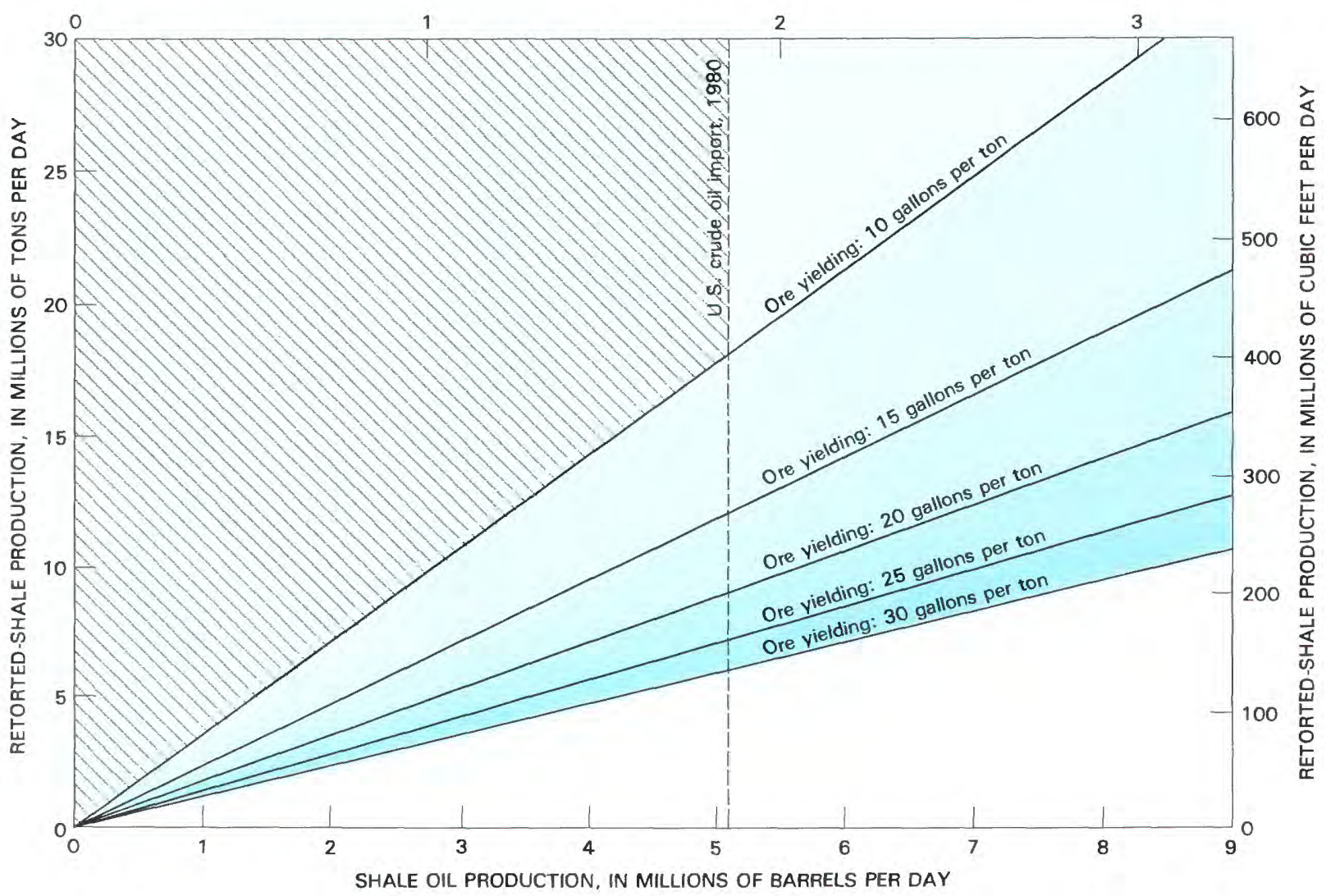

Retorted shale production (fig. 28).

1. Subsidence of the land surface would be reduced.

2. Additional oil-shale and other mineral resources could be recovered by mining the support pillars in underground mines.

3. The volume of retorted shale for disposal on the land surface would be decreased.

The disadvantages of backfilling are:

1. Mineral-development costs would be increased, unless the increased costs could be offset by increased productivity.

2. The retorted shale that was used as backfill could adversely affect the quality of ground water because it contains readily soluble materials. The problem could be minimized by reducing the leachability of the retorted shale.

Injection of water into abandoned mines may also reduce subsidence by providing support for the overlying materials. However, a water supply of suitable quality may not be available.

\section{SPOIL PILES OF RETORTED SHALE}

Large volumes of retorted-shale waste material will be produced by aboveground retorting. The volume produced depends on four main factors:

1. The total shale-oil production,

2. The average yield of the ore processed,

3. The density of the retorted shale, and

4. The particle size of the retorted shale.

The production of retorted shale for various rates of production and ore yields can be estimated, presuming that the retorting process consumes 15 percent of the original weight of the untreated shale, and the retorted shale is compacted to weigh about 90 pounds per cubic foot. Large volumes and weights of retorted shale will accumulate rapidly from high production rates and from development of lean ore.

Proper disposal of retorted-shale waste requires that the material be stable for many years. Retorted shale is saline and alkaline, contains few plant nutrients, and is more erodible than the original rock. The slow but inevitable processes 


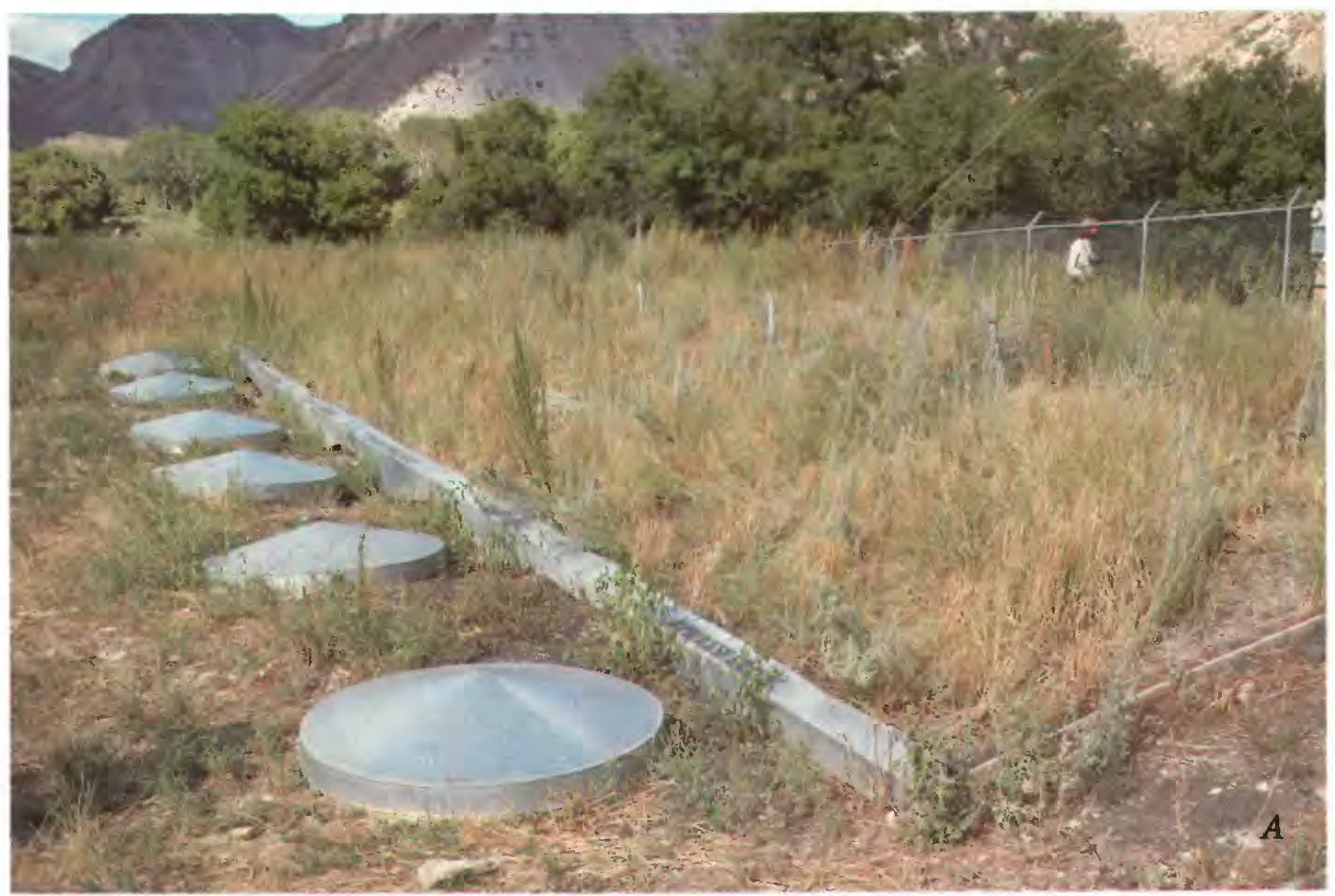

Revegetation of retorted shale at test plots. A, Instrumented plot operated by Union Oil Co near Parachute Creek. B, Test plots operated by Colorado State University between Yellow Creek and Ryan Gulch. Twelve inches of topsoil was added to plot on left; none was added to plot on right (fig. 29 above and facing page).

of weathering, erosion, leaching, and transport in streams eventually will allow the waste materials to migrate downstream in the Colorado River basin. The present concern is to ensure that the rate of waste removal by these processes is acceptable.

Nearby canyons and mesas have been proposed as sites for disposal of retorted shale from underground or surface mines. Sites near the heads of canyons appear to be acceptable because surface runoff from small upstream areas is limited and the erosion potential is low. Plans and limited onsite tests for the reclamation of spoil piles include removing and stockpiling soil or alluvial materials from the dump site, compacting retorted shale as it is placed on the pile, contouring the surface to minimize erosion, and covering the pile with soil and soillike material.

Uncertainties in the details of the optimal procedures for the reclamation of spoil piles of retorted shale include the amount of compaction required, the structural stability of the retorted-shale pile, the thickness and character of the cover materials, the potential for migration of soluble salts from the retorted shale upward into the plant-root zone, the maximum slope that is stable and can be revegetated, the degree to which rainfall and snowmelt will infiltrate and leach soluble materials from the retorted shale, the optimum vegetation types to achieve a permanent cover, and the need to irrigate the newly planted surface. Many short-term field tests of the physical and chemical stability of small areas of reclaimed retorted shale have met with various degrees of success. In general, the test results show a need for:

1. Compaction of the retorted shale to decrease its permeability,

2. Emplacement of 3 to 18 inches or more of soil or alluvial material cover,

3. Emplacement of coarse material between the retorted shale and the soil or alluvial material cover to decrease upward migration of soluble salts and discourage root growth, and

4. Maximum slopes of 4:1 to 5:1 for the surface of the pile. 


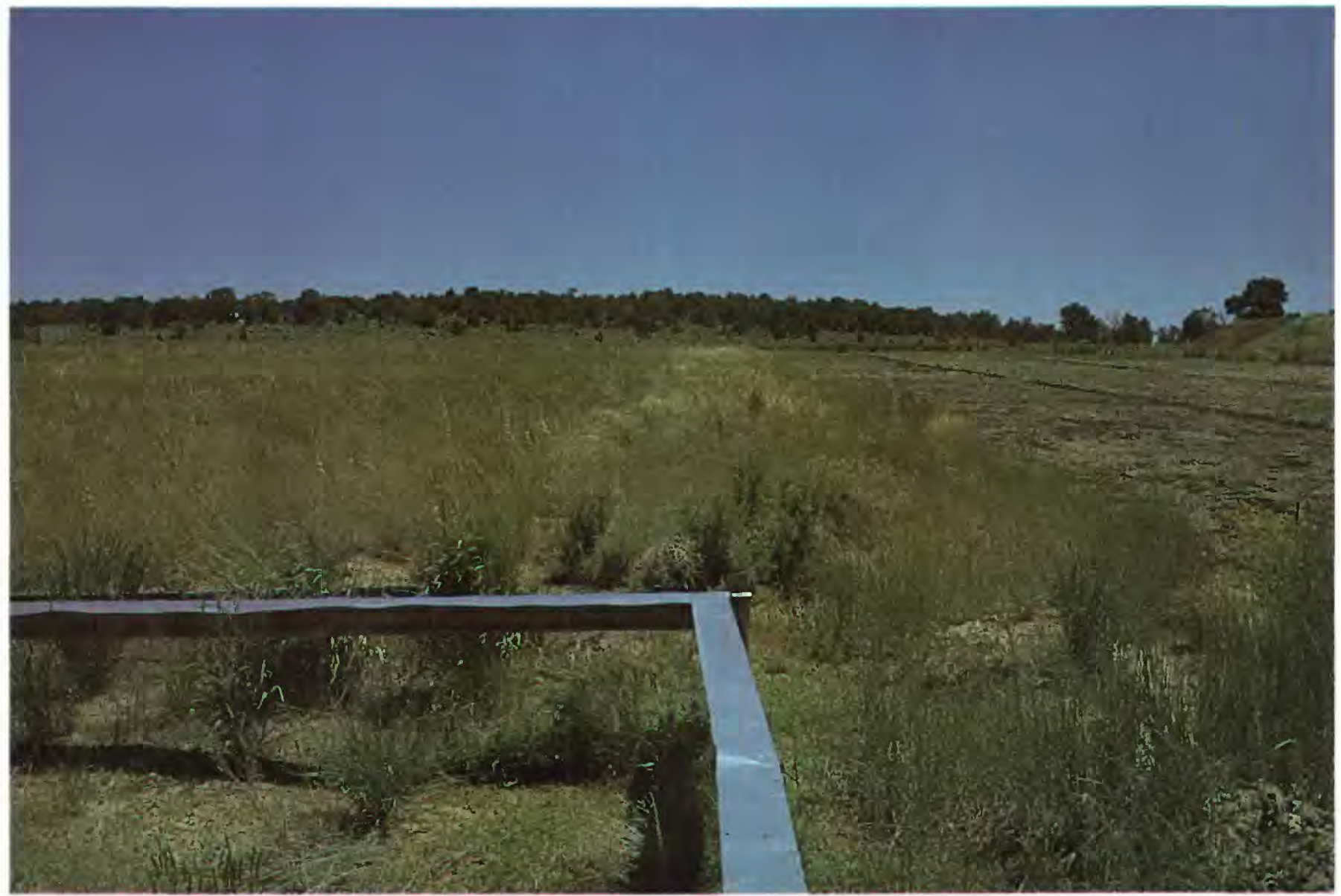

None of the onsite tests has been of adequate areal extent or duration to provide design details for the large pile that would result from commercial development.

Regardless of the methods used, a reclaimed spoil pile needs to have the following characteristics:

1. Plant growth must be present to decrease erosion, provide forage for livestock and wildlife, and preserve the natural landscape.

2. The erosion rate should be low enough that the rate of soil transport away from the pile is equal to or less than the rate of weathering and conversion of the underlying retorted shale to plant-supporting soil. Erosion rates measured locally in the Piceance basin have been as high as 0.1 inch per year.

3. The ability must exist to either convert the harmful constituents in retorted shale to harmless material, or to cause downward migration of the harmful constituents into the pile and immobilize them below the root zone.

Additional discussion of spoil piles is found in the chapter "Chemical effects and control of leachates from oil-shale spoil piles."
At surface mines, a variety of materials removed from the mine is available for reclamation by backfilling, including soil, alluvium, weathered rock, overburden rock, lean oil shale, and retorted shale. In backfilled zones, some subsidence and adverse effects on water quality may occur; the subsidence probably is less than in underground mined areas because the reclamation of open-pit mines can be more easily controlled. Many options are available for placement and control of the waste materials in a mined-out area. For example, the characteristics of the hydrologic system that develops in and on a backfilled pit can be controlled partly by design. These characteristics include surface runoff, ground-water recharge, ground water in storage, waterquality effects, erosion, and plant-growth potential for specific plant communities.

Retorted shale can be compacted in a bottom layer of low permeability that is covered by a more permeable layer of waste rock and overburden that is in turn overlain by a layer of sandy and silty soil, alluvial material, and topsoil. The surface can be sculpted into gentle slopes and revegetated to minimize erosion. Assuming that the present climatic conditions continue, this design would tend to minimize surface runoff, increase soil moisture, increase ground-water 
recharge, and minimize erosion. An alternative placement of backfilled material could increase surface runoff and decrease ground-water recharge. Other designs are also possible.

\section{IN SITU RETORTS}

In situ and modified in situ retorting methods cause special disposal problems because the retorted shale remains underground, and typically the retort is much more permeable than the surrounding rock. The mass of retorted shale that is abandoned in modified in situ retorts, such as that produced at an experimental site in Logan Wash, Colo., and at Federal lease tract $\mathrm{C}-\mathrm{a}$, presumably is permeable and contains readily leachable minerals. Laboratory tests and limited onsite tests indicate that the initial leachate from such retorts is alkaline and contains several tens of thousands of milligrams of dissolved salts per liter of water. This leachate is not a desirable addition to the local ground-water system, and several studies have been conducted on how to minimize its impact. Potential methods to control or minimize the leachate include:

1. Deliberate leaching of the retort prior to abandonment, collecting the leachate at the surface, and evaporating the leachate to produce a smaller, more manageable volume;

2. Grouting the retort by filling the open spaces between shale blocks with a cement slurry that is prepared using retorted shale;

3. Placing a grout curtain around the retort to isolate toxic substances from the ground water;

4. Creating a hydraulic bypass to minimize the groundwater flow through the retorted shale; and

5. Controlling retort conditions such as temperature in order to reduce the amount of material produced that could be deleterious to ground water.

Although all of the above methods would decrease the leachate problem, none has been evaluated using onsite tests.
Additional characteristics of in situ retorts are described in the chapter "Chemical effects and control of wastes from in situ retorts."

Little is known of the nature of shale that is retorted in situ under low temperatures, by steam, hot gas, or electromagnetic energy. However, the removal of the shale oil from the rock would tend to increase its permeability and would expose fresh surfaces of rock to leaching by ground water.

\section{REFERENCES}

Ashland Oil, Inc., and Occidental Oil Shale, Inc., 1977, C-b shale oil project, modification to detailed development plan, $89 \mathrm{p}$.

Ashland Oil, Inc., and Shell Oil Co., 1976, C-b shale project, detailed development plan and related materials, $2 \mathrm{v}$.

Golder Associates, 1977, Water management in oil shale mining: U.S. Bureau of Mines Open-File Report 278, 2 v.; prepared under U.S. Bureau of Mines contract T0265019.

Gulf Oil Corp., and Standard Oil Co. (Indiana), 1976, Detailed development plan, tract $\mathrm{C}-\mathrm{a}, 3 \mathrm{v}$.

1977, Revised detailed development plan, tract $\mathrm{C}-\mathrm{a}, 3 \mathrm{v}$.

Hendrickson, T. A., compiler, 1975, Synthetic fuels data handbook: Denver, Cameron Engineers, Inc., 297 p. and appendix.

Miller, G. A., 1981, Water availability and requirements for western oil shale development, in Environmental and economic considerations in energy utilization: Ann Arbor, Mich., Proceedings of the Seventh $\mathrm{Na}$ tional Conference on Energy and the Environment, p. 44-49.

Russell, P. L., 1979, History of western oil shale: East Brunswick, N.J., The Center for Professional Advancement, $152 \mathrm{p}$.

U.S. Bureau of Land Management, 1975, Final environmental impact statement, proposed development of oil shale resources by Colony Development Operation in Colorado, $2 \mathrm{v}$.

U.S. Bureau of Reclamation, Upper Colorado Region, 1974, Alternative sources of water for prototype oil shale development, Colorado and Utah, $115 \mathrm{p}$.

U.S. Department of the Interior, 1973, Final environmental statement for the prototype oil shale leasing program, $6 \mathrm{v}$.

Mine stability and the occurrence of ground water are partly controlled by the joint patterns of the Green River Formation. These joint patterns and their significance are discussed in the following chapter. 
RELATIONS AMONG THE GEOLOGIC, HYDROLOGIC, AND GEOCHEMICAL CHARACTERISTICS OF THE BASIN 
. 


\title{
SYSTEMATIC JOINTS WITHIN OIL SHALES AND ASSOCIATED ROCKS OF THE GREEN RIVER FORMATION
}

\author{
BY EARL R. VERBEEK and MARILYN A. GROUT
}

Nearly all rocks exposed at Earth's surface contain numerous joints-naturally occurring fractures that break a once-solid rock mass into a series of smooth-sided blocks. Sizes of such joint-bounded blocks span a broad range; blocks from one-half to several feet on a side are typical of many areas, including the Piceance basin. A small outcrop of rock thus may contain hundreds of joints, and a mine may contain millions-yet joints in the Piceance basin received only scant attention until 1979-81 when the joint sets described here were identified. Extended studies of these joints are described in reports listed in the references at the end of this chapter. The importance of joints to the oil-shale industry stems from two facts:

1. Joints are the primary conduits through which ground water flows beneath the basin.

2. Joints impair the stability of any manmade cut in rock, whether at the surface or underground.

\section{HYDROLOGIC ASPECTS OF JOINTS}

Processing of oil shale will create increased demands for water in the Piceance basin. Costly importation of water from outlying areas could be minimized if nearby sources of ground water were identified and tapped. Successful development of the basin's ground-water resources hinges on an adequate understanding of water flow through the various regional ground-water reservoirs which are discussed in the chapter "Paleozoic and Mesozoic formations and their potential as ground-water reservoirs." On a more local scale, drainage of underground mines and in situ retorts and the disposal of waste water from both sources pose their own special concerns. Drainage of a mine area, for example, might reduce the yield of nearby water wells. Disposal of the water by injection could have adverse effects on water quality in nearby streams and in wells drilled for drinking water. Here, too, an understanding of ground-water flow through fractured rocks is necessary to optimize locations of new wells and to predict their effects on existing wells and streams.

The flow of ground water beneath the Piceance basin is most conveniently envisioned as taking place through three types of openings in rock:

1. Primary voids, which are small pores and hairline cracks between individual mineral grains;
2. Secondary voids created by the dissolution of watersoluble minerals by ground water; and

3. Joints, whose opposing walls commonly are separated slightly and permit the passage of water.

Primary voids in oil shale transmit water only at exceedingly slow rates, both because the openings are so minute and because many of them are clogged with kerogen, the solid hydrocarbon that liberates shale oil upon heating. Intact oil shale thus is one of the least permeable rocks in northwestern Colorado. Secondary permeability has resulted wherever ground water has removed the water-soluble minerals nahcolite and halite, leaving behind a highly porous oil-shale rubble. Such rubble transmits water freely but is of restricted occurrence within the Green River Formation because most of the formation lacks significant quantities of water-soluble minerals. Joints, in contrast, occur throughout the Green River Formation, where they increase permeability and storage and influence flow paths of ground water. Of the three general types of water-transmitting openings in the oil shales, joints are the principal conduits for ground-water flow at shallow to intermediate depths. Accordingly, local joint networks can be expected to affect the yield of water wells, the way in which mine drainage affects wells and streams, and the suitability of other wells for injecting waste water into aquifers. Water movement within the fractures and pores of the aquifers associated with oil shale also is discussed in the chapter "Hydrologic system of the Piceance basin."

\section{ENGINEERING ASPECTS OF JOINTS}

The success of mining oil shale by any method will depend to some extent on an adequate understanding of the joint network at the site. Where shale oil is to be recovered from an in situ retort, for example, preexisting fractures will:

1. Affect the ease of properly rubblizing the rock in the retort and affect the size and shape of the resultant blocks;

2. Affect hydraulic connection between the retort and recovery wells for hydrocarbons liberated from the burning shale; and

3. Control the transport, by ground water, of leachates from the retorted shale. 
Joints in underground mines provide numerous entries for water and hazardous gases into the mine workings. Highcapacity pumps and added ventilation equipment may be necessary where workings intersect zones of closely spaced joints. Rock stability may be a problem in these same areas; for example, pillars may have only a fraction of their design strength if they contain large, inclined joints. However, the cost of excavating rock in some underground mines may be decreased if the mine is designed to take maximum advantage of the natural fracture network.

Joints at the land surface are of lesser consequence; their chief effect is to reduce the stability of manmade cuts in rock, locally to the point of collapse. Small rockfalls of several or more joint-bounded blocks are common along roadcuts, especially during the cooler months when alternate freezing and thawing of water within joints wedge the rock apart. Collapse of larger volumes of rock is possible wherever the rock is weakened by closely spaced joints, particularly where many joints are parallel to or dip toward the free face of an excavation. Local modifications of the design of open-pit mines may be advisable where fracture patterns could jeopardize safety.

\section{PRELIMINARY STUDIES OF JOINTS INDICATE SYSTEMATIC PATTERNS THAT ARE SIGNIFICANT TO HYDROLOGY AND MINING}

Joints of diverse orientation within the same exposure are usual and commonly impart to the rock a somewhat chaotic or randomly broken appearance. Closer inspection of the exposures, however, generally reveals that the orientations of the joints, although diverse, are also highly systematicthat is, that the rock is fractured in a definite pattern that can be recognized and traced from one exposure to another. Joints commonly occur in sets-groups of parallel or nearly parallel fractures of similar appearance and presumably common origin. Work is now in progress to determine the relative sequence of joint-set development at more than 350 localities, to correlate joint sets from one locality to another, and thus ultimately to determine the fracture history of the Piceance basin in considerable detail. This discussion gives some preliminary results from the ongoing study of exposures of the Green River Formation in the northern part of the Piceance basin.

Eight sets of joints have been recognized within rocks of the Green River Formation in the Piceance basin. Joints of each set have characteristic orientations, sizes, spacings, ages, surface markings, and mineral coatings, and they can be distinguished from joints of other sets by these features. Two to four sets of joints, unequally developed, are present in most exposures of the Green River Formation. No exposure contains all eight sets.

The term joint is restricted by some to those fractures that simply have opened slightly. Other fractures along which slip has occurred, and the opposing walls of the fracture have ground against each other, are more properly termed faults. However, faults along which the amount of slip is negligibly small, less than one inch, commonly are grouped with joints for descriptive purposes. We will follow that convention in this paper.

Joint sets are here referred to by the letter $F$ (for fracture), followed by a subscript that indicates the relative age of the set; $F_{1}$ is the oldest set. Thus, joints of the third period of systematic fractures to have formed within the oil shales of the Green River Formation are referred to simply as $F_{3}$ joints. If two or more sets formed during the same period, they will be denoted $F_{3 A}, F_{3 B}$, etc. Noteworthy features of each joint set are mentioned briefly below and are entered in condensed form in table 3. Readers not interested in the descriptions of specific sets may wish to skip to the summary section on page 49 .

\section{JOINT SETS $F_{1 A}$ AND $F_{1 B}$}

Joints inclined to the sedimentary layers at angles of about 50 to $70^{\circ}$ were the first systematic fractures to form in parts of the Green River Formation. In most places, the $F_{1 A}$ and $F_{1 B}$ joints trend northwest to north, but north north-easterly trends have been noted locally. Some of the joints $\left(F_{1 A}\right)$ dip to the northeast or east, whereas others $\left(F_{1 B}\right)$ dip to the southwest or west. The two sets are of the same age; at many outcrops it can be shown that $F_{1 A}$ and $F_{1 B}$ joints developed almost simultaneously in the same layer.

The distribution of $F_{1 A}$ and $F_{1 B}$ joints within oil shales of the Green River Formation is patchy. Locally, however, they dominate the joint pattern of the oil shales to the virtual exclusion of other sets. A third set, vertical $F_{1 \mathrm{C}}$ joints, have been found in a few places but are so uncommon that they will not be discussed here.

The $F_{1 A}$ and $F_{1 B}$ joints are small-scale normal faults that record breakage of the oil shales under the weight of overlying, younger sediments. Beds of oil shale commonly are offset a few tenths of an inch along $F_{1 A}$ and $F_{1 B}$ joints, whose surfaces locally bear minute scratches that formed as the two walls of each joint slipped against each other. The slight slip of one joint wall relative to the opposing wall opened a series of voids along some of the $F_{1 A}$ and $F_{1 B}$ joints that, as a result, are locally important conduits for ground-water flow. Entry of water into mine workings and decreased rock strength are likely where $F_{1 A}$ and $F_{1 B}$ joints are closely spaced.

\section{JOINT SET $\boldsymbol{F}_{2}$}

West- to northwest trending vertical $F_{2}$ joints, the dominant fractures of the Green River Formation, are present in nearly all outcrops. The $F_{2}$ joints are the best developed of all sets in most exposures and typically are most abundant 


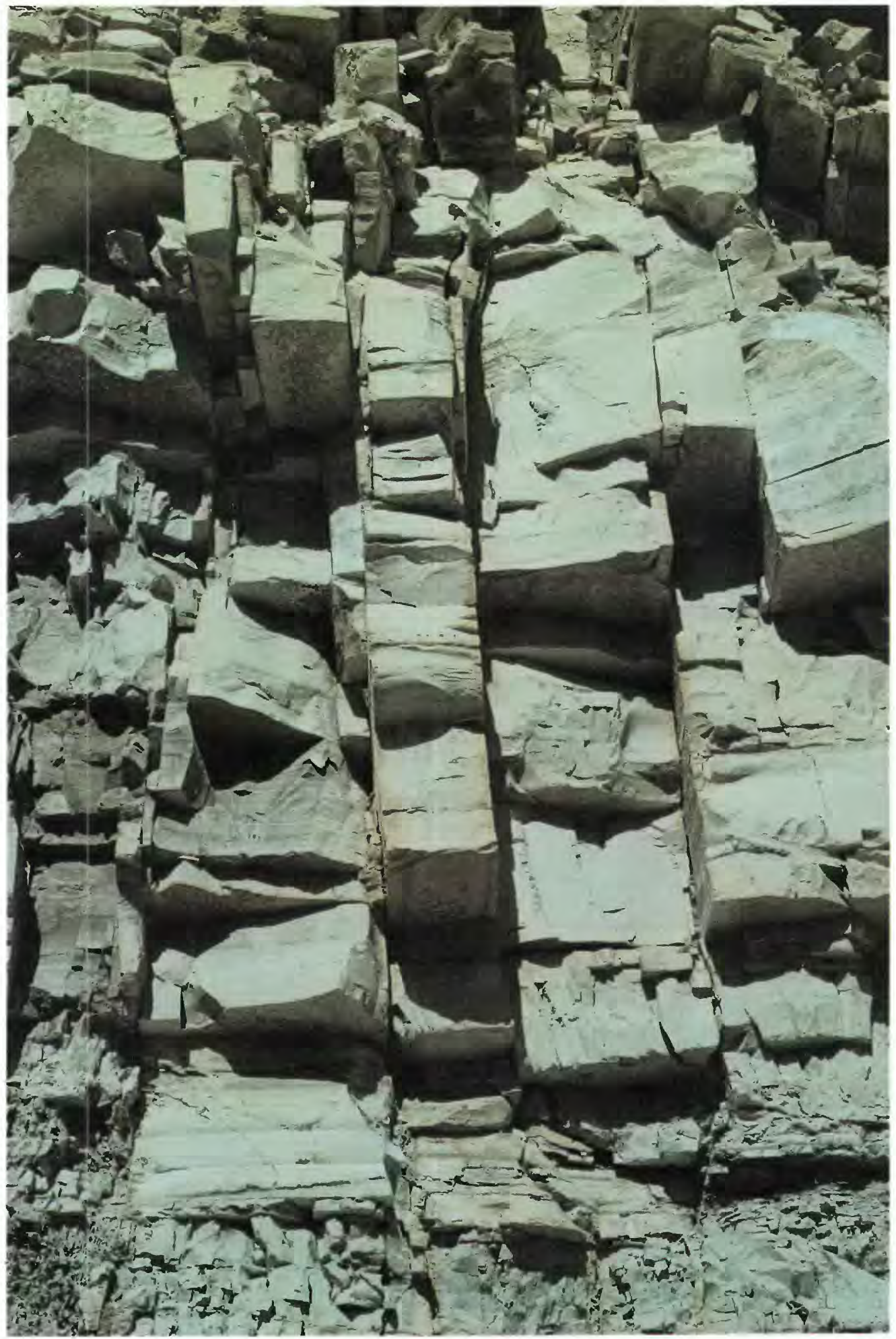

A well-developed set of joints, with an average spacing of about one foot, within moderate-grade oil shales of the Piceance basin (fig. 30). 


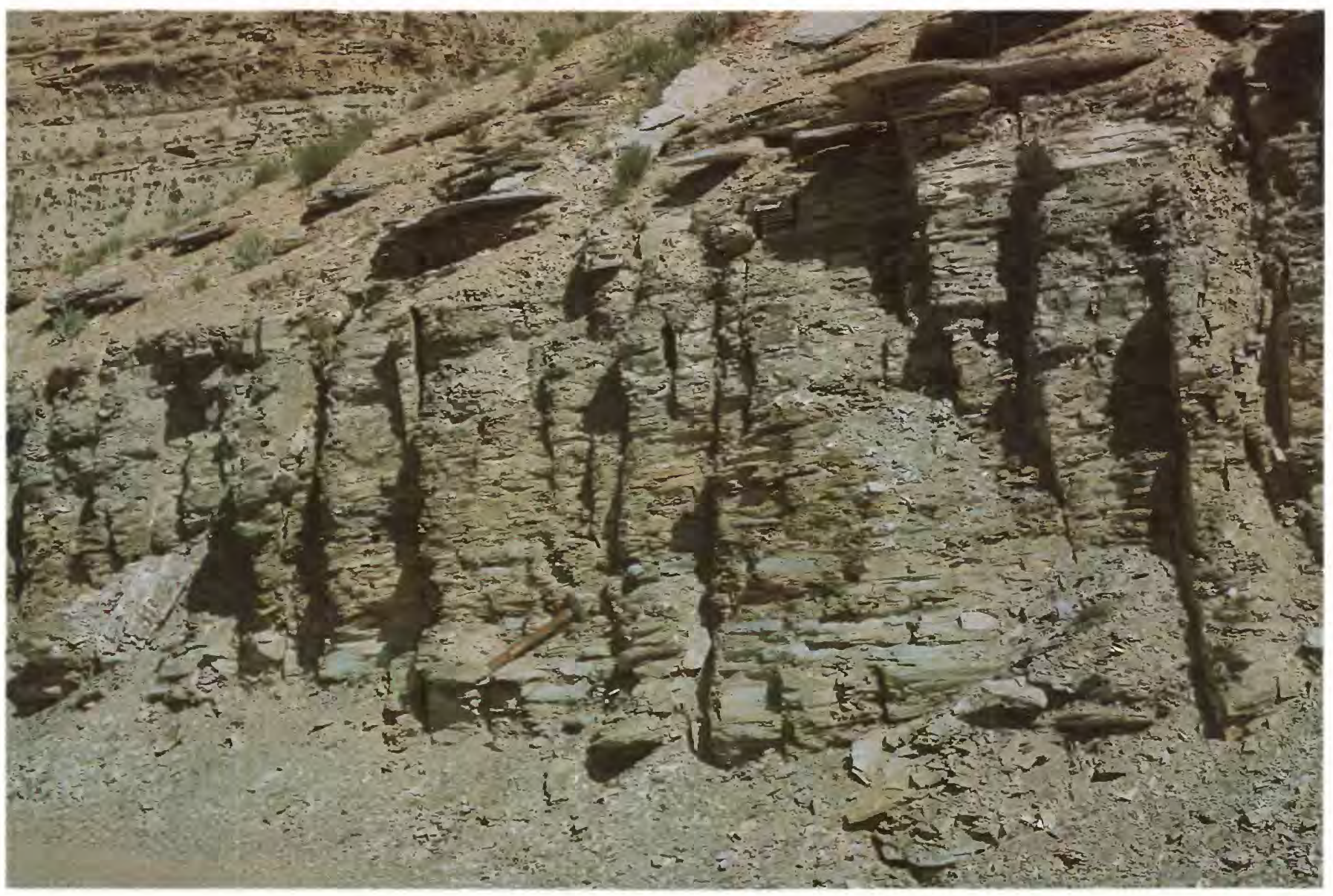

A set of $F_{2}$ joints in moderately rich oil shales near the mouth of Piceance Creek (fig. 31).

in marlstones and in the lean oil shales. Joint spacings-the distance between adjacent joints - may average 3 inches or less in these lean beds, but spacings increase with greater richness of the oil shales. Spacings from 1.5 to 5 feet are common within many beds of moderate richness; spacings of 10 feet or more are typical of the richest beds.

Many $F_{2}$ joints in surface exposures are open - that is, the opposing walls of each joint are separated about 1/16 to $1 / 8$ inch. Evidence for past ground-water movement through these open fractures is abundant: the oil shales commonly are bleached (oxidized) to a tan color adjacent to $F_{2}$ joints (fig. 30), the joint walls themselves locally are deeply pitted and corroded (even in unweathered, manmade exposures), and the walls of some $F_{2}$ joints are plated with calcite precipitated from the circulating ground water. Joints of other sets are much less open and show only minimal effects of ground-water flow through them. By analogy, present-day ground-water flow through bedrock may take place mostly along $F_{2}$ joints at depth. Zones of closely spaced $F_{2}$ joints thus are promising areas for high-yield water wells, but the same zones may present problems of rapid ground-water flow into underground-mine workings.

Typical $F_{2}$ joints have large surface areas, cut several or more beds in the vertical direction, and extend laterally for tens of feet. The $F_{2}$ joints are planes of weakness along which slabs of rock readily separate. Road cuts with free faces parallel to $F_{2}$ joints may be marginally stable; some have already collapsed. The stability of underground excavations may likewise be weakened by large and closely spaced $F_{2}$ joints. 


\section{JOINT SETS $\boldsymbol{F}_{3 A}$ AND $\boldsymbol{F}_{3 B}$}

The $F_{3 A}$ and $F_{3 B}$ joints appear to be restricted to the southern part of the Piceance basin; they have not yet been found in rocks exposed in the drainage areas of Piceance and Yellow Creeks. Little is known of these joints because they have been studied within only a small area of the Roan Plateau. Their characteristics as outlined here thus may not be typical of these joints in other areas.

The $F_{3 A}$ and $F_{3 B}$ joints are large fractures; surface areas of more than 100 square feet are common. Like the $F_{1 A}$ and $F_{1 B}$ joints, they appear to have developed virtually simultaneously as two sets of fractures inclined to the sedimentary layers. Lateral variations in the spacing of $F_{3 A}$ and $F_{3 B}$ joints are slight within the small area studied, but differences in spacing from bed to bed are pronounced and abrupt. The $F_{3 A}$ and $F_{3 B}$ joints are best developed in rich oil shales but are absent, or sparse, in lean oil shales, marlstones, and sandstones. Studies of joints in surface exposures thus are of uncertain value in predicting the spacing, or even the existence, of $F_{3 A}$ and $F_{3 B}$ joints in different rocks at depth.

The large, inclined surfaces of $F_{3 A}$ and $F_{3 B}$ joints may seriously weaken pillars, roofs, and some walls in underground mines. The collapse of excavated faces in mines, along roads, and in open cuts is possible wherever the $F_{3}$ trend is nearly parallel to the cut face, and particularly where the joint set dipping toward the face is well developed or undercut.

\section{JOINT SET $\boldsymbol{F}_{4}$}

Joints of this set are among the most common in the $\mathrm{Pi}$ ceance basin. The $F_{4}$ joints generally are small, and few cut more than one bed. They are second only to $F_{2}$ joints in abundance and are developed throughout an equally large area. Like $F_{2}$ joints, $F_{4}$ joints generally are abundant in lean oil shales and become progressively more widely spaced in richer beds. The trend of the $F_{4}$ joint set gradually changes orientation from nearly due north at Rio Blanco to northeast at the mouth of Piceance Creek; the $F_{4}$ joints thus are nearly perpendicular to $F_{2}$ joints in most places. The $F_{4}$ joints probably facilitate movement of ground water through bedrock by providing permeable cross-linkages between adjacent $F_{2}$ joints, presumably the main conduits for groundwater flow.

\section{JOINT SET $\boldsymbol{F}_{5}$}

The $F_{5}$ joints are nearly parallel to $F_{2}$ joints and hence are readily confused with them. However, $F_{5}$ joints do not extend from one bed into another, are younger than $F_{4}$ joints, and show little evidence of past ground-water flow (the surfaces of $F_{5}$ joints are fresh and are not lined with calcite). The $F_{5}$ joints are much less abundant and open than $F_{2}$ joints.

\section{PATTERNS OF THE EIGHT JOINT SETS CAN BE SUMMARIZED}

Eight sets of joints have been recognized to date within rocks of the Green River Formation in the Piceance basin. Only two of the eight sets occur throughout the formation, thus dominating the joint pattern in most parts of the basin. The joints of five other sets are only locally common, and the joints of one set are small and insignificant.

The two dominant sets trend generally west-northwest to northwest $\left(F_{2}\right)$ and north-northeast to northeast $\left(F_{4}\right)$, forming a nearly perpendicular network of joints on a regional scale. Shapes of joint-bounded blocks are determined by the relative abundance of members of each set, and range from northwest-trending vertical slabs (as shown in the photographs) where $F_{4}$ joints are sparse, to vertical prisms where $F_{4}$ joints are abundant. This simple fracture pattern locally is modified by joints of other sets, but only rarely are more than four sets present in the same outcrop.

The $F_{2}$ and $F_{4}$ joints probably dominate the fracture pattern of the buried oil shales of the basin interior as thoroughly as they do the exposed rocks along the basin rim. It is likely that the flow of ground water beneath the Piceance basin is influenced strongly by the distributions, sizes, spacings, openings, and interconnections of $F_{2}$ and $F_{4}$ joints. Ground water within any particular bed thus will flow more readily in some directions than others-that is, horizontal permeabilities are strongly direction dependent in fracture-controlled aquifers. The direction of greatest horizontal permeability within a bed will not necessarily be parallel to the joints of either set. 


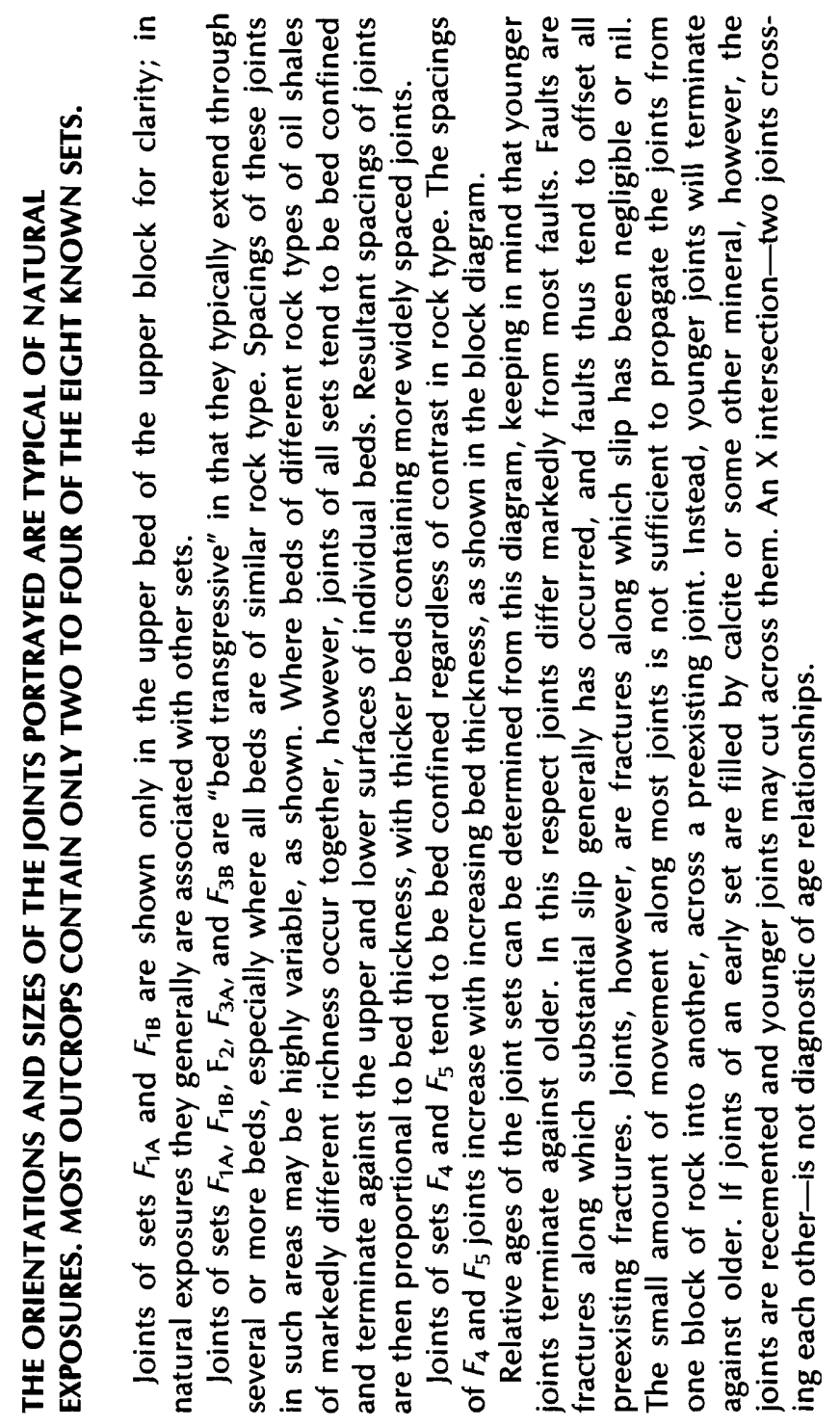




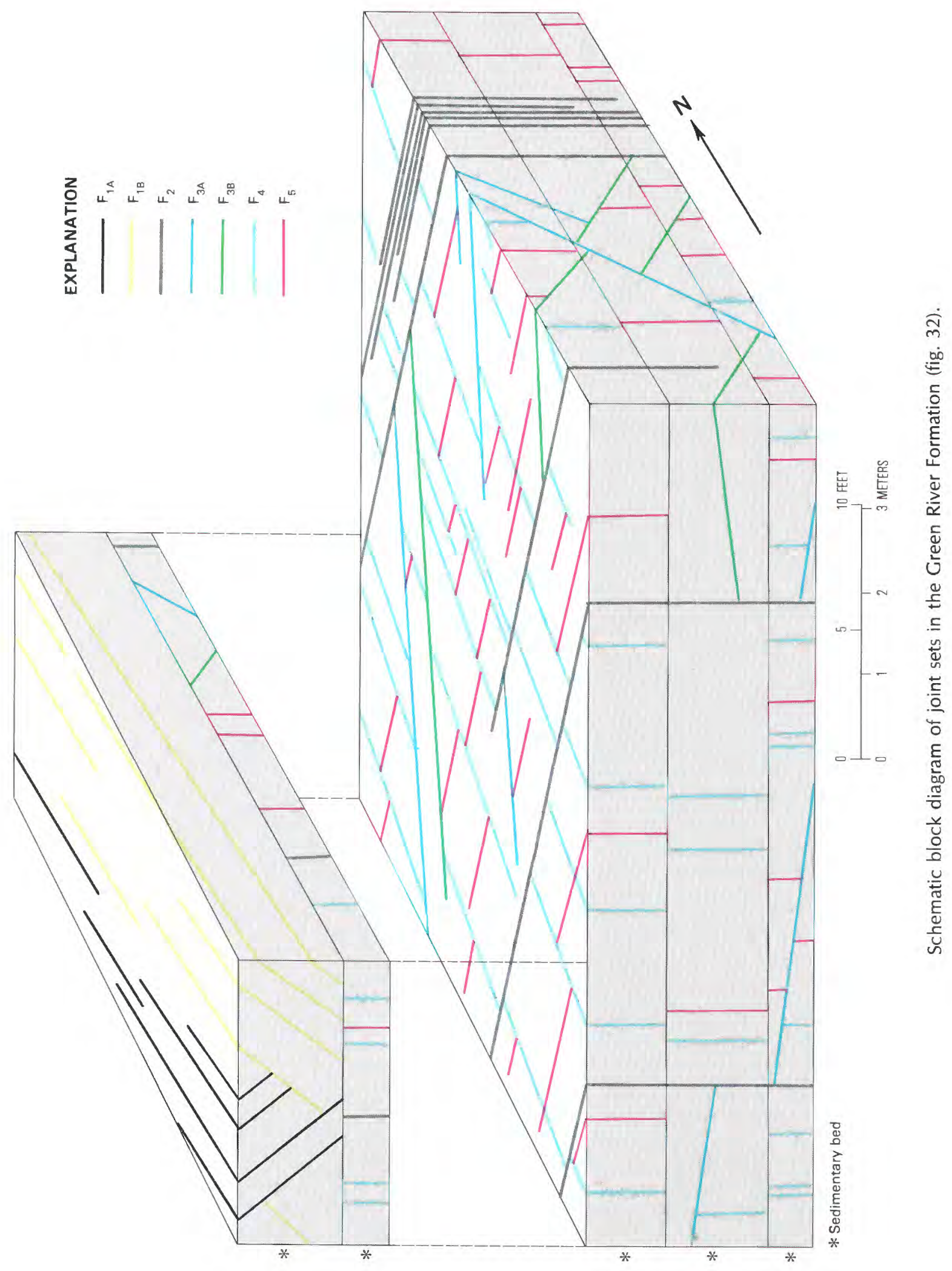




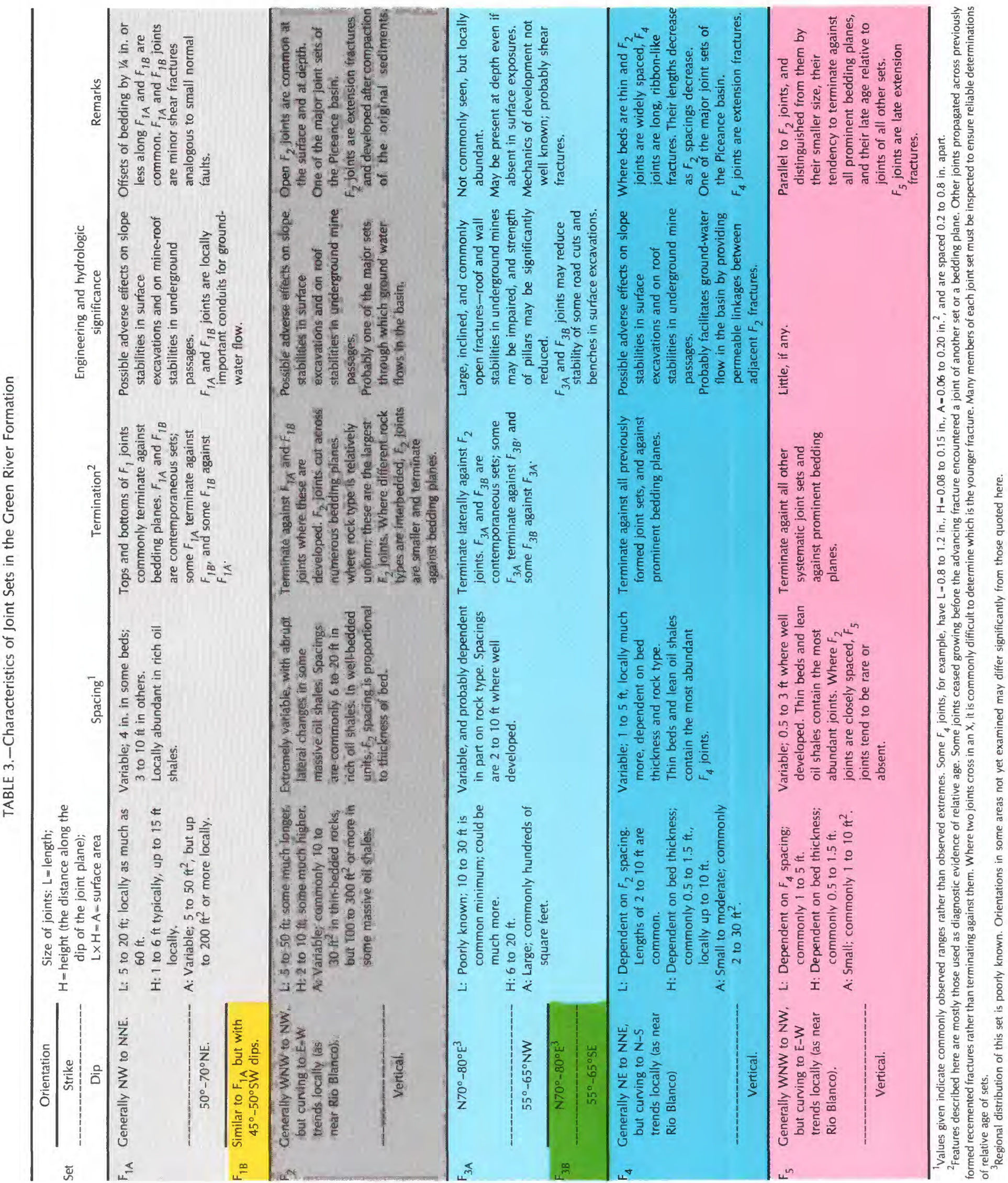




\section{JOINT SPACING DEPENDS UPON BED THICKNESS, ROCK TYPE, AND DEPTH BELOW LAND SURFACE}

Bed thickness, rock type, and depth below the surface significantly affect the spacing of joints within rocks of the Green River Formation.

\section{BED THICKNESS}

For any given rock type, the spacing of joints in different beds of the same outcrop generally can be shown to be proportional to bed thickness - thicker beds contain more widely spaced joints. Measurements of average joint spacing within selected beds of different thickness commonly are portrayed on a graph, from which spacings of joints in all other beds of the same rock type can be predicted. Several such graphs, one for each rock type, can then be used to predict spacings of joints in unexposed rocks in advance of mining, if bed thickness and rock type are first determined from a drill core, which is a routine exercise. Complications that restrict the effectiveness of this simple procedure include changes in the relation between spacing and thickness that occur from set to set, from one locality to another, and with depth. Additional spacing measurements, for each joint set and at multiple localities, will remove or compensate for most such difficulties.

\section{ROCK TYPE}

Some effects of rock type on joint spacing already have been mentioned. For example, both $F_{2}$ and $F_{4}$ joints become progressively more widely spaced with increasing richness of oil shale. The dependence of joint spacing on rock type can be measured directly, and most accurately, only where different rock types occur together in beds of equal or similar thickness. In most places, however, the effect of variations in joint spacing due to differences in bed thickness must be calculated before spacings among different rock types can be compared.

\section{DEPTH BELOW LAND SURFACE}

Once the dependence of joint spacing on bed thickness and rock type is known, it should be possible to define the relationship between joint spacing and depth below the sur- face. Little is yet known, however, about the effect of depth on joint spacing in the Piceance basin, except that rocks at increasing depths generally contain fewer and more tightly closed joints. Measurements within one oil-shale mine revealed a 250-percent increase in joint spacing within a vertical interval of 500 feet, but the rate at which joint spacings increase with depth is likely to vary from one part of the basin to another.

Based on the above criteria, the fewest joints should be found in the most thickly bedded and richest oil shales at depth - for example, in the Mahogany zone. Even at the surface, where these same rocks are exposed as the Mahogany ledge, it is apparent that the massive and rich oil shales generally contain far fewer joints than any other rock unit. The paucity of joints in these rocks is reflected in their tendency to retard vertical mixing of ground water circulating above and below them, and it has led to the conventional recognition of an upper and lower series of bedrock aquifers separated by the less permeable Mahogany zone, all of which are discussed in the chapter "Hydrologic system of the Piceance basin." As with any other generality, however, exceptions to this simple subdivision are expected and found. In some parts of the basin, as along segments of Cathedral Bluffs on the western side of the basin, joints within the Mahogany zone are both large and abundant. Here the Mahogany zone may transmit water readily, and a distinct series of upper and lower bedrock aquifers probably does not exist.

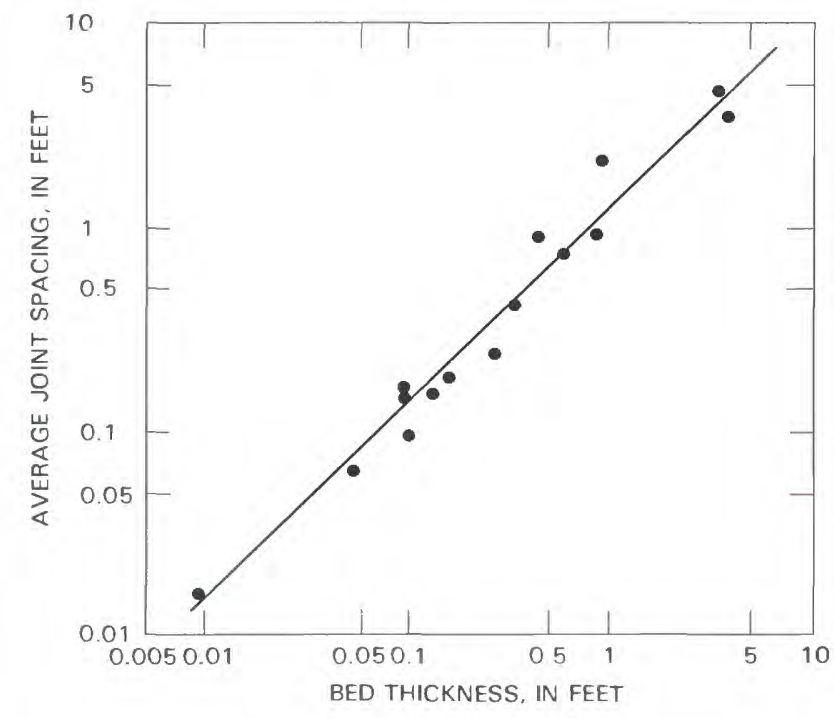

Relation between spacing of $F_{2}$ joints and bed thickness for fine-grained sandstones and siltstones of the Green River Formation near Rio Blanco (fig. 33). 


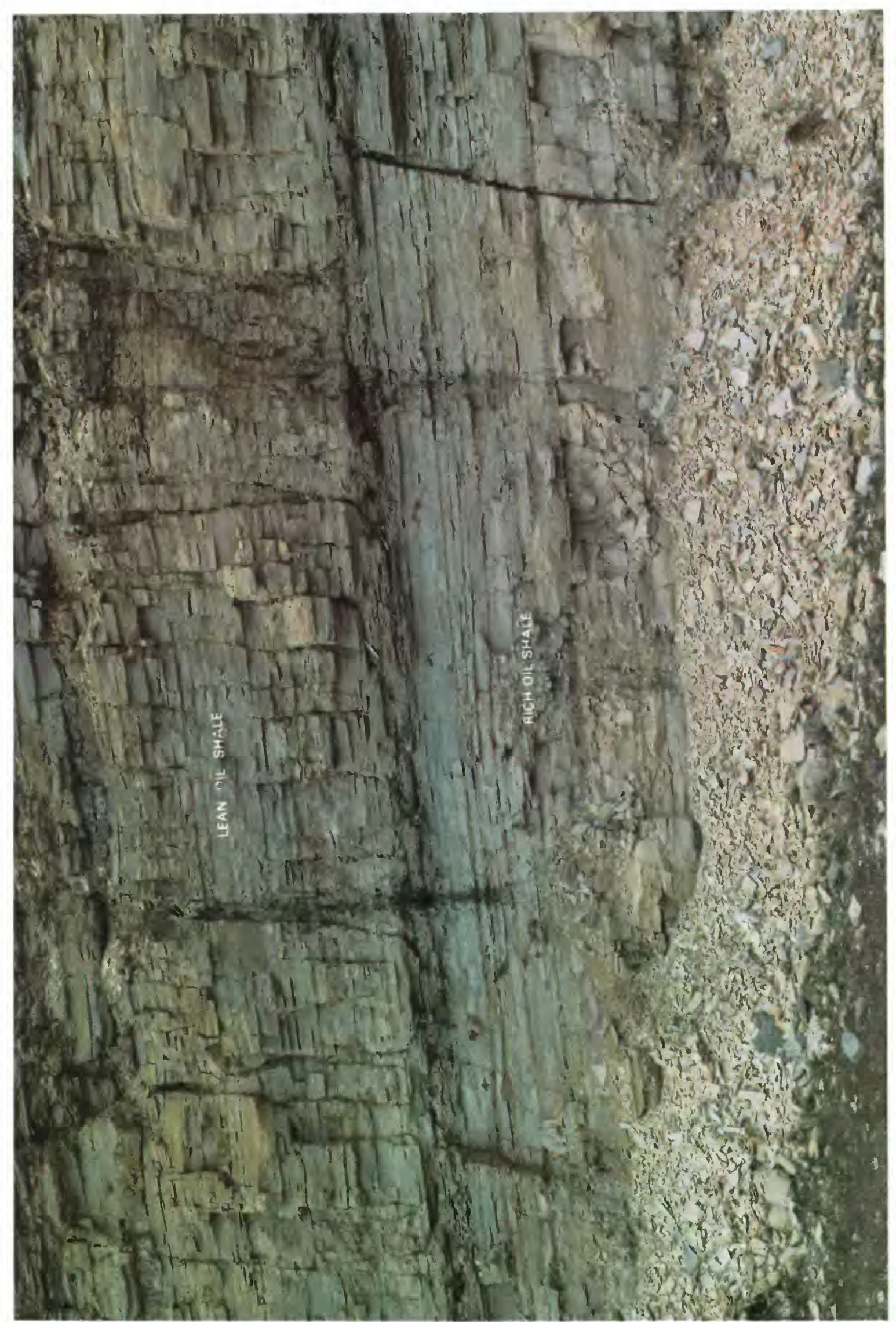




\section{REFERENCES}

Grout, M. A., and Verbeek, E. R., 1983, Field studies of jointsinsufficiencies and solutions, with examples from the Piceance Creek basin, Colorado, in Gary, J. H., ed., Proceedings, 16th Oil Shale Symposium: Colorado School of Mines Press, Golden, Colorado, p. 68-80.

Kelley, V. C., and Clinton, N. J., 1960, Fracture systems and tectonic elements of the Colorado Plateau: University of New Mexico Publications in Geology, no. 6, 104 p.

Smith, R. S., 1980, A regional study of joints in the northern Piceance basin, northwest Colorado: Golden, Colorado School of Mines M.S. thesis, $126 \mathrm{p}$.

Smith, R. S., and Whitney, J. W., 1979, Map of joint sets and airphoto lineaments of the Piceance Creek basin, northwestern Colorado: U.S Geological Survey Miscellaneous Field Studies Map MF-1128, scale 1:100,000.

Verbeek, E. R., and Grout, M. A., 1983, Fracture history of the northern Piceance Creek basin, northwestern Colorado, in Gary, J. H. (ed.), Proceedings, 16th Oil Shale Symposium: Colorado School of Mines Press, Golden, Colorado, p. 26-44.
Verbeek, E. R., and Grout, M. A., 1984, Fracture Studies in Cretaceous and Paleocene strata in and around the Piceance basin, ColoradoPreliminary results and their bearing on a fracture-controlled natural gas reservoir at the MWX site: U.S. Geological Survey Open-File Report 84-156, $30 \mathrm{p}$.

Verbeek, E. R., and Grout, M. A., 1984, Prediction of subsurface fracture patterns from surface studies of joints-An example from the Piceance Creek basin, Colorado, in Spencer, C. W., and Keighin, C. W., (eds.), Geologic studies in support of the U.S. Department of Energy's Multiwell Experiment, Garfield County, Colorado: U.S. Geological Survey OpenFile Report 84-757, p. 76-86.

Grout, M. A., and Verbeek, E. R., 1985, Fracture history of the Plateau Creek and adjacent Colorado River valleys, southern Piceance basinImplications for predicting joint patterns at depth: U.S. Geological Survey Open-File Report 85-744, 17 p.

Unconsolidated sedimentary deposits overlie the bedrock framework of the Piceance basin. Some of these deposits are associated with the stream system. A discussion of alluvial and fan deposits of unconsolidated material follows. 



\title{
UNCONSOLIDATED DEPOSITS OF THE PICEANCE BASIN
}

\author{
By FRANK A. WELDER
}

A variety of alluvial deposits has been emplaced in the Piceance basin during the last 10,000 years. Most of these deposits lie in stream valleys between the stream channel and the bedrock. The alluvial deposits affect the characteristics of the stream and the interchange of water between the stream and the bedrock aquifers. Permeable and saturated alluvial deposits are valley-fill alluvial aquifers from which a water supply can be obtained. An understanding of the alluvial deposits is needed in order to assess their effects on the hydrologic system in the basin under natural conditions and under conditions of mineral development, including mine drainage.

\section{ALLUVIAL AND FAN DEPOSITS FILL THE STREAM VALLEYS}

The valleys of the Colorado and the White Rivers and their tributaries are partly filled with alluvial deposits and fan deposits. These sediments were deposited by water in the Holocene Epoch of the Quaternary Period (see table 1). East of Meeker, the alluvium in the White River valley is more than 100 feet thick and supplies ground water through wells to the city. Exploratory drill holes also have penetrated varied thicknesses of saturated alluvium in the valleys of Roan, Parachute, Piceance, and Yellow Creeks.

Test holes in alluvium of Roan Creek about 5 miles upstream from De Beque (section $A-A^{\prime}$ ) penetrated about 80 feet of saturated permeable sand and gravel. On Parachute Creek about 3 miles upstream from Parachute (section $B-B^{\prime}$ ), test holes penetrated about 70 feet of saturated permeable sand and gravel.

In the alluvium of Piceance Creek, test holes drilled upstream from the confluence of Willow Creek (section $C-C^{\prime}$ ) penetrated about 70 feet of saturated permeable sand and gravel. However, about 8 miles further downstream at the junction of Piceance Creek and Ryan Gulch (section $D-D^{\prime}$ ), test holes drilled in Piceance Creek valley penetrated dark gray to blue, dense organic clay as much as 70 feet thick, extending across most of the valley. At the junction between the two stream valleys, a spring flows at a rate of about 150 gallons per minute. The water emerges from the valley floor at the contact with the bedrock that forms the valley wall.

Westward in Yellow Creek valley (section $E-E^{\prime}$ ), test holes penetrated 35 to 45 feet of saturated sand and gravel. About 5 miles downstream from this location and immediately upstream from the junction with Barcus Gulch (section $F-F^{\prime}$ ), test holes drilled in Yellow Creek valley penetrated as much as 80 feet of dark gray to blue, dense organic clay.

Alluvium is composed of materials that have been transported by turbulent water currents and deposited when the current velocity decreased. Alluvial deposits are typical in most river valleys. They are found at some sites in the valleys of Roan, Parachute, Piceance, and Yellow Creeks. In contrast, the thick, dark-colored, organic clay found at the two sites along Piceance and Yellow Creeks is commonly deposited in a lake environment. The extreme difference between stream and lake environments in Piceance and Yellow Creek valleys poses two major questions:

1. How were the clay beds formed in a river valley?

2. What is the effect of the clay beds on ground-water movement in the valley-fill material?

\section{NATURAL DAMS PROBABLY FORMED LAKES ALONG PICEANCE AND YELLOW CREEKS}

During early Holocene time, the flood plains of Piceance and Yellow Creeks probably were at least 60 feet lower than at present. A change in weather pattern may have concentrated and intensified rainfall in the catchment areas of some large tributaries. The resulting increased streamflow carried large quantities of sand and gravel down to the flood plain of the main stream valley, where the sediment was deposited as a large fan at the mouth of each tributary. Progressively the fan extended across the main stream valley, and ultimately the fan deposits became a dam, impounding streamflow and creating a lake, which may have extended more than a mile upstream. The coarse sediment-sand and gravel-was deposited where the main stream entered the lake. The fine sediment-silt and clay - was carried into the lake where it slowly accumulated to form a large clay plug that thins upstream from the dam. 


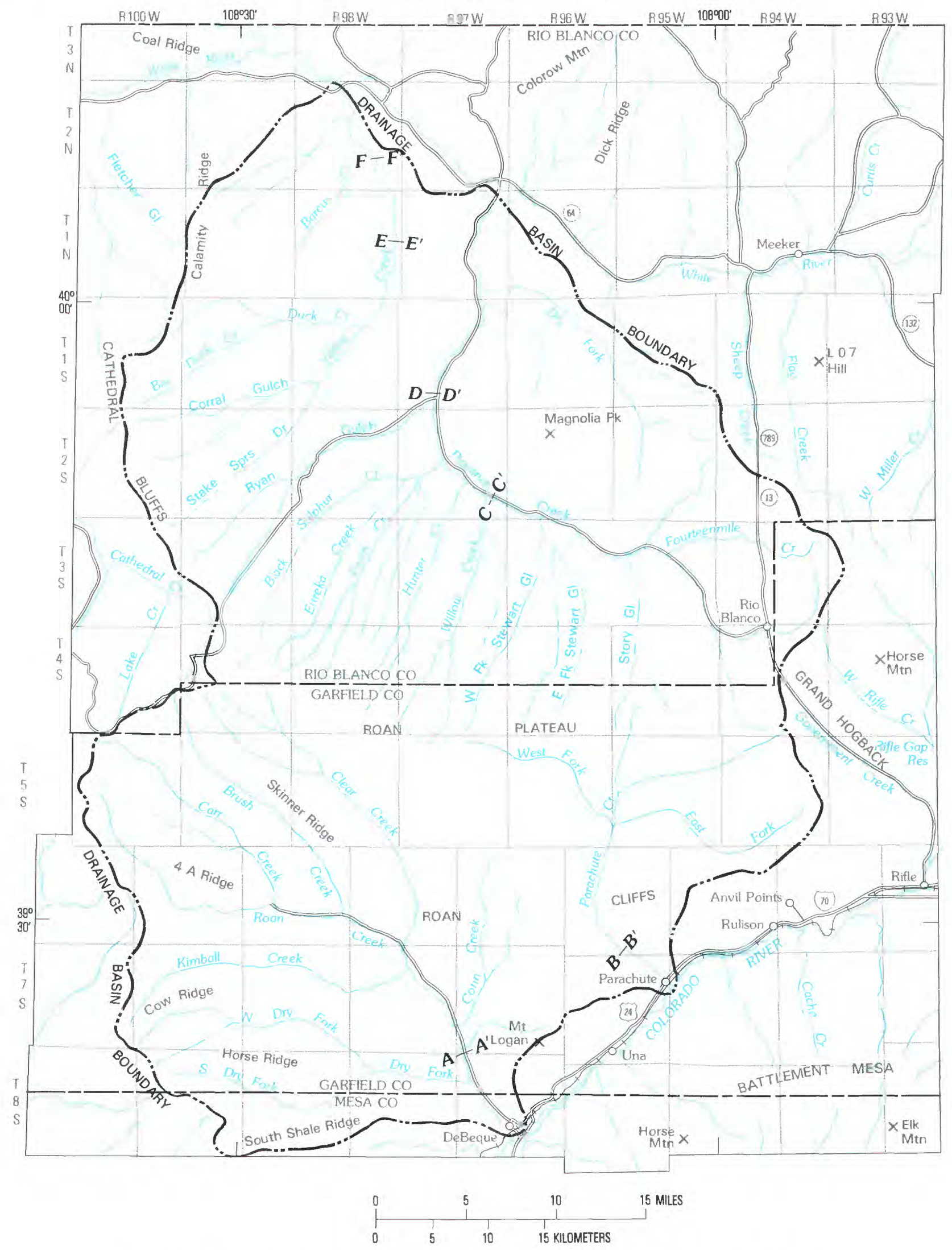

Locations of cross sections where the valley-fill alluvium was explored by drilling (fig. 35 ). 


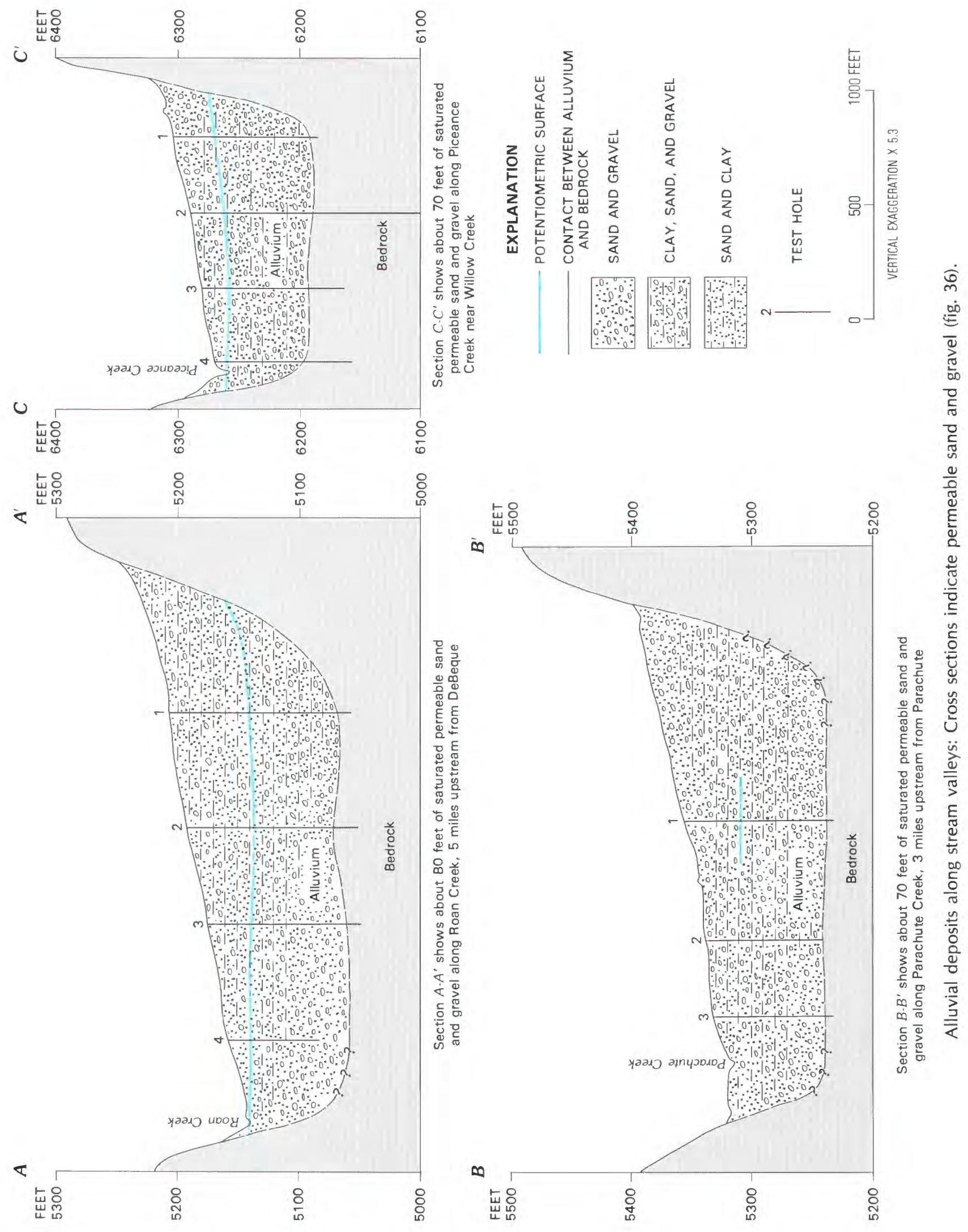



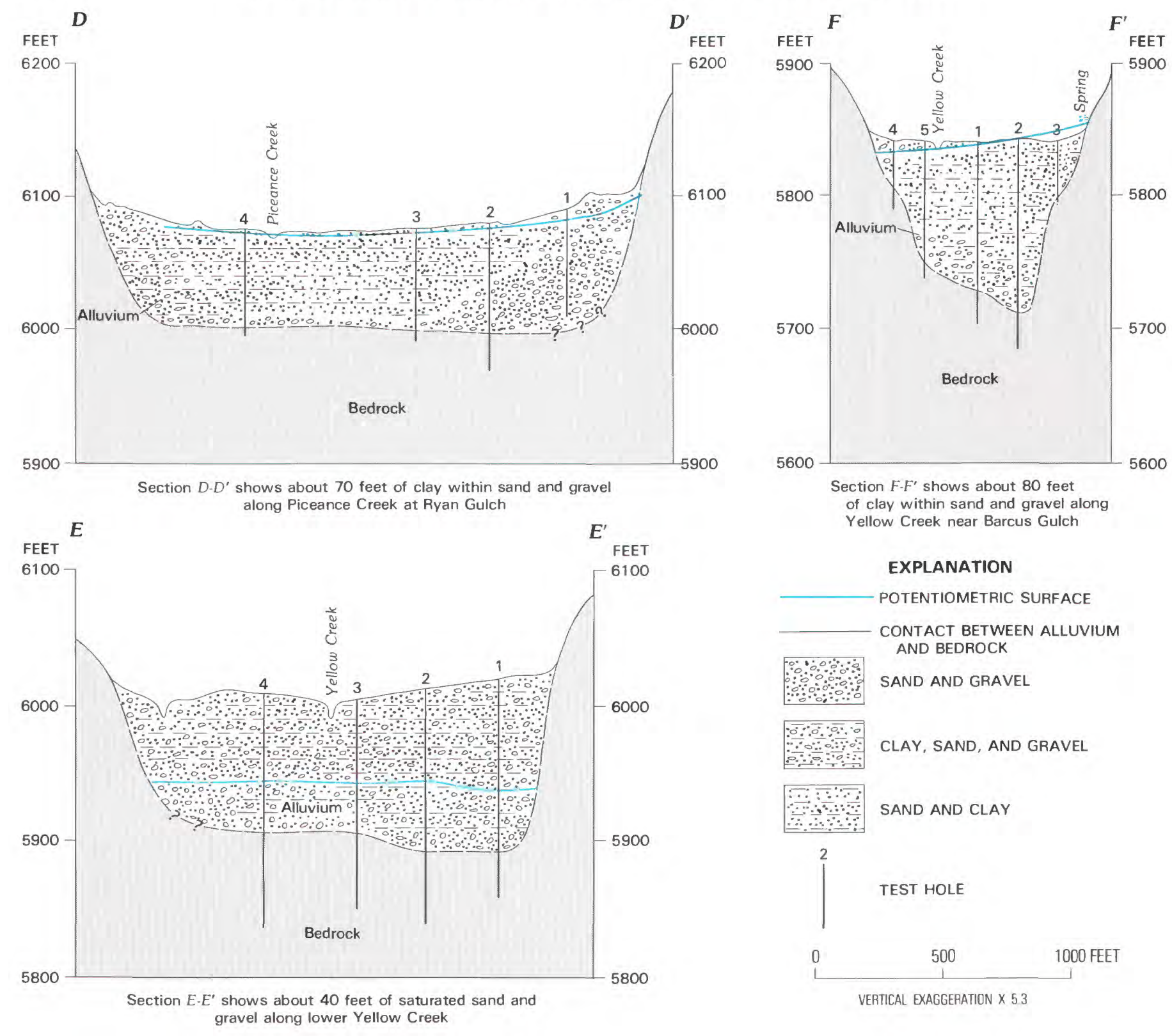

EXPLANATION

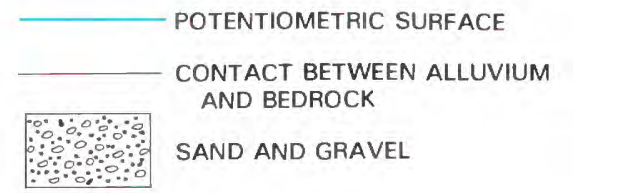

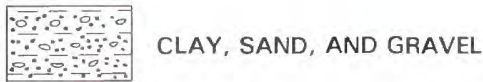
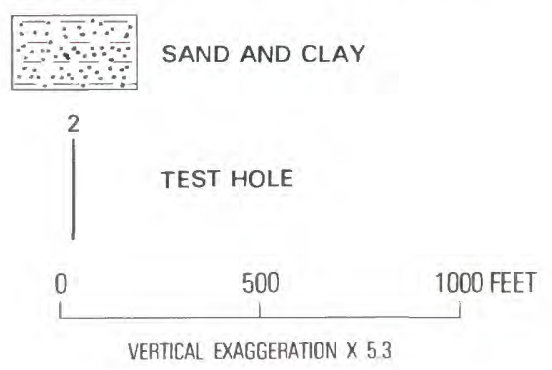

Lake and alluvial deposits along stream valleys: Sections $D-D^{\prime}$ and $F-F^{\prime}$ indicate tight clay lake deposits associated with permeable sand and gravel alluvial deposits. Clay was not detected in section $E-E^{\prime}$ (fig. 37).

\section{GROUND WATER AND SURFACE WATER ARE INTERRELATED}

The stream-deposited sand and gravel and lake-deposited clay have different permeabilities that affect water movement through the valley-fill alluvial aquifer and also affect streamflow. Water in the aquifer moves in the downstream direction. Where the aquifer consists of permeable sand and gravel, the water movement is relatively rapid, and the water table may be 10 feet or more below the land surface. In these valley reaches, the water in the alluvium does not discharge to the streams, which thus go dry during periods of low precipitation. Where the water moving down the valley encounters the relatively impermeable clay of a former lake, the rate of water movement in the aquifer is reduced, and most of the water moves upward toward the land surface between the clay plug and the bedrock. The water forced upward discharges as springs, which maintain streamflow throughout the year. The type of material in the alluvial deposits determines whether the water moves downstream as ground water in the alluvium or as surface water in the stream channel. 

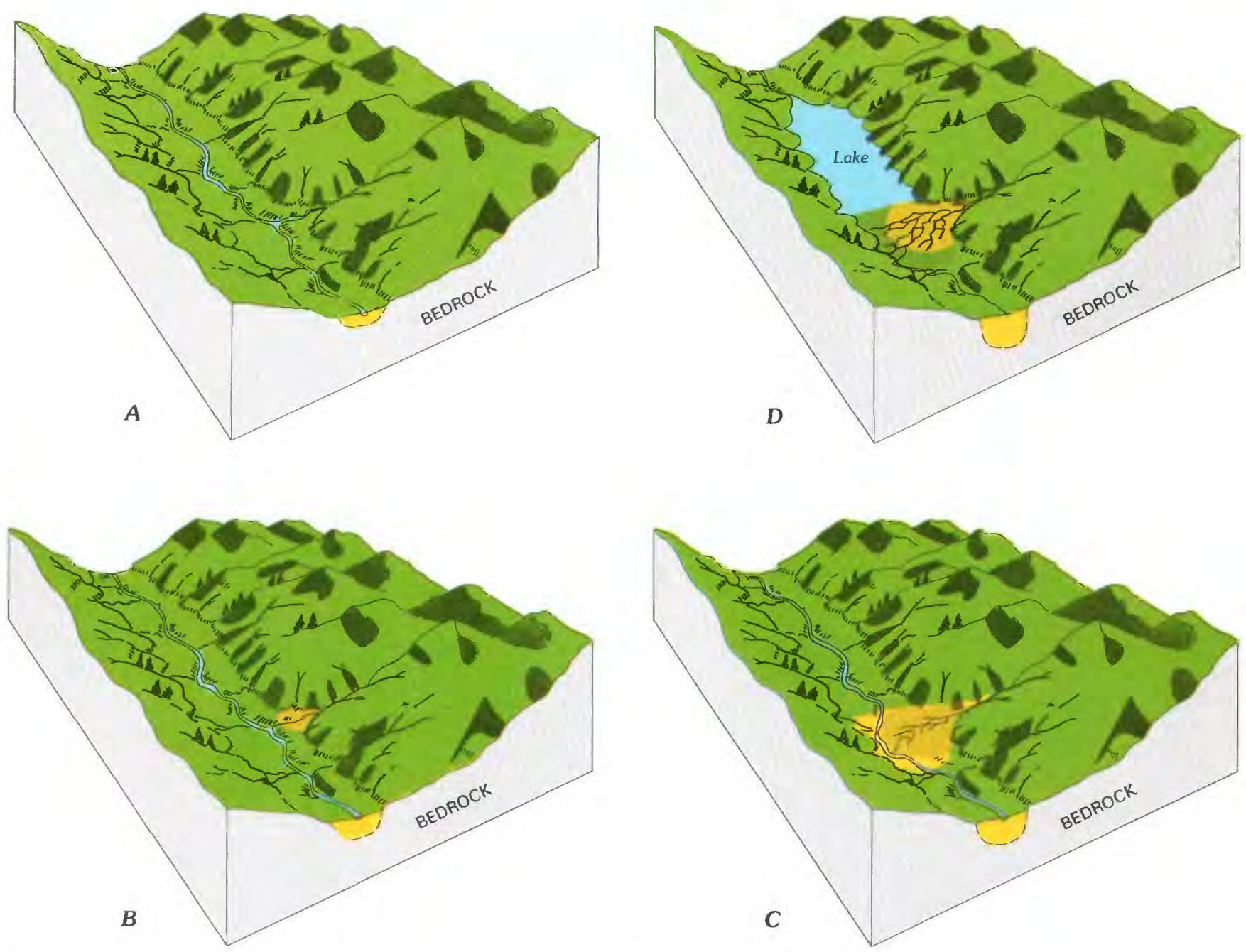

Lake formation in Piceance basin. A, Initially a stream and tributary flowed over valleyfill alluvium. B, Increased flow in the tributary transported large quantities of sediment into the main stream valley. This sediment was deposited as an alluvial fan at the mouth of the tributary. C, As the alluvial fan enlarged, it displaced the stream in the main valley. D, Eventually the fan dammed the stream, caused the formation of a lake, and allowed fine sediment to accumulate in the lake (fig. 38).

The bedrock aquifers of the Uinta and Green River Formations discharge in the valleys of Piceance and Yellow Creeks. Some investigators believe that most of the springs in the Piceance basin are supplied directly by water discharging from the bedrock aquifers through fractures. If this is so, drainage of the bedrock in the process of mining oil shale would dry up the springs and rapidly decrease streamflow. However, based on geologic studies of the extensive clay deposits in some reaches of the valleys of Piceance and Yellow Creeks, the connection between the bedrock aquifers and the valley-fill alluvial aquifers is limited. Therefore, in some regions of the basin, the drainage of mines in the bedrock will affect the streamflow and water in the alluvium less rapidly, because the clay will retard the movement of the water. The hydrology of the bedrock aquifers is discussed in greater detail in the following chapter "Hydrologic system of Piceance basin."

\section{REFERENCES}

Bass, N. W., and Northrop, S. A., 1963, Geology of Glenwood Springs quadrangle and vicinity, northwestern Colorado: U.S. Geological Survey Bulletin 1142-J, 74 p.

Coffin, D. L., Welder, F. A., Glanzman, R. K., and Dutton, X. W., 1968, Geohydrologic data from Piceance Creek basin between the White and Colorado Rivers, northwestern Colorado: U.S. Geological Survey Circular $12,38 \mathrm{p}$.

Lohman, S. W., 1965, Geology and artesian water supply, Grand Junction area, Colorado: U.S. Geological Survey Professional Paper 451, 149 p.

The streams and ground water in the Piceance basin are part of the Colorado River basin in which water shortages are common. Mineral development will disrupt the local flow systems and consume part of the available water supplies. A description of the characteristics of the flow system and Colorado water law follows. 


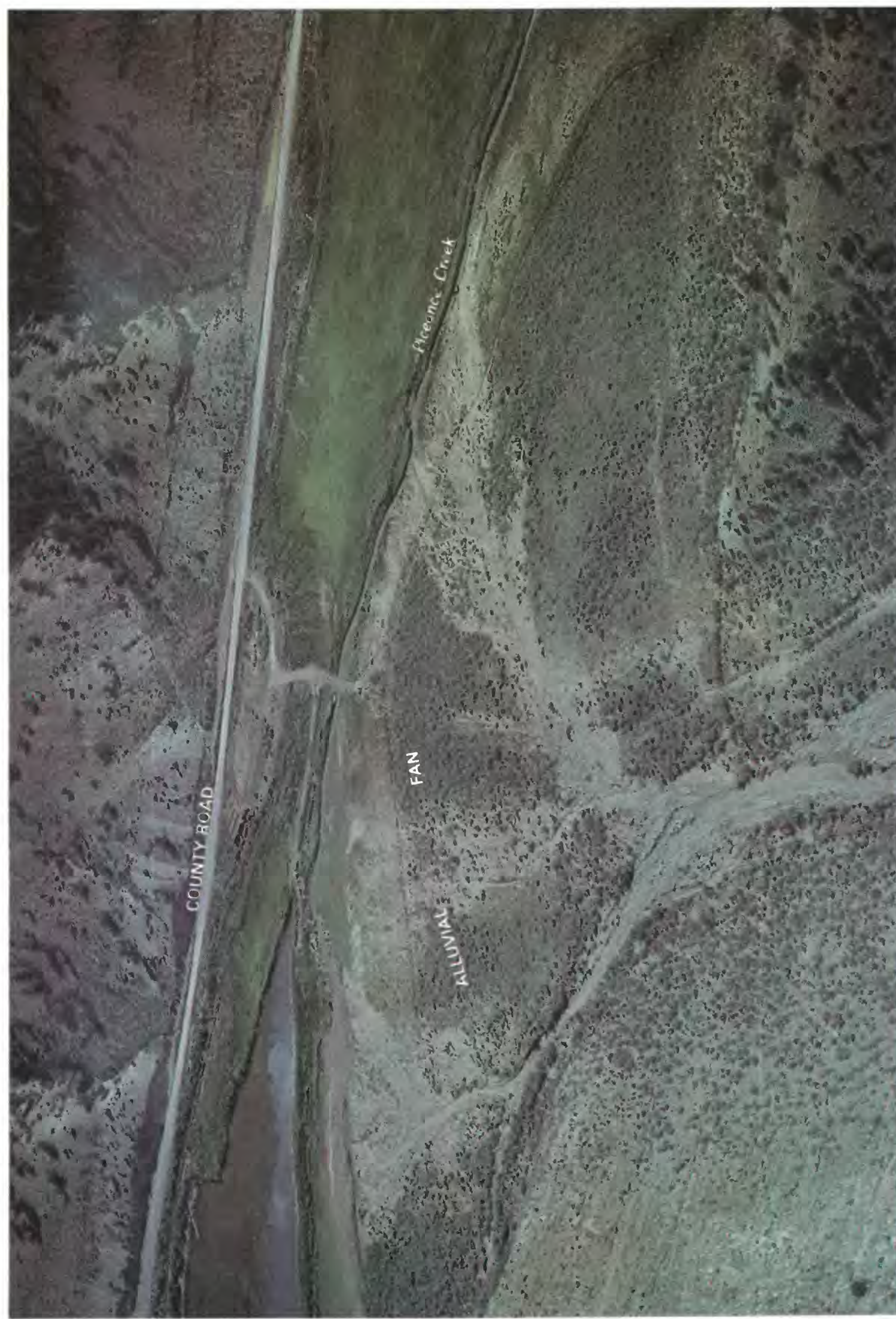

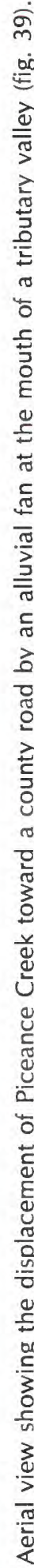




\title{
HYDROLOGIC SYSTEM OF PICEANCE BASIN
}

\author{
BY O. JAMES TAYLOR
}

Oil-shale development cannot proceed in many parts of the Piceance basin without mine drainage. It also will require water supplies for various industrial activities, which are discussed in the chapter "Development of the oil shale and associated minerals." Furthermore, the changes in the flow systems in the Piceance basin will affect water supplies in other parts of the Colorado River basin. Therefore, an understanding of the hydrologic system in the Piceance basin is important.

\section{THE PICEANCE BASIN IS PART OF THE COLORADO RIVER BASIN}

The Colorado River basin is divided into an upper and a lower basin in order to allocate water supplies, as specified in the Colorado River Compact of 1922. The Piceance basin lies near the center of the Upper Colorado River Basin, a drainage basin of about 113,500 square miles, which includes parts of Arizona, Colorado, New Mexico, Utah, and Wyoming.

This upper basin has an arid to semiarid climate with a normal annual precipitation of only about 16 inches. Precipitation, in the form of rainfall and snow, is the source of the water that replenishes streamflow and recharges the ground-water reservoirs. Evapotranspiration consumes a large part of the precipitation before it can contribute to surface- and ground-water supplies. Therefore, the relatively small average precipitation results in small water supplies, especially in relation to the large water demands in the Colorado River basin, and therefore water shortages are common.

The large and diverse water demands in the upper basin will probably continue to increase. During 1982, the most water was used for irrigation; other uses included export to other basins, powerplant cooling, mineral development, municipal supply, other industrial use, support of fish and wildlife, and recreation. Increased demands are expected for all of these uses, as well as for development of oil shale, tar sand, and coal. Available water will not be sufficient for major oil-shale development during years of average precipitation unless supplies are increased, storage facilities are constructed, and use of water for other purposes is decreased or eliminated.

\section{PRECIPITATION REPLENISHES THE STREAMS}

Normal annual precipitation in the Piceance basin ranges from about 12 to 20 inches. In general, the larger volumes fall at higher altitudes, where more than one-half of the precipitation accumulates as snow. The snowpack normally persists through the winter until the spring thaw. At lower altitudes, the precipitation is approximately one-half rainfall and one-half snowfall, and the snowpack usually melts during the winter. The air temperature at the lower altitudes is warmer than that at the higher altitudes.

Most precipitation is lost to evapotranspiration; an estimated 98 percent of the snowmelt and precipitation is evapotranspired. The remaining water runs off rapidly and replenishes streamflow or recharges the aquifers. The natural recharge replenishes the ground water that moves slowly toward sites of natural discharge along the streams. During periods of intense rainfall or snowmelt, most of the streamflow is derived from surface runoff. During dry periods, most of the streamflow is derived from ground water discharging into the streams.

The Piceance basin includes four major drainage basins. Piceance and Yellow Creeks drain the northern part of the Piceance basin and discharge into the White River. Roan and Parachute Creeks drain the southern part of the Piceance basin and discharge into the Colorado River.

Hydrologists measure streamflow periodically or continuously at selected monitoring sites. Measurements taken over a period of many years are used to calculate statistics that describe the low-flow, mean-flow, and flood-flow characteristics at each site. The mean annual discharge at the mouth of each creek is tabulated below; the total indicates the volume of annual flow.

\begin{tabular}{|c|c|}
\hline \multicolumn{2}{|c|}{ Mean annual discharge in acre-feet } \\
\hline Piceance Creek . & 17,320 \\
\hline Yellow Creek. & 1,240 \\
\hline Roan Creek & 32,140 \\
\hline Parachute Creek & 21,810 \\
\hline Total & 72,510 \\
\hline
\end{tabular}

The different mean annual discharges for the four drainage basins are due to the different amounts of mean annual precipitation, snowpack thickness, type and amount of vegetation cover, and drainage area for each basin. 


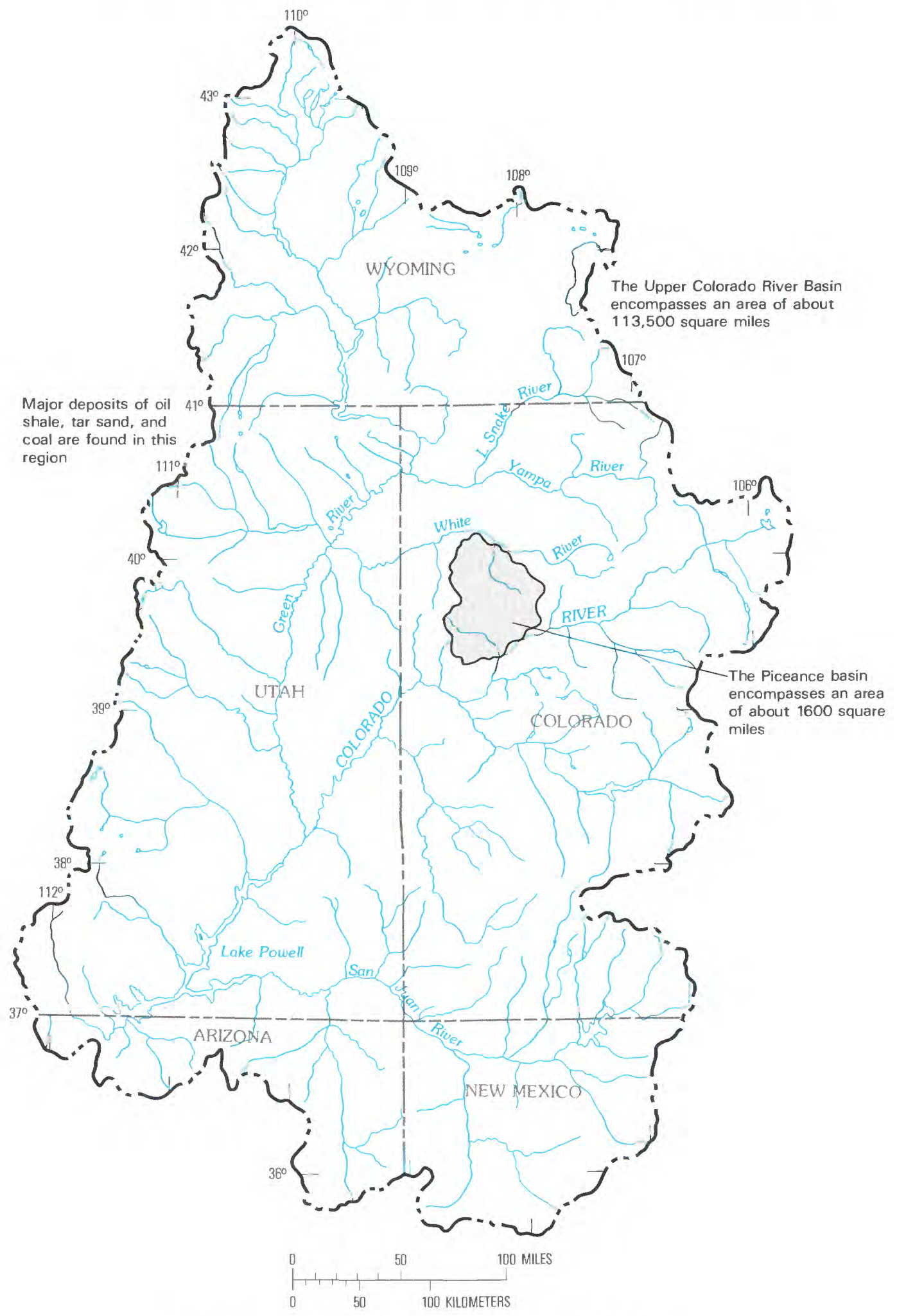

Changes in the water resources of the Upper Colorado River Basin also may affect the lower basin States of Arizona, California,

Nevada, New Mexico, and Utah; Mexico; and regions that export water from the upper basin

The Upper Colorado River Basin (fig. 40). 


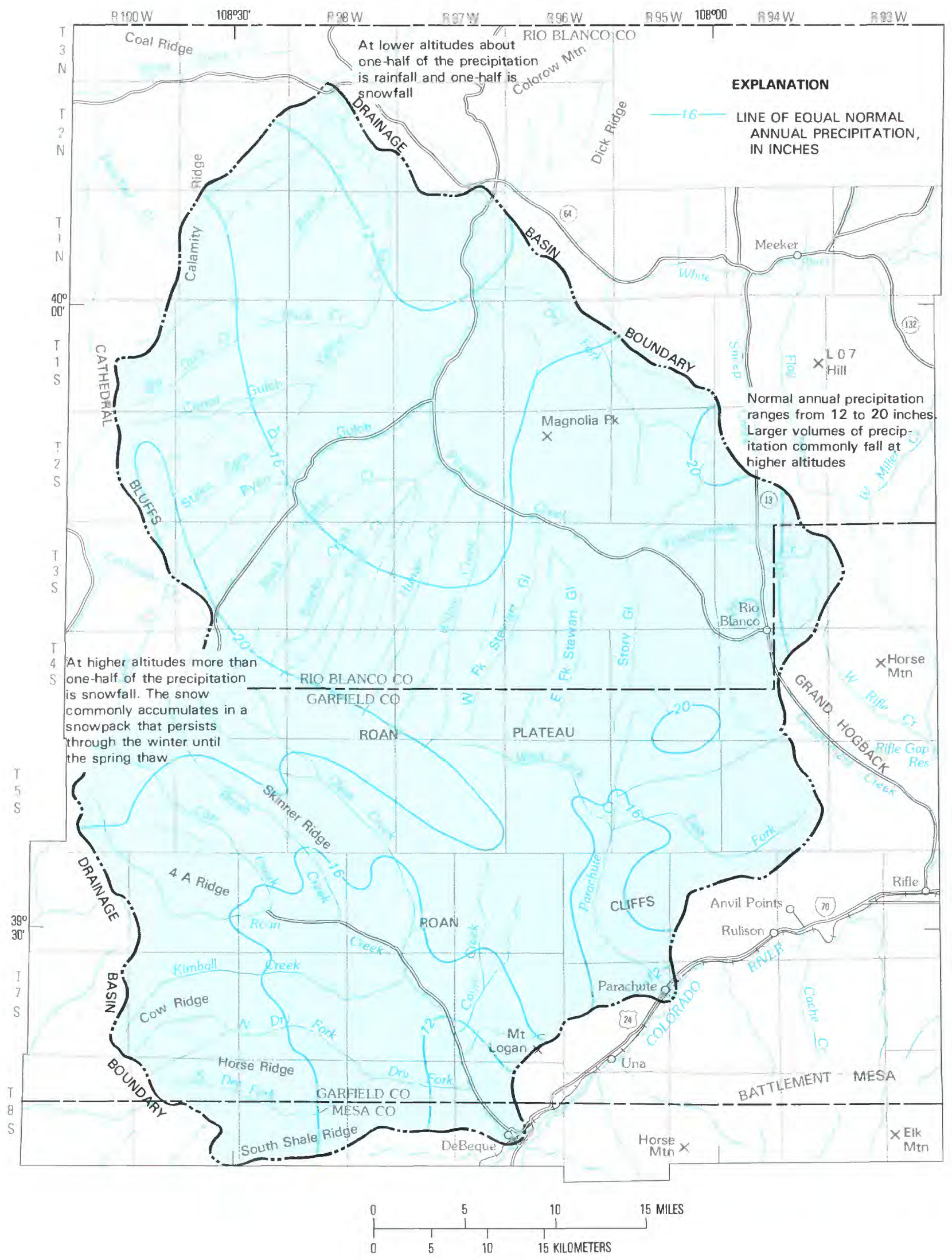

Normal annual precipitation in Piceance basin 1931-60 (fig. 41). 


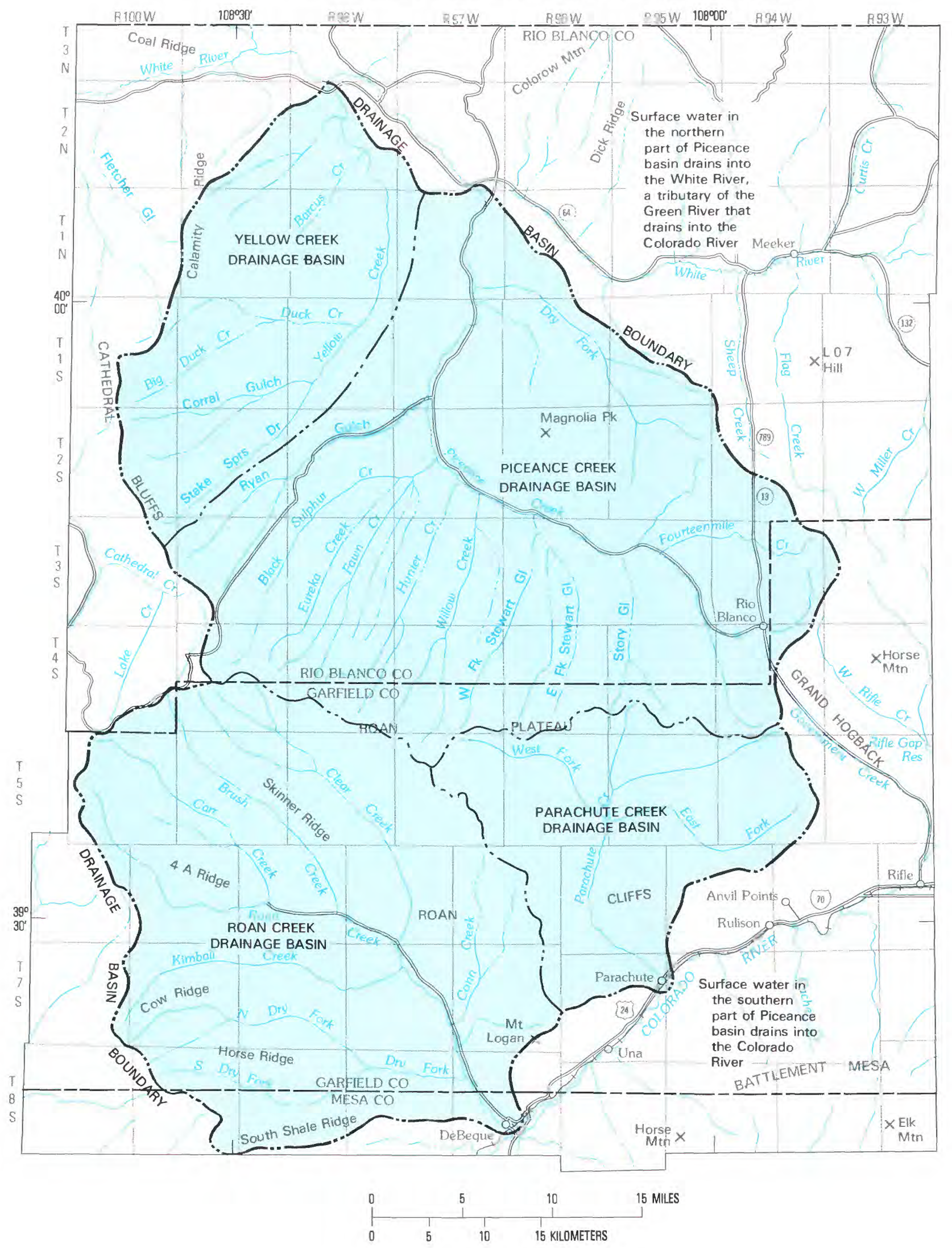

Major drainage basins of the Piceance basin (fig. 42). 


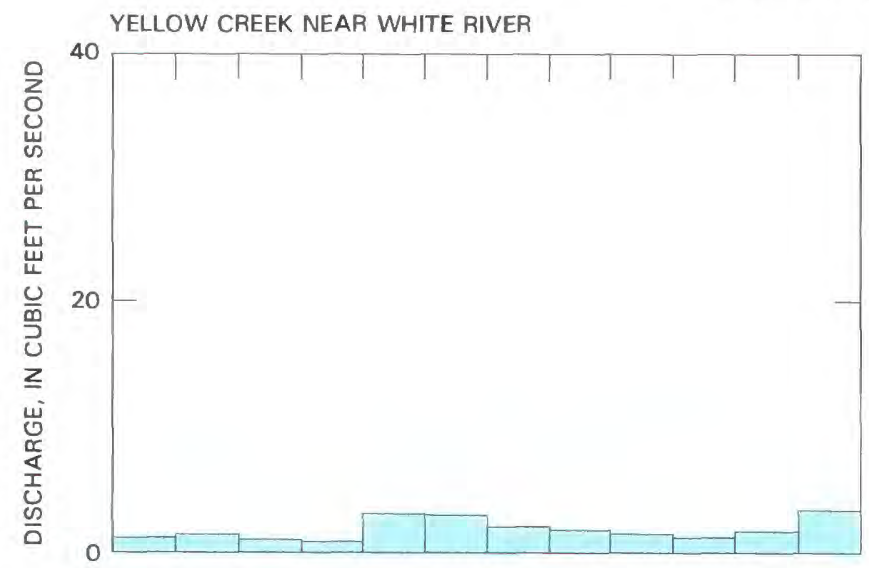

PICEANCE CREEK AT WHITE RIVER
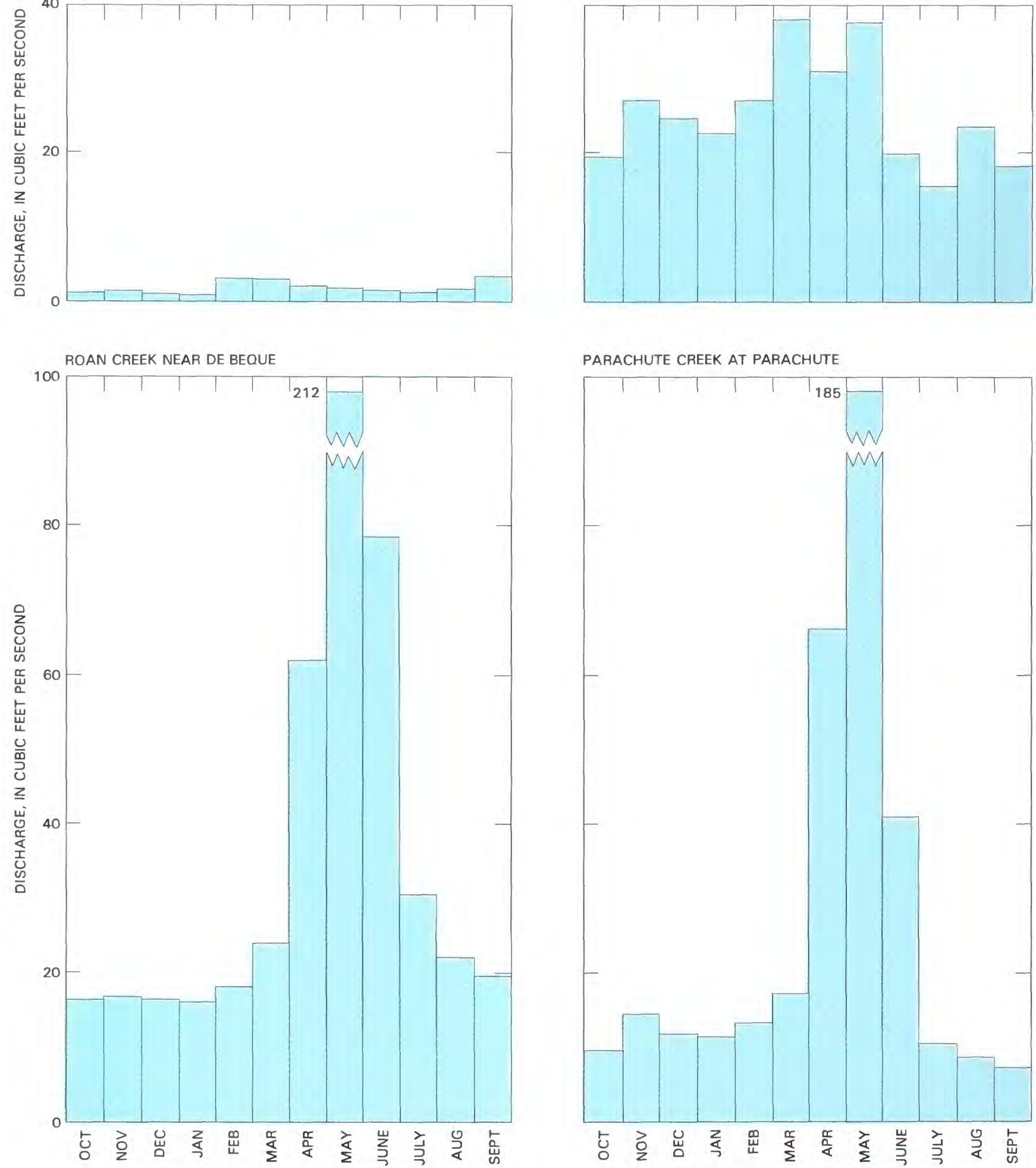

PARACHUTE CREEK AT PARACHUTE

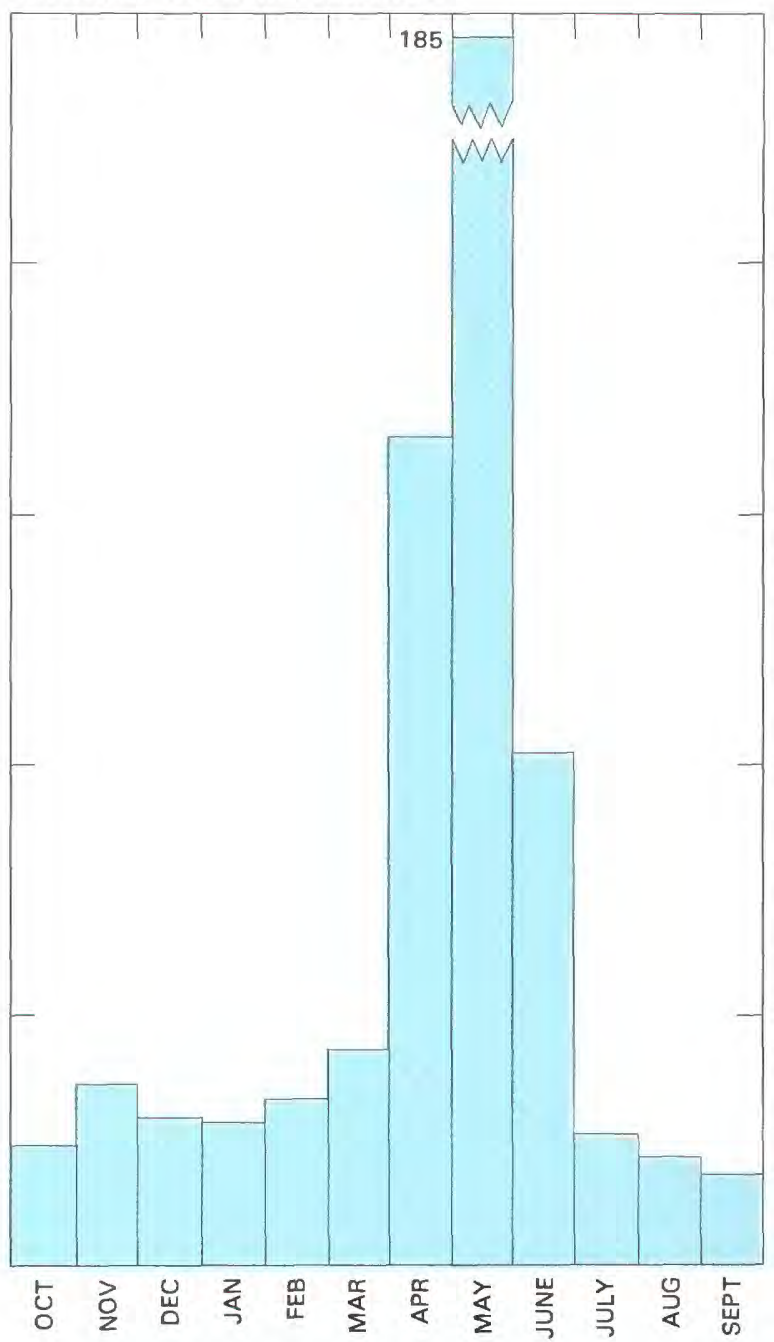

Mean monthly discharge near the mouths of major streams (fig. 43). 
The tabulated values of mean annual discharge of the creeks do not indicate the large annual and seasonal variations in flow. Peak stream discharges usually occur during the spring following snowmelt and during the summer following intense rainfall. Low-flow conditions are common during late fall and winter, when streamflow is mostly supplied by discharge from the ground-water reservoirs to the stream valleys. Irrigation practices along the flood plains also affect the magnitude of streamflow.

Stream water moves faster at high-flow than at low-flow conditions. During peak flows, water probably moves from the headwaters to the mouth of Piceance Creek in about a day; during low flows, however, the travel time can be several days. Ground water moves much more slowly than surface water.

\section{A WATERSHED MODEL IS USED TO STUDY THE SURFACE-WATER SYSTEM}

Water-resource systems are so complex that an accurate understanding of their behavior requires numerous field measurements that can be used in the solution of many complex equations. The required calculations are so tedious that models are often prepared. The surface-water system in parts of the Piceance basin has been studied using a watershed model. This model simulates the principal components of the surface-water system including precipitation, snowmelt, sublimation, evapotranspiration, overland flow, infiltration, and natural recharge. In order to use the watershed model, the hydrologist subdivides a map of a watershed into hydrologic-response units-areas that are considered homogeneous with respect to the land slope, the compass direction that the slope faces, the type of vegetation, the type of soil, and the distribution of the snowpack.

The model is operated by coupling data describing the physical and hydrologic characteristics of each hydrologicresponse unit with the appropriate physical and hydrologic flow equations which are solved using a computer. The watershed model also calculates the cumulative hydrologic effects of each hydrologic-response unit, in order to predict the total streamflow from the watershed.

The watershed model needs to be calibrated to insure reasonable accuracy. Model calibration is effected by adjusting the data describing the physical and hydrologic parameters and possibly the flow equations until simulated streamflow approximates actual streamflow. A model is said to be calibrated if it accurately simulates the observed streamflow. However, the model may fail to simulate streamflow under extreme conditions that were not used in model calibration, and then the calibration process must be repeated.

\section{CALIBRATED WATERSHED MODELS HAVE BEEN USED TO STUDY THE SURFACE-WATER SYSTEM OF THE PICEANCE BASIN}

Watershed models prepared for the northern part of the Piceance basin have improved the understanding of the surface-water system of the basin. Simulation of the natural flow system indicates that natural recharge to bedrock aquifers is greatest in areas of high land-surface altitude, presumably because the thick snowpack and the slow melting process allow infiltration.

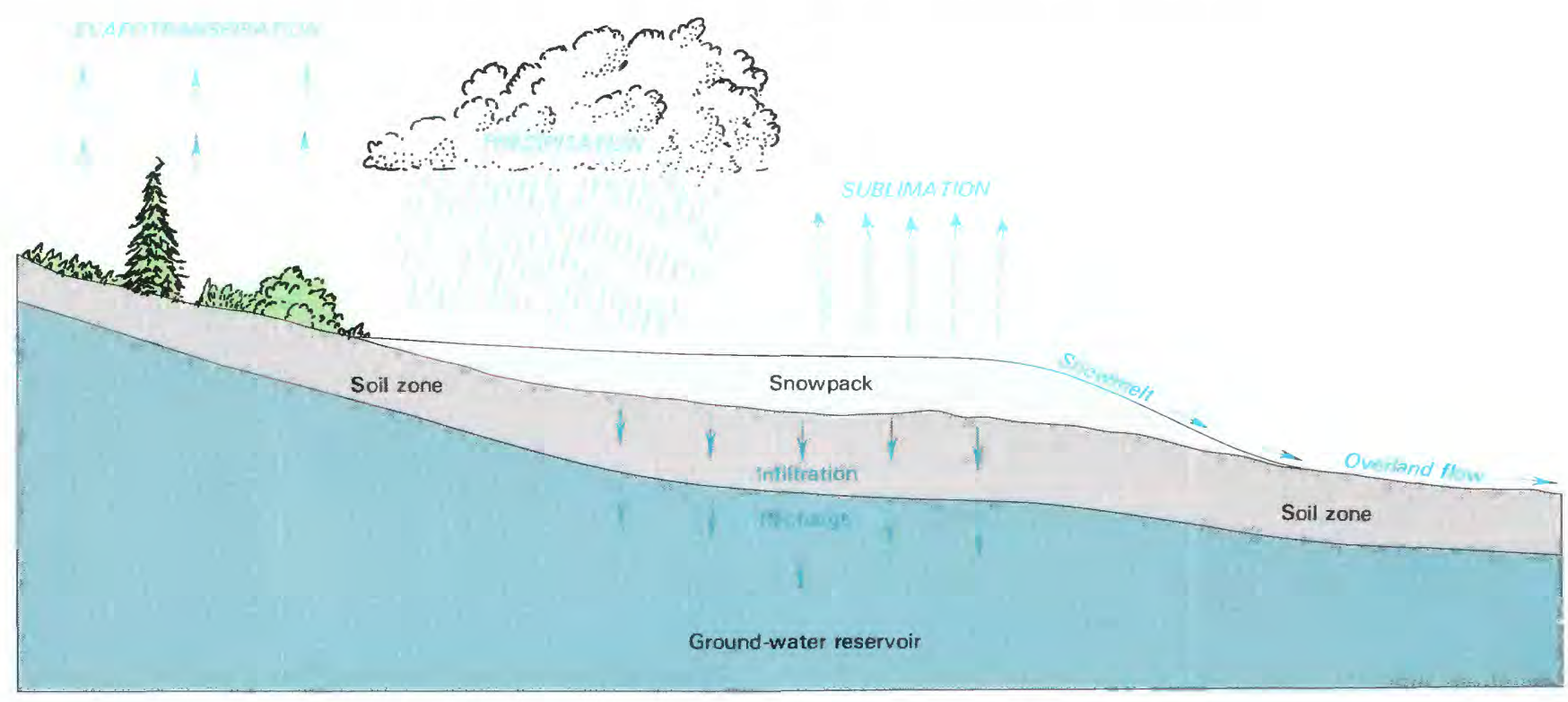

Hydrologic flow components simulated in watershed model (fig. 44). 


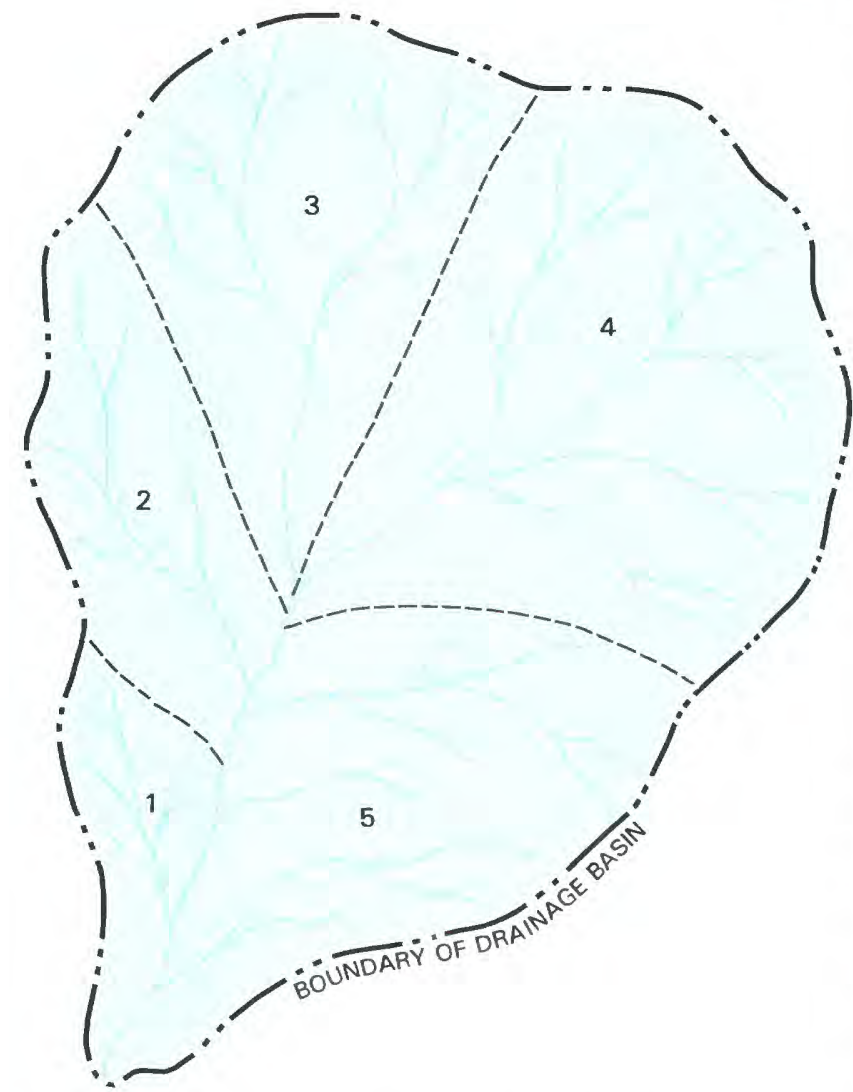

Map of drainage basin subdivided into hydrologic response units for watershed modeling (fig. 45).

Simulation of the surface-water system for various levels of hypothetical oil-shale development indicates that the development of a large oil-shale industry may increase surface runoff. Spoil piles emplaced in areas of natural recharge may reduce or eliminate recharge. A reduction in natural recharge may correspondingly increase surface runoff.

Watershed models cannot answer all questions or solve all problems related to surface-water hydrology. They are simplified representations of complex systems. They can help us to understand which factors have the most effect on the system and possibly to predict the hydrologic effects of various courses of action, land-use decisions, and levels of development.

\section{THE GEOLOGIC FORMATIONS ASSOCIATED WITH OIL SHALE INCLUDE GROUND-WATER RESERVOIRS}

Geologic formations are an important part of the hydrologic system of Piceance basin because all or parts of some of them are aquifers. The aquifers transmit and store water and form a major part of the overall flow system. The aquifers associated with the oil shale in the basin are several permeable zones within the Green River Formation and the Uinta Formation. The zones are permeable because they have fractures and interconnected pores. Geologic beds that are less permeable than the aquifer zones tend to retard groundwater movement, but do not stop it. Fractures are discussed in detail in the chapter "Systematic joints within oil shales and associated rocks of the Green River Formation."

The Garden Gulch Member of the Green River Formation is comprised of marlstone and sandstone that are not permeable. This member and stratigraphically equivalent beds in the southern part of the basin form a lower boundary for the overlying aquifers that are associated with the oil shale.

The aquifer zones within the lower Parachute Creek Member of the Green River Formation overlie the Garden Gulch Member. These aquifers were formed when the brittle oil shale was fractured and part of the soluble minerals were dissolved by circulating ground water. Locally, these aquifers are called the lower aquifers. In the northern part of the Piceance basin, an unfractured zone called the HR (high resistivity) zone lies just above the Garden Gulch Member. This zone was named for its high electrical resistance, as determined using geophysical logs. The HR zone is not permeable and, therefore, forms a boundary beneath the lower aquifers that stratigraphically overlie the Garden Gulch Member. Above the HR zone in the northern part of the basin is the leached zone. The solution of the minerals nahcolite, dawsonite, and halite formed many channels and resulted in a permeable zone within the upper part of the lower aquifers. The lower aquifers average about 900 feet in thickness.

A confining layer known as the Mahogany zone of the Parachute Creek Member of the Green River Formation lies above the lower aquifer. This zone consists of rich oil shale with few fractures. The Mahogany zone confines the aquifers below it because its low permeability retards but does not stop water movement. The average thickness of the Mahogany zone is about 160 feet.

Stratigraphically above the Mahogany zone is a series of bedrock aquifers within the upper part of the Parachute Creek Member of the Green River Formation and the Uinta Formation. These aquifers consist of permeable sandstone and fractured siltstone of the Uinta Formation and fractured marlstone and solution cavities in the Green River Formation. Locally these aquifers are known as the upper aquifers. Their average thickness is about 700 feet.

The geology of the formations of Tertiary age that include these aquifers is discussed in the chapter "General geology of the Piceance basin."

Permeability of the upper and lower aquifers resulted from the structural deformation of geologic formations and the solution of minerals. Originally the formations consisted of fine, cemented particles of sedimentary rock. The sandstones 


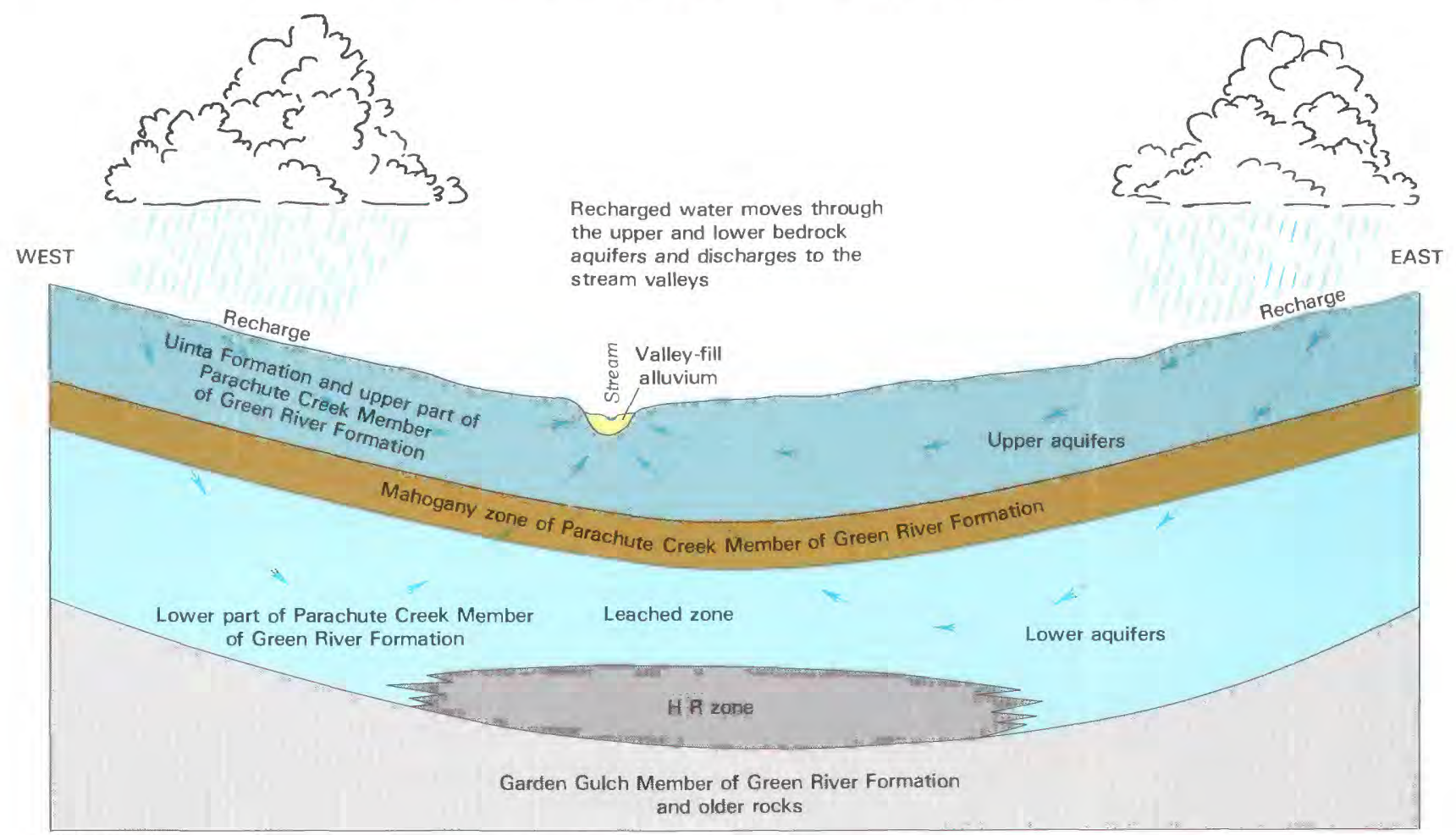

A. PICEANCE AND YELLOW CREEK DRAINAGE BASINS
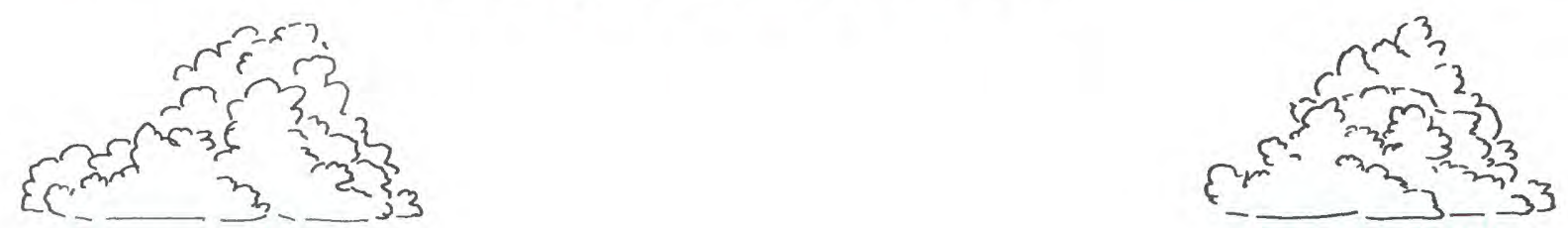

WEST

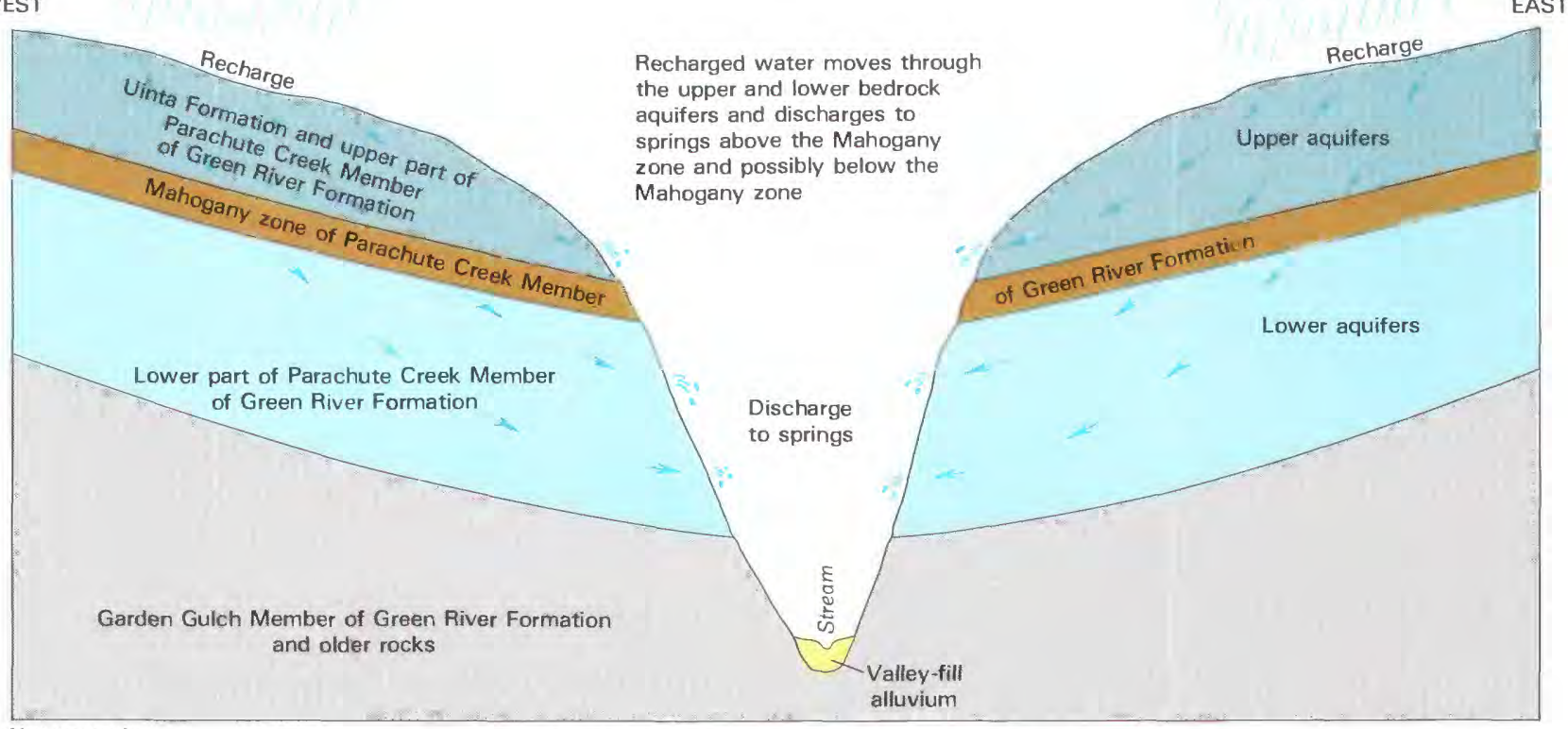

Not to scale

B. ROAN AND PARACHUTE CREEK DRAINAGE BASINS

Diagrammatic east-west sections of hydrologic system (fig. 46). 
and siltstones were permeable because of their interconnected pores; the shales were not sufficiently permeable to be aquifers. However, fracturing of parts of the formations formed pathways that permitted water from snowmelt and rainfall to recharge the formation, and to dissolve and remove some of the minerals. These fractures and solution channels increased the permeability sufficiently so that many parts of the formations are now aquifers. Locally, the flow system is controlled by the fractures and solution channels; regionally, it is controlled by the precipitation pattern and the stream system.

\section{PRECIPITATION RECHARGES THE AQUIFERS THAT STORE WATER AND TRANSMIT WATER TO STREAMS OR SPRINGS}

A ground-water system is a dynamic system that stores and transmits water. The system is maintained by precipitation that infiltrates the ground and recharges the aquifers. Several ground-water models constructed for the Piceance basin indicate that natural recharge is about 36,000 acre-feet per year. The ground water moves slowly toward regions of natural discharge, where it emerges from the aquifers.

The flow path taken by the ground water depends on the energy level throughout the flow system. This energy level is related to the altitude and pressure of the water at each point in the flow system. As the ground water moves, energy is consumed because of frictional losses as the fluid is forced through the fractures and pores in the rocks. Therefore, the ground-water movement is from higher to lower energy levels, which may be in any direction and not necessarily downward.

In the Piceance basin, the principal natural recharge is snowmelt that infiltrates the bedrock aquifers in the higher parts of the basin. The recharge moves slowly laterally and downward through the upper aquifers. The water in the upper aquifers follows the pathways created by the fracture system and the interconnected pores. In general, the water moves about twice as easily horizontally as vertically because the fracture-to-fracture connection is greater horizontally than vertically. Also the horizontal orientation of grains in the porous sandstone and siltstone promotes horizontal movement.

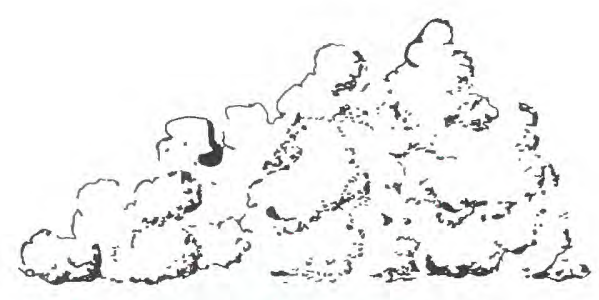

NORTH

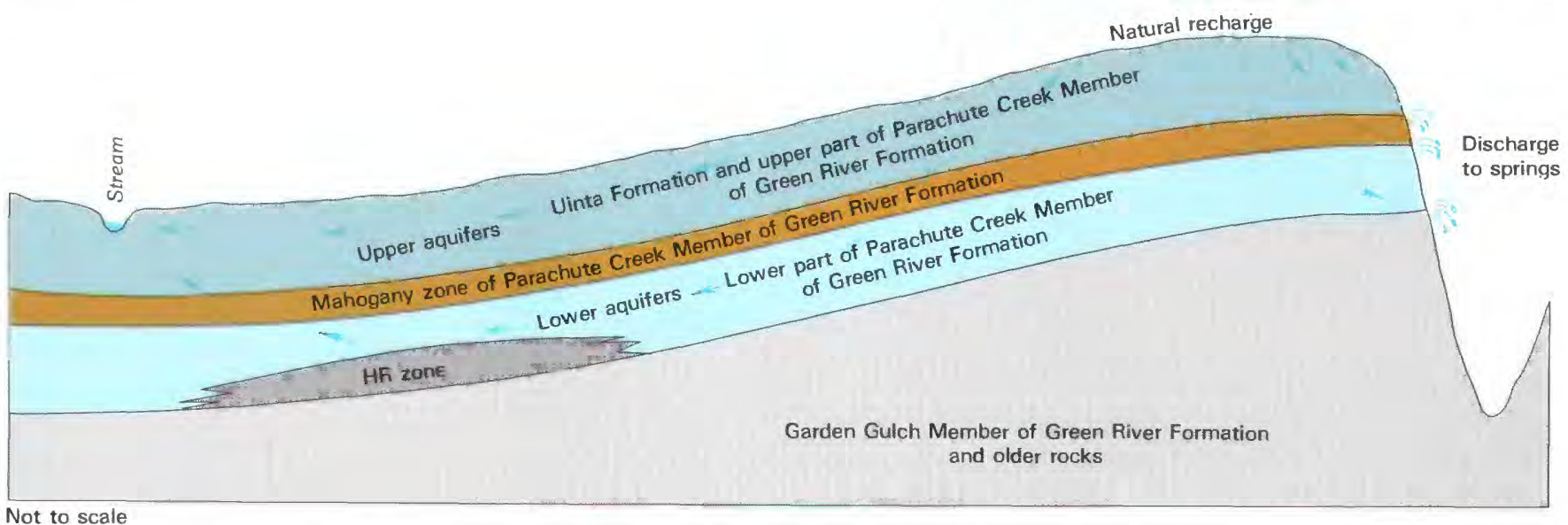

Diagrammatic north-south section of hydrologic system (fig. 47). 
Part of the water moving downward through the upper aquifers eventually reaches the Mahogany zone. This zone is less permeable than the overlying and underlying aquifers because it generally lacks fractures. Although vertical water movement may be negligible through a small area of the Mahogany zone, it may transmit substantial quantities of water over its large areal extent.

Water passing through the Mahogany zone eventually enters the lower aquifers where it moves through fractures and the solution openings. Studies of the lower aquifers indicate that their horizontal permeability is as much as 15 times greater than their vertical permeability because of the patterns of fractures and solution openings. Therefore, water can move more easily horizontally than vertically.

The water in the upper and lower aquifers moves horizontally through the basin to the discharge areas. In the Piceance and Yellow Creeks drainage basin, the water eventually moves upward through the aquifer system where it discharges into the valley-fill alluvial aquifer or emerges as springs in the stream valleys. In these valleys the water discharging from the bedrock mixes with water in the valleyfill alluvium and with water in the stream channel that originated as surface runoff. Measurements of streamflow along Piceance Creek indicate that:

1. Ground water discharging into the stream causes stream gains along many reaches, and

2. Surface water recharging the ground-water reservoirs causes stream losses along other reaches.

The stream gains exceed stream losses, with a net gain of about 15 cubic feet per second for the Piceance Creek on March 26, 1981. The indicated gains and losses will be understood more clearly when the measurements have been repeated at different times of the year, and the persistence of the gains and losses is determined.

In the Roan and Parachute Creek drainage basins, water moves horizontally through the aquifers to springs that discharge hundreds of feet above the streams in the deep canyons. Some of the discharged water evaporates, some is used by plants, and the rest flows down the steep bedrock slopes to the streams below.

Ground water moves very slowly in comparison to surface water. The maximum transit time for water movement from the recharge areas through the aquifer system to areas of discharge is probably many hundreds of years.

The total volume of ground water stored in the Piceance basin is not known, because the average porosity of fractures, pores, and solution cavities is not completely understood. The total volume of the upper and lower aquifers is approximately 480 cubic miles, and estimates of the stored ground water can be expressed in terms of estimated average porosities that range from 0.5 to 5 percent. The following table shows the volume of ground water stored in the Piceance basin corresponding to estimated average porosity of fractures, pores, and solution cavities.

\begin{tabular}{cc}
\hline $\begin{array}{c}\text { Estimated average } \\
\text { porosity of } \\
\text { fractures, pores, } \\
\text { and solution } \\
\text { cavities } \\
\text { (percent) }\end{array}$ & $\begin{array}{c}\text { Volume of } \\
\text { ground water } \\
\text { stored in } \\
\text { Piceance basin } \\
\text { (millions of } \\
\text { acre-feet) }\end{array}$ \\
\hline 0.5 & 8 \\
1 & 16 \\
2 & 33 \\
3 & 49 \\
4 & 65 \\
5 & 81 \\
\hline
\end{tabular}

\section{GROUND-WATER MODELS ARE USED TO STUDY THE FLOW SYSTEM OF THE AQUIFERS AND THE CONFINING LAYER}

The subsurface flow system of Piceance basin has been studied using ground-water models because of the complexity of the flow system. These models are capable of simulating the integrated effects of recharge, movement, and discharge of water, as well as changes in stored water. Several models have been developed for parts of the Piceance basin. One current model, developed by the U.S. Geological Survey, simulates the aquifers, confining layer, major streams, and springs in the entire basin.

To use the ground-water model, the hydrologist subdivides maps of the flow system into layers and nodes. Data describing the aquifer characteristics within each node can be specified to account for different characteristics in various parts of the basin. The characteristics of permeability and storage due to the directional fractures and solution cavities are described for the aquifer nodes as accurately as possible. Certain other nodes in the model are used to simulate streams and springs, and these nodes are distinguished from nodes that represent aquifers. The model is operated by coupling the data describing the physical and hydrologic characteristics of each node with the appropriate physical and hydrologic flow equations. Computers are used to solve the flow equations.

After model calibration is complete, the model will be useful for assessing management alternatives. For example, the effects of pumping can be simulated at various nodes for various time periods, and the resulting impact on streams, springs, and stored ground water can be predicted using the model. The current model for the Piceance basin is not completely calibrated because onsite data are insufficient to assign accurate permeability and storage values to all model nodes. Additional permeability and storage values are being compiled by aquifer testing, a field technique in which water is pumped from or injected into the aquifer. The response of the aquifer is used to derive the needed values. Eventually, the model will be used to make quantitative predictions concerning the hydrologic effects of future mine drainage. 


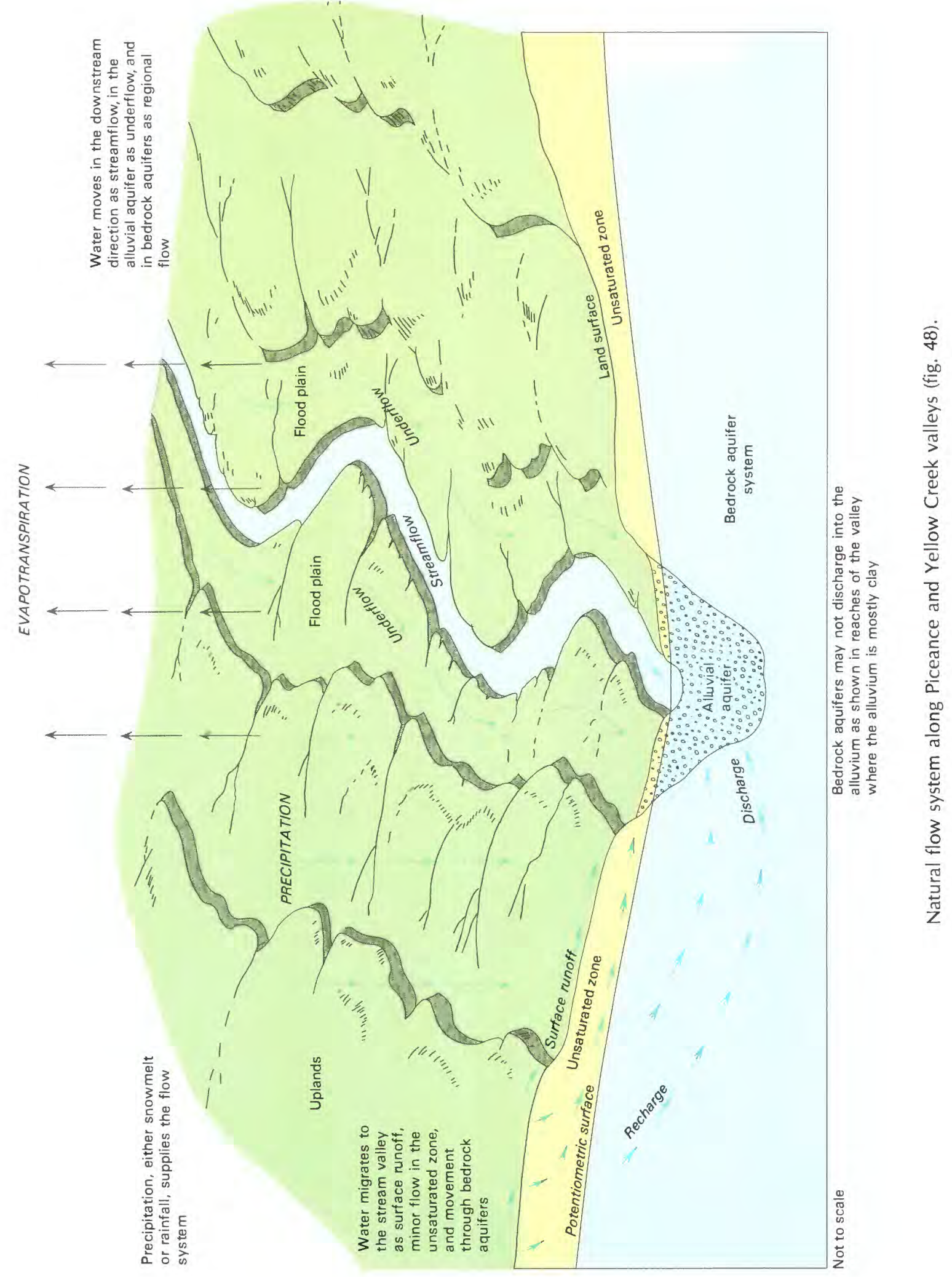


THE DOCTRINE OF PRIOR APPROPRIATION IS USED TO ALLOCATE SURFACE WATER, SPRING WATER, GROUND WATER, AND RESERVOIR WATER IN COLORADO

\section{SURFACE WATER}

The Constitution of the State of Colorado provides, in Article XVI, "The water of every natural stream, not heretofore appropriated, within the State of Colorado, is hereby declared to be the property of the public." In Colorado, an appropriation may be initiated by diverting the water and consummated by applying the water to a beneficial use. However, an appropriation by itself is not a water right. A valid water right requires that the appropriation be adjudicated in the water court of that water division. There are seven water divisions in Colorado which correspond approximately to the major drainage basins in the State.

Because water is in short supply in Colorado, a method for determining the priority of water rights was established. This method is the Doctrine of Prior Appropriation. Under the Doctrine, early water rights have priority for diversion and use of water, compared to water rights established at a later date. The State Engineer is responsible for administering the water rights in Colorado. The holder of a senior water right has the prerogative to satisfy the full amount of his decreed water right before any junior water rights are allowed to divert and use the water.

A water right does not guarantee, however, that the water is available for diversion. In times of average precipitation and streamflow, only the holders of senior water rights may have the opportunity to divert all or part of their appropriation. Conversely, the holders of junior water rights may have the opportunity to divert their appropriation only rarely, when precipitation and streamflow are extremely high.

\section{SPRINGS}

Water discharging from a spring normally can be allocated in a manner similar to that for surface water. After diverting the spring water and applying the water to a beneficial use, the appropriation can be adjudicated to obtain a water right. In the Piceance basin the water rights for surface water and springs are held by various government agencies, irrigation companies, mineral companies, and ranchers.

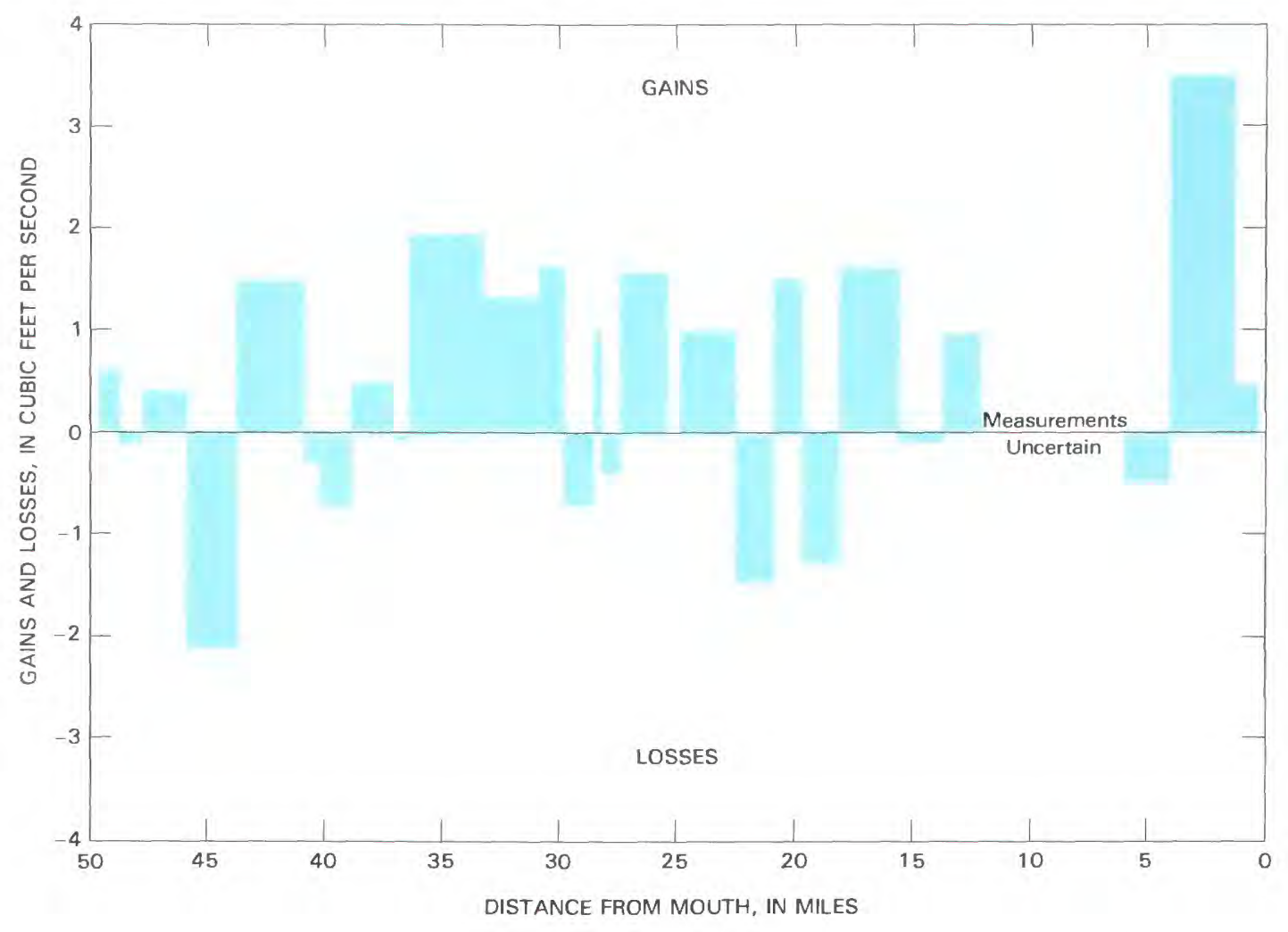

Gains and losses along selected reaches of Piceance Creek, March 26, 1981 (fig. 49). 

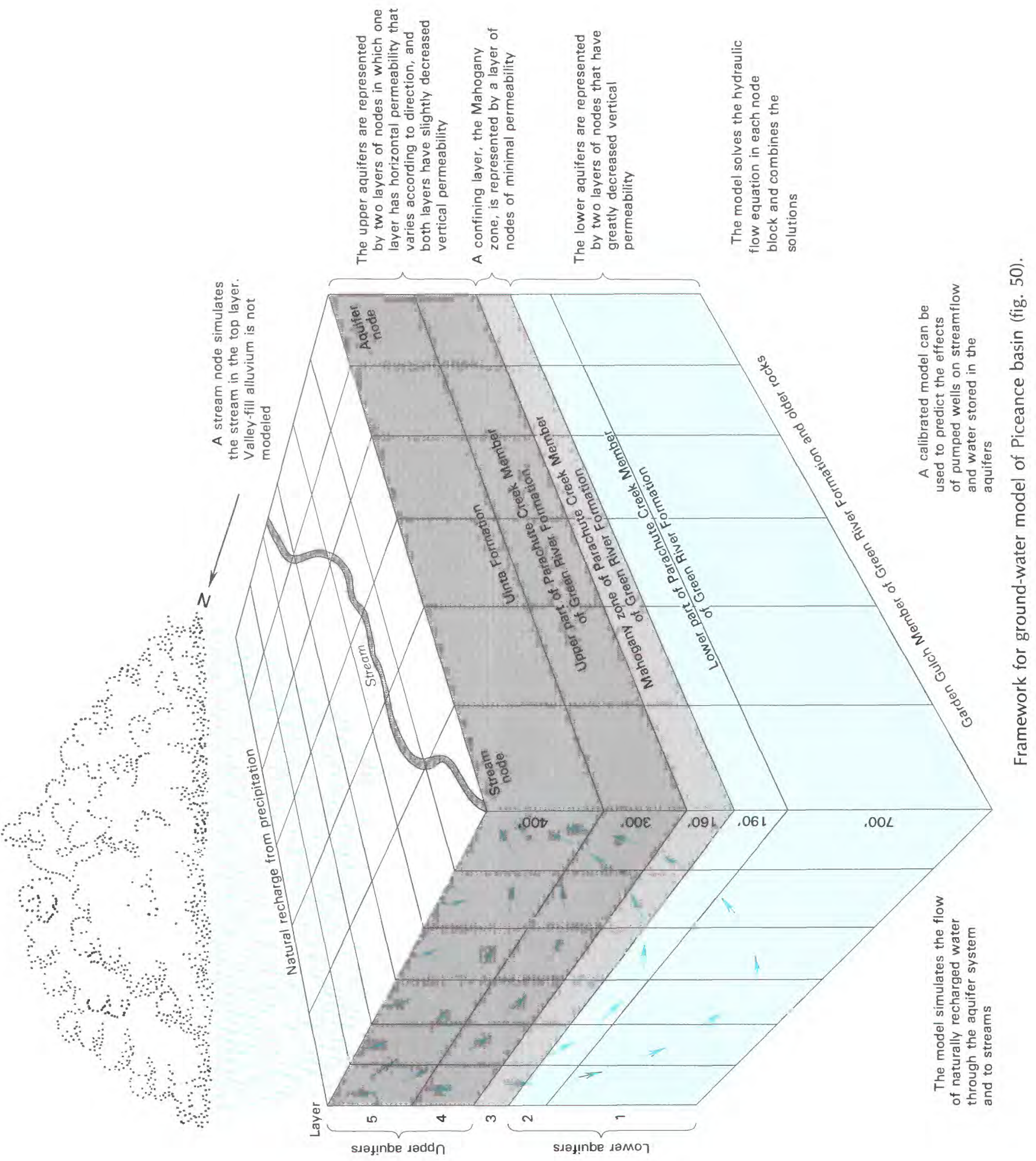


\section{GROUND WATER}

Colorado distinguishes between tributary and nontributary ground water in the administration of its groundwater resources. The Doctrine of Prior Appropriation applies to ground water that is hydraulically connected to streams. Water that naturally discharges from aquifers to streams is called tributary ground water because it contributes to streamflow as a tributary stream does to a larger stream. Wells completed in tributary aquifers probably derive pumped water from several sources:

1. Water in the aquifer that would otherwise discharge to the stream; this reduces streamflow.

2. Water from streams that is induced into the aquifer as a consequence of pumping; this also reduces streamflow.

3. Ground water in storage.

The sources of water described in items 1 and 2 affect appropriated water in the streams and therefore are regulated using the Doctrine of Prior Appropriation.

Ground water that does not discharge naturally into streams is called nontributary ground water. It is administered separately from tributary ground water. Nontributary ground water is administered by the State Engineer on the basis of the date of appropriation and the volume of water in storage in the aquifers. Those holding senior water rights (based on earlier dates of appropriation in that system) can pump water from wells in preference to those holding junior water rights (based on later dates of appropriation). However, in the absence of competing water rights, a landowner is allowed to pump, in any year, a maximum of 1 percent of the volume of ground water stored below his land. Therefore, the ground-water supply should last 100 years.

\section{SURFACE RESERVOIRS}

The Doctrine of Prior Appropriation also applies to surface reservoirs. Whether the reservoir is onstream or offstream, it may be filled only when the water right of the reservoir is in priority. As a general rule, reservoirs are allowed one filling annually.

\section{WATER FOR OIL-SHALE DEVELOPMENT WILL BE REGULATED BY THE STATE OF COLORADO}

Water supplies will be required for the development of oil shale and associated minerals. At least part of these supplies will be obtained from streams and springs, provided that an adequate water right is obtained by appropriation and adjudication. Alternatively, a water supply from a stream or spring might be obtained by:

1. Purchasing a water right;

2. Purchasing water from the owner of a water right; or

3. Purchasing water from another source that can be used to augment the flow of the stream or spring, thereby replacing the water taken illegally.

Water supplies also may be obtained using the water drained from the mines. However, in many areas, part of the water drained from the mines eventually will be depleted from the streams as a consequence of mine drainage. This depletion cannot interfere with the water rights of others; it must be allocated by means of a water right, purchased water, or augmentation plan.

Deep ground-water reservoirs that lie stratigraphically below the oil-shale aquifers also may furnish water for oilshale development. If these reservoirs are judged by the State Engineer of Colorado to contain nontributary ground water, the water will be allocated by the appropriate system of water rights, or by the rule that allows the pumpage of 1 percent of water stored in the ground-water reservoir in any year.

Surface-water reservoirs may be constructed in the Piceance basin to store water supplies and to insure that an adequate supply is available when needed. The filling of these reservoirs must be within the priority system.

\section{REFERENCES}

Redosovich, G. E., and Hamburg, D. H., compilers and eds., 1971, Colorado water laws, compacts, treaties, and selected cases; report prepared for Colorado State Engineer, Division of Water Resources, Colorado Department of Natural Resources: Denver, Colo., 205 p.

State Engineer of Colorado, 1978, Water rights inventory map for the oil shale development area of northwestern Colorado: Denver, Colo., 4 maps; scale 1:53,300.

Trescott, P. C., and Larson, S. P., 1976, Documentation of finite-difference model for simulation of three-dimensional ground-water flow: U.S. Geological Survey Open-File Report 76-591, 21 p.

U.S. Geological Survey, 1979, Water resources data for Colorado, Vol. 2. Colorado River Basin above Dolores River: U.S. Geological Survey Water-Data Report CO-79-2, 397 p.

1980, Water resources data for Colorado, Vol. 3. Dolores River Basin, Green River Basin, and San Juan River Basin: U.S. Geological Survey Water-Data Report CO-79-3, 438 p.

Weeks, J. B., Leavesley, G. H., Welder, F. A., and Saulnier, G. J., Jr., 1974, Simulated effects of oil-shale development on the hydrology of Piceance basin, Colorado: U.S. Geological Survey Professional Paper $908,84 \mathrm{p}$.

The water quality of a stream is determined by the suspended and dissolved constituents. The suspended sediment in Piceance Creek and possible erosional hazards related to mineral development in the basin are described in the following chapter. 


\title{
SUSPENDED SEDIMENT IN PICEANCE CREEK
}

\author{
BY VERNON W. NORMAN
}

Sediment is probably the most visible water-quality characteristic of streams in the Piceance basin. The more sediment suspended in the water, the more turbid or muddy the stream appears. In addition, the characteristics of the landscape, such as steep hillsides, valley floors, alluvial fans, and gullies are the result of sediment erosion, transport, and deposition.

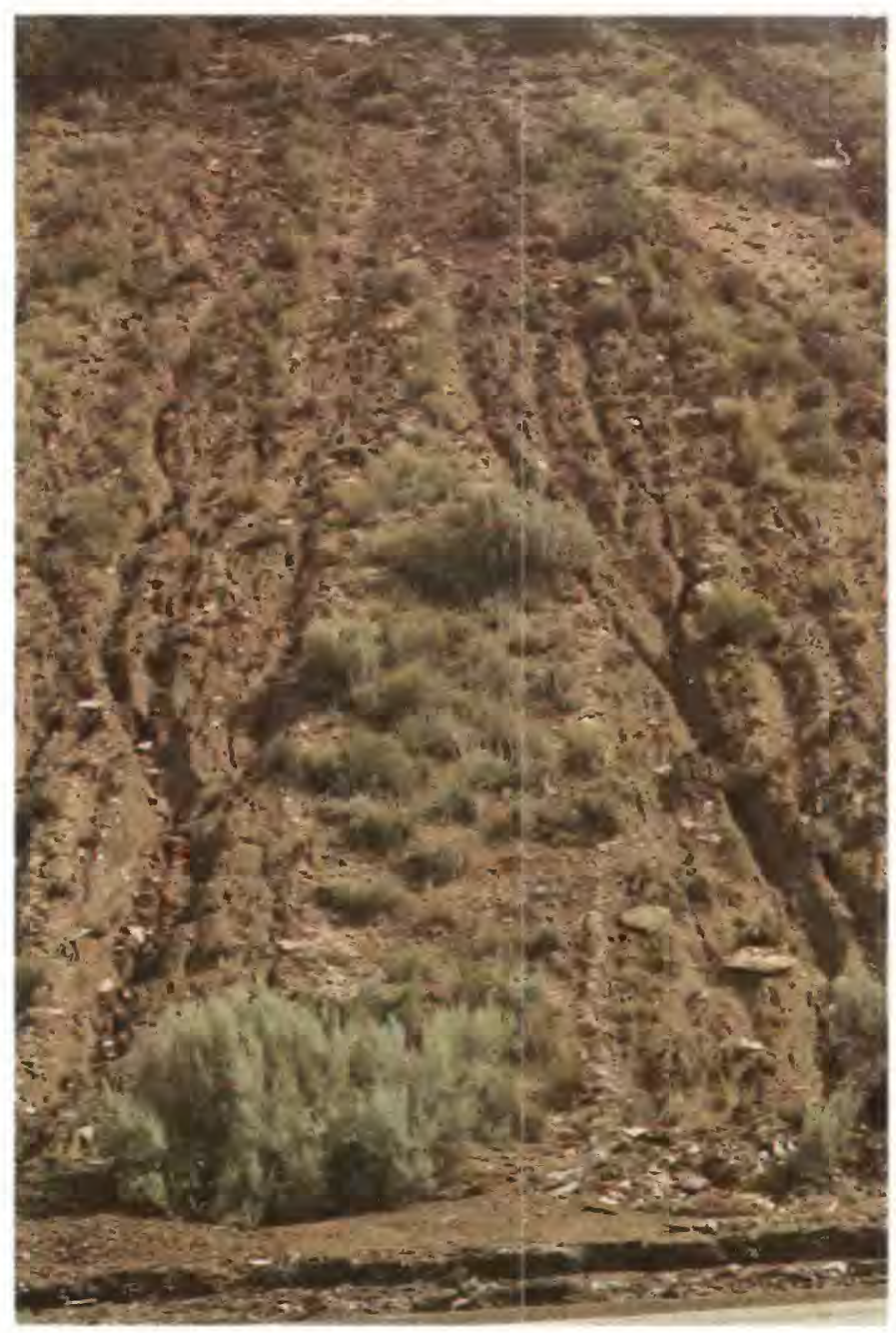

Hillside erosion near Rio Blanco after rainstorm, July 18, 1976 (fig. 51).
Erosion and the transport of suspended sediment by streams are natural processes that, in some circumstances, may have undesirable consequences:

1. The aquatic environment may deteriorate, which could damage or destroy life in the stream.

2. Water treatment may be required before the stream water can be used for some purposes.

3. Surface reservoirs may lose their storage capacity because of sediment deposition.

4. Toxic metals and organic substances that are relatively insoluble in water may be adsorbed on the surface of sediments and transported with the sediment.

5. The appearance of the stream is impaired.

\section{SEDIMENT TRANSPORT IS THE RESULT OF NATURAL PROCESSES}

Under natural conditions, sediment in the streams is derived from erosion of soils on the hillsides or from the bed or banks of the stream channels. Soils on the hillslopes are usually thin, and in many places have coarse particles on the surface. The coarse particles slow the erosion caused by rainfall. Hillslope soils erode readily only on steep slopes, during intense rainfall, or where the land has been disturbed. The sediment particles are carried to the streams by overland flow resulting from snowmelt during the spring or from rainstorms during the summer.

The banks of the main streams, such as Piceance and Black Sulphur Creeks, are generally composed of sand, silt, and clay particles that are less than about one-tenth of an inch in diameter. These materials erode easily when stream discharge increases due to snowmelt runoff or summer storms. Bank erosion is probably most prominent during the spring snowmelt when increases in stream discharge persist for many days. The bank material absorbs a large amount of water, becomes soft and easily removable, and sloughs into the stream in large clumps.

The streambed of Piceance Creek is composed of silt, sand, gravel, and occasional cobbles, with pockets of fine material where the velocity of the stream generally is slow. Coarse streambed materials normally move only during high flows in spring or during flooding from summer storms. 


\section{SEDIMENT TRANSPORT IN STREAMS DEPENDS ON THE AMOUNT AND DURATION OF STREAMFLOW}

Streams in the Piceance basin are either perennial (flow all year), intermittent (flow for 1 or 2 months during the spring), or ephemeral (flow only in response to rapid snowmelt or thunderstorms). The majority are ephemeral, and sediment carried by them commonly does not reach the major or perennial streams except as a result of large or intense storms. Ephemeral streams may carry sediment only short distances during each flood and also may deposit fans of material at their mouths on entering a larger valley or stream. Intermittent streams may carry the sediment much farther downstream because their flow is sustained for several weeks. Perennial streams carry the sediment much farther and can transport most of the fine particles out of the basin in a few days. The coarse sand and larger particles move more slowly and require years, decades, or longer to move through the streams and out of the basin.

Daily sediment records have been collected since 1974 at 24 sites in the Piceance basin. The annual total sediment loads at these sites range from 0 to more than 290,000 tons. Zero values are recorded for years in which an ephemeral stream did not flow. The greatest load was measured at the mouth of Yellow Creek during an extreme flood; more than 99 percent of the 290,000 tons passed the site within 7 hours on September 7, 1978. During the period of record, perennial streams have transported from 100 to 60,000 tons per year.

If the drainage area above a gaged site is known, the sediment yield in tons per square mile can be determined and used to compare the volumes of sediment from different areas. In basins drained by perennial streams, sediment yields generally range from 20 to 80 tons per square mile; average yields from most basins are about 30 tons per square mile. In basins drained by ephemeral streams, measured volumes range from 0 to 170 tons per square mile during a short period of record. These volumes are about 10 times smaller than the sediment yields predicted for the same areas before the yields were measured. The difference probably is due to the large volume of sediment that was eroded but will not reach the streams except during an extreme flood. Consequently, if sediment yields are measured for a longer period that includes some extreme floods, measured yields may be closer to predicted yields.

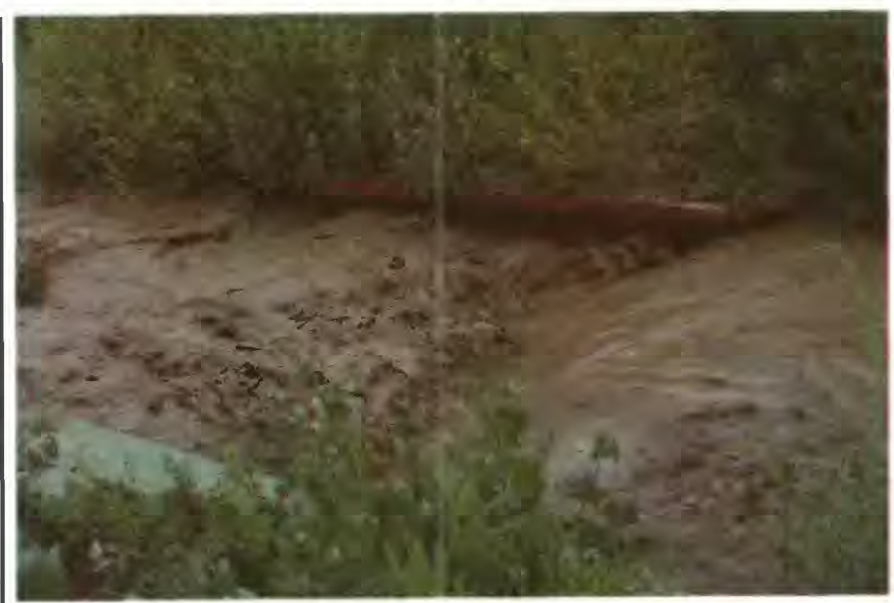

Turbid water in Piceance Creek near Rio Blanco, July 17, 1977 (fig. 52).

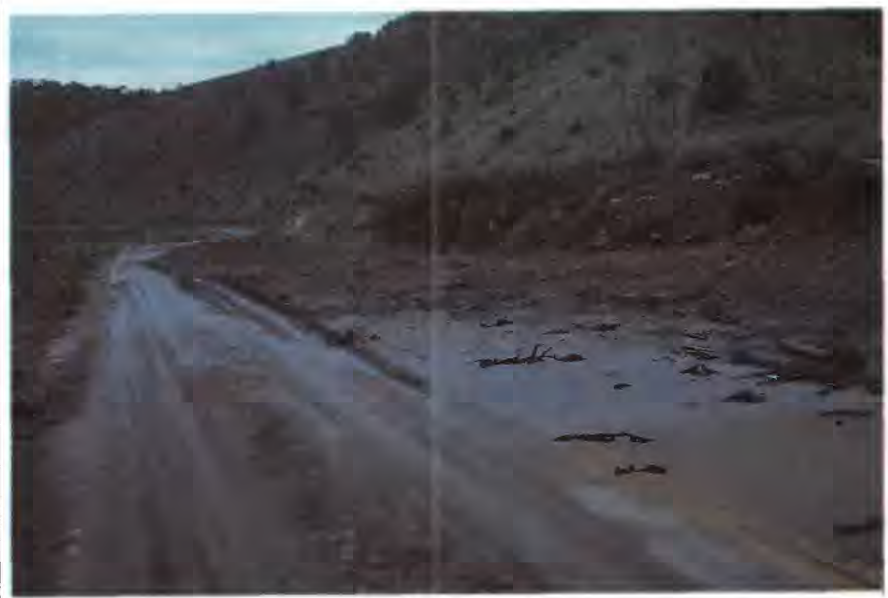

Coarse sediment deposited on highway near Piceance Creek during intense rainstorm, July 19, 1977 (fig. 53).

\section{THE SEDIMENT AND CHANNEL CHARACTERISTICS OF THE PICEANCE BASIN ARE UNUSUAL}

Some characteristics of sediment in the Piceance basin are unusual. For example:

1. Much of the sediment of sand size and larger is flat, plate shaped, and of low density. Streams can carry this material farther than they carry more spherical grains. 

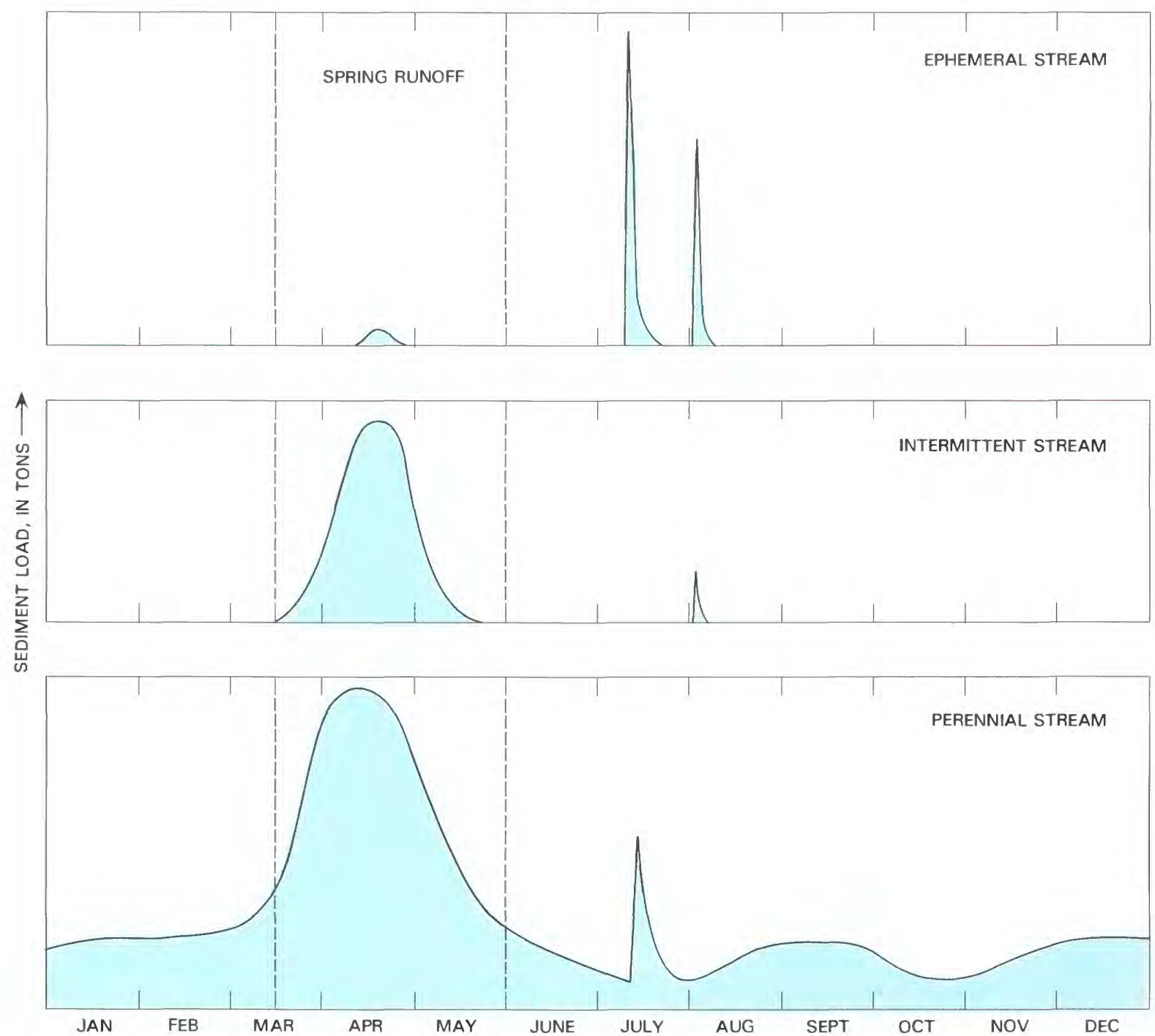

Typical yearly distribution of sediment load in streams in the Piceance basin (fig. 54).

2. Gullies caused by erosion of the valley floors are discontinuous and deep and do not extend the full length of the valley.

3. Streambeds eroded by clear water from mine-drainage wells and settling ponds have vertical banks because the horizontal plate-like particles form a rigid structure that erodes more easily from the sides than from the top.

\section{SEDIMENT TRANSPORT RELATED TO MINING AND WASTE DISPOSAL NEEDS TO BE CONTROLLED}

Mining development and waste-disposal activities may increase erosion and result in increased sediment transport. For example, surface mining and underground mining create temporary piles of stored waste material that may or may 


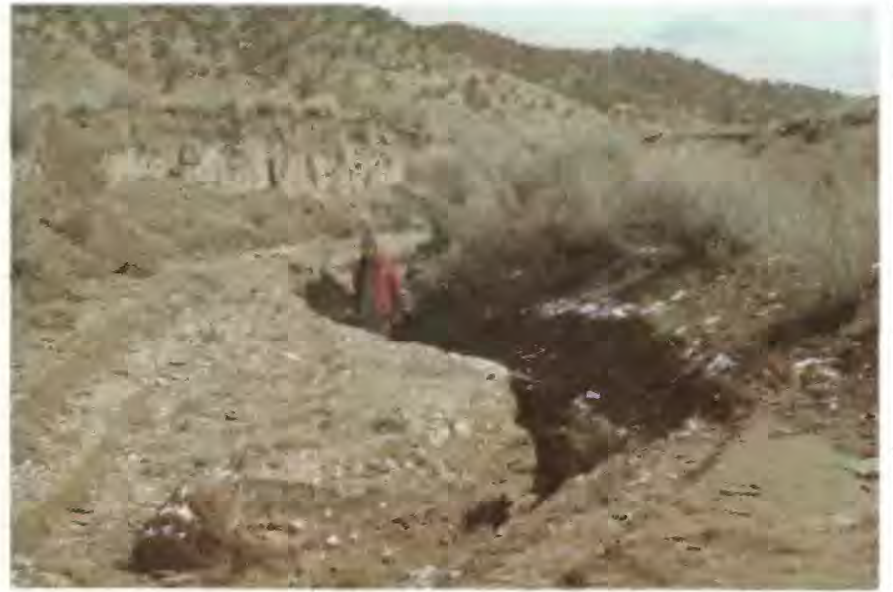

Deeply cut channel in streambed of Corral Gulch, resulting from well discharge, April 3, 1978 (fig. 55).

not be backfilled after mining activities are complete. The waste material stored on the land surface or backfilled into open-pit mines is more easily eroded than the undisturbed soil mantle.

A spoil pile of retorted oil shale may be finely pulverized material, which also will be easily eroded. This material is different from the natural sediment that reaches streams in size, shape, composition, and ability to adsorb metals and organic substances.
Reclamation procedures to insure that sediment-transport problems do not develop include:

1. Placement of waste material in spoil piles that have flat shapes to reduce erosion.

2. Construction of settling ponds to intercept surface runoff passing over easily eroded materials.

3. Compaction of backfilled waste material and spoil piles in order to decrease the erosion.

4. Replacement and revegetation of soil over backfilled waste material or spoil piles.

A dense vegetation cover greatly reduces erosion.

The chemical effects of spoil piles are discussed in the chapter "Chemical effects and control of leachates from oilshale spoil piles."

\section{REFERENCES}

Frickel, D. G., 1978, Hydrologic and geomorphic data from the Piceance basin, Colorado, 1972-77: U.S. Geological Survey Open-File Report 78-825, 169 p.

Frickel, D. G., Shown, L. M., and Patton, P. C., 1975, An evaluation of hillslope and channel erosion related to oil-shale development in the $\mathrm{Pi}$ ceance basin, northwestern Colorado: Colorado Water Resources Circular $30,37 \mathrm{p}$.

The dissolved constituents in ground water and streams result from various chemical processes related to the hydrologic flow system. Relations between the dissolved constituents and the flow system are described in the following chapter. 


\title{
WATER QUALITY IN THE PICEANCE BASIN
}

\author{
BY ROBERT L. TOBIN
}

\section{PERCOLATING GROUND WATER DISSOLVES MINERALS FROM THE UINTA FORMATION, GREEN RIVER FORMATION, AND VALLEY-FILL ALLUVIUM}

Snowmelt and rain recharge the bedrock aquifers and replenish the ground water that migrates through the Uinta and Green River Formations. As the water percolates through these formations, minerals are dissolved and ionexchange reactions occur.

In the northern part of the basin, the ground waters and their dissolved minerals discharge to springs, streams, and valley-fill alluvial aquifers in various reaches of the Piceance and Yellow Creek valleys. The exact location and extent of hydrologic connections between aquifers and streams are not well known. In the southern part of the basin, the Uinta and Green River aquifers discharge to springs, some of which contribute to streamflow in the Roan and Parachute Creek valleys. Throughout the basin, water in the valleyfill alluvial aquifers also dissolves minerals from the alluvium, undergoes ion-exchange reactions, and in some places discharges to surface water.

\section{DISSOLVED MINERALS DIFFER IN THE TWO MAJOR BEDROCK AQUIFERS OF THE UINTA AND GREEN RIVER FORMATIONS}

The water chemistry of the upper bedrock aquifers is dominated by dissolved calcium, magnesium, and bicarbonate along the rim of the basin; and by sodium, magnesium, bicarbonate, and sulfate in the central part of the basin. These constituents are characteristic of water in the upper aquifers, principally the Uinta Formation. Sodium and bicarbonate are the dominant dissolved constituents in the water from the upper Parachute Creek Member of the Green River Formation, at the base of the upper aquifers. The total concentration of dissolved constituents in the upper aquifers generally is lower than 1,000 milligrams per liter. Characteristic trace elements include strontium in concentrations of several milligrams per liter in the Uinta Formation, and fluoride in concentrations of greater than 1 milligram per liter in water samples from the lower part of the upper aquifers.

The principal dissolved constituents in water from the lower bedrock aquifers are sodium and bicarbonate. The total concentration of dissolved constituents may range from slightly less than 1,000 milligrams per liter along the rim of the basin to perhaps 10 or 20 times higher near the northcentral part of the basin. These high concentrations result from contact of water with the ancient evaporite deposits of nahcolite, dawsonite, and halite associated with the Green River Formation. The trace element fluoride also has been detected in unusually high concentrations, ranging from 10 to 30 milligrams per liter in the lower aquifers. The trace elements barium, boron, and lithium are abundant in the lower aquifers where chloride concentrations also are greater than several hundred milligrams per liter.

Methane and hydrogen sulfide gases have been detected in many wells that penetrate the aquifers of the Green River Formation. These gases probably are generated in the upper and lower aquifers from the alteration of organic matter in an oxygen-depleted environment.

\section{WATER QUALITY IN PICEANCE AND YELLOW CREEKS IS AFFECTED BY WATER DISCHARGED FROM AQUIFERS}

Within the Piceance and Yellow Creek drainage basins, the quality of the surface water and ground water are related, except during periods of extensive runoff due to storms and snowmelt, when streams are freshened. During other periods, approximately 80 percent of the annual flow of $\mathrm{Pi}$ ceance and Yellow Creeks originates as discharge from alluvial and bedrock aquifers. During steady-flow conditions on March 26, 1981, analysis of the major dissolved constituents at numerous sites in Piceance Creek generally indicated increases in the downstream direction. The concentrations of dissolved solids, bicarbonate, sulfate, and sodium increased due to the discharge of water from the bedrock aquifers to the stream valley and tributaries.

The Piceance Creek has been divided into reaches; the flow regime in each is generalized by comparing the calculated gains and losses of flow (fig. 58) with changes in stream quality. The total load of dissolved constituents in Piceance Creek increased from about 1.5 tons per day near the headwaters of the stream to about 122 tons per day near the mouth. The increase in volume of dissolved constituents in the downstream direction indicates that Piceance Creek is transporting large quantities of dissolved minerals into the White River valley. 

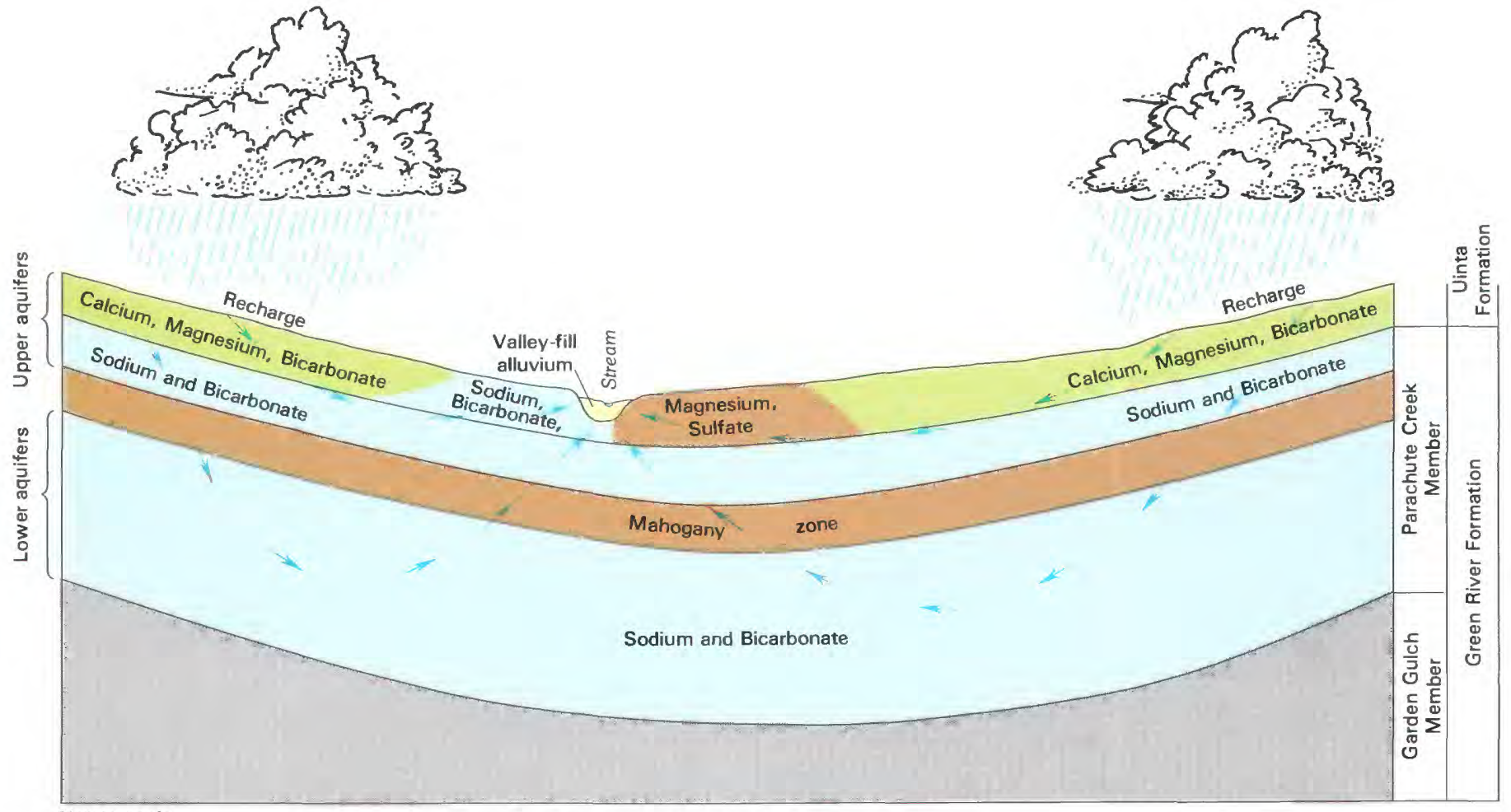

Not to scale

MAJOR IONS
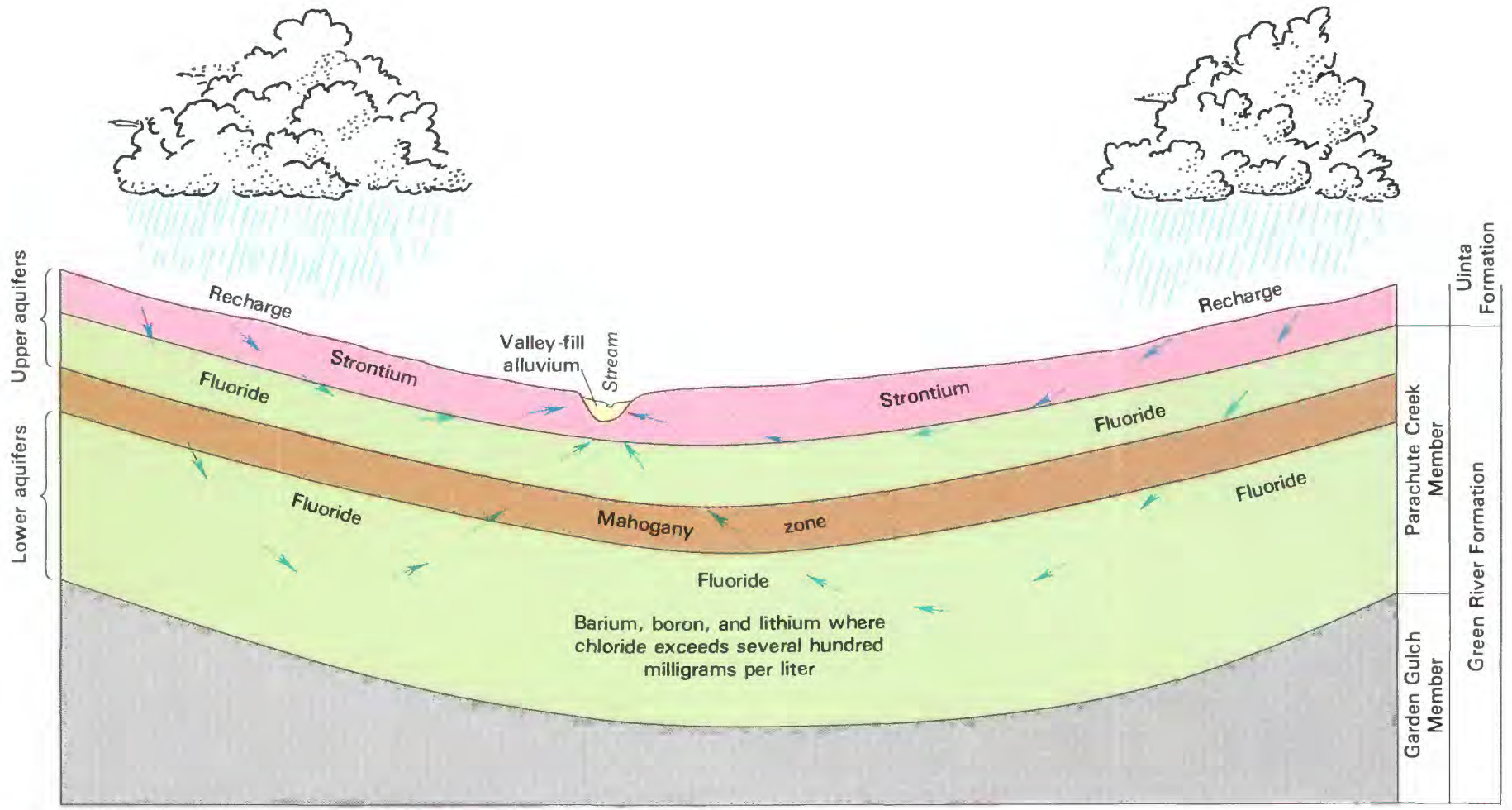

Not to scale

TRACE ELEMENTS

Dominant chemical constituents in the two major bedrock aquifers (fig. 56). 
In the Alkali Flats area, several miles downstream from Dry Fork, the bicarbonate concentration in Piceance Creek increases by several hundred milligrams per liter. This change in surface-water quality is caused by the discharge of ground water upward through an extensive fracture zone. Salts precipitated on the land surface by evaporation of the shallow ground water are visible for many miles during the low-flow season. A similar area of precipitated salts is found near the mouth of Yellow Creek. During periods of higher flows, the accumulated salts on the flood plains are flushed into Piceance and Yellow Creeks.

The water-quality patterns in Piceance Creek are easily observed during intermediate and low-flow conditions in the winter and nonirrigation periods. Substantial changes in dissolved-solids composition and concentrations are observed during the periods of intense surface runoff and during the irrigation season. Dissolved-solids concentrations generally are much lower during intense runoff because they are diluted by precipitation; concentrations are considerably higher during the irrigation season because of the addition of minerals dissolved by water applied to fields.

The effects of mine drainage on water quality at tracts $\mathrm{C}-\mathrm{a}$ and $\mathrm{C}-\mathrm{b}$ (fig. 23) were analyzed using a solute-transport model. The analysis did not consider the disposal of water drained from mines-only the hydrologic and chemical effects of the pumping on the aquifers and streams. The model predicted that mines at tract $\mathrm{C}$-a could be drained by pumping only the lower bedrock aquifers; the water in the upper bedrock aquifers would drain downward in response to pumping the lower aquifer. The quality of the ground water in the lower aquifers near tract C-a would improve with pumping because the less mineralized water in the upper aquifers would dilute the more mineralized water in the lower aquifers. Pumping also reduces the period of contact between the water and soluble minerals and results in less solution compared to natural conditions. Distant from tract C-a the model predicted total dissolved constituents that are related to changes in the flow system caused by pumping.

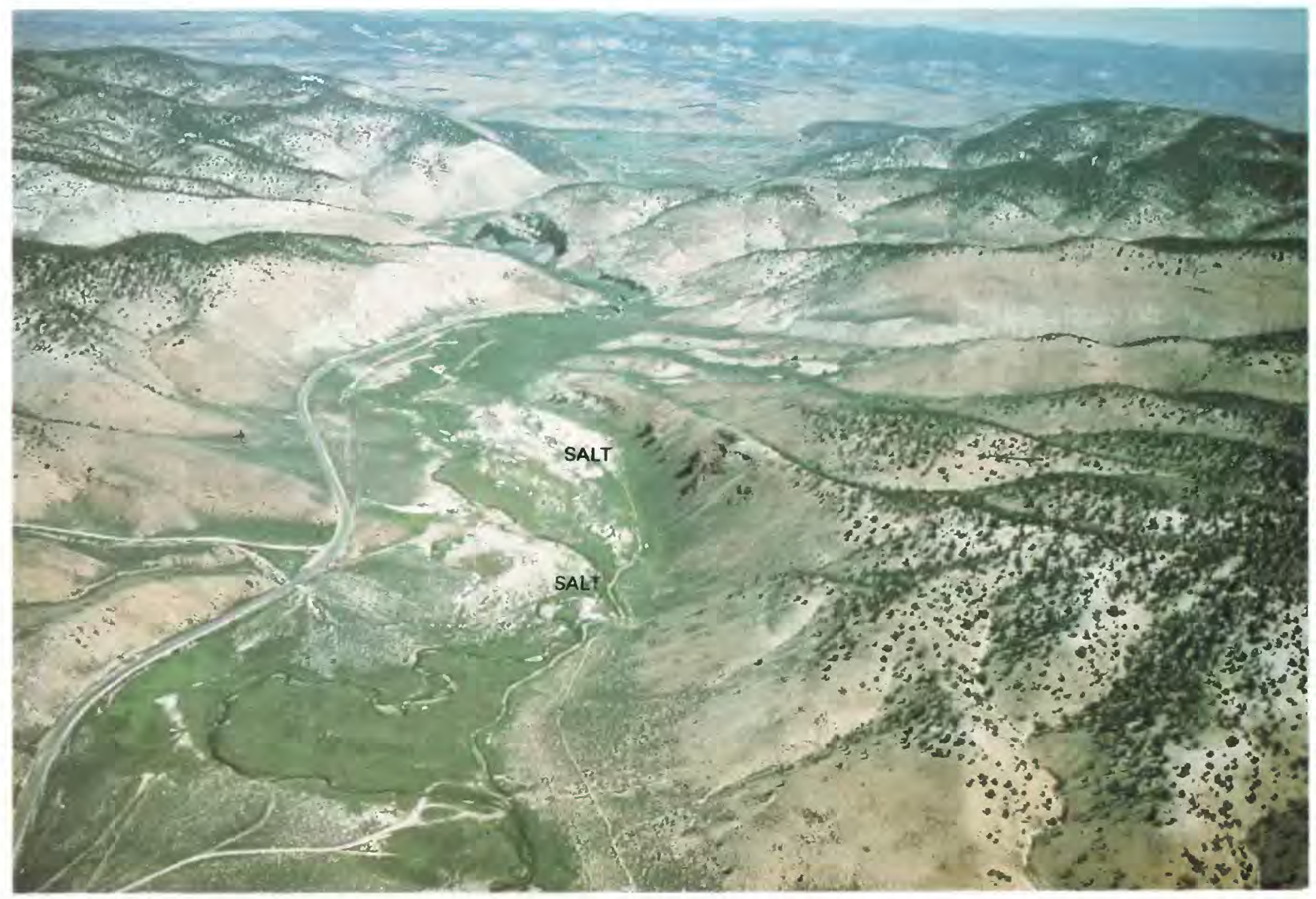

Alkali flats, marked by white salts on the land surface in Piceance Creek valley, with White River valley in the background (fig. 57). 
aNOJ

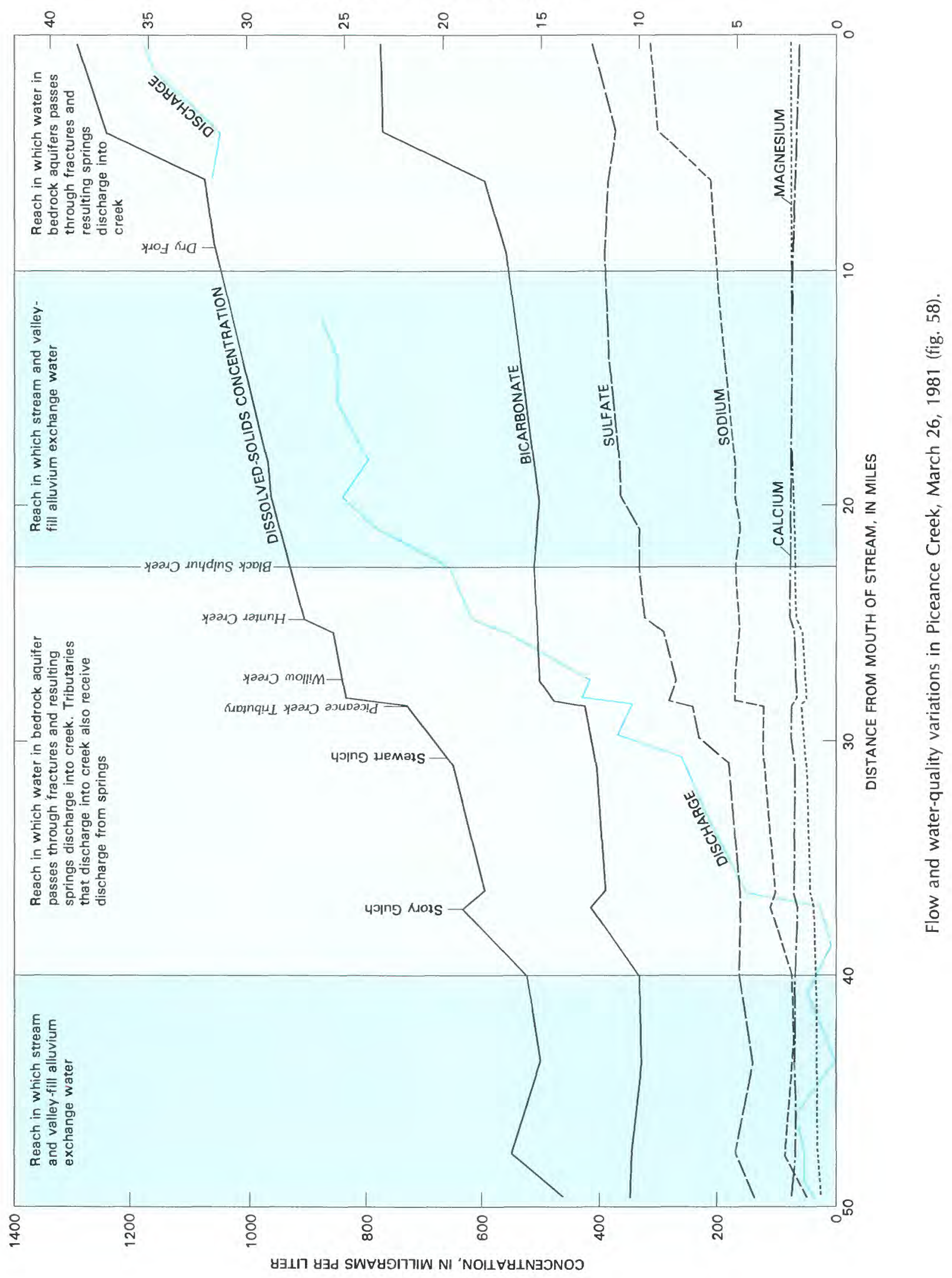


At tract $C-b$, the model predicted that:

1. Both bedrock aquifers would need to be pumped to drain the mines, and

2. The changes in water quality in the bedrock aquifers would be similar to the changes at tract $\mathrm{C}$-a.

A reduction in streamflow and an increase in dissolved solids in most reaches of the streams also were predicted by the model. After mining activity is completed, the pumps will be shut off and the hydrologic system will recover. The model also was used to predict the effects of solution by water flooding the abandoned mines. The model indicated that solution of soluble minerals in the abandoned in situ retorts will increase the dissolved-solids concentrations in ground water near the mines, especially in aquifers of high permeability.

\section{REFERENCES}

Robson, S. G., and Saulnier, G. J., Jr., 1980, Hydrogeochemistry and simulated solute transport, Piceance basin, northwestern Colorado: U.S. Geological Survey Professional Paper 1196, 65 p.

Weeks, J. B., Leavesley, G. H., Welder, F. A., and Saulnier, G. J., Jr., 1974, Simulated effects of oil-shale development on the hydrology of Piceance basin, Colorado: U.S. Geological Survey Professional Paper 908, $84 \mathrm{p}$.

Welder, F. A., and Saulnier, G. J., Jr., 1978, Geohydrologic data from twenty-four test holes drilled in the Piceance basin, Rio Blanco County, Colorado, 1975-76: U.S. Geological Survey Open File Report 78-734, $132 \mathrm{p}$.

A study of organisms in streams provides a rapid method of appraising the health of a stream and its ability to sustain higher forms of plant and animal life. A description follows of some of the organisms in Piceance Creek. 



\title{
APPRAISAL OF WATER QUALITY IN PICEANCE CREEK USING BENTHIC INVERTEBRATES
}

\author{
BY KENNETH J. COVAY
}

The water quality of a stream depends on the dissolved and suspended constituents in the water. Periodic sampling and analyses of these constituents is one way to assess the stream quality. Another method is to relate the response of living organisms in the aquatic environment to natural and man-induced changes in water quality. For example, benthic invertebrates (animals lacking a backbone, such as insects) respond to contamination. In particular, short-term exposures to contamination, which might not be detected by chemical sampling, may be discovered in samples of benthic invertebrates because the effects of changes in water quality on organisms persist for several weeks or months.

\section{BENTHIC INVERTEBRATES ARE IMPORTANT FORMS OF LIFE IN THE AQUATIC ENVIRONMENT}

The aquatic environment is host to a variety of organisms ranging from the lowest forms of microorganisms, such as bacteria and algae, to the higher forms of plants and animals, including insects and fish. The bottom of a stream is a habitat for all these types of life, of which benthic invertebrates are one of the most important. Bottom-dwelling organisms primarily consist of the immature forms of insects, but also include noninsects such as snails, clams, scuds, water mites, worms, and leeches.

Benthic invertebrates are a significant link in the aquatic food chain - they occupy a place in the transfer of food between the primary source, plants, and the end of the food chain, man or similar animals. Benthic invertebrates are the primary source of food for fish and other aquatic vertebrates. Water-quality degradation or loss of benthic habitat will interrupt feeding patterns and cause an instability in all aquatic populations and communities.

\section{BENTHIC INVERTEBRATES CAN BE USEFUL IN ASSESSING WATER-QUALITY CONDITIONS}

Among the methods used to assess the water-quality conditions in streams is the analysis of bottom-dwelling animals.
Benthic invertebrates are good indicators of water quality because they are:

1. Sensitive to changes in their environment.

2. Somewhat immobile, and thus do not easily move away from areas of contamination.

3. Relatively long lived and able to reflect temporary contamination that is difficult to detect by chemical sampling.

Different benthic invertebrates are associated with different water-quality conditions. Immature forms of caddisflies, stoneflies, and mayflies usually are found in uncontaminated water because they require substantial concentrations of dissolved oxygen. Worms, leeches, and some immature two-winged flies can survive in water containing very little dissolved oxygen, and large numbers of these organisms commonly are found in contaminated streams. Groups of benthic invertebrates indicate water quality because different types of benthic invertebrates are associated with different water conditions. For example, changes of benthic-invertebrate groups compared to relative changes in concentration of dissolved oxygen are illustrated below.

Dissolved oxygen, however, is not the only factor that influences the establishment of benthic-invertebrate communities. The community is a result of the interactions between numerous physical and chemical factors. For example, stream-bottom characteristics, stream velocity, water temperature, dissolved substances, and the incidence of droughts and floods are all factors that regulate the occurrence and distribution of benthic invertebrates.

In a stream that is not contaminated, benthic communities usually consist of many different types of benthic invertebrates with no single type particularly dominant. A contaminated stream might contain only a few types with many individuals of each type. The benthic invertebrates living in the contaminated water are those that can tolerate such conditions. In general, members of the two-winged fly order have greater tolerances to extremes in water-quality conditions than do members of other groups. As previously mentioned, the presence of only a few organisms such as worms and leeches also indicates contaminated water. 


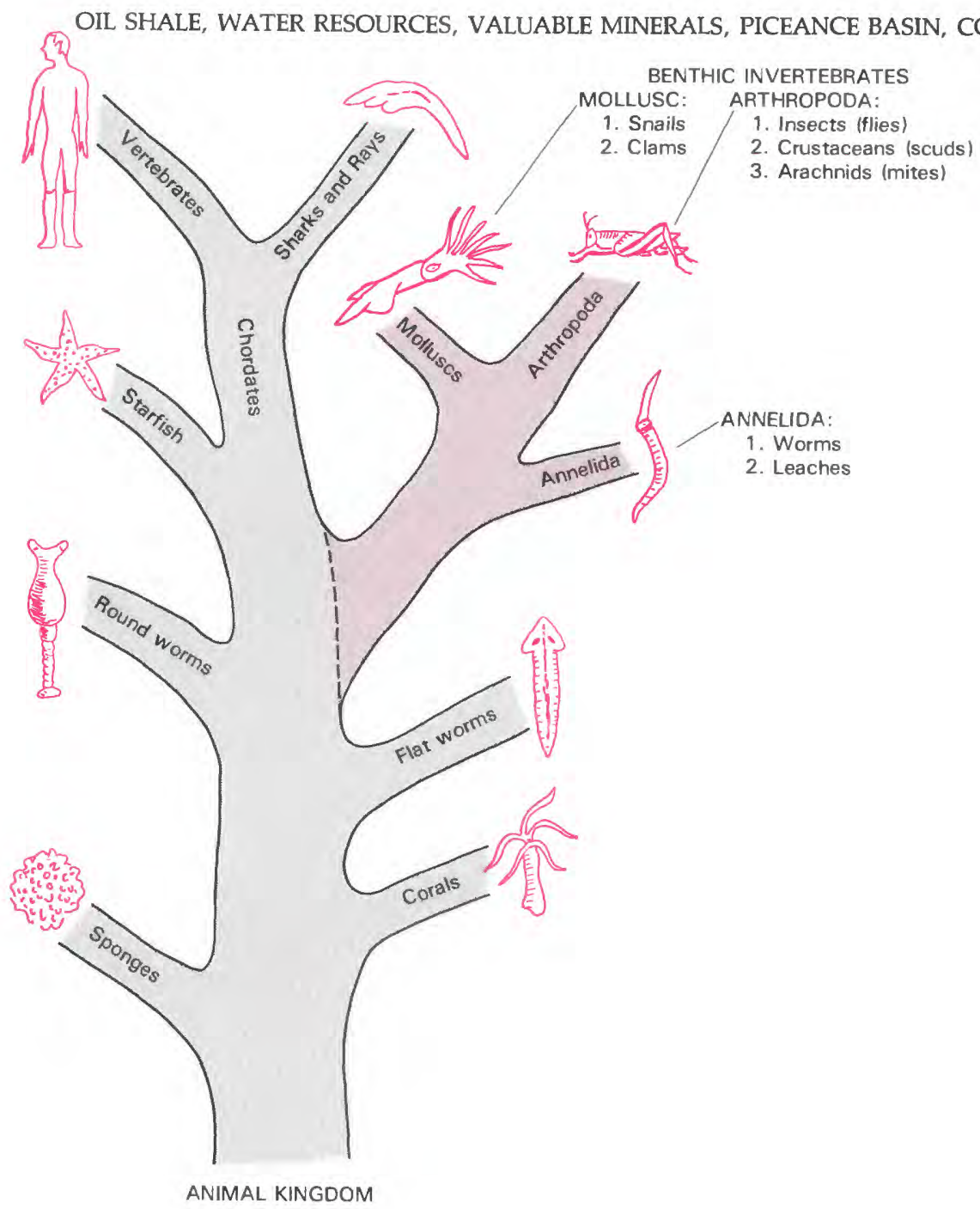

Benthic invertebrates as part of the animal kingdom (fig. 59).

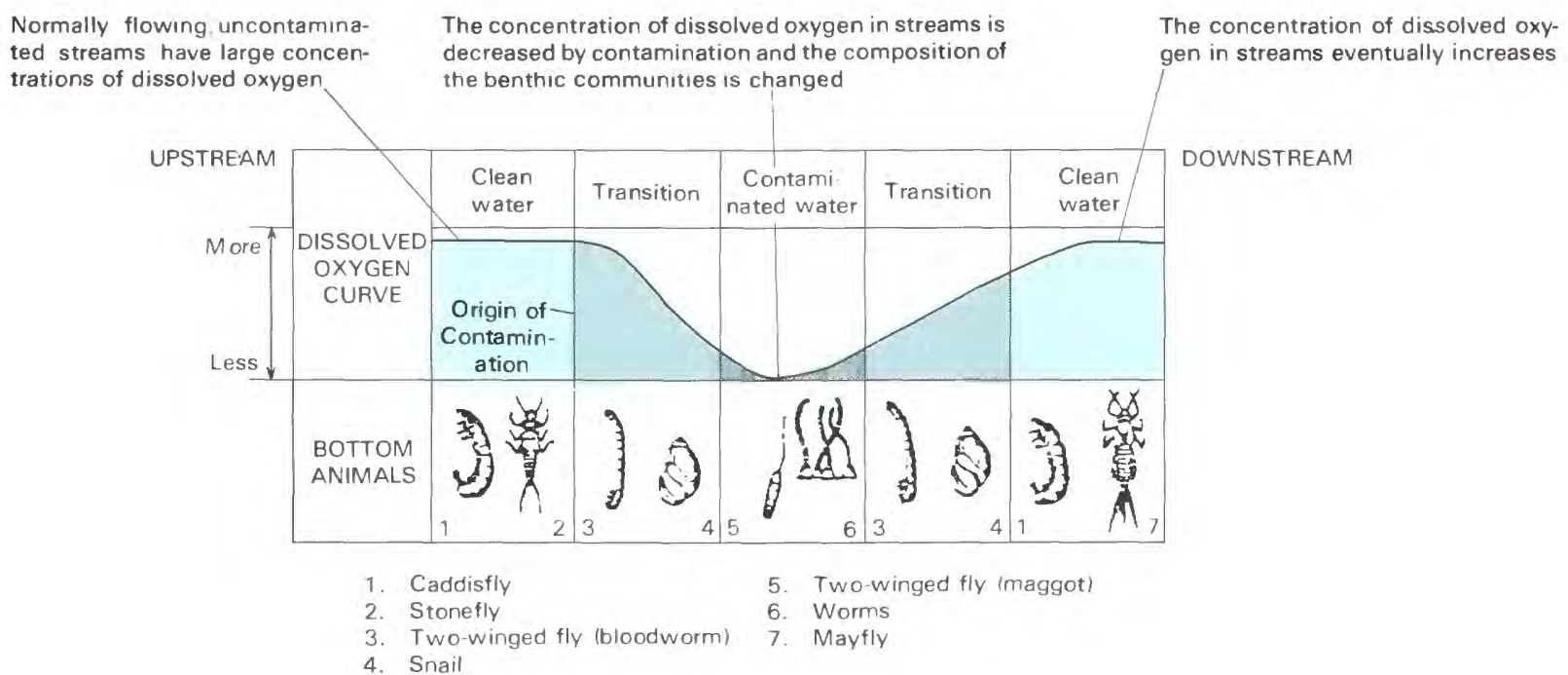

Changes in dissolved-oxygen concentration in streams and related changes in groups of benthic invertebrates (fig. 60). 

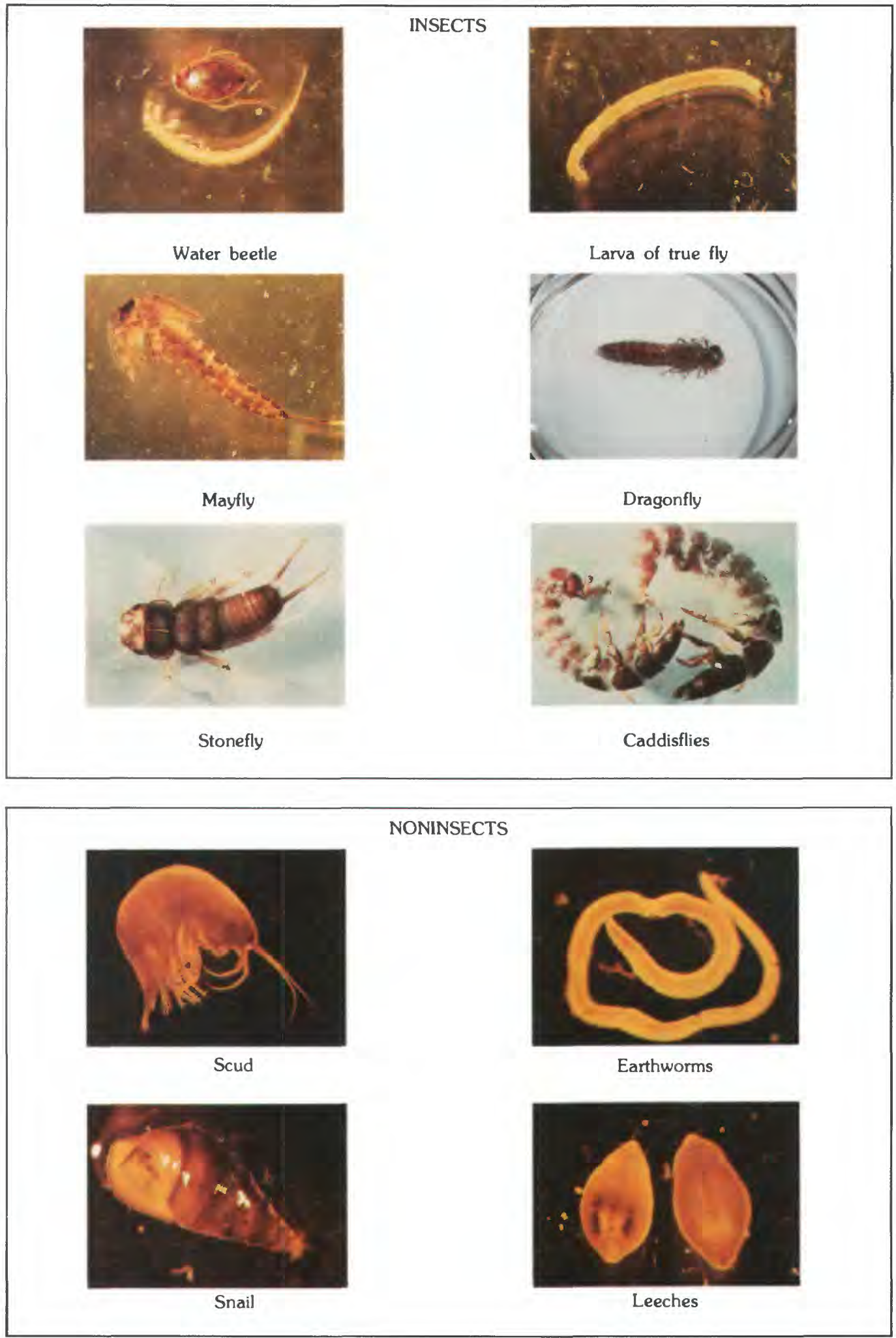

Benthic invertebrates that live in the bottom of streams (fig. 61). 


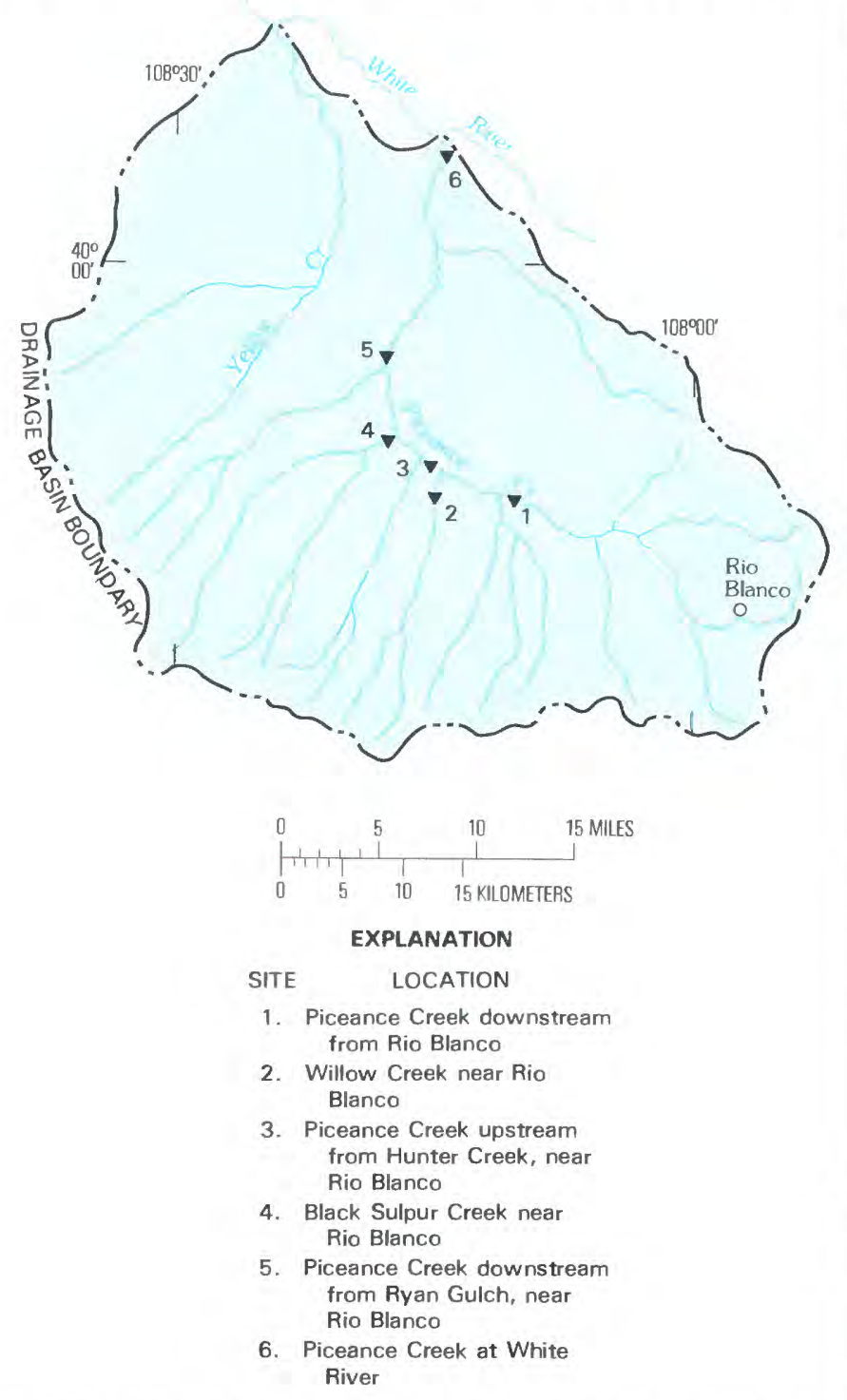

Samples of benthic invertebrates collected at six locations in the Piceance Creek basin (fig. 62).

\section{TYPES OF BENTHIC INVERTEBRATES IN THE PICEANCE BASIN}

Samples of benthic invertebrates were collected at six locations along Piceance Creek. Approximately 26 samples were collected at each location-mostly during the summer and fall. The composition of these samples is illustrated using circular graphs. Each graph indicates the proportion of major insect and combined noninsect groups and permits comparison between sites. Insect groups identified in the Piceance basin are the two-winged flies, mayflies, stoneflies, caddisflies, beetles, true bugs, and dragonflies. Noninsect groups identified are aquatic worms, scuds, snails, water mites, and leeches. The site number for each circular graph is keyed to the site number on the map.
The circular graphs show a gradual increase in twowinged flies in Piceance Creek in the downstream direction from site 1 (downstream from Rio Blanco) to site 6 (at White River). This increase probably can be attributed to chemical changes in the water and physical changes in the bed materials. For example, during the summer months when land is irrigated, the concentration of dissolved solids increases downstream because the irrigation water dissolves minerals from the soil and alluvium as it returns to the stream. The concentration of dissolved solids can be three times greater at site 6 than at site 1 because of the irrigation water return flow and the natural discharge of bedrock and alluvial aquifers to the stream.

Downstream increases in sodium, bicarbonate, and sulfate are major contributors to the increases in dissolved solids. Concentrations of ammonia, boron, and, at times, fluoride, also increase at site 6 . The streambed at site 6 is composed of finer sized materials than at site 1 , contributing to increasing stream turbidity and suspended-sediment concentrations downstream.

The composition of benthic invertebrates at sites along Piceance Creek normally does not vary greatly from season to season. However, during intense periods of runoff, the communities may be changed or destroyed by the scour resulting from increases in stream discharge and deposition of sediment. Also, the communities may become dormant during sustained periods of cold weather.

\section{DISCHARGE OF OIL-SHALE WASTES INTO STREAMS OF PICEANCE BASIN MAY CHANGE THE COMPOSITION OF THE BENTHIC-INVERTEBRATE COMMUNITY}

It has been shown that the composition of benthic communities is affected by changes in water quality. However, the effects of oil-shale development on benthic-invertebrate communities have not been fully determined.

Oil-shale development is likely to cause increased concentrations of suspended sediment, organic compounds, dissolved solids, and various inorganic compounds such as ammonia, boron, and fluoride. These constituents are discussed in the chapters "Suspended sediment in Piceance Creek," "Water quality in the Piceance Basin," "Chemical effects and control of leachates from oil-shale spoil piles," and "Chemical effects and control of wastes from in situ retorts."

Changes in the physical and chemical characteristics of stream water due to oil-shale development will likely result in changes in the composition of the benthic-invertebrate community. This is based on the fact that the increase of dissolved-solids concentration and suspended sediment downstream coincides with an increase in tolerant organisms of the two-winged fly order and a decrease in less-tolerant organisms. 

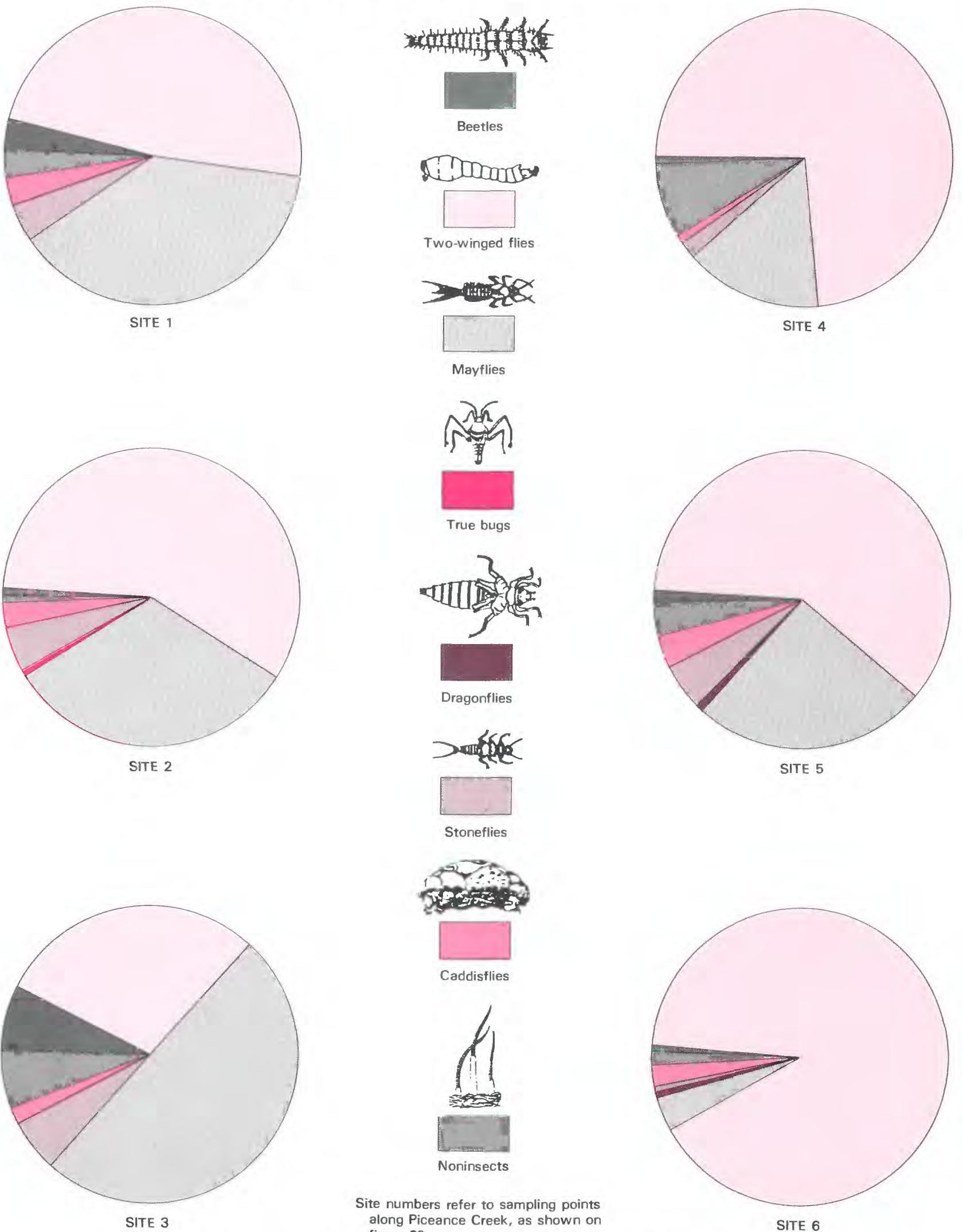

Stoneflies
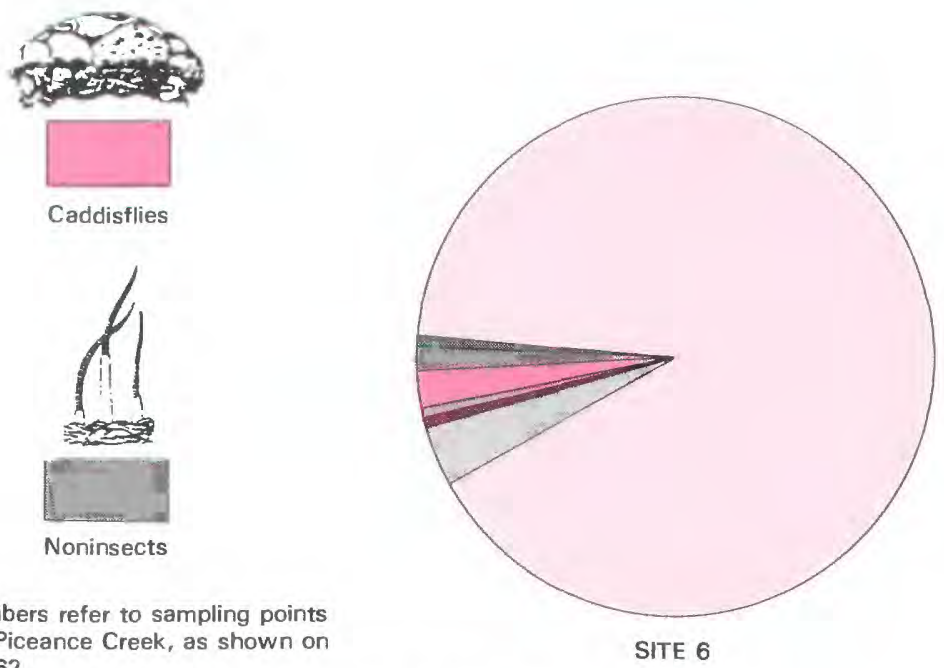

Proportions of benthic organisms along Piceance Creek (fig. 63). 
Water needed for oil-shale development may be taken | regional aquifers that occur stratigraphically beneath the oil from local streams and pumped from mines during drainage shale and associated minerals, as indicated by the followactivities. Additional water supplies may be developed from $\mid$ ing discussion. 


\section{PLANNING FOR MINERAL DEVELOPMENT: ALTERNATE WATER SUPPLIES AND EFFECTS OF RETORTS}





\title{
PALEOZOIC AND MESOZOIC FORMATIONS AND THEIR POTENTIAL AS GROUND-WATER RESERVOIRS
}

\author{
BY MARJORIE E. MACLACHLAN and FRANK E. WELDER
}

\section{DEEP GROUND-WATER RESERVOIRS MAY BE USED TO FURNISH WATER SUPPLIES OR TO STORE WASTEWATER}

Development of oil shale and associated minerals, accompanied by related population and industrial growth, will increase water demands in northwestern Colorado. Cost estimates are as much as one billion dollars for providing a water supply from streams and surface reservoirs. Preliminary hydrologic studies of the Green River and Uinta Formations in the Piceance basin indicate that millions of acre-feet of ground water may be present in these underground reservoirs. However, deep ground-water reservoirs that may lie stratigraphically beneath the Green River Formation in Paleozoic and Mesozoic formations have not been explored or tested for storage, yield, and water quality.

A thorough understanding of all potential aquifers, deep and shallow, will allow the most economical development of new supplies. Exploratory drilling may locate large ground-water reservoirs and reduce the need for the construction of costly dams, canals, pipelines, and pumping stations that are required for surface-water supplies. Deep ground-water reservoirs may not only constitute a valuable alternative or supplemental water supply, but also can serve as possible storage sites for injected wastewater.

\section{GEOLOGIC EVIDENCE INDICATES THAT DEEP FORMATIONS IN PICEANCE BASIN MAY BE AQUIFERS}

Exploratory drilling for oil and gas along the margins of structural basins of northwestern Colorado has provided limited information on the subsurface characteristics of the geologic formations. Additional studies have been made of formations exposed at the surface. The information indicates that aquifers of Paleozoic and Mesozoic age may lie adjacent to the Piceance basin, at depth within the Piceance basin, and in northwestern Colorado in general. The range in depth of these aquifers resulted from erosion and from the structural deformation described in the chapter "General geology of the Piceance basin."

A discussion of the sedimentary sequence of Paleozoic and Mesozoic formations follows. It includes descriptions of the water-supply potential of several formations based on geologic and hydrologic information.

\section{PALEOZOIC AND MESOZOIC FORMATIONS ARE SHOWN ON THREE STRATIGRAPHIC COLUMNS}

Different types of Paleozoic and Mesozoic rocks are found in different places around the margins of the Piceance basin. Three stratigraphic columns show their sequence, age, name, rock type, and thickness along the Grand Hogback, on the east side of the Piceance basin; near the Yampa River, north of the Piceance basin; and near Grand Junction, on the southwest side of the Piceance basin.

Unconformities that are shown in the stratigraphic columns indicate that certain formations and parts of formations are missing. Attempts to drill exploratory holes to certain formations need to take into account nearby stratigraphic columns, to be certain that the formation interval is present beneath the drilling site. Unconformities also separate the oldest unit shown in each of the three columns from underlying Precambrian rocks. The youngest unit shown in each column is unconformably overlain by Tertiary rocks that are discussed in the chapter "General geology of the Piceance basin." About 25,600 feet of Paleozoic and Mesozoic rock is represented in the composite section along the Grand Hogback, about 11,600 feet of Paleozoic and Mesozoic rock is found near the Yampa River, and about 10,400 feet of Mesozoic rock (the Paleozoic is absent) is present near Grand Junction. 
TABLE 4.-Correlation chart showing Paleozoic and Mesozoic formations

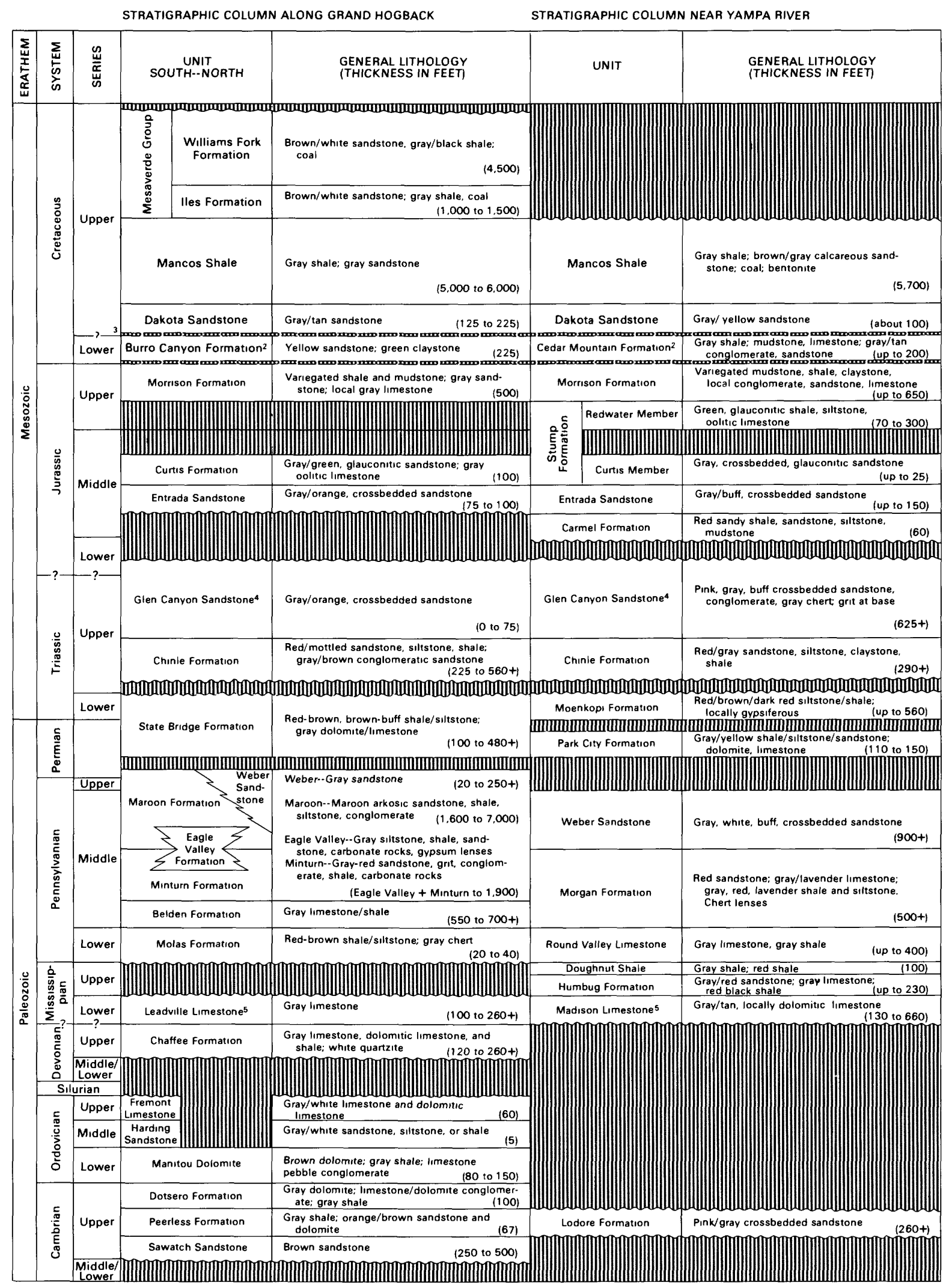


TABLE 4.-Continued

STRATIGRAPHIC COLUMN NEAR GRAND JUNCTION

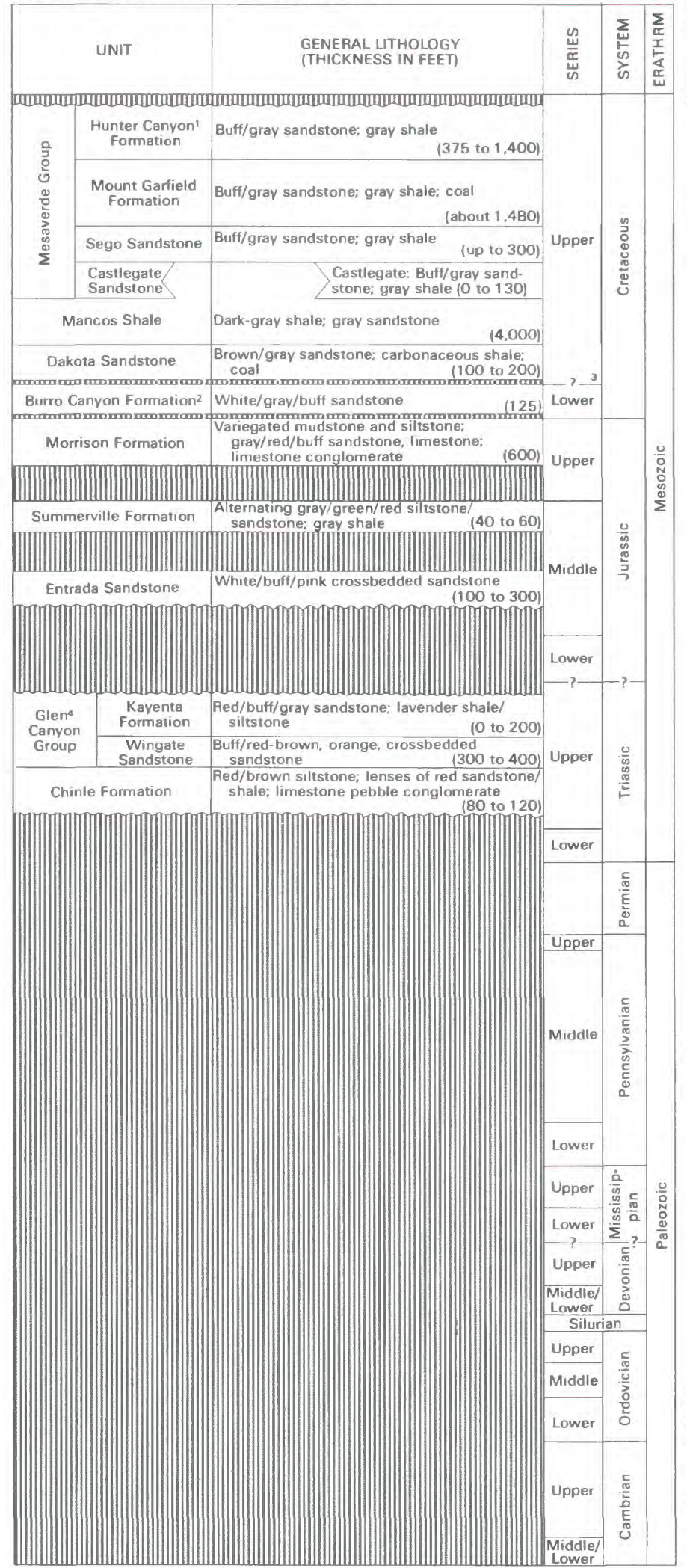

Wavy lines indicate unconformities; dashed lines indicate uncertain age ranges; and vertical lines show gaps in record]

SOURCES OF INFORMATION:

ALONG GRAND HOGBACK

Bass and Northrop 1963: Bryant, 1979; Gaskill and Godwin, 1966: Imlay. 198D: Johnson, May. Hansley, Pitman, and Fouch, 1980; MacLachlan, Tweto, 1976: Tweto, Moench, and Reed, 1978.

NEAR YAMPA RIVER

Imlay, 1980; Hansen, 1965; Hansen and Carrara, 1980; Maclachlan, 1972 .

NEAR GRAND JUNCTION

Cashion, 1973: Imlay, 1980; Johnson and May. 198D; Lohman. 1965: Mac'The Ohio Creek member was recently assigned to the Hunter Canyon For-
mation as its upper member (Johnson and May, 1980 ). This member formerly we distinguished from the Mount Garfield Formation by the character of the gray, and more massive than those in the Mount Gartield Formation.

2The name Cedar Mountain Formation is used north of the Colorado A the name Burro Canyon Formation is used south of the Colorado River. The boundary between the Upper and Lower Cretaceous Series is

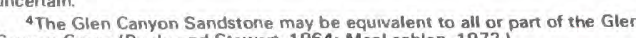

${ }^{5}$ The geographic boundary between use of Madıson Limestone and Leadville Limestone is uncertain. 

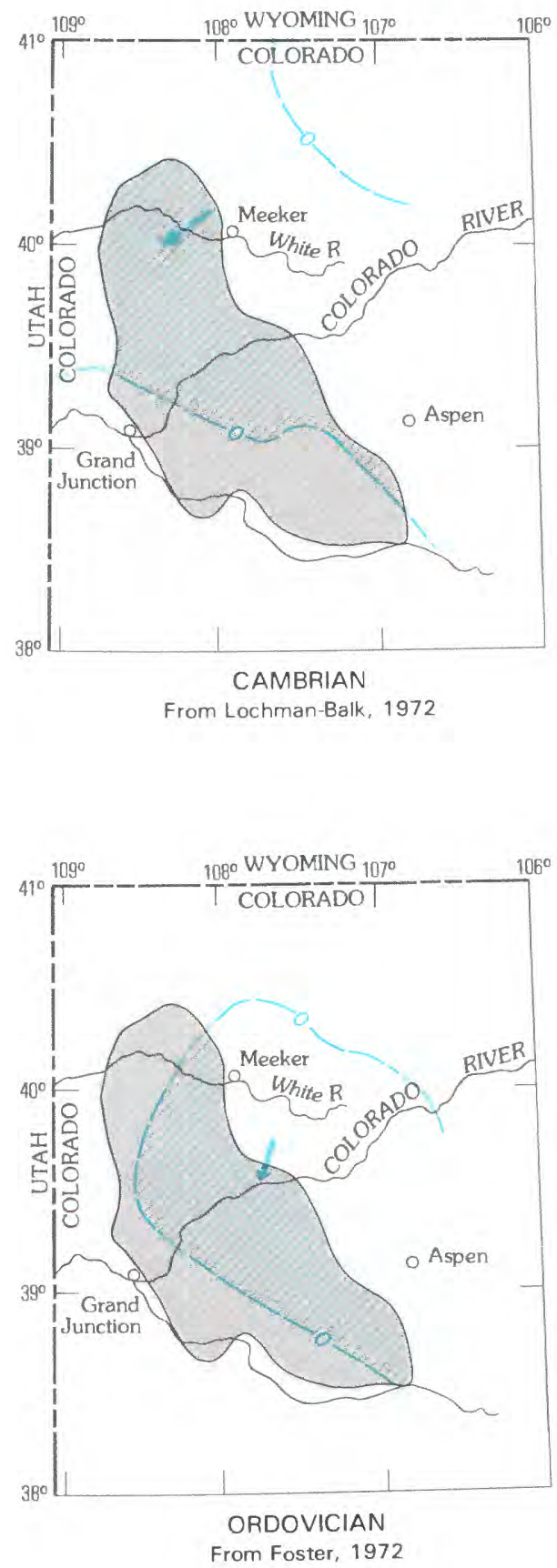

\section{THE AREAL EXTENT OF PALEOZOIC AND MESOZOIC FORMATIONS IS SHOWN ON A SERIES OF MAPS}

The distribution of Paleozoic and Mesozoic rocks under the Piceance structural basin is shown for each system. The shaded areas represent the present extent of the rocks of each period within the basin; extensive parts have been eroded away. Rocks of seven of the periods (Cambrian, Ordovician,
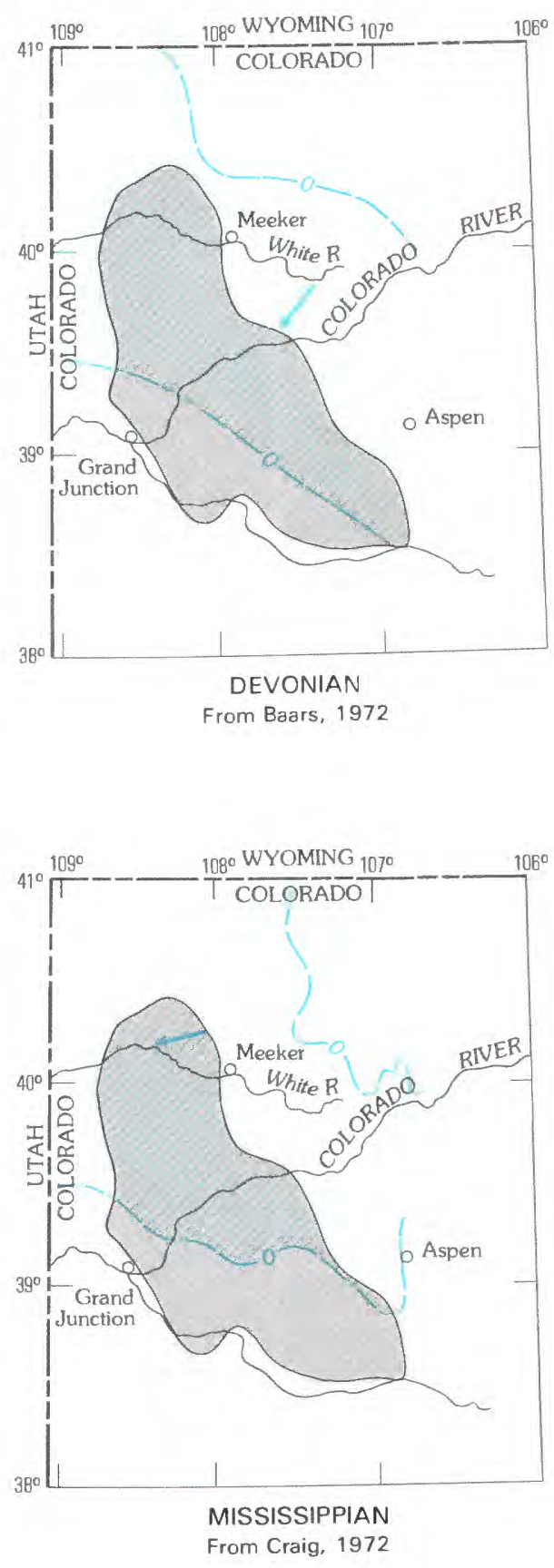

and Devonian through Triassic) probably underlie more than one-half of the basin area. Silurian formations are absent. Jurassic and Cretaceous rocks probably underlie the entire basin area.

\section{CAMBRIAN}

The oldest Paleozoic formations are of Late Cambrian age and are found in the northern part of the basin. Rock types include sandstone, dolomite, and shale, all deposited in a 


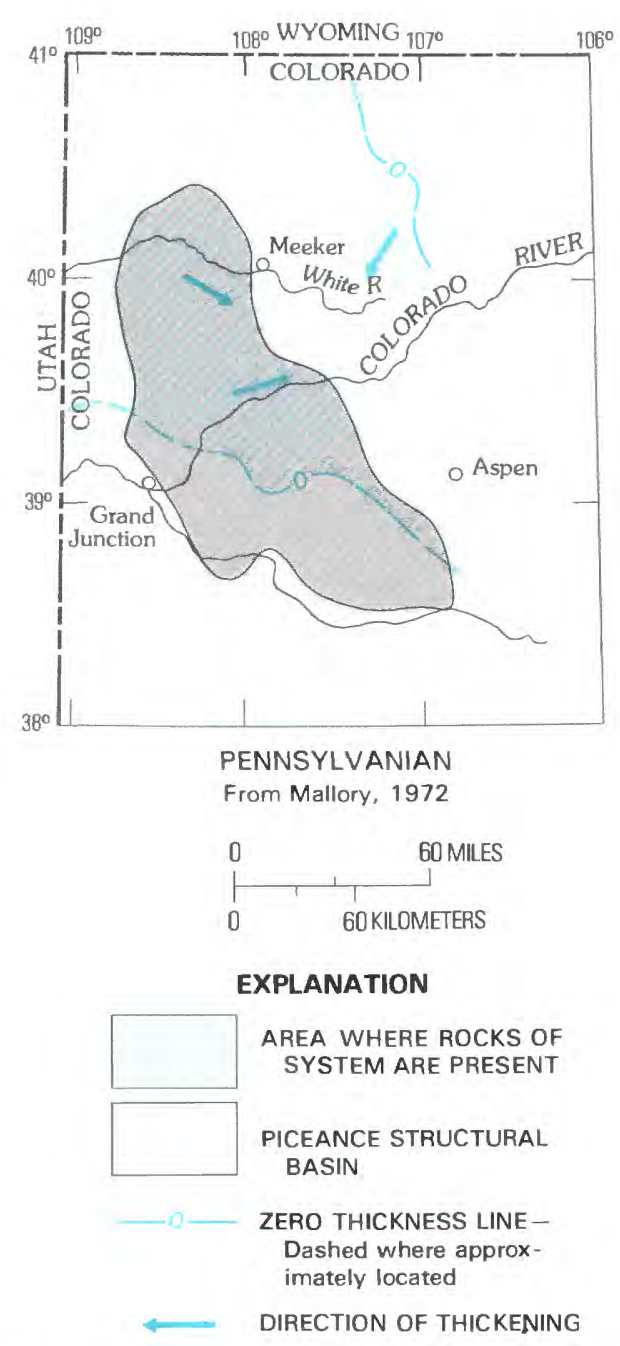

marine environment. The Dotsero Formation is of more limited areal extent than the overlying formations because it is confined to the White River uplift area. Cambrian rocks thicken generally southwestward across the basin to a maximum of about 700 feet near the Utah border.

\section{ORDOVICIAN}

The Ordovician rocks are marine deposits that thicken southward toward the Colorado River. The Manitou Dolomite thickens southward to more than 200 feet near Aspen. The Harding Sandstone and Fremont Limestone thin toward the east; they probably are missing from a significant part of the basin.

\section{DEVONIAN}

Marine sedimentation recommenced in Late Devonian time after an intervening erosional period of about 85 million years where the Chaffee Formation overlies the Fremont

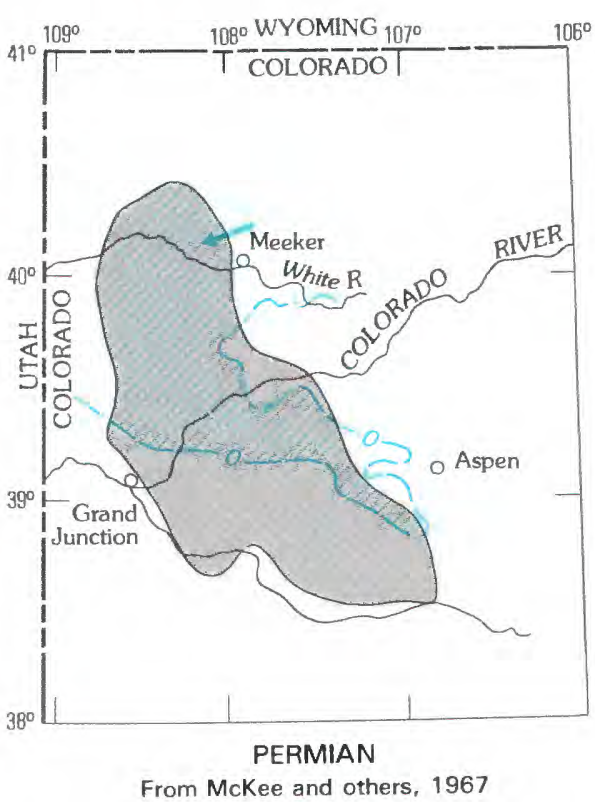

Distribution of Paleozoic rocks under the Piceance structural basin (fig. 64 above and facing page).

Limestone, and of about 140 million years where the Chaffee Formation rests on the Lower Ordovician Manitou Dolomite. The lower part of the Chaffee Formation is a basal quartzite overlying dolomite, shale, and quartzite. The upper part of the Chaffee Formation is limestone and dolomite; it is locally sandy and conglomeritic. The formation attains a maximum thickness of about 300 feet.

The formations of Cambrian, Ordovician, and Devonian age may include aquifers within the sedimentary sequence of limestone, dolomite, sandstone, and shale. However, the potential for obtaining water supplies from these formations has not been investigated.

\section{MISSISSIPPIAN}

Lower Mississippian marine carbonate rocks of the Leadville or equivalent Madison Limestone account for most of the Mississippian age rocks in the basin. Upper Mississippian shale, limestone, and sandstone of the Humbug Formation and Doughnut Shale underlie only the northwesternmost part of the basin. The Mississippian thickens westward to about 600 feet near the Utah border. 


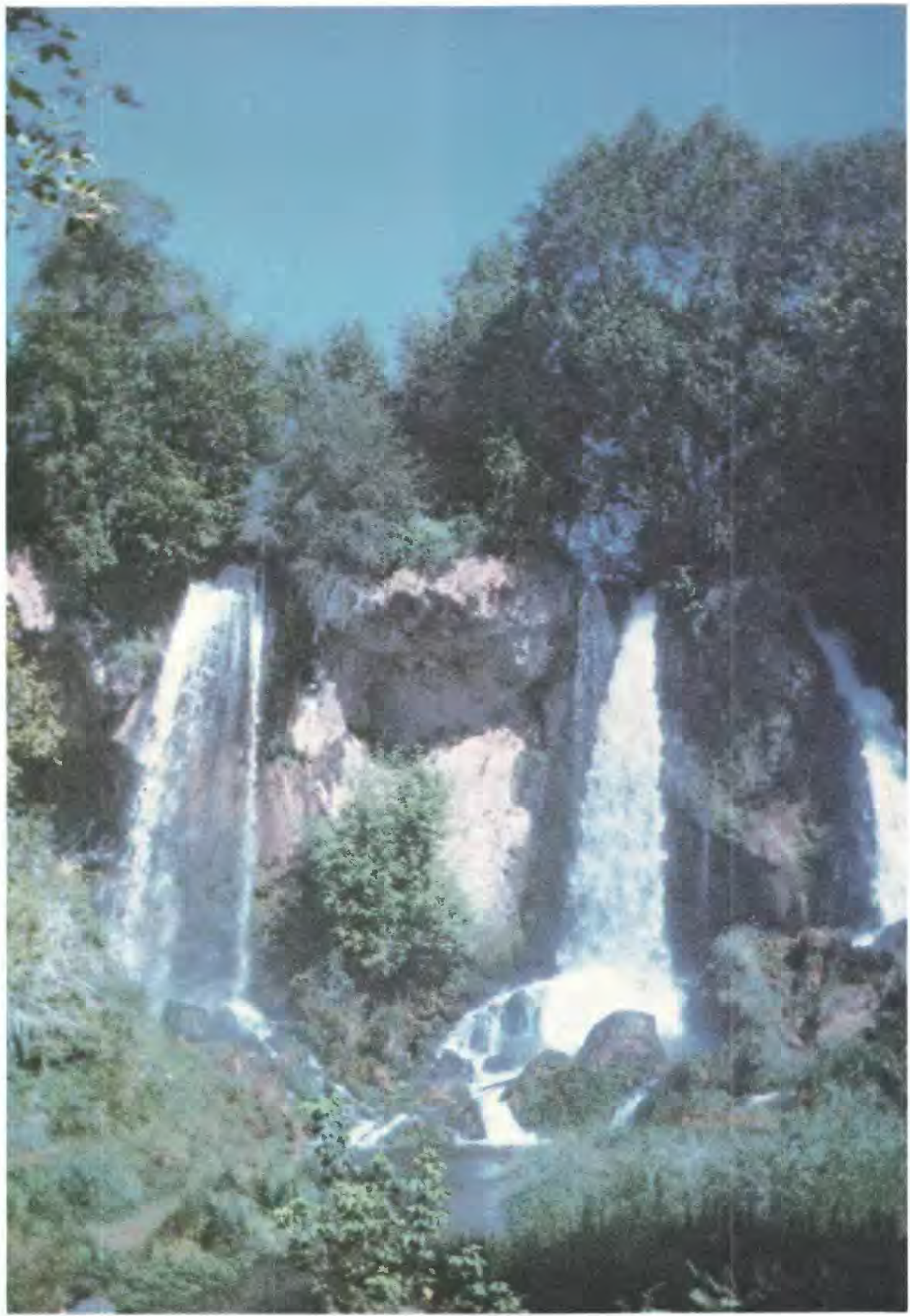

Water draining from the Leadville Limestone, flowing into Rifle Creek and over Rifle Falls (fig. 65). 
Water movement and chemical solution have increased the porosity and permeability of the Leadville or Madison Limestones more than that of other formations. Exposures of the formations contain caves, fractures, mineral-lined cavities, and springs. A 9,360-foot deep oil well near Rangely, Colo., reportedly yielded saltwater under pressure from the Madison Limestone. If the formation is recharged by precipitation in the White River uplift, it may store and transmit large quantities of water below the oil-shale deposits of the Piceance basin. In the White River uplift, the Leadville Limestone is partly drained by Rifle Creek; during lowflow conditions, most of the flow of the creek is water from the Leadville. The water in Rifle Creek flows over Rifle Falls in a spectacular display.

\section{PENNSYLVANIAN}

The Pennsylvanian was a time of change from a shallow water, marine deposition in earlier Paleozoic to deposition in small basins. Thick sequences of marine limestone and shale in the lower part of the Pennsylvanian were succeeded by evaporitic and coarse-grained clastic rocks in the upper part. The Uncompahgre uplift, south of Grand Junction, was a source area for the clastic rocks. One small basin just east of the Piceance structural basin contains more than 10,000 feet of Pennsylvanian rock.

Sandstone formations of Pennsylvanian age and those of the overlying Permian sequence may constitute an aquifer system. A program of drilling, aquifer testing, and sampling is needed to appraise the potential of these sandstone formations.

\section{PERMIAN}

Rocks of the Permian Period underlie most of the northern two-thirds of the basin. The total thickness of the Permian rocks probably does not exceed 500 feet. Permian formations were deposited in shallow seas (Park City Formation) and on adjacent lowlands (Weber Sandstone, upper part, and Maroon Formation, upper part).

The Weber Sandstone is fractured, porous, and probably permeable. Exploratory oil tests using holes drilled near Meeker, Colo., yielded warm, salty water from the Weber Sandstone. Other sandstone formations of Permian age may be aquifers.

\section{TRIASSIC}

Triassic rocks were deposited in three different environments. The Moenkopi Formation at the base is a nearshore marine deposit, the overlying Chinle Formation is a continental deposit, and the Glen Canyon Group (partly

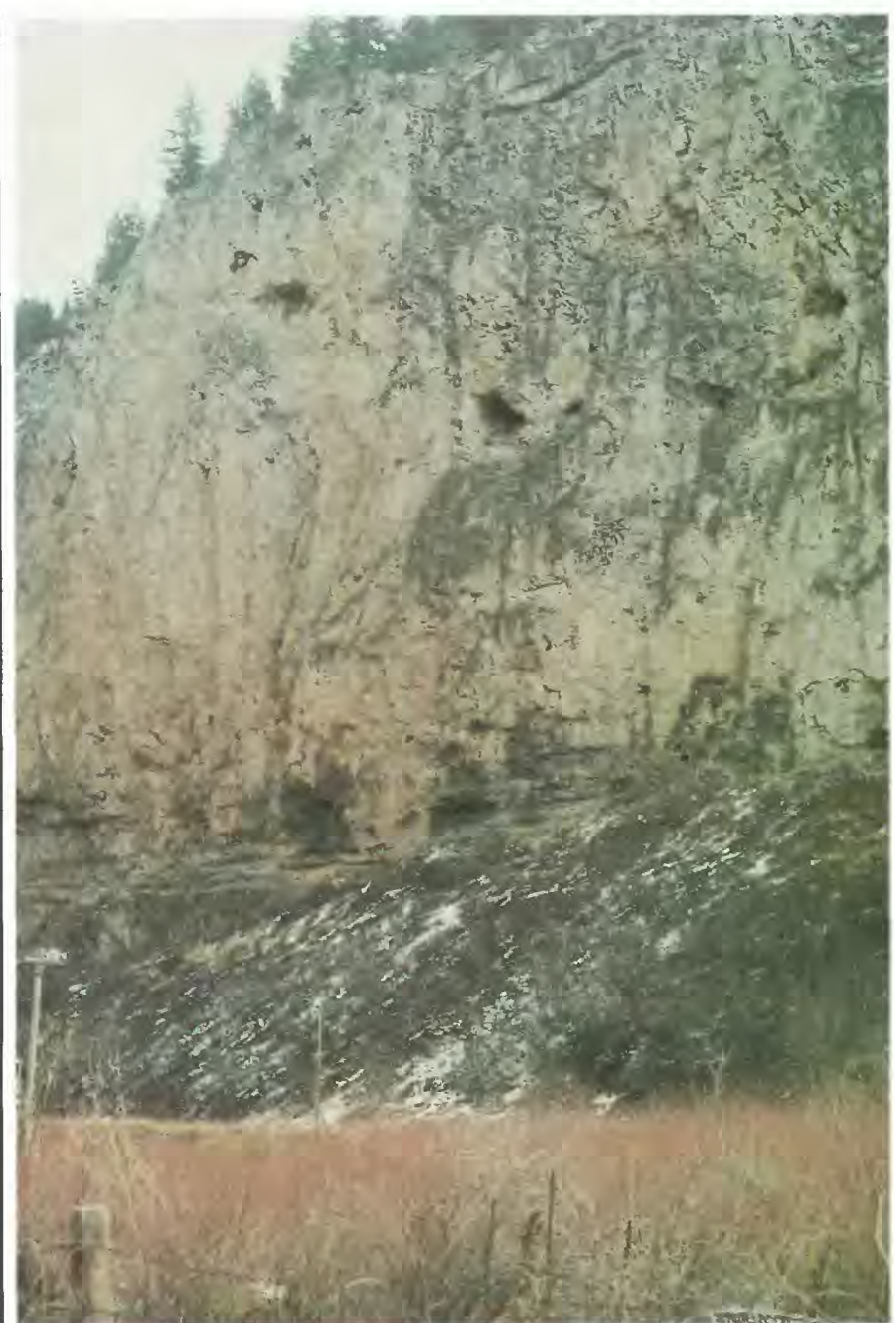

The Leadville Limestone of Mississippian age, which may be an aquifer (fig. 66).

Jurassic) includes two units deposited by wind and separated by stream deposits. Triassic rocks are as thick as 1,500 feet at the northern edge of the basin. The Uncompahgre uplift, south of Grand Junction, was a source area for much of the Triassic sediment.

The Chinle and Glen Canyon form a thick sequence that is mostly sandstone. These formations are aquifers in Utah and other regions, but have not been tested for their aquifer potential in the Piceance basin.

\section{JURASSIC}

Jurassic rocks underlie the entire basin. The marine units in the lower part of the Jurassic thicken westward to possibly more than 300 feet. In the upper part of the Jurassic, the Morrison Formation of continental origin is more than 600 feet thick at its western limit in the structural basin. 


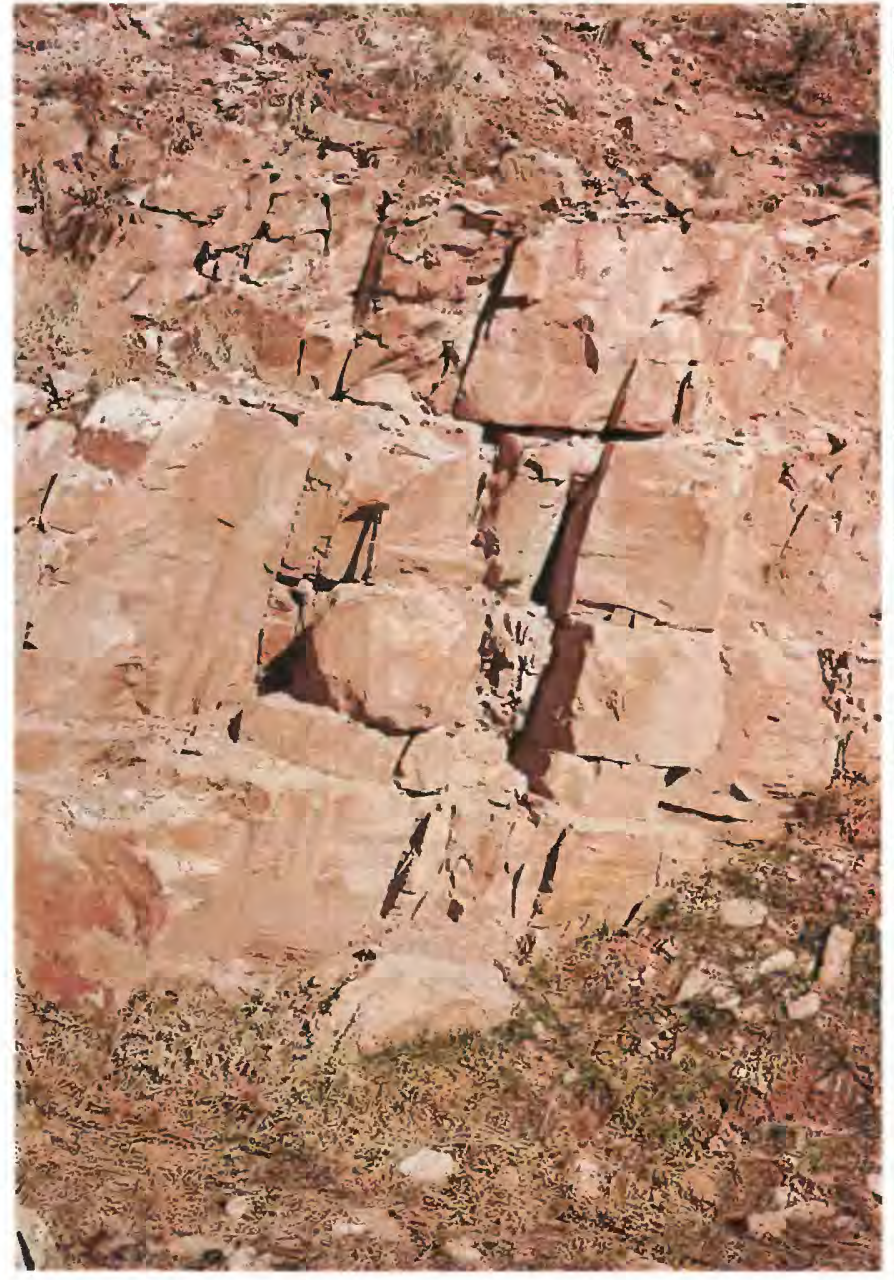

Weber Sandstone of Permian age (fig. 67).

Oil production from the Entrada Sandstone in northwestern Colorado indicates that these rocks are permeable in northwestern Colorado. At Rangely, water produced from the Entrada was injected into the Weber Sandstone for secondary recovery of crude oil.

The Morrison Formation of Jurassic age yields oil and gas in many oil fields of northwestern Colorado; the formation is typically fractured and is known to be an aquifer in other regions.

\section{CRETACEOUS}

Cretaceous rocks underlie the entire basin. The Burro Canyon Formation and Dakota Sandstone at the base are relatively thin in comparison to the Upper Cretaceous rocks
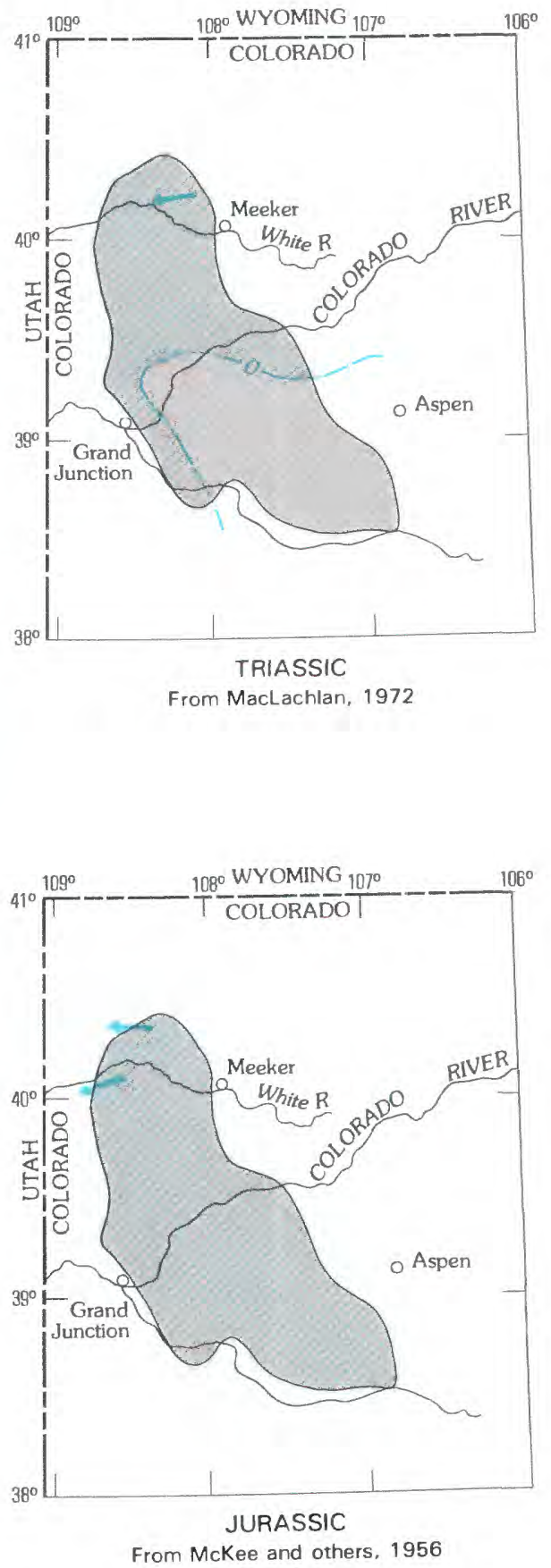

that are more than 10,000 feet thick. Cretaceous rocks are mostly clastic rocks of marine (Mancos Shale) and continental to marine (Burro Canyon Formation and Mesaverde Group) origin. The Dakota may have been deposited in coastal swamp and beach areas. 

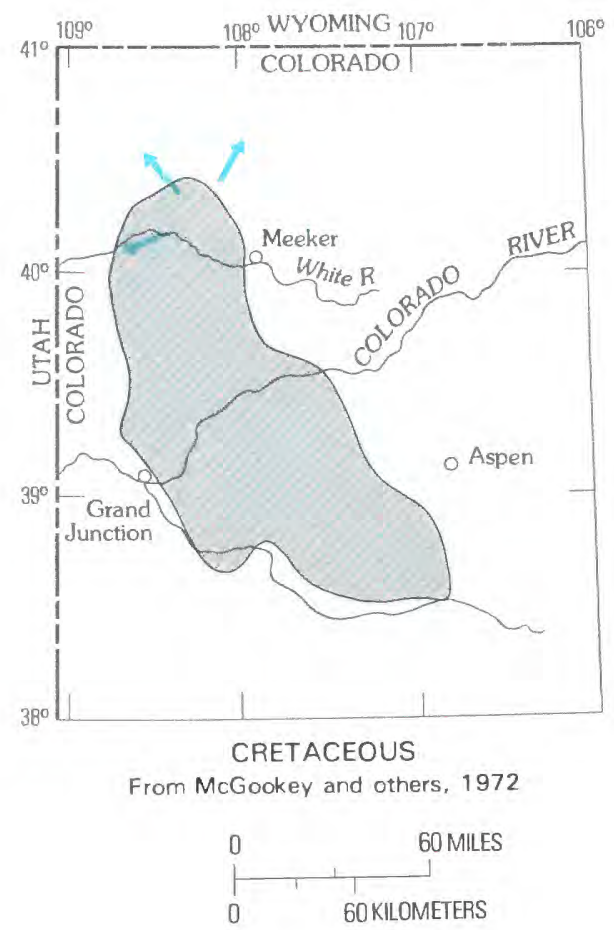

\section{EXPLANATION}

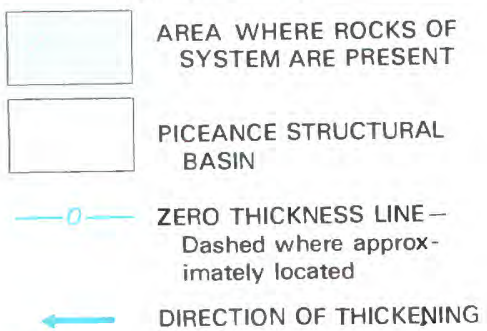

Distribution of Mesozoic rocks under the Piceance structural basin (fig. 68 above and facing page).

Several formations of Cretaceous age are aquifers. Wells yielding water and gas have been completed in the Dakota Sandstone over a large region. Near Douglas Creek, to the west of the Piceance basin, upper sandstone members of the Mancos Shale yield water to wells. Water also is reported in the Mancos Shale in nearby regions. The sandstones of the Mesaverde Group in a coal mine near Meeker are fractured and water bearing. The mine must be pumped continuously to prevent flooding. In general, many sandstones of the Mesaverde Group are locally porous and water bearing. In the Piceance basin, these sandstones may be sufficiently porous and permeable for wastewater injection.

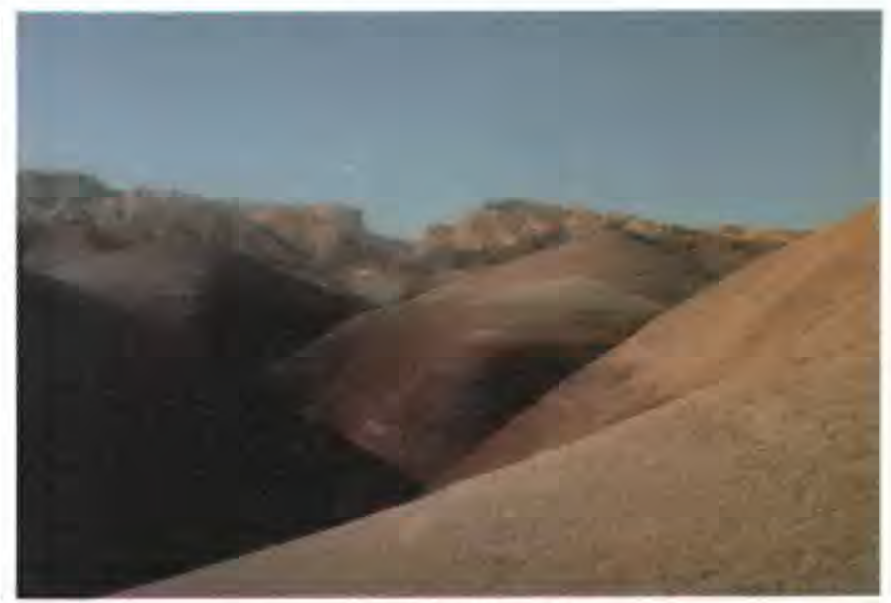

Morrison Formation

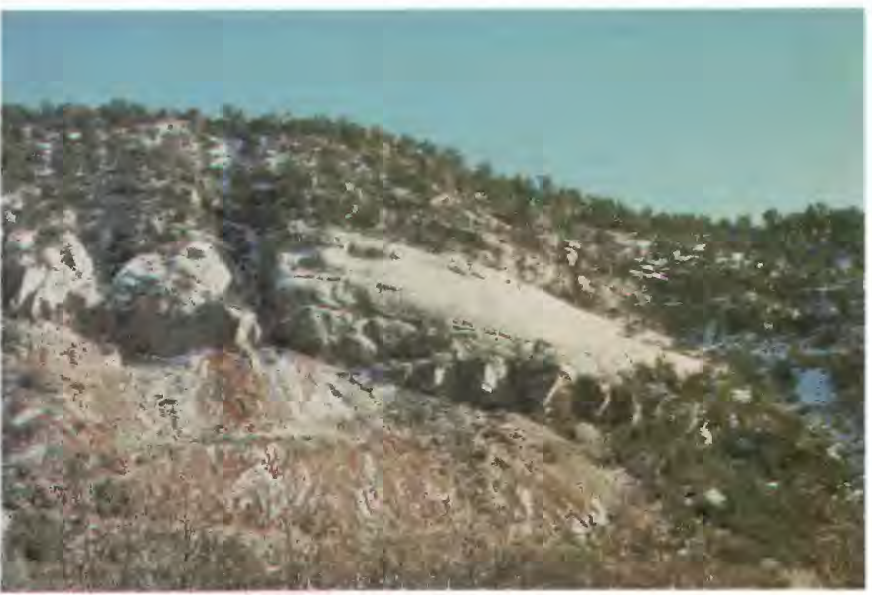

Entrada Sandstone

The Morrison Formation (A) and Entrada Sandstone (B) of Jurassic age, which may be aquifers (fig. 69).

\section{TEST HOLES ARE NEEDED TO EXPLORE FOR DEEP AQUIFERS}

Many formations of Paleozoic and Mesozoic age are fractured, porous, permeable, and capable of yielding appreciable amounts of ground water for oil-shale development. A test hole could be drilled in the Piceance basin through all formations that may be aquifers. A good place for such an exploratory hole is near the White River uplift on the east side of the Piceance basin, where only a few thousand feet of drilling would penetrate the entire sedimentary sequence and reach rocks of Precambrian age. A comparable test hole near the center of the Piceance basin might be 25,000 feet deep and would be prohibitively expensive. 


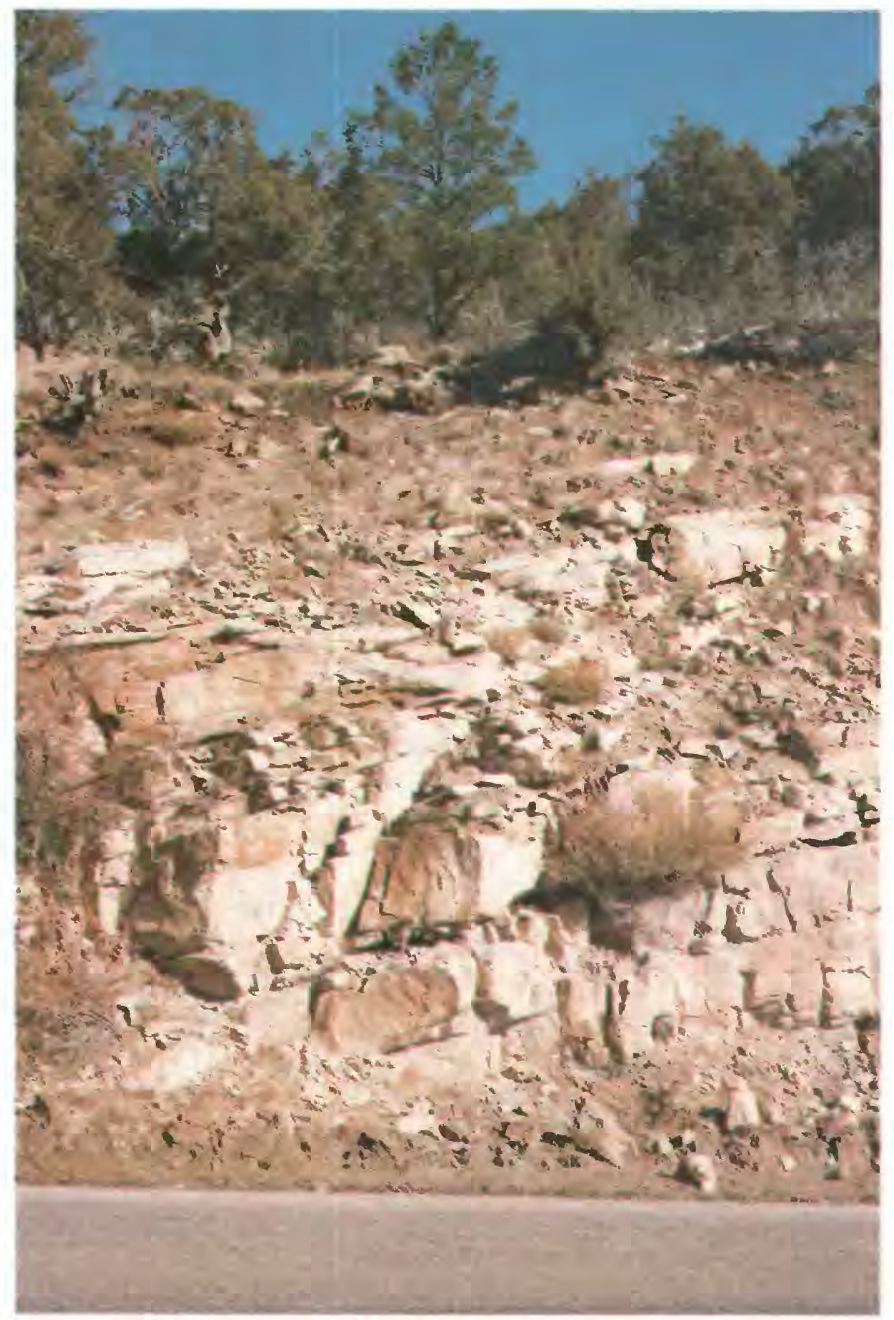

Dakota Sandstone

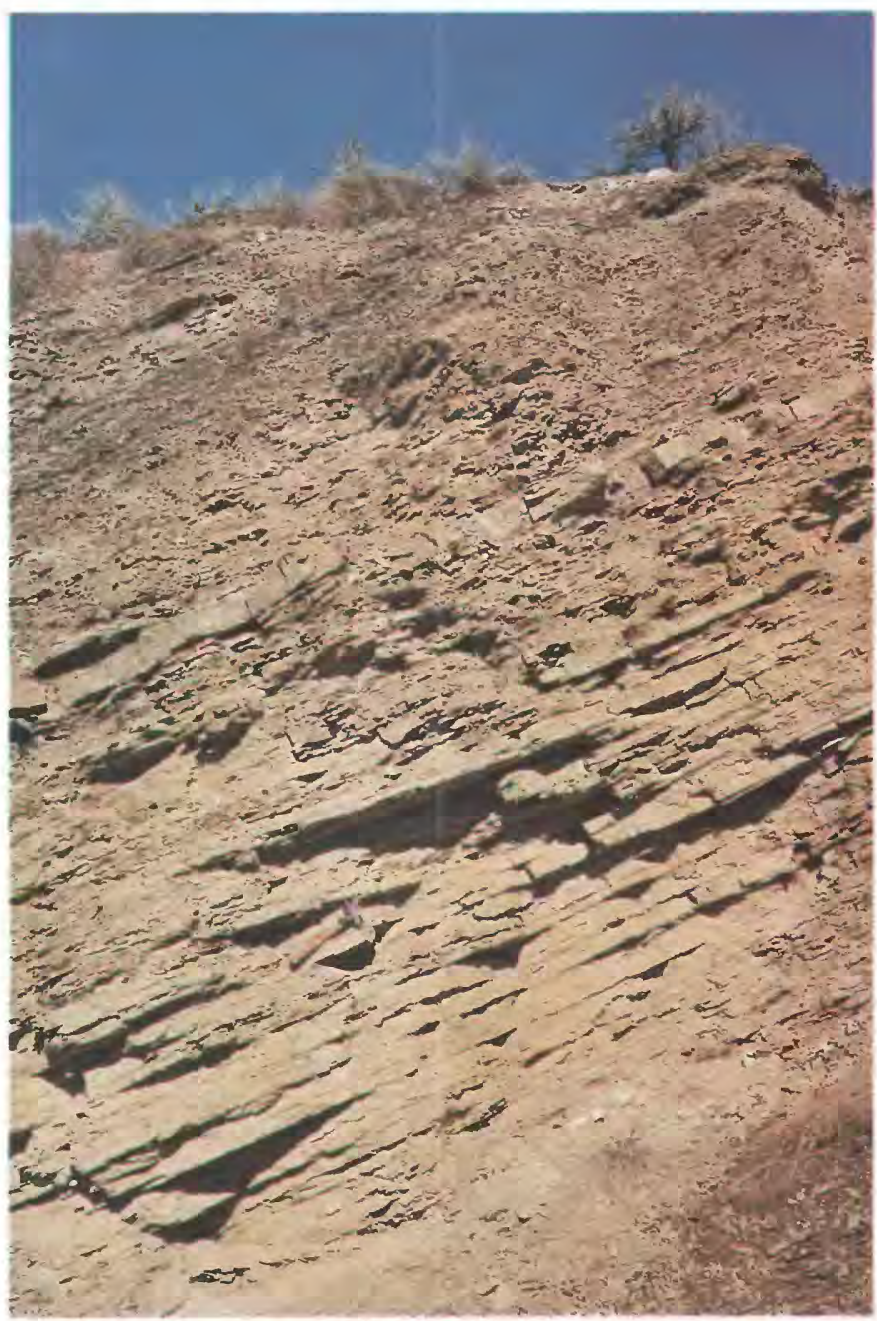

Mancos Shale

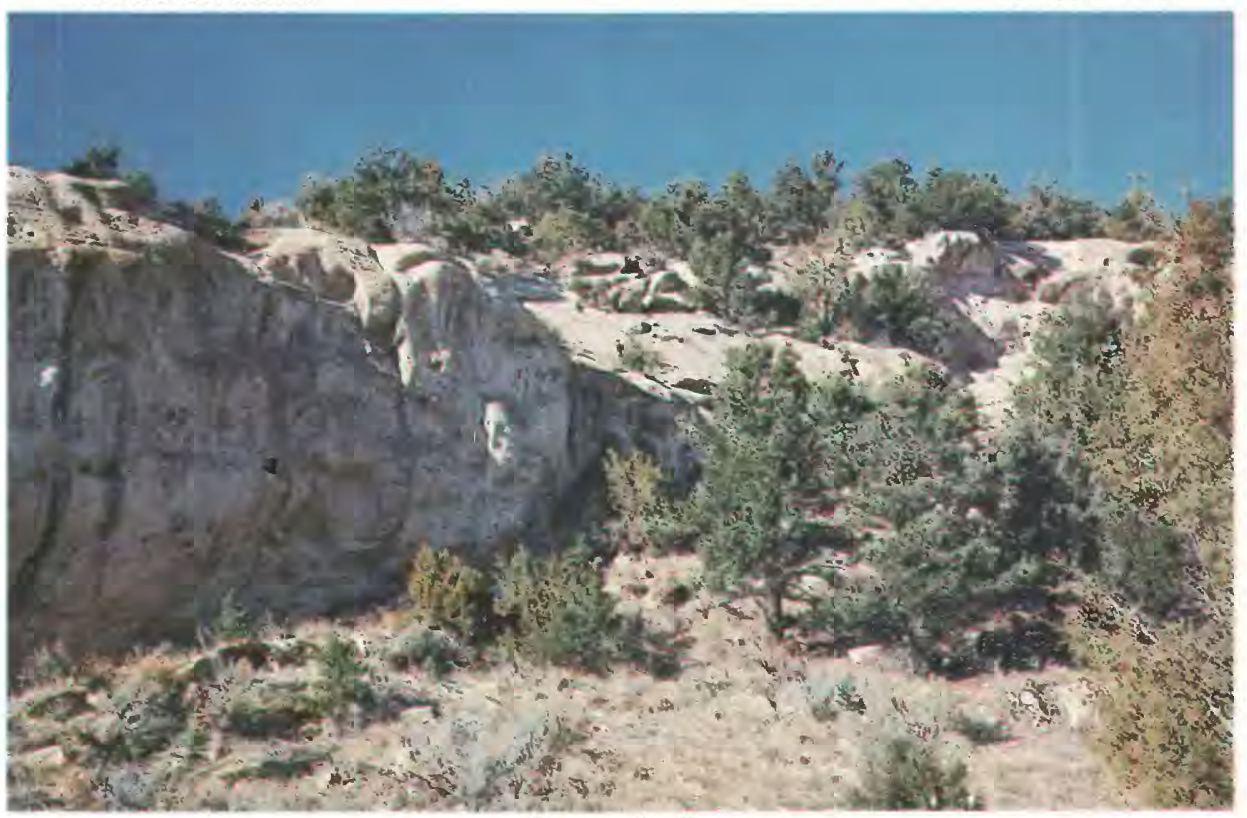

Mesaverde Group

The Dakota Sandstone, Mancos Shale, and Mesaverde Group of Cretaceous age, which may be aquifers (fig. 70). 


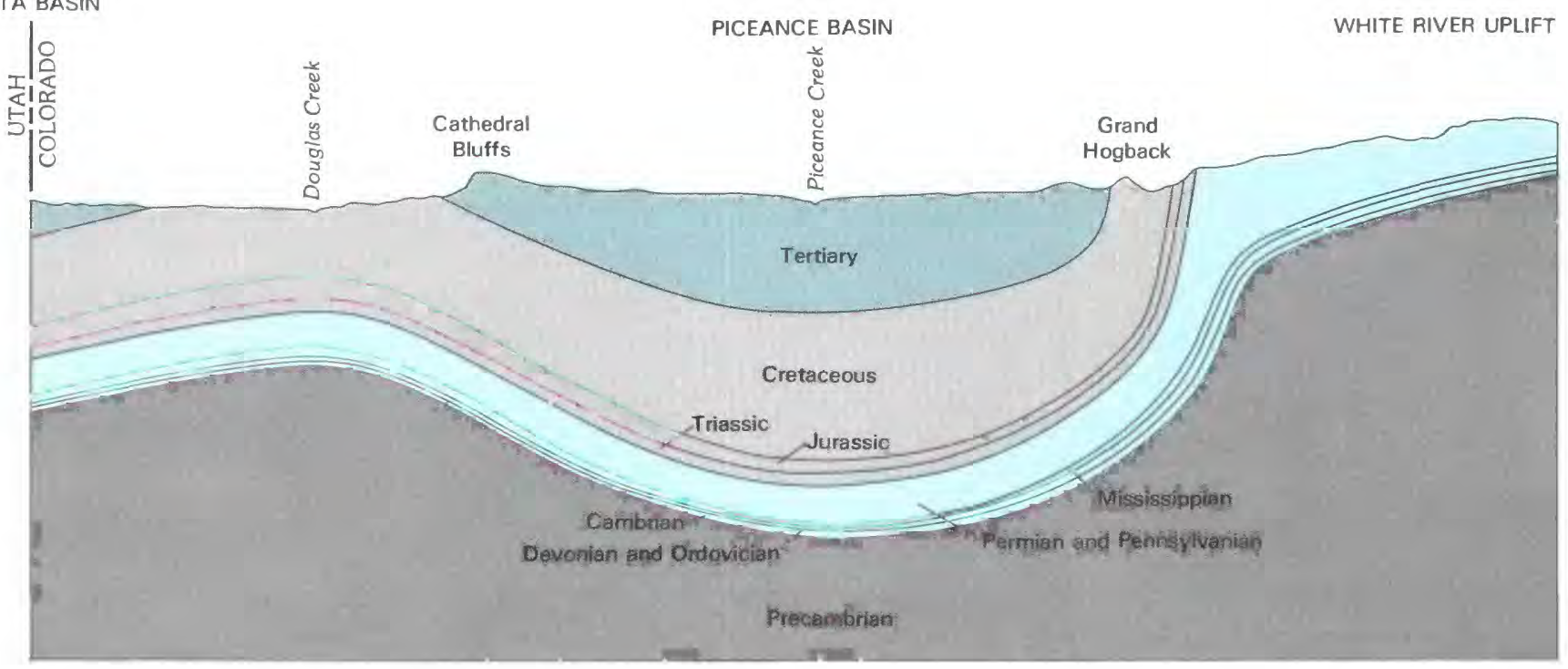

Diagrammatic east-west cross section, northwestern Colorado, showing distribution of rocks for systems of Paleozoic and Mesozoic Era (fig. 71).

\section{REFERENCES}

Baars, D. L., 1972, Devonian System, in Geologic atlas of the Rocky Mountain region, Rocky Mountain Association of Geologists: Denver, A. B. Hirschfeld Press, p. 90-99.

Bass, N. W., and Northrup, S. A., 1963, Geology of Glenwood Springs quadrangle and vicinity, northwestern Colorado: U.S. Geological Survey Bulletin 1142-J, 74 p.

Bryant, Bruce, 1979, Geology of the Aspen 15-minute quadrangle, Pitkin and Gunnison Counties, Colorado: U.S. Geological Survey Professional Paper 1073, 46 p.

Cashion, W. B., compiler, 1973, Geologic and structure map of the Grand Junction quadrangle, Colorado and Utah: U.S. Geological Survey Miscellaneous Investigations Map I-736.

Craig, L. C., compiler, 1972, Mississippian System, in Geologic atlas of the Rocky Mountain region, Rocky Mountain Association of Geologists: Denver, A. B. Hirschfeld Press, p. 100-110.

Donnell, J. R., 1962, Tertiary geology and oil-shale resources of the Piceance Creek basin between the Colorado and White Rivers, northwestern Colorado: U.S. Geological Survey Bulletin 1082-L, p. 835-891.

Foster, N. H., 1972, Ordovician System, in Geologic Atlas of the Rocky Mountain region, Rocky Mountain Association of Geologists: Denver, A. B. Hirschfeld Press, p. 76-85.

Gaskill, D. L., and Godwin, L. H., 1966, Geologic map of the Marble quad rangle, Gunnison and Pitkin Counties, Colorado: U.S. Geological Survey Geologic Quadrangle Map GQ-512.

Hail, W. J., Jr., 1974, Geologic map of the Rough Gulch quadrangle, Rio Blanco and Moffat Counties, Colorado: U.S. Geological Survey Geologic Quadrangle Map GQ-1195.

Hansen, W. R., 1965, Geology of the Flaming Gorge area, Utah-ColoradoWyoming: U.S. Geological Survey Professional Paper 490, 196 p.
Hansen, W. R., and Carrara, P. E., 1980, Geologic map of the Tanks Peak quadrangle, Moffat County, Colorado: U.S. Geological Survey Geologic Quadrangle Map GQ-1534.

Imlay, R. W., 1980, Jurassic paleobiogeography of the conterminous United States in its continental setting: U.S. Geological Survey Professional Paper 1062, $134 \mathrm{p}$.

Johnson, R. C., and May, Fred, 1980, A study of the Cretaceous-Tertiary unconformity in the Piceance Creek basin, Colorado-The underlying Ohio Creek Formation (Upper Cretaceous) redefined as a member of the Hunter Canyon or Mesaverde Formation: U.S. Geological Survey Bulletin 1482-B, 27 p.

Johnson, R. C., May, Fred, Hansley, P. L., Pitman, J. K., and Fouch, T. D., 1980, Petrography, x-ray mineralogy, and palynology of a measured section of the Upper Cretaceous Mesaverde Group in Hunter Canyon, western Colorado: U.S. Geological Survey Oil and Gas Investigations Chart OC-91.

King, P. B., and Beikman, H. M., compilers, 1974, Geologic map of the United States: U.S. Geological Survey, scale 1:2,500,000.

Lochman-Balk, Christina, 1972, Cambrian System, in Geologic Atlas of the Rocky Mountain region, Rocky Mountain Association of Geologists: Denver, A. B. Hirschfeld Press, p. 60-75.

Lohman, S. W., 1965, Geology and artesian water supply, Grand Junction area, Colorado: U.S. Geological Survey Professional Paper 451, $149 \mathrm{p}$.

McGookey, D. P., Haun, J. D., Hale, L. A., Goodell, H. G., McCubbin, D. G., Weimer, R. J., and Wulf, G. R., 1972, Cretaceous System, in Geologic atlas of the Rocky Mountain region, Rocky Mountain Association of Geologists: Denver, A. B. Hirschfeld Press, p. 190-228.

McKee, E. D., and others, 1967, Paleotectonic investigations of the Permian System: U.S. Geological Survey Miscellaneous Geologic Investigations Map I-450. 
1956, Paleotectonic maps of the Jurassic System: U.S. Geological Survey Miscellaneous Geologic Investigations Map I-175.

MacLachlan, M. E., 1972, Triassic System, in Geologic atlas of the Rocky Mountain region, Rocky Mountain Association of Geologists: Denver, A. B. Hirschfeld Press, p. 166-176.

Mallory, W. W., 1972, Regional synthesis of the Pennsylvanian System, in Geologic atlas of the Rocky Mountain region, Rocky Mountain Association of Geologists: Denver, A. B. Hirschfeld Press, p. 111-128.

Murray, F. N., 1966, Stratigraphy and structural geology of the Grand Hogback Monocline, Colorado: Boulder, University of Colorado, Ph. D. thesis, $219 \mathrm{p}$.

Pipiringos, G. N., and Imlay, R. W., 1978, Lithology and subdivisions of the Jurassic Stump Formation in southwestern Idaho and adjoining areas: U.S. Geological Survey Professional Paper 1035-C, $256 \mathrm{p}$.

Pipiringos, G. N., and Rosenlund, G. C., 1977, Geologic map of the White Rock quadrangle, Colorado: U.S. Geological Survey Miscellaneous Field Studies Map MF-837.

Poole, F. G., and Stewart, J. H., 1964, Chinle Formation and Glen Canyon Sandstone in northeastern Utah and northwestern Colorado: U.S. Geological Survey Professional Paper 501-D, p. 30-39.
Ross, R. J., Jr., and Tweto, Ogden, 1980, Lower Paleozoic sediments and tectonics in Colorado: Rocky Mountain Association of Geologists-1980 Symposium, Colorado Geology, p. 47-56.

Rowley, P. D., and Hansen, W. R., 1979, Geologic map of the Plug Hat Rock quadrangle, Moffat County, Colorado: U.S. Geological Survey Geologic Quadrangle Map GQ-1514.

Rowley, P. D., Dyni, J. R., Hansen, W. R., and Pipiringos, G. N., 1979, Geologic map of the Indian Water quadrangle, Moffat County, Colorado: U.S. Geological Survey Geologic Quadrangle Map GQ-1516.

Tweto, Ogden, 1975, Laramide (Late Cretaceous-early Tertiary) orogeny in the southern Rocky Mountains: Geological Society of America Memoir 144, p. 1-44.

Tweto, Ogden, compiler, 1976, Geologic map of the Craig $1^{\circ} \times 2^{\circ}$ quadrangle, northwestern Colorado: U.S. Geological Survey Miscellaneous Investigations Map I-972.

Tweto, Ogden, Moench, R. H., and Reed, J. C., Jr., 1978, Geologic map of the Leadville $1^{\circ} \times 2^{\circ}$ quadrangle, northeastern Colorado: U.S. Geological Survey Miscellaneous Investigations Map I-999.

Spoil piles of retorted shale are the subject of special studies, as described in the following chapter. 


\title{
CHEMICAL EFFECTS AND CONTROL OF LEACHATES FROM OIL-SHALE SPOIL PILES
}

\author{
BY KENNETH G. STOLLENWERK
}

\section{TOXIC SUBSTANCES MAY BE LEACHED FROM SPOIL PILES OF RETORTED OIL SHALE}

Spoil piles resulting from aboveground disposal of retorted oil shale and associated wastes could cause contamination of ground water and surface water in the Piceance basin. Studies have shown that large quantities of substances that are potentially toxic to plants and animals, including humans, may be released to the water that comes in contact with retorted oil shale. One such study shows the results of leaching oil shale that was retorted using two different aboveground processes. Leachate from a sample of recently mined unretorted oil shale was also included in the study for comparison, because significant quantities of crushed unretorted oil shale also may be stored in piles on the land surface.

Dissolved solids, molybdenum, fluoride, and boron are the major inorganic contaminants in leachate from oil shale. High concentrations of dissolved solids interfere with the normal biologic functions of plants and animals. Small quantities of molybdenum, fluoride, and boron are essential for plants and animals; however, larger quantities can be toxic. Leachate from oil shale that has been retorted using various processes, as well as leachate from unretorted oil shale, would have to be substantially diluted in order to meet the recommended criteria of the U.S. Environmental Protection Agency for potable water and for irrigation water. The limits for the National Pollutant Discharge Elimination System (NPDES) specify the maximum allowable daily discharge for a contaminant from any single source. Any leachate or treated leachate that is discharged to streams will have to meet NPDES standards. Several factors affect the type and quantity of constituents leached from retorted oil shale-the chemical and mineralogical composition of the unretorted shale and of the retorted shale waste, the particle-size distribution of the fresh and retorted oil shale, the type of retorting process used, and the conditions under which leaching occurs. In addition, several other waste products, such as industrial wastewater and other solid-waste material, may be disposed with the retorted oil shale, and these other products may modify the composition of the leachate.
The aboveground disposal of retorted oil shale and associated wastes is described in the chapter "Development of the oil shale and associated minerals."

\section{LEACHATE FROM SPOIL PILES MAY FLOW INTO AQUIFERS AND STREAMS}

The impact of leachate from spoil piles on the quality of ground and surface water in the Piceance basin ultimately will depend upon the quantity of leachate produced and location of spoil piles. Natural recharge to the bedrock aquifers results from snowmelt at the higher altitudes in the basin. Placement of spoil piles in a recharge area also could permit recharge on the spoil piles themselves. The resulting leachate draining from the spoil piles may migrate into natural flow systems in the soil, alluvium, and bedrock, where some of the potentially toxic elements may be removed. As the leachate migrates, it will be subject to chemical and physical reactions such as dispersion, diffusion, filtration, ion-exchange reactions, absorption, chemical precipitation, and biochemical degradation, which may change its quality. Eventually the leachate could become part of the regional flow system and might discharge to springs and streams. Placement of spoil piles in areas of natural discharge is undesirable also because water discharging from springs could saturate the sides and bottom of spoil piles, causing leaching and instability.

The quality of surface and ground water can be impacted by surface runoff over or through spoil piles. To minimize or prevent this, diversion channels can be constructed to direct surface runoff around the spoil piles. The diversion system will have to be maintained to prevent reestablishment of natural drainage patterns.

Sources of contaminants other than leachates also could lead to a deterioration in the quality of ground and surface water. Wastewater from the retorting process could leak through the sides and bottoms of holding ponds before it is treated. Dams will be constructed downstream from the spoil piles in order to collect surface runoff from the piles, and other ponds may be constructed to store water pumped during mine drainage. Infiltration of water from these retention ponds could be a source of contamination. 
EXPLANATION
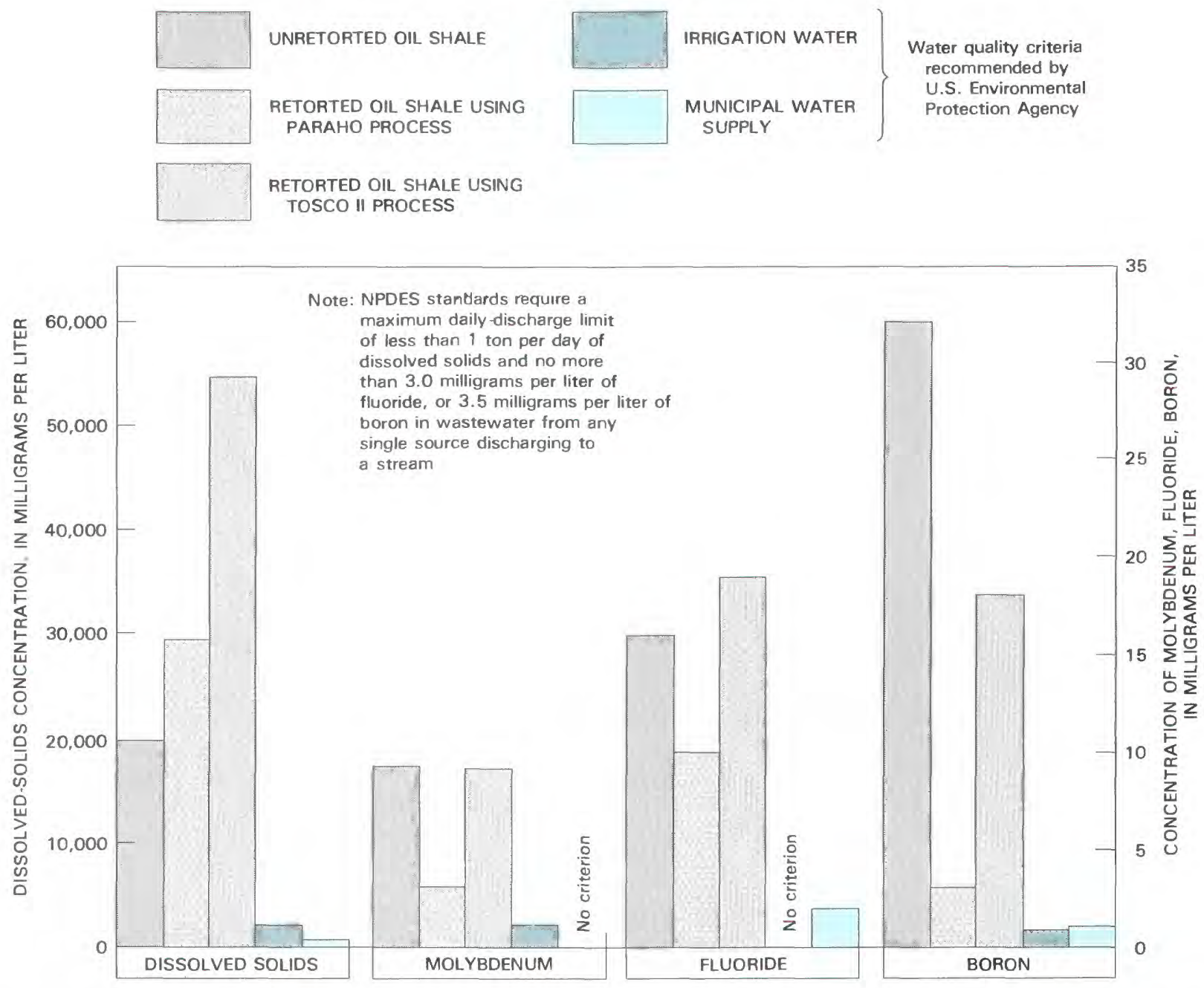

Concentrations of dissolved solids, molybdenum, fluoride, and boron in leachate from three different types of oil shale (fig. 72).

\section{CONTROL TECHNOLOGY CAN REDUCE CONTAMINATION FROM SPOIL PILES}

Several procedures can minimize the adverse effects of the contaminants from spoil piles:

1. Locate spoil piles in small watersheds that have little precipitation, in order to minimize the quantity of leachate generated.

2. Select a site that is distant from springs so that discharge from springs will not saturate the bottom and sides of the spoil piles.
3. Grade the spoil-pile surfaces to minimize ponding and infiltration.

4. Establish a vegetative cover on the surface of the spoil piles to transpire some of the water that infiltrates the surface.

5. Induce controlled leaching of the spoil piles in order to decrease the concentration of dissolved solids in any future leachate. The induced leachate would have to be stored, treated, and disposed properly.

6. Install liners beneath wastewater-holding ponds in order to induce or prevent infiltration. 


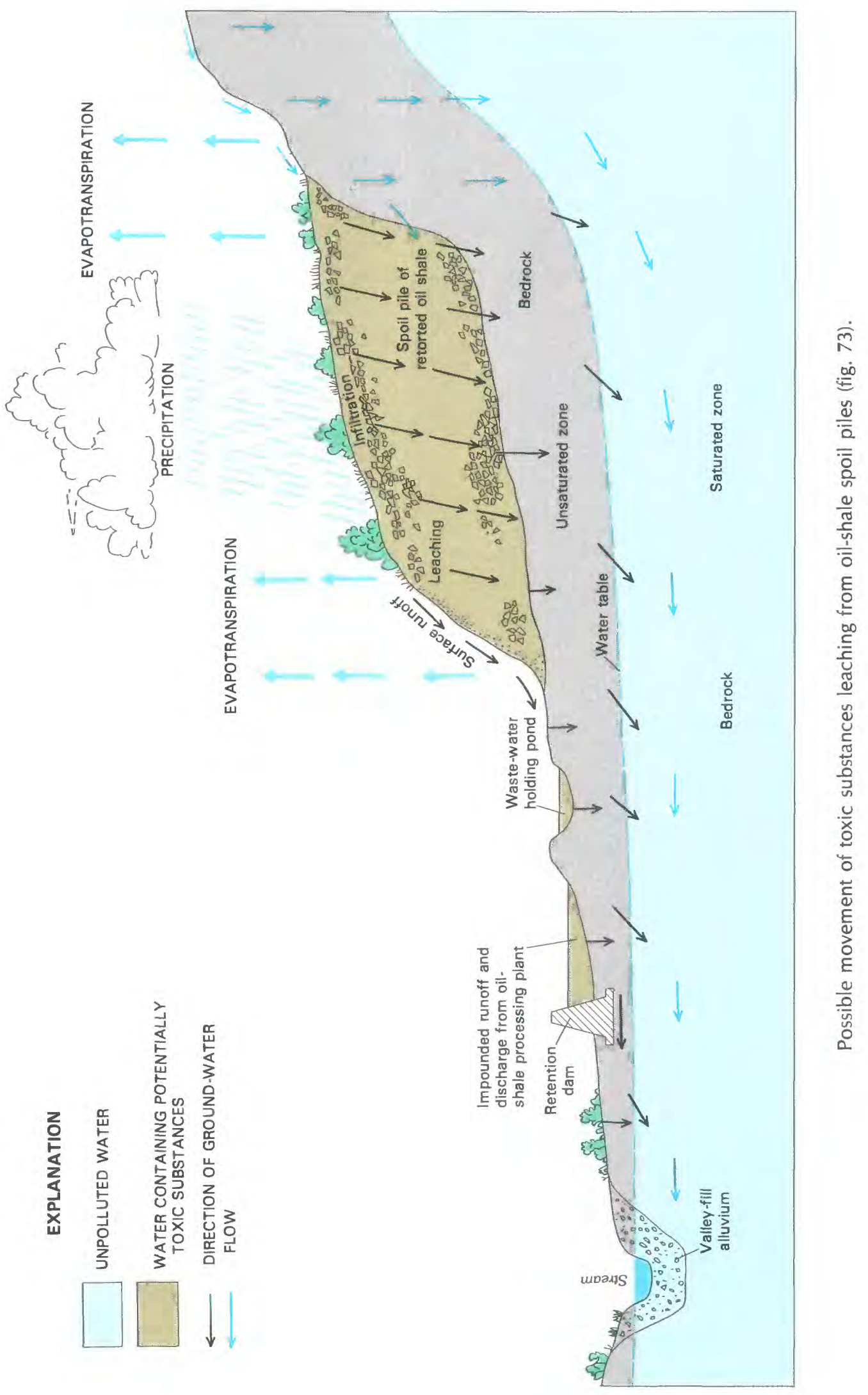


Mitigation measures may prevent significant quantities of leachate from moving into the ground- and surface-water systems during the lifetime of a retorting operation. However, leachate may continue to infiltrate the land surface for hundreds of years before contaminants are reduced to levels harmless to plants and animals.

\section{REFERENCES}

Bates, E. R., and Thoem, T. L., 1979, Pollution control guidance for oil shale development:. U.S. Environmental Protection Agency, Revised draft report, p. 370.
Stollenwerk, K. G., and Runnells, D. D., 1981, Composition of leachate from surface-retorted and unretorted oil shale:. Environmental Science and Technology, American Chemical Society, v. 15, no. 11, p. 1340-1346.

U.S. Environmental Protection Agency, 1976, Quality criteria for water: U.S. Environmental Protection Agency, Washington, D.C., 256 p.

In situ retorts also may affect water quality, as the following discussion indicates. 


\title{
CHEMICAL EFFECTS AND CONTROL OF WASTES FROM IN SITU RETORTS
}

\author{
BY JERRY A. LEENHEER
}

\section{WATER FROM IN SITU RETORTS MAY AFFECT WATER QUALITY}

Although more retorted shale is commonly stored on the land surface from aboveground than from in situ processes, the treatment and disposal of solid, liquid, and gaseous wastes can be controlled better using aboveground processes. Wastes produced by in situ processes cannot be controlled as easily because they remain underground where they are mostly inaccessible. The processing of oil shale using in situ retorts is discussed in the chapter "Development of the oil shale and associated minerals."

\section{WASTES PRODUCED BY MODIFIED IN SITU RETORTS ARE NOT COMPLETELY KNOWN}

Modified in situ retorts are planned on tract C-b in the Piceance basin in part because of concerns with resource recovery, costs of mining, and disposal of retorted shale. With the modified in situ process, about 20 to 40 percent of the oil-shale ore is processed and disposed at the land surface; the remainder is left underground for in situ extraction of shale oil. Little is known about the quantities and properties of, and ultimately, the wastes produced by in situ retorting of oil shale. Therefore, considerable research is being performed to determine how wastes are produced during the construction, during the burning, and after the abandonment of in situ retorts, and to document the effects of wastes on water quality.

Potential sources of wastewater include:

1. Retort water generated during oil-shale retorting,

2. Water produced during mine drainage,

3. Leachate from unretorted and from processed oil shale,

4. Wastewater from air emission-control systems,

5. Cooling water,

6. Water flushed from boilers,

7. Sanitary wastewater.

The amounts of water from each source change during retort construction, oil-shale processing, and after retorts are abandoned.
The two most important wastewater sources are minedrainage water, which constitutes the largest volume of wastewater, and retort water, which may contain the largest amounts of dissolved solids and potential contaminants. Most of the mine-drainage water ultimately may be used as the water supply for aboveground retorts, shale-oil upgrading facilities, and moistening of retorted shale. Initially, minedrainage water will be disposed of by injection underground, application to the land surface, or discharge into surface streams. Retort water is a by-product of the combustion of hydrocarbons, the dehydration of oil-shale minerals by in situ processes, and the flow of ground water into retorts. Most retort water is produced as an emulsion in shale oil and must be physically separated from the oil. A smaller amount of water condenses from retort vapors. Only 5 to 20 percent of the liquid product of an aboveground retort is retort water, but approximately equivalent volumes of retort water and shale oil are produced from in situ retorts.

Retort waters have high concentrations of ammonia that can be recovered during water treatment and used to manufacture fertilizers. Retort waters also have high concentrations of sulfur and organic compounds, which can be detrimental to the environment. Although smaller volumes of aboveground retort waters are produced compared to in situ retort waters, the dissolved-solids concentration is higher in aboveground retort waters. Therefore the total volume of dissolved solids released by both types of retorting is about equal.

\section{SOURCES AND TYPES OF WASTEWATER DEPEND ON THE STAGE OF MODIFIED IN SITU RETORTING}

The sources and volumes of wastewater from the modified in situ retorts change as construction and retorting proceed. During construction of the retort, most of the wastewater is mine drainage. Mine water may become more oxidizing during ponding, and treatment may be required prior to injection or disposal to streams. Leaching of contaminants by rainfall and snowmelt percolating through the unretorted shale in storage piles also may contribute a minor amount of wastewater. 


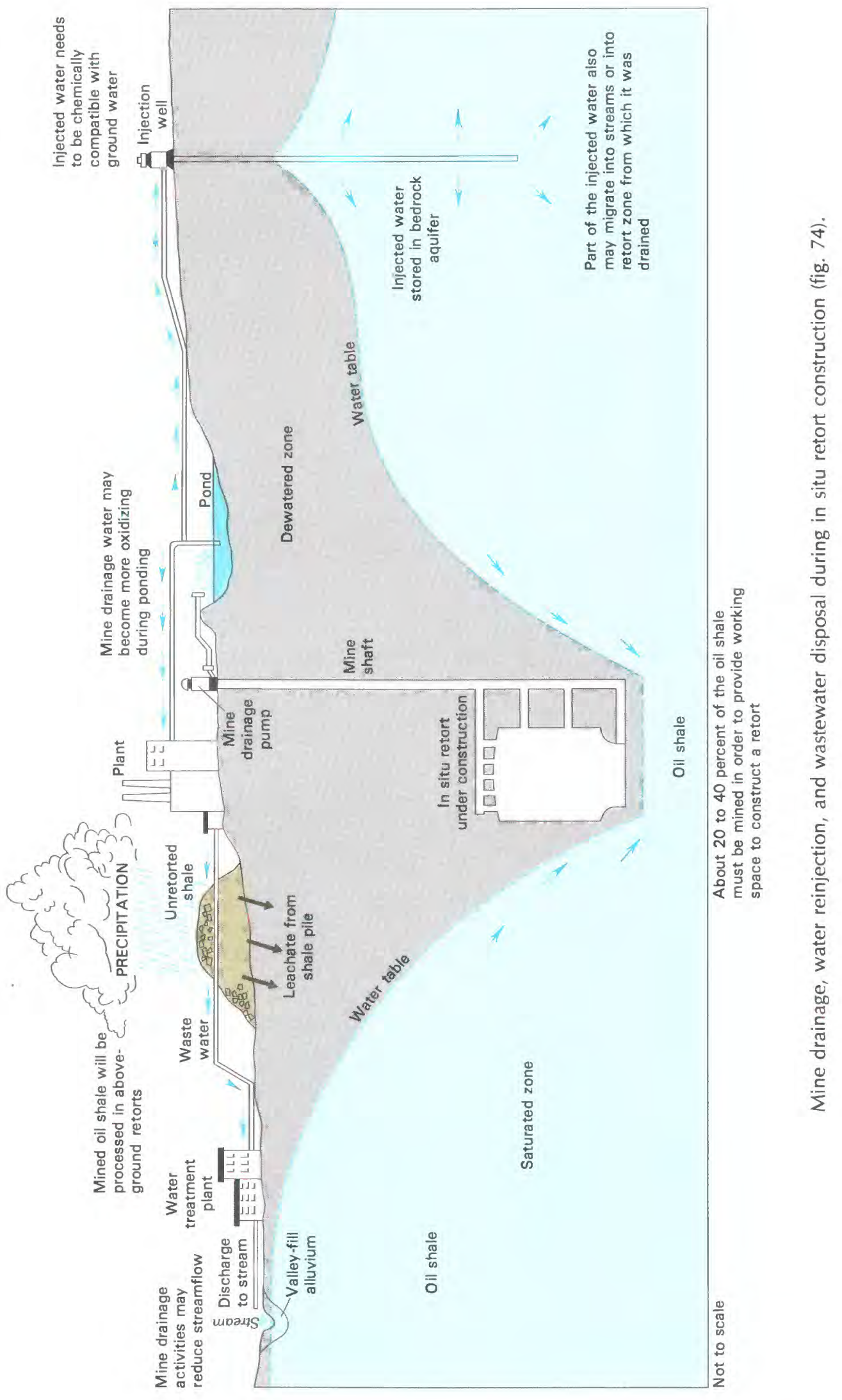




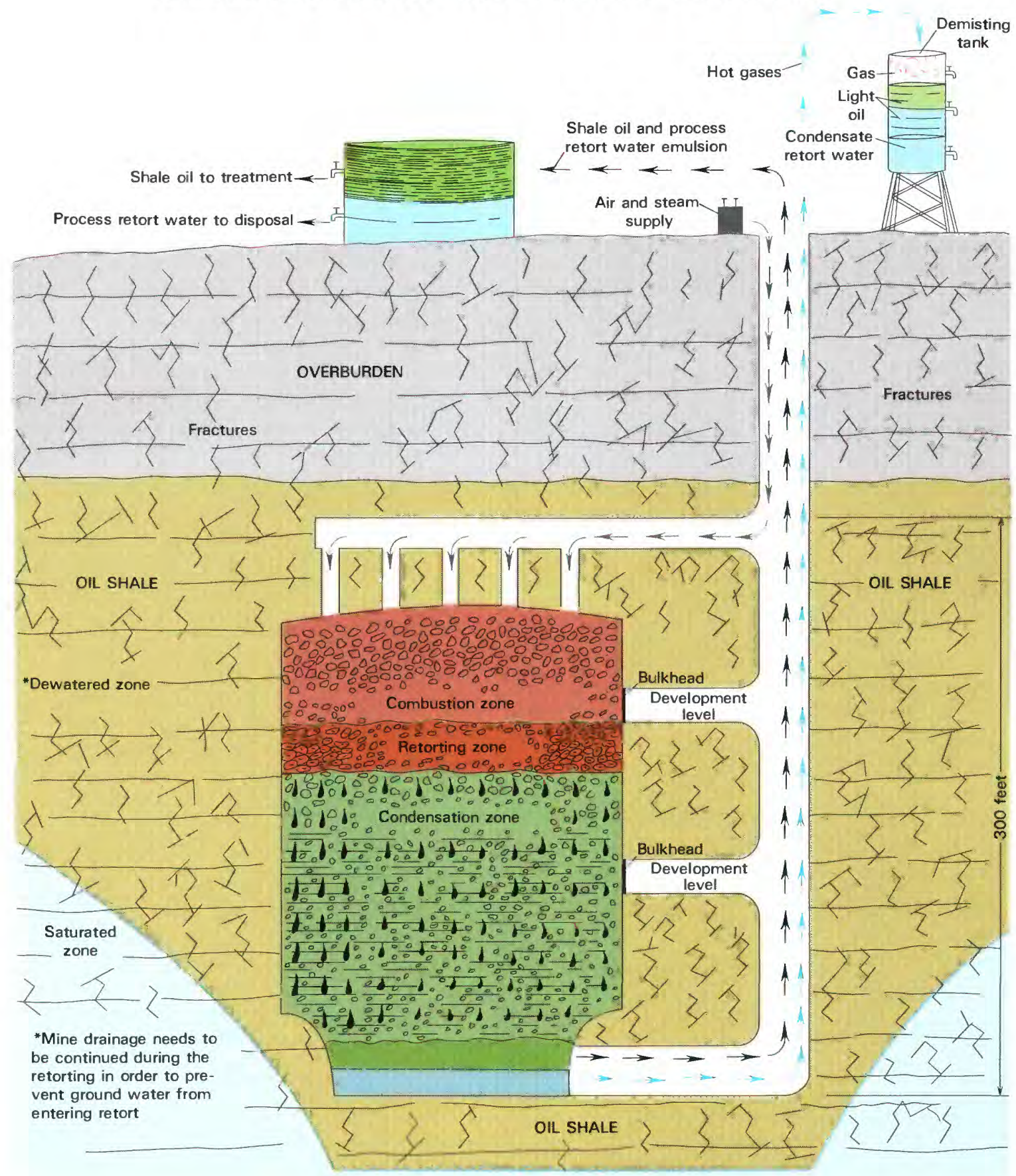

Active modified in situ retort (fig. 75). 


\section{EXPLANATION}

$\lessdot$ GROUND-WATER MOVEMENT

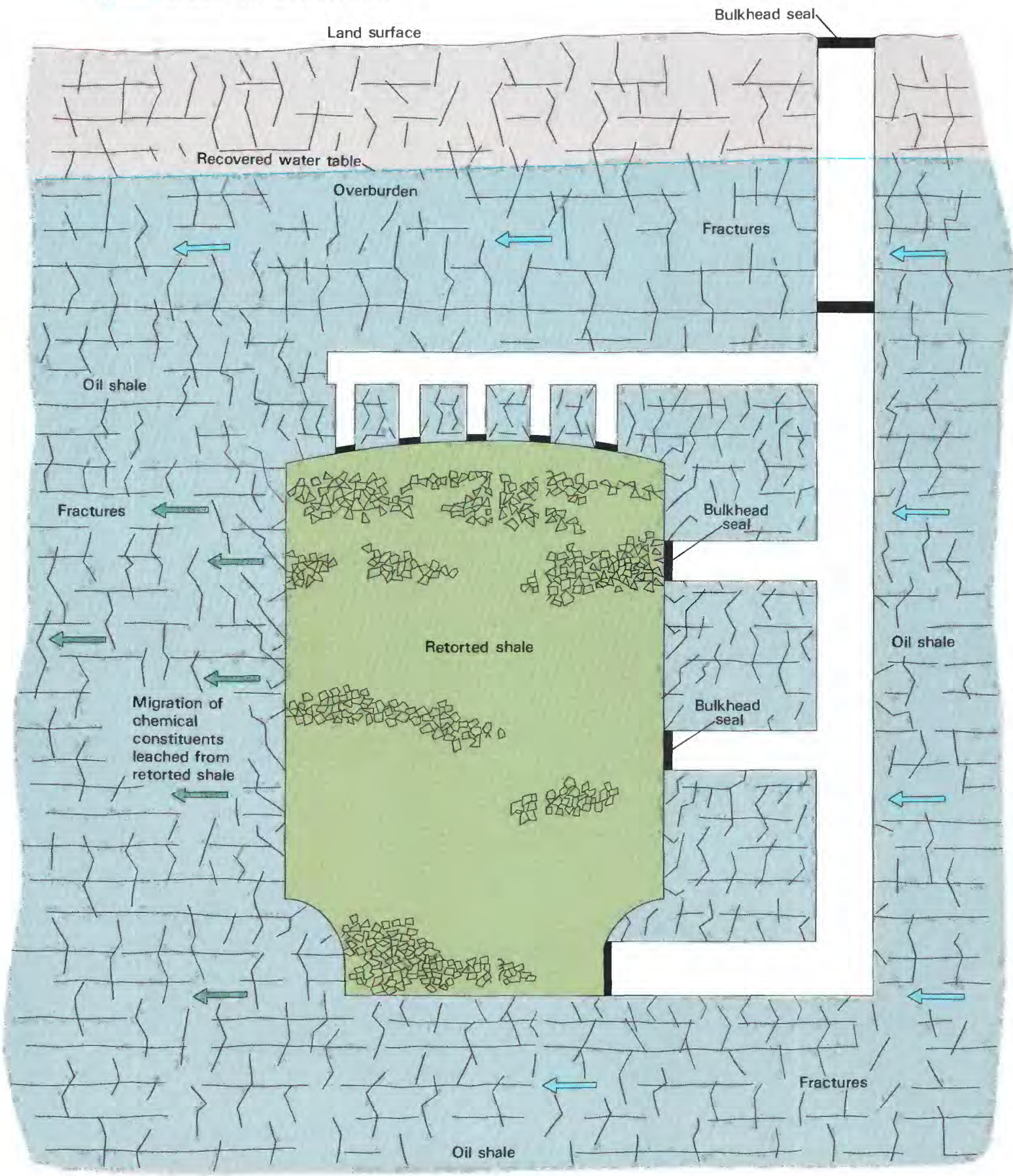

In situ retort after abandonment (fig. 76). 
Retort water is produced during operation of the in situ retort. Retort water recovered with the shale oil and gas probably will need extensive treatment before disposal or reuse, but some retort water, gases, and shale oil may migrate through small fractures. The effect of these unrecovered liquid and gaseous wastes on the ground-water quality has not been determined.

When the burned modified in situ retorts are abandoned and mine-drainage operations cease, the retort will flood with ground water as it cools. As the regional ground-water flow is reestablished, the retorted shale will be leached by ground water. The physical stability of the saturated shale and the fate of solutes leached from the shale are two concerns about abandonment of modified in situ retorts.

\section{CONTROL TECHNOLOGY CAN DECREASE CONTAMINATION FROM IN SITU RETORTS}

Technology will be important to control leachate from in situ retorts. Hundreds of in situ retorts could contaminate ground and surface water basin wide for hundreds of years. Several techniques have been proposed to minimize the adverse effects of any contaminants from in situ retorts:

1. Maintain operating pressures in the active in situ retorts in the unsaturated zone at less than surrounding air pressures, using controlled mine ventilation. The lower pressure should help to contain gaseous and liquid wastes within the retort.

2. Inject grout into the retort zone before retort abandonment in order to prevent the infiltration of and leaching by ground water.

3. Treat wastewater before discharging it into streams.

4. Store piles of mined, unretorted oil shale in areas where problems of erosion and leaching are less likely to develop.

\section{REFERENCES}

Jackson, L. P., Poulson, R. E., Spedding, T. J., Phillips, T. E., and Jensen, H. B., 1975, Characteristics and possible roles of various waters significant to in situ oil shale processing:. Proceedings of the Environmental Oil Shale Symposium, Quarterly of the Colorado School of Mines, v. 70, no. 4, p. 105-134.

Stuber, H. A., and Leenheer, J. A., 1978, Fractionation of organic solutes in oil shale retort waters for sorption studies on spent shale:. Division of Fuel Chemistry, American Chemical Society, v. 23, no. 2, p. 165-174.

Gaseous and particulate emissions from oil-shale retorts to the atmosphere may change the quality of precipitation and lake water, as the following section indicates. 



\title{
EFFECTS OF EMISSIONS FROM OIL-SHALE RETORTS TO THE ATMOSPHERE
}

\author{
BY JOHN T. TURK
}

Aboveground retorts produce emissions that discharge to the atmosphere and may alter the chemical characteristics of precipitation. In the Northeast, acid rain has resulted partlly from similar emissions from coal-burning powerplants. The altered precipitation may affect the water quality in lakes, impair the aquatic environment, and increase the general corrosiveness of water suppies in the drainage basin.

\section{OIL-SHALE RETORTING EMITS CONTAMINANTS TO THE ATMOSPHERE}

The retorting of oil shale releases gases and particles from the retorted material to the atmosphere. The components released include water and the products of oxidation or reduction reactions at high temperatures, such as:

1. Low molecular weight organic compounds;

2. Volatile elements, such as mercury and arsenic;

3. Ammonia; and

4. Oxides of nitrogen and sulfur.

The amounts of many components that may be released are difficult to predict; however, permissible emission concentrations for sulfur dioxide and the nitrogen oxides have been established by the U.S. Environmental Protection Agency for one commercial operation. If the emissions currently allowed for an oil-shale retort that produces 47,000 barrels of shale oil per day are extrapolated for greater production, oil-shale retorting could become a major source of acidic gases such as sulfur dioxide and nitrogen oxides. The projected emission concentrations for oil-shale retorting are compared with those concentrations produced by modern 800-megawatt coal-burning powerplants of the type operated at Craig, Colo.

\section{THE REGIONAL QUALITY OF PRECIPITATION CAN BE MONITORED}

Emissions to the atmosphere from oil-shale retorts may produce changes in the chemistry of snow and rain downwind from the sources of the emissions. To document the geographical extent as well as the magnitude of chemical alteration, the quality of precipitation upwind and downwind from the potential sources of emissions can be monitored. The monitoring is needed for three main reasons:

1. To detect changes,

2. To verify the effectiveness of controls, and

3. To allow early intervention if a hazardous situation develops.

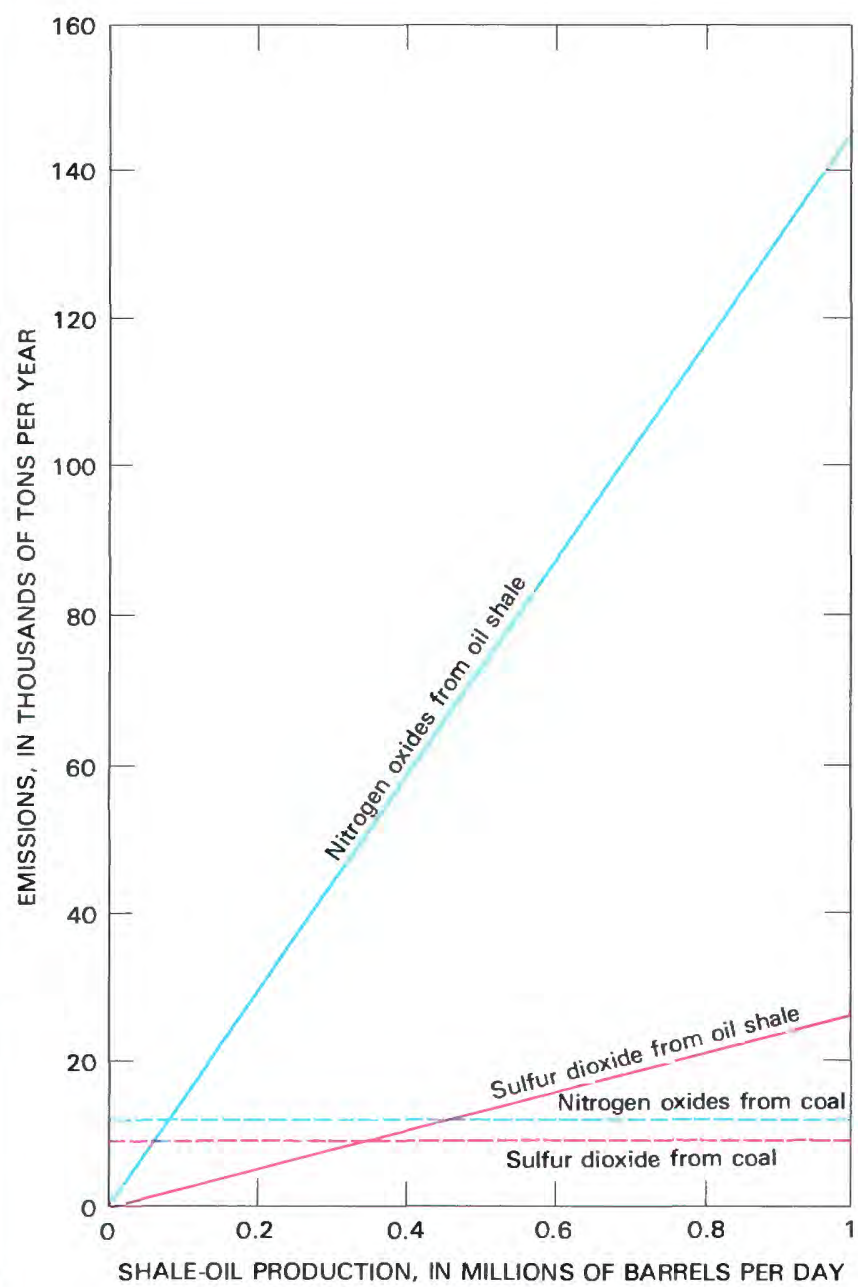

Comparison of projected emissions from oil-shale retorting to measured emissions from coal-fired powerplants in northwest Colorado (fig. 77). 
To separate the effects of oil-shale development from those of other sources of emissions (for example, coalburning powerplants), many monitoring stations will be needed. The predominant wind directions near the site of oil-shale development and near existing coal-burning powerplants in the region are known. Monitoring stations should be located not only on the margins of the region of concern, but also between sources that may interact to affect precipitation quality. Areas that may be affected, such as the Flat Tops and Mount Zirkel Wilderness Areas, also should be monitored.

\section{CHEMICAL CHANGES IN PRECIPITATION MAY ACIDIFY SOME LAKES}

Atmospheric emissions are carried by winds and deposited by precipitation and dry fallout on a variety of downwind watersheds. Acidity is produced by the reaction of sulfur dioxide, nitrogen oxides, and water in the atmosphere. The greatest effect of acidic deposition is likely to be in watersheds where the bedrock and soil are relatively unreactive and, thus, unable to neutralize the acidity. The ability of a hydrologic system to neutralize acidity depends on its

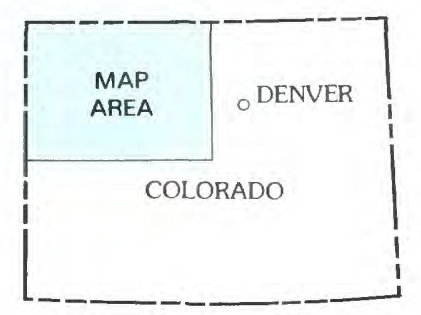

Wind rose lines radiate toward direction from which wind blows. Line length is proportional to wind strength

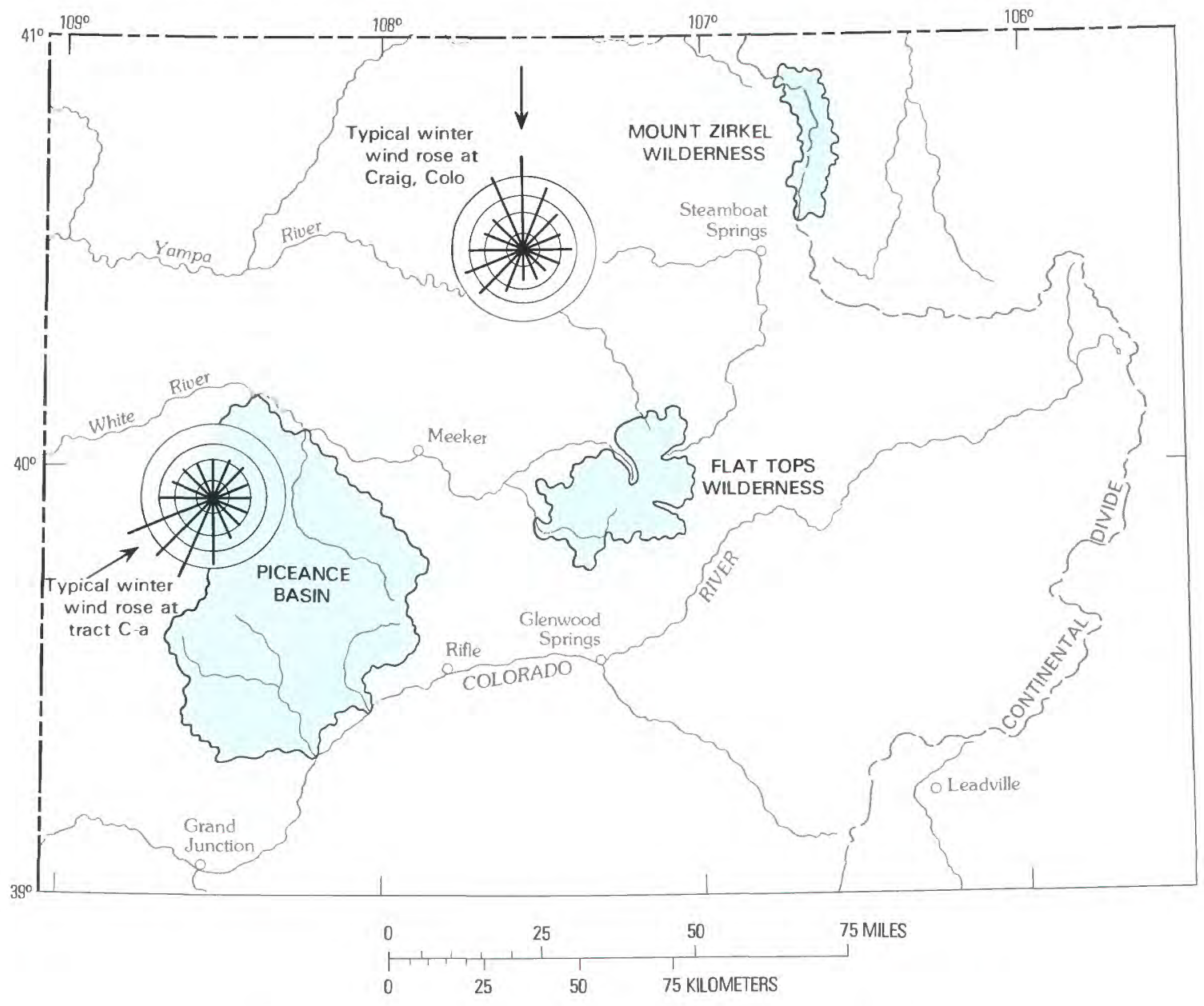

Predominant wind directions in northwestern Colorado (fig. 78). 
alkalinity and can be determined from a plot of $\mathrm{pH}$ versus the amount of a standard acid added to a given volume of water.

For example, the abilities of two lakes in the Flat Tops Wilderness Area (Island and Marvine Lakes) to neutralize added acid are different. Although water from lower Marvine Lake maintains a $\mathrm{pH}$ greater than 5.5 for a relatively large addition of acid, the $\mathrm{pH}$ of water from the upper Island Lake decreases rapidly with only small additions of acid. The shape of the titration curve for upper Island Lake approximates the titration of pure water containing no alkalinity.

A network to monitor changes in lake chemistry and in biology caused by acidification of the lake needs to include primarily lakes with low alkalinity (for example, upper Island Lake). This lake and similar lakes with low alkalinity will be affected long before the more alkaline lakes of an area. At $\mathrm{pH}$ values lower than about 5.5, fish will be harmed to some extent. At $\mathrm{pH}$ values lower than about 4.5, most fish are unable to survive. Titration curves such as these are good relative measures of the overall chemical and biological sensitivity of lake systems to acidification.

\section{LAKES SENSITIVE TO ACIDIFICATION MAY HAVE COMMON CHARACTERISTICS}

Lakes that are most likely to be affected by acidification (that is, the least alkaline lakes) have some common characteristics. For example, the relation between alkalinity and altitude for 15 lakes of the Flat Tops Wilderness Area shows that the most sensitive lakes are located at the highest altitudes. Altitude determines many basin characteristics in the vicinity of potential oil-shale development. Bedrock type, amount of tree cover, snowpack accumulation, precipitation volume, and timing of snowmelt are examples.

Many of these watershed characteristics are related to altitude in such a way as to maximize contaminant loading to the lakes that are least capable of neutralizing aciditythe high-altitude lakes. The least reactive bedrock types, the greatest rate of runoff per unit area of watershed, and the greatest deposition of precipitation and contaminants are associated with the highest altitudes. Thus, the high-altitude lakes are even more susceptible to the effects of acidification than their low alkalinity values would indicate.

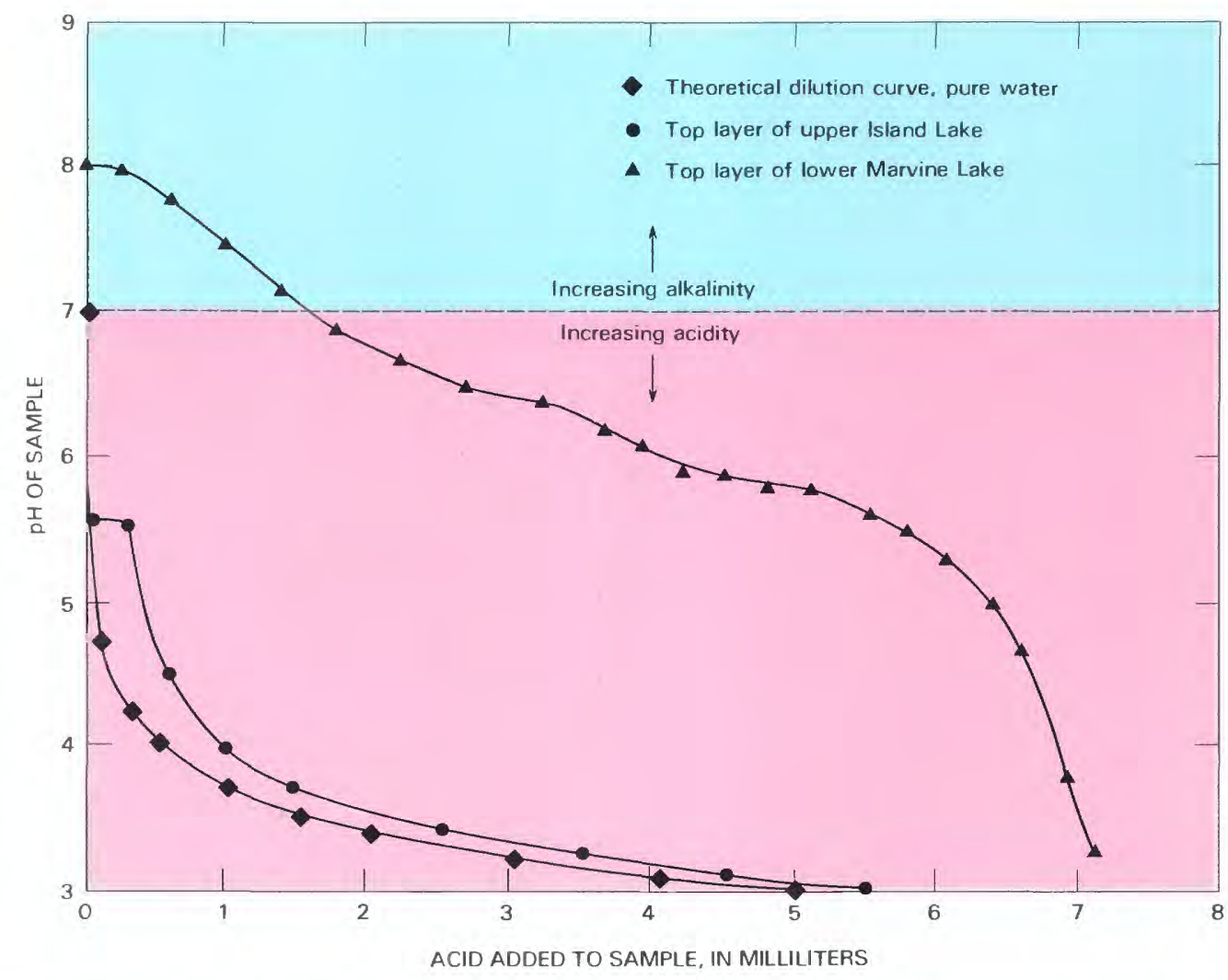

Titration curves that indicate the effects of adding acid to pure water and to water samples from lower Marvine Lake and upper Island Lake (fig. 79). 


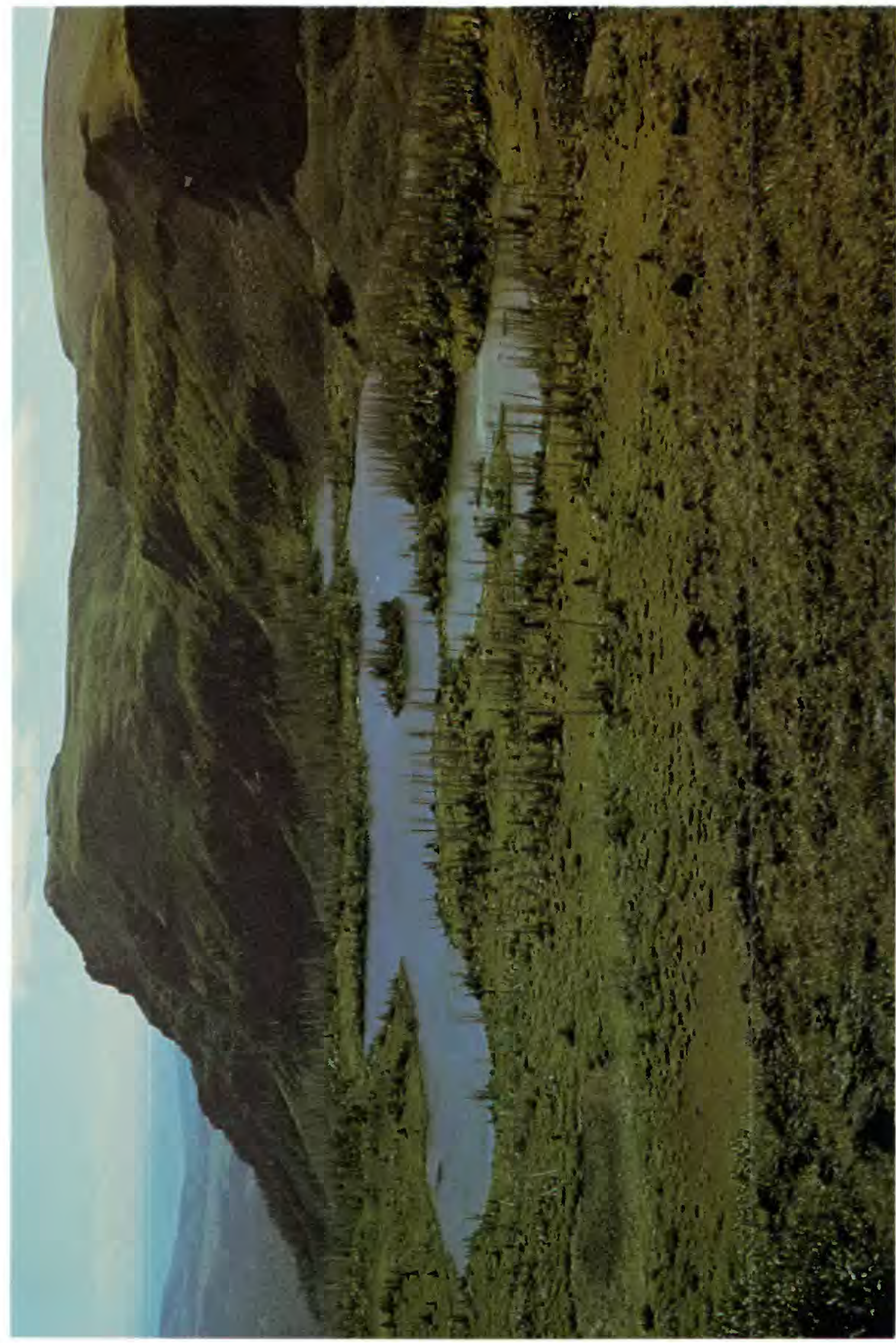

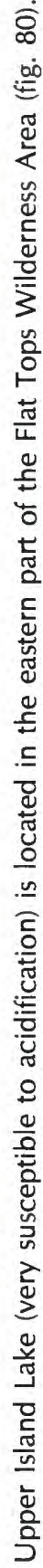




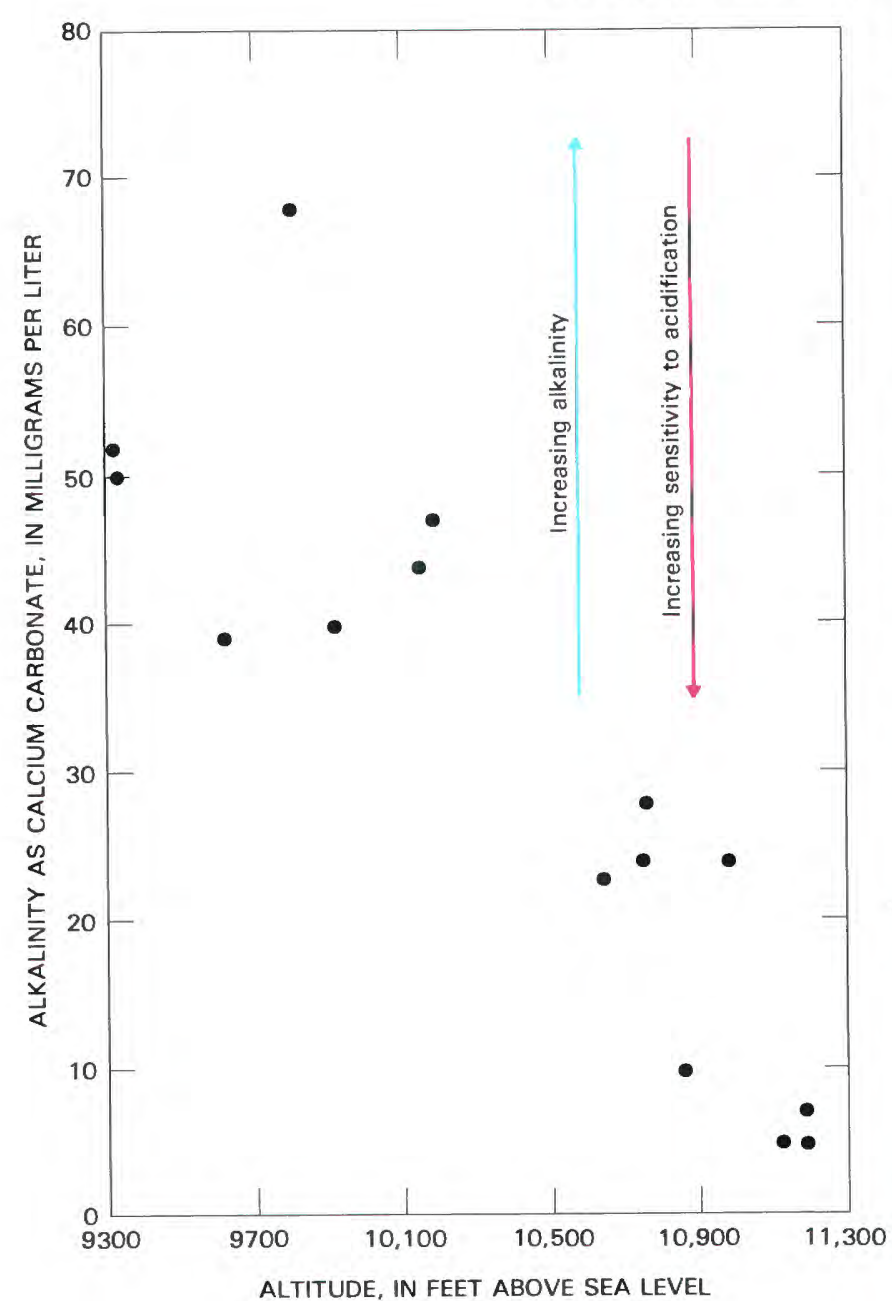

Sensitivity of lakes to acidification is a function of altitude (fig. 81).

\section{SIMULATION MODELS CAN BE USED TO STUDY THE EFFECTS OF EMISSIONS ON THE ATMOSPHERE, PRECIPITATION, AND LAKES}

Results of studies of lakes in the Flat Tops Wilderness Area indicate that many lakes have little ability to neutralize added acidity. Even small additions of acid to these lakes will decrease their $\mathrm{pH}$. The effects of incremental increases of emissions on these very sensitive lakes can be predicted using models that simulate acid deposition on the lake watersheds. The complex terrain of sensitive areas, such as the Flat Tops and Mount Zirkel Wilderness Areas, necessitates the development of atmospheric-transport and deposition models. Such models calculate the dispersion of emissions and the reactions that produce acidic components as functions of the location and sources of emissions.

The models also would calculate the average deposition rates of the acidic products on sensitive watersheds. Combined with data already available on the alkalinity of lakes in the watersheds, the effect on $\mathrm{pH}$ and fish can be approximated.

Even in the absence of emissions, natural processes result in a range of $\mathrm{pH}$ in sensitive lakes. As acid is added, however, the $\mathrm{pH}$ in all sensitive lakes will decrease. A basis for establishing standards for concentrations of constituents in emissions can be developed by calculating the concentrations that would cause the $\mathrm{pH}$ in some specified percentage of the lakes to decrease to values harmful to fish. These standards could reduce the cost of scrubbing equipment for retorts by requiring no more control than that necessary to prevent harm to most sensitive lakes.

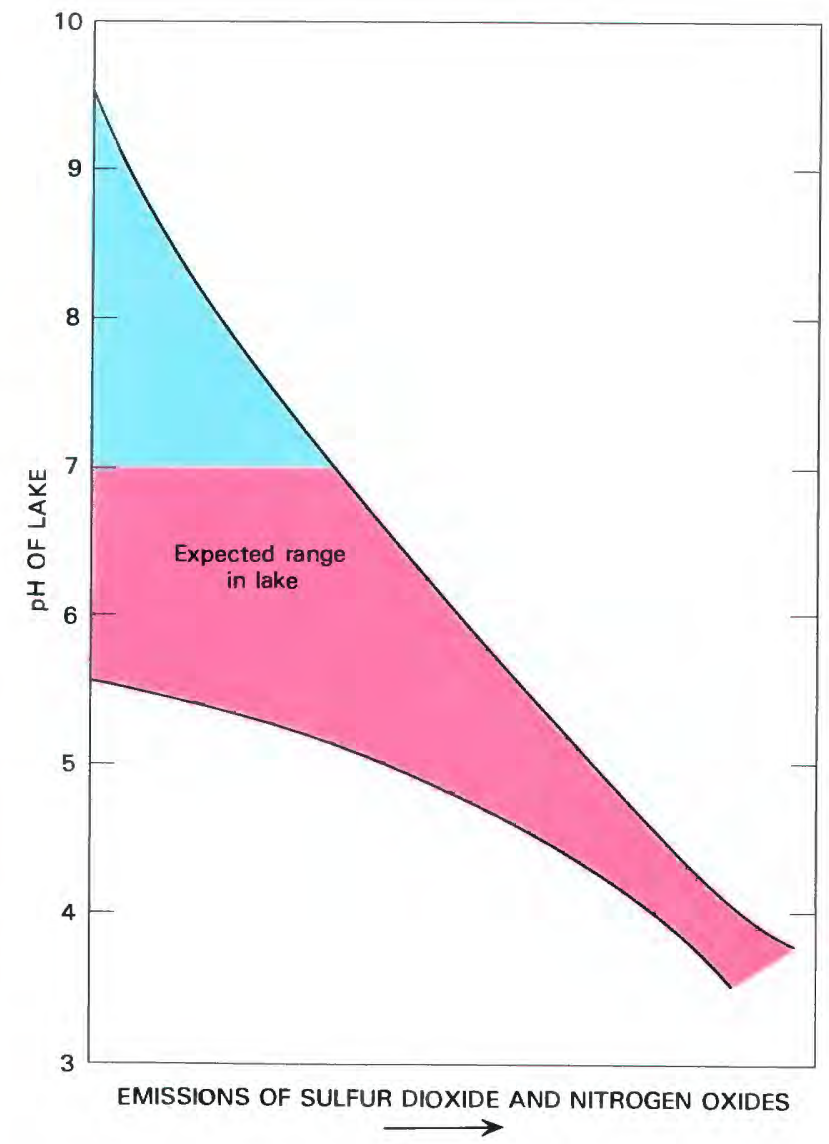

Simulation models to quantify the range in lake acidity as a function of emissions (fig. 82). 


\section{CONTROL TECHNOLOGY WILL REDUCE THE EFFECTS OF EMISSIONS FROM RETORTS}

Several procedures have been proposed to reduce the effects of emissions from retorts on hydrologic systems:

1. Scrubbing equipment can be installed on aboveground retorts to reduce the emissions to an acceptable level.
2. Affected lakes can be treated chemically to reduce the acidity of the lake water.

3. Affected watersheds can be treated chemically to reduce the acidity of water supplies over a large region.

The relative benefits, requirements, and effects of different levels of oil-shale development are analyzed in the final chapter. 


\section{LEVELS OF MINERAL DEVELOPMENT}




\title{
BENEFITS, REQUIREMENTS, AND EFFECTS OF DIFFERENT LEVELS OF OIL-SHALE DEVELOPMENT
}

\author{
BY O. JAMES TAYLOR
}

The development of oil-shale reserves will have several consequences. Production of shale oil can reduce or eliminate the dependence of our Nation on imported sources of crude oil. However, development will require new water supplies and will affect allocation of regional water resources.

Consequences of developing the minerals nahcolite and dawsonite associated with the oil shale are not considered in detail in this chapter, but they can be estimated. Certainly multimineral leasing and development will allow more efficient production of the associated minerals during mining activities principally devoted to oil-shale development. The required expanded development would result in increased volumes of waste for disposal in spoil piles. This additional waste also would contain leachable substances. Industrial water requirements would increase because of the expanded mining and development activity. However, the resulting increase in mineral production would be substantial and the economic efficiency could be high compared to the development of the associated minerals separate from the oil shale.

\section{THREE LEVELS OF DEVELOPMENT FROM OIL SHALE ARE CONSIDERED}

Oil production from shale will have effects on National crude-oil supplies and on water resources in the Piceance basin, and will have other impacts on the region. The effects are assessed for three levels of development: Level A presumes a small production, 200,000 barrels per day; level $\mathrm{B}$ presumes a moderate production, 2 million barrels per day; and level $C$ presumes an intense development, 6 million barrels per day.

Oil developmment from shale could reduce the need for other sources of domestic and imported crude oil. In 1980, average domestic crude-oil production was 8.6 million barrels per day; an additional 5.16 million barrels per day was imported. As the chart shows, with intense development, shale oil could replace most of the domestic crude oil or all of the imported crude oil, assuming 1980 usage. Small or moderate levels of development would have proportionately smaller effects.

\section{THE LEVEL OF PRODUCTION FROM OIL SHALE WILL AFFECT NATIONAL SOURCES OF OIL, THE FLOW OF DOLLARS OVERSEAS, AND DURATION OF OIL-SHALE RESERVES}

Possible changes in the amount of oil from different sources consumed in the United States were considered assuming that:

1. The National consumption rate will be constant, and

2. Shale oil will replace imported crude-oil supplies before production of domestic crude-oil is reduced.

The level-A development plan has little effect on crudeoil imports; the level-B development plan reduces required imports but does not affect domestic production of crude oil; the level-C development plan eliminates the need for imported crude oil and decreases the required production of domestic crude oil.

During 1980, about $\$ 64$ billion was spent on imported crude oil. The progressive increase in oil production from shale would allow corresponding decreases in expenditures for imported oil. The impact of oil-shale production on the flow of dollars overseas was estimated by deducting the 1980 price, $\$ 33.97$ per barrel, for each barrel of shale oil that would be produced. Intense development would eliminate all requirements for imported crude oil. Greater production of oil from shale could reduce the use of domestic crude oil, or the surplus could be exported.

\section{NOT ALL OF THE SHALE-OIL RESOURCE CAN BE RECOVERED, BUT THE RESERVES ARE LARGE ENOUGH TO SUPPLY OUR NATION WITH OIL FOR MANY YEARS}

Although the resource of shale oil in the Piceance basin totals 1.2 trillion barrels, only part of it can be recovered. The total amount that can be recovered depends on the accessibility of the oil shale for development, the method of mining used, and the retorting technique used. Improvements in mining and retorting technology probably will increase recovery, but effects of future improvements are difficult to predict. 


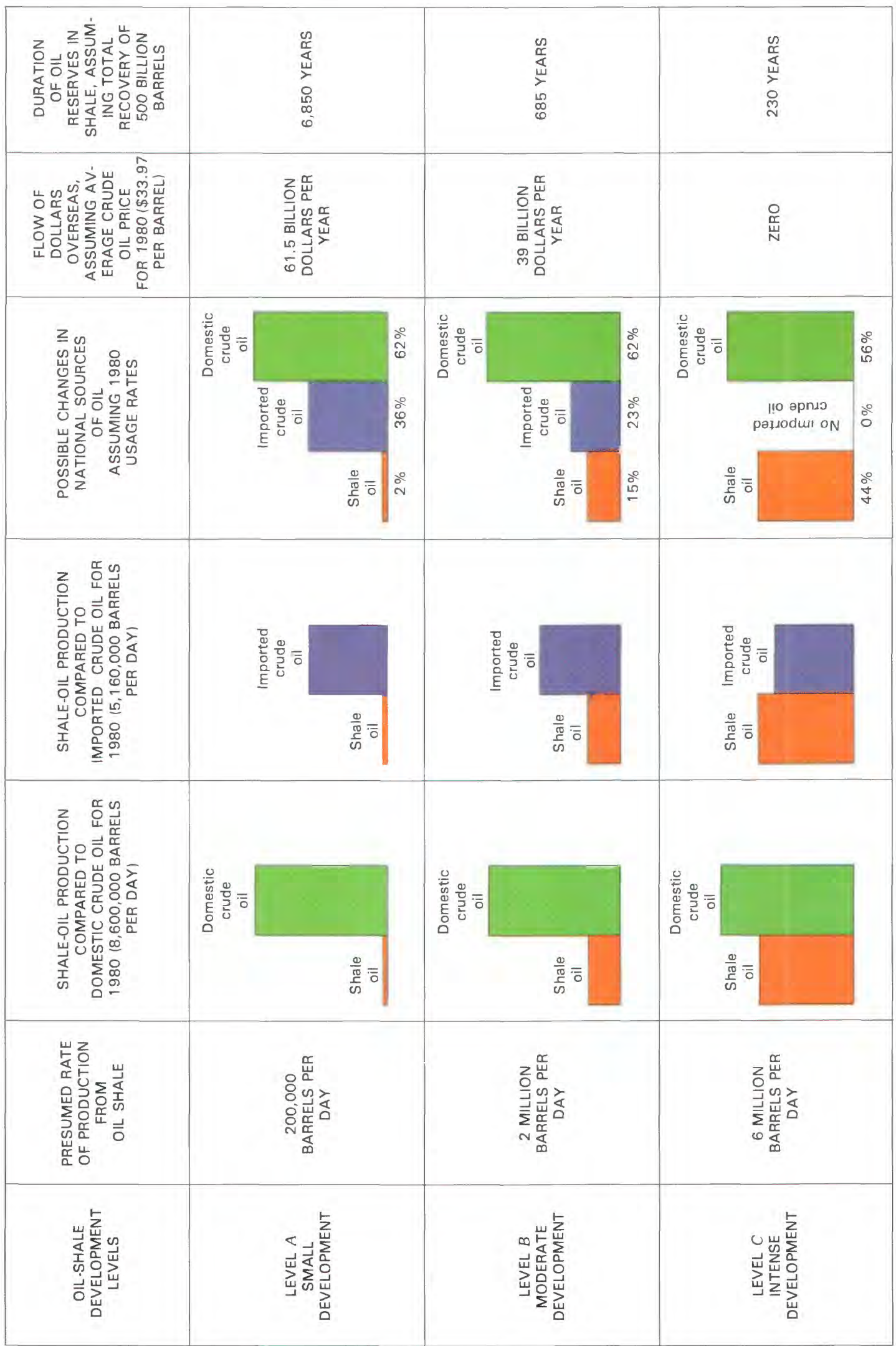


The accessibility of the oil shale is limited by several factors. A developer must acquire the proper lease or mining claim, or must purchase the minerals in order to have the legal right to development. Mining and safety laws also affect accessibility because some requirements and standards tend to decrease recovery. Additional limitations are imposed by the topography, streams, roads, and towns. Because of these limitations on the accessibility of oil-shale reserves, only an estimated two-thirds of the shale-oil, about 800 billion barrels, will be available for mining.

The fraction of the oil-shale resource which can be recovered also depends on the mining method. Various mining methods are described in the chapter "Development of oil shale and associated minerals." The room-and-pillar mining method is relatively expensive and normally recovers an average of about 45 percent of the ore in the mined zone. Underground mining in conjunction with in situ retorts is less expensive than room-and-pillar mining and commonly recovers about 60 percent of the ore. Within the retort, the recovery from in situ retorts will be less than 60 percent if the retorts are not adjacent to each other, and if intervening oil shale is not retorted. Open-pit methods are the least expensive and probably can recover about 80 percent of the ore. If we assume that 15 percent of the ore in the basin is mined by room-and-pillar methods, 25 percent by in situ retorting, and 60 percent by open-pit methods, then about 70 percent of the accessible ore, or about 560 billion barrels of shale oil would be recovered.

Finally, the recovery process depends on the efficiency of retorting. Aboveground retorts have demonstrated recoveries of about 95 percent of the shale oil in the feedstock. In situ retorts have lower recoveries, but technological improvements may result in recoveries as much as 75 percent in the future. A presumed recovery of nearly 90 percent from retorting processes indicates that about 500 billion barrels can be produced from the 1.2 trillion barrels of resource (less than 42 percent of the total). Nevertheless the oil-shale reserves are great compared to the total historical production of about 120 billion barrels of crude oil by the United States through 1979. The oil-shale reserves are more than four times larger than our total domestically produced crude oil from 1859 through 1979. However, the estimated reserves of shale oil are an approximation based on numerous assumptions.

Considering the three levels of shale-oil development, the duration of the 500 billion barrels of reserves was calculated. The duration ranges from hundreds to thousands of years.
The reserves would last more than two centuries, even at the intense development level of 6 million barrels per day. Obviously, the shale oil in the Piceance basin could supply our Nation far into the future.

\section{SURFACE-WATER SUPPLIES CAN PROVIDE WATER FOR OIL-SHALE DEVELOPMENT}

The water required for oil-shale development will be derived primarily from surface- and ground-water resources. Use of these water supplies can affect much of the Colorado River basin and should be assessed in a basinwide framework. The availability of surface water in the Upper Colorado River basin was analyzed in 1979 by the Colorado Department of Natural Resources for the U.S. Water Resources Council. This analysis compared water requirements for oilshale development and coal gasification with various water resources.

The analysis projected other consumptive uses of surface water in the upper basin based on limited information, but local detailed investigations will be needed. Federal environmental regulatory laws and programs and possible interstate compact constraints on surface water were not considered. The analysis assumed that:

1. Surface water not presently under contract will be purchased from existing reservoirs of the U.S. Bureau of Reclamation and (or) new reservoir, pipeline, and pumping facilities will be constructed.

2. Future average annual natural flow of the Colorado River at Lees Ferry will be 13.8 million acre-feet, equivalent to the estimated natural flow for 1930-74.

3. Average annual depletions by surface-water uses other than oil-shale development and coal gasification will increase about 42 percent by the year 2000 .

4. The Upper Colorado River Basin States will provide to Mexico 50 percent of the surface flow required by the Mexican Water Treaty; the other 50 percent of the required surface flow will originate in the Lower Colorado River Basin.

This analysis indicated that surface water might be obtained for oil-shale development in the White River and the Colorado River basins in Colorado. The supplies can be obtained by direct diversion from streams, water transfer from irrigation to oil-shale uses, a decrease in exports of water for municipal use, and an improvement in irrigation efficiency to decrease use. 
TABLE 5.-Potential surface-water supplies for oil-shale development in Piceance basin

\begin{tabular}{rr} 
DIVERSIONS FROM LOCAL STREAMS & ACRE-FEET PER YEAR \\
White River in Colorado - & 172,000 \\
Colorado River in Colorado-.-.-. & 68,000 \\
TOTAL & \\
\hline
\end{tabular}

TRANSFER FROM IRRIGATED AGRICULTURE

\begin{tabular}{cc} 
White River basin in Colorado---.. & 37.000 \\
$\begin{array}{c}\text { Roan and Parachute Creek basins } \\
\text { in Colorado-- }\end{array}$ & 10,000 \\
\hline & \\
\hline
\end{tabular}

REDUCED EXPORT FOR MUNICIPAL USE

Colorado River in Colorado

53,000 to 160,000

IMPROVED IRRIGATION EFFICIENCY

Colorado River Basin in Colorado

100,000
Deliberate weather modification in order to increase precipitation could result in increased surface runoff, according to the upper-basin analysis; because the techniques are uncertain, possible supplies resulting from this source were not included. The possible effects on amount and distribution of surface runoff from inadvertent weather modification by emission to the atmosphere were not studied.

\section{GROUND WATER AND IMPORTED SUPPLIES ALSO CAN PROVIDE WATER FOR OIL-SHALE DEVELOPMENT}

Other sources of water for oil shale include water that can be pumped from storage in the Green River and the Uinta Formations during mine drainage, deep ground-water supplies from storage in aquifers of Paleozoic and Mesozoic age in the Piceance basin or other basins in western Colorado, and imported ground and surface water.

Available water supplies from mine-drainage activities were estimated as follows: Natural recharge from precipitation to aquifers of the Green River and Uinta Formations probably averages about 36,000 acre-feet per year. The recharged water moves through aquifers to confining layers to zones of natural discharge where it contributes to streamflow. Exceptions are in some areas where water is evapotranspired from aquifers, but the volume of this consumption is not known.

Mine drainage will remove water from storage in aquifers at mine sites, and also may intercept ground water that normally would discharge to streams. Therefore, some water from mine drainage should be discharged back into the streams to replace the depleted streamflow. If the water resulting from mine drainage is not acceptable in quality to permit discharge into streams, either another source of better quality water can replace the depleted streamflow in an augmentation plan, or the owners of affected water rights can be compensated. Water law in Colorado relating to stream depletion is discussed in the chapter "Hydrologic system of the Piceance basin."

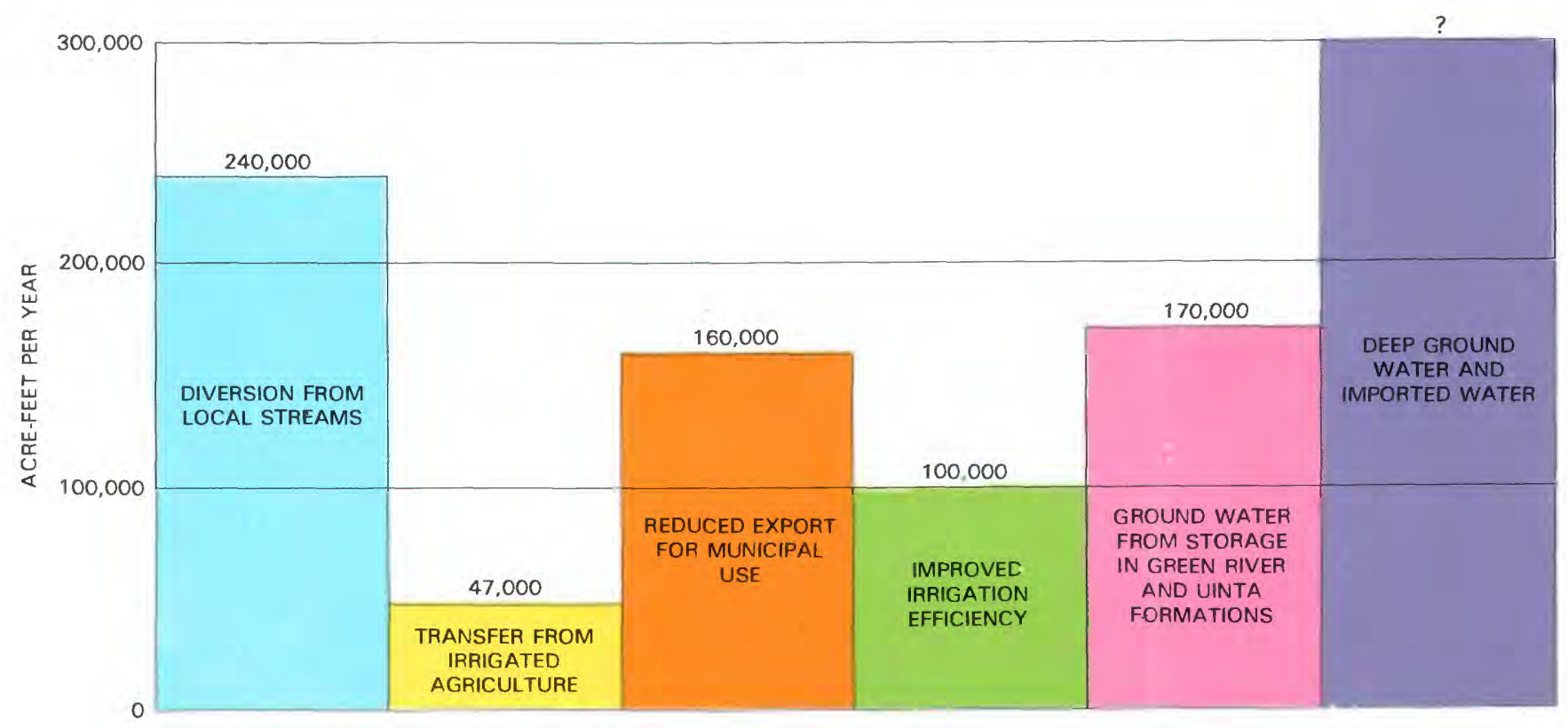

Estimated maximum available water supplies for oil-shale development in Piceance basin (fig. 84). 
As much as 36,000 acre-feet of water per year from mine drainage may have to be returned to the streams to replace lost contributions of ground-water discharge to streams during oil-shale development. If Piceance and Yellow Creeks became losing streams because bedrock aquifers beneath their valleys are drained, more than 36,000 acre-feet per year may have to be returned to streams, to replace both the depleted ground-water component and the loss of direct surface runoff as water moves from the stream into the bedrock aquifers and mines.

The volume of water that can be drained from the fractures, pores, and solution cavities in aquifers of the Green River and Uinta Formations throughout the Piceance basin is not known. However, if we presume that a basinwide average of between 2 and 3 percent of the volume of the bedrock contains water that can be drained by pumps for oil-shale development, the aquifers of the Green River and Uinta Formations contain about 40 million acre-feet of water in storage.

The approximate rate at which ground water can be pumped from storage was calculated by dividing the estimated total volume of ground water by the duration of each level of development. The resulting steady pumping rates are:

Level $A$ (200,000 barrels per day): 6,000 acre-feet per year Level $B$ ( 2 million barrels per day): 60,000 acre-feet per year

Level $C$ ( 6 million barrels per day): 170,000 acre-feet per year

Although natural recharge replenishes and maintains the ground-water system, it need not be considered in those calculations that relate to water that can be pumped from storage in bedrock aquifers because of the accompanying natural discharge.

Additional water supplies might be obtained from other sources, including deep ground-water reservoirs in the Piceance basin, other geologic basins in western Colorado, and surface water imported from other regions. However, the total amount of additional water available from these other sources is not known.

\section{THE LEVEL OF SHALE-OIL PRODUCTION MAY DETERMINE THE SOURCE OF WATER SUPPLY}

A mix of water supplies was designed for the estimated minimum and maximum total water required for each level of development. Different methods of operation are likely to use water supplies from a combination of different sources. The principal sources, in a presumed order of priority, are:

1. Ground water pumped from storage in aquifers of the Green River and Uinta Formations.

2. Diversion from local streams.
3. Transfer from irrigated agriculture.

4. Decreased export for municipal use.

5. Improved irrigation efficiency.

6. Deep ground water and imported water.

The sources of water for oil-shale development probably will depend on the level of development. The small development, level $A$, will require only four standard-size processing plants, each producing 50,000 barrels of oil per day. The ranges of industrial and ancillary water requirements have been totaled to obtain a range of total water requirements of 13,000 to 45,000 acre-feet per year (see table). Presumably, this relatively small requirement would come partly from ground water pumped from storage for mine drainage at a calculated rate of 6,000 acre-feet per year, and the remainder from diversion of surface water from the White and the Colorado Rivers. These two sources of water can meet the minimum and maximum requirements for level- $A$ development for 6,850 years, the expected duration of smalllevel development.

The moderate development, level $\mathrm{B}$, requires an estimated total of 130,000 to 450,000 acre-feet of water per year. Forty oil-shale processing plants would be required-about one every 40 square miles in the basin. The minimum requirement for water could be met by increased withdrawal of ground water from storage $(60,000$ acre-feet per year) and by surface-water diversions (70,000 acre-feet per year). However, the maximum requirement for level $B$ is greater than the combined supplies available from ground water in storage and surface-water diversions. Therefore, a transfer from irrigated agriculture and a large decrease in export for municipal use would also be necessary. However, major changes, such as irrigation structures, deep wells, and pipelines for water development would be avoided. The water supplies for level $B$ would need to be sustained for 685 years.

The intense development, level $C$, requires an estimated total of 400,000 to $1,300,000$ acre-feet of water per year. One hundred and twenty oil-shale processing plants would be required, about 1 every 13 square miles in the Piceance basin. Minimum water requirements can be obtained by withdrawal of ground water from storage and by surfacewater diversions. Maximum water requirements can only be met by using the maximum available supplies from all sources, including 583,000 acre-feet per year from deep ground water and imported water. Supplies derived from improved irrigation efficiency, deep ground water, and imported water will require structural changes and capital investment. Level- $C$ development will require dependable water supplies for 230 years.

The analysis of water requirements and sources indicates that a small level of development will not pose problems for water supply. Medium and intense levels of development will require supplies from several sources, especially if water requirements are near or at the maximum of the estimated range. 


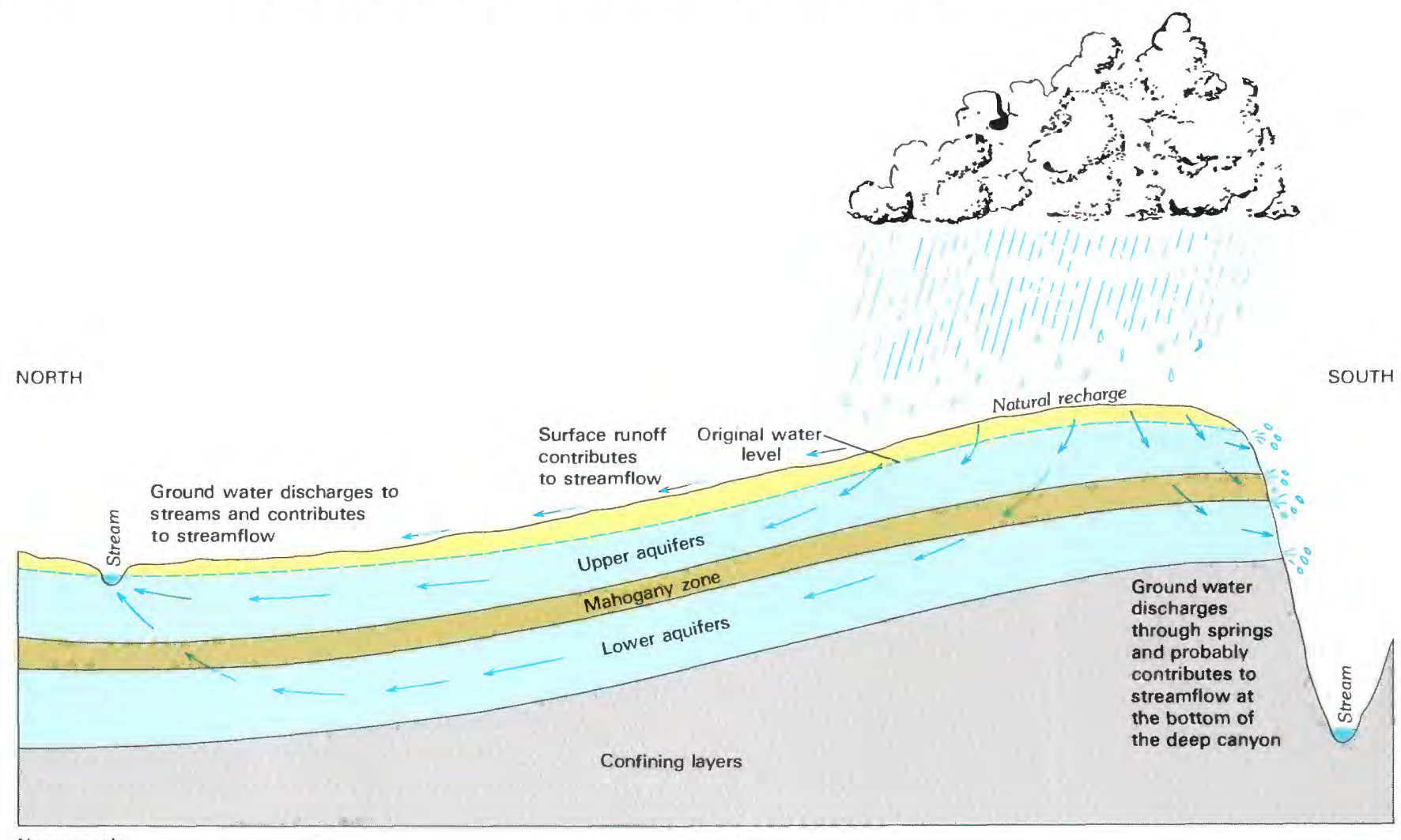

Not to scale

Natural hydrologic system before oil-shale development (fig. 85).
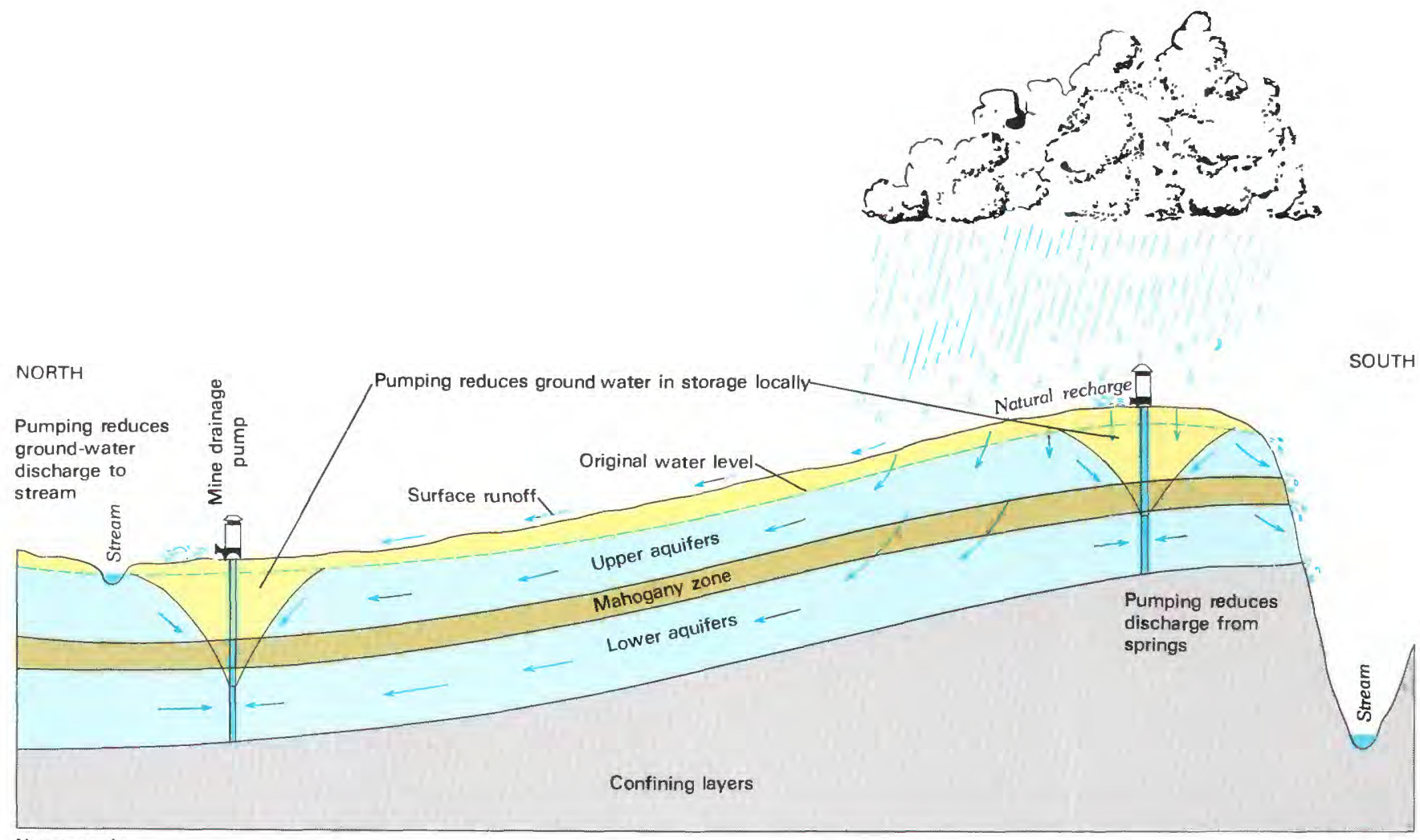

Not to scale

Effects of small oil-shale development on hydrologic system (fig. 86). 

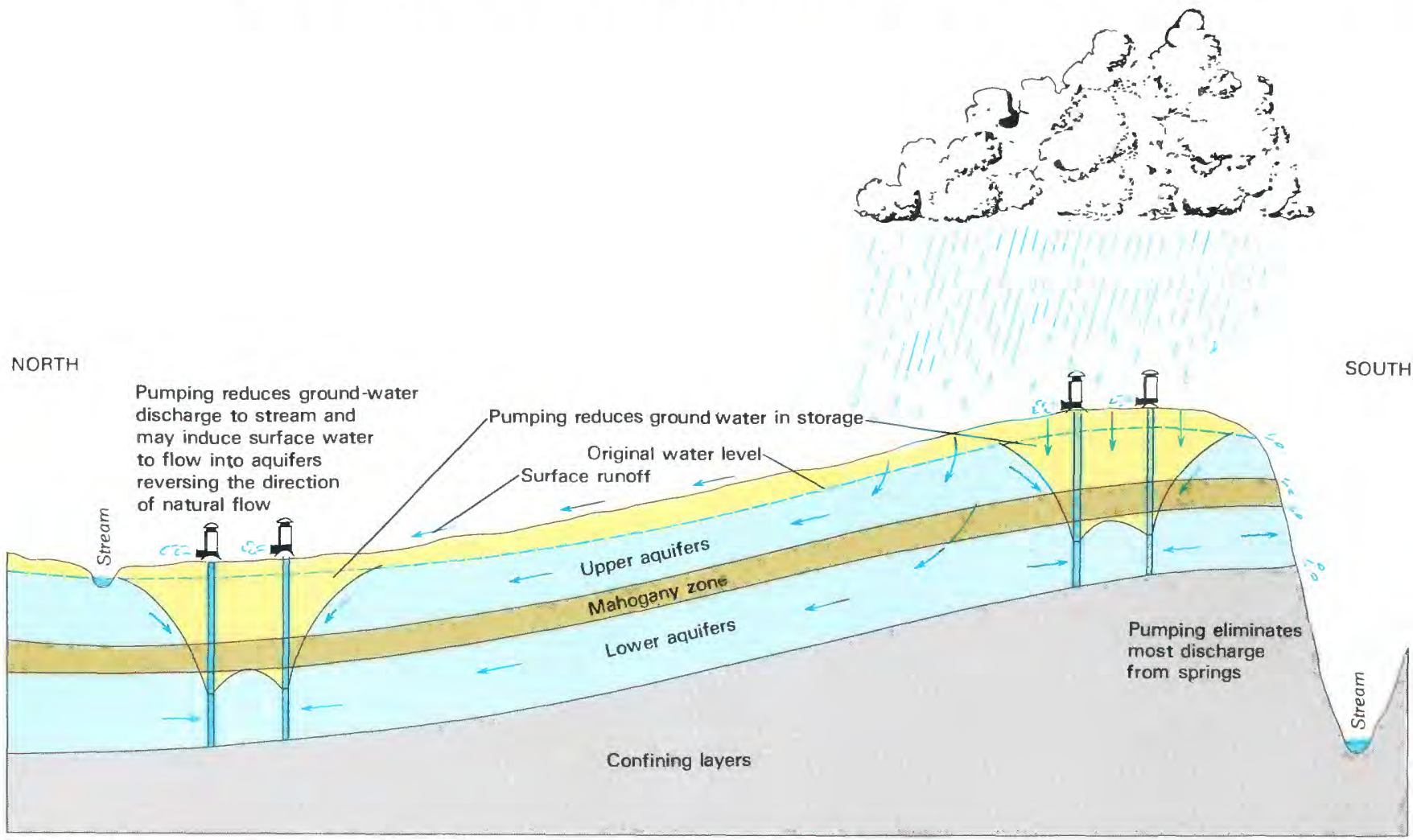

Not to scale

Effects of moderate oil-shale development on hydrologic system (fig. 87).

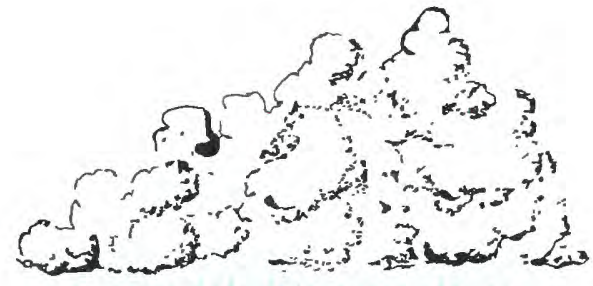

NORTH

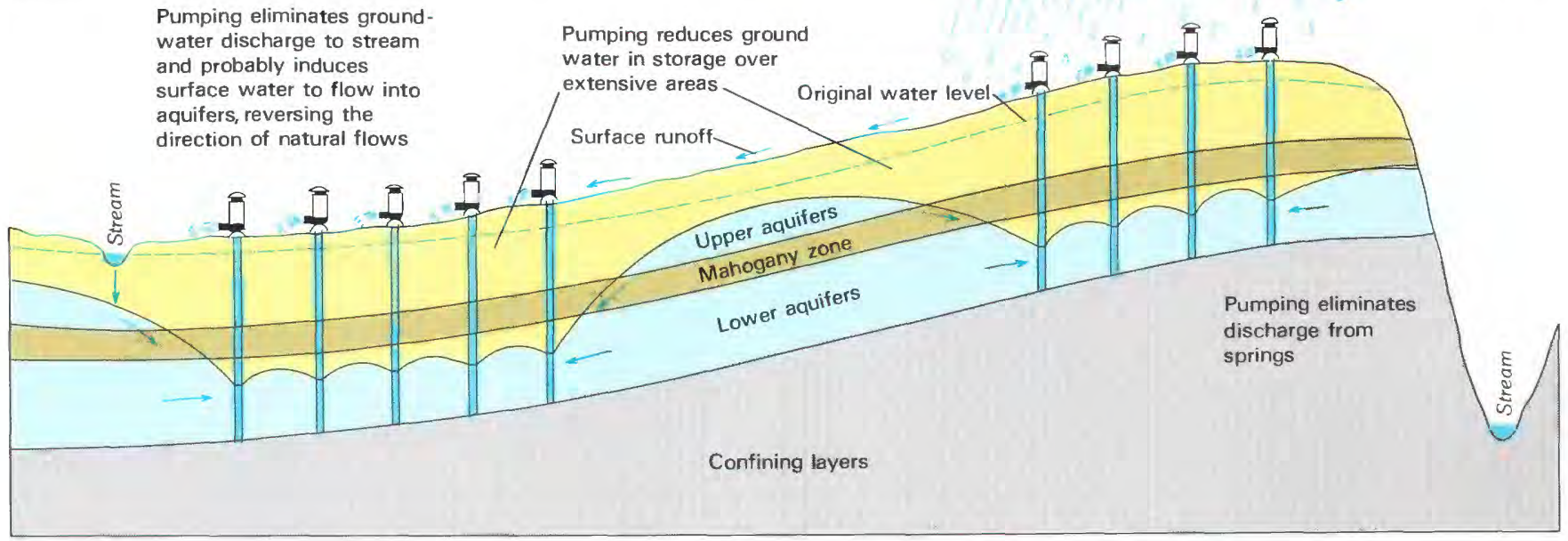

Not to scale

Effects of intense oil-shale development on hydrologic system (fig. 88). 


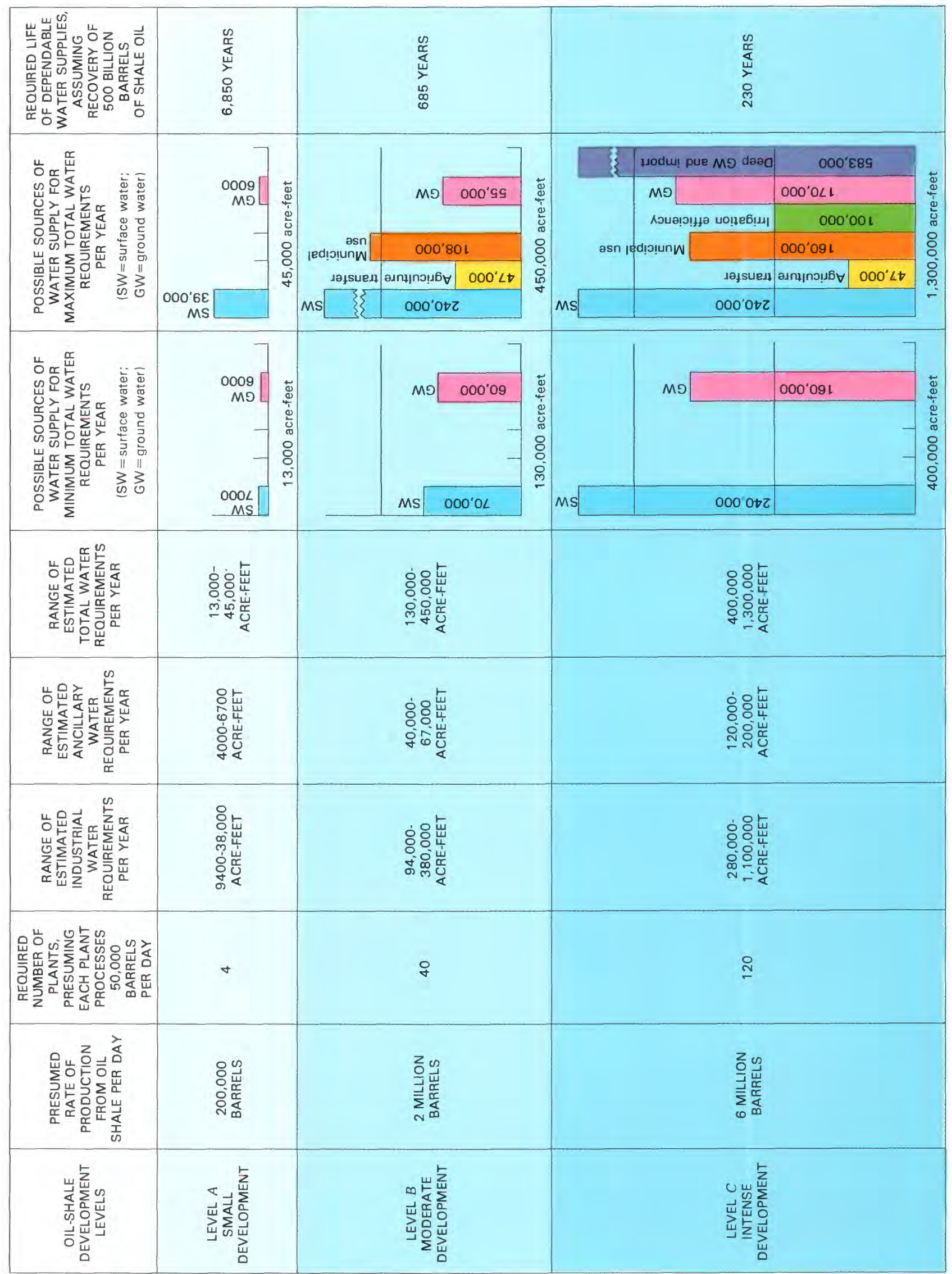




\section{DIFFERENT COMBINATIONS OF OIL-SHALE MINING AND RETORTING METHODS ARE ASSUMED}

The type of oil-shale development in the future cannot be predicted. Some developers prefer open-pit or underground mining with aboveground retorts; others prefer in situ processes. In order to estimate the impact of development on water resources, different combinations were presumed for each of the three levels of development.

First, 75 percent of the production was presumed to result from open-pit and underground mining using aboveground retorts, and 25 percent from in situ processes. Second, the proportions were reversed: 25 percent from mining using aboveground retorts, and 75 percent from in situ processes. Mining rates were calculated assuming that the average grade was about 0.3 barrel per ton of all mined material, including overburden. Furthermore, the calculations for in situ retorts presume that during construction about 25 percent of the rock within the retorts must be mined and retorted aboveground in order to prepare the in situ retorts. The calculations indicate that substantially less mining is required for predominantly in situ development because most of the extraction proceeds within oil shale that remains in place.

\section{THE AMOUNTS OF RETORTED SHALE THAT ARE DISPOSED OF ABOVEGROUND DEPEND ON THE LEVEL AND TYPE OF OIL PRODUCTION}

Mined material must be disposed of after aboveground retorting. Presumably the retorted shale will be backfilled into open pits, underground mine workings, or abandoned in situ retorts. However, the volume of the mined material commonly expands about 30 percent during crushing and retorting. Therefore, about 30 percent of the processed materials cannot be replaced in mined zones and must be discarded in spoil piles. The volume of retorted shale to be disposed of at the surface is much smaller for in situ processes because less material is removed from the mine.

Retorted shale may not be backfilled into underground mine workings or into abandoned in situ retorts because of the expense. In this case, the amounts of retorted shale disposed of in spoil piles aboveground will be greater than indicated in the table.

\section{IMPACTS ON WATER RESOURCES DEPEND ON THE LEVELS AND TYPES OF SHALE-OIL PRODUCTION}

\section{GROUND WATER}

The estimated impacts of shale-oil production on groundwater resources in the Green River and Uinta Formations can be summarized as follows:

1. The decrease of ground water in storage is not dependent on the types of development, because open pits, underground mines, and in situ retorts all need to be drained.

2. The decrease of ground water in storage depends on the level of development, as previously discussed.

3 . The sources of ground-water contamination are leachate from shale piles (retorted or unretorted shale), leachates from abandoned in situ retorts, and leakage from surface ponds.

4. The contamination hazard depends on the abundance of leachable contaminants and the location of shale piles and abandoned in situ retorts.

5. For high levels of development the hazard of abandoned in situ retorts may not occur for many years. The widespread effects of active mine-drainage pumps at numerous sites throughout the basin will prevent an abandoned retort from flooding, even though it is no longer pumped. The retorts will remain dry.

\section{DISCHARGE OF SPRINGS}

The discharge of springs depends on the level, but not the type, of development. A decrease of ground water in storage decreases spring discharge and eventually will cause some springs to cease flowing, especially where development is intense.

\section{STREAM DEPLETION}

The depletion of streams that results from oil-shale development depends on:

1. The level of development and accompanying minedrainage activities.

2. The locations of mines in relation to the streams and springs. Mine-drainage activities that are located near streams and springs will deplete streams more rapidly than distantly located drainage sites. 


\begin{tabular}{|c|c|c|c|c|}
\hline $\begin{array}{l}\text { OIL-SHALE } \\
\text { DEVELOPMENT } \\
\text { LEVELS }\end{array}$ & $\begin{array}{l}\text { PRESUMED RATE OF } \\
\text { DEVELOPMENT } \\
\text { FROM OIL SHALE }\end{array}$ & $\begin{array}{l}\text { PRESUMED TYPES OF } \\
\text { DEVELOPMENT }\end{array}$ & $\begin{array}{l}\text { AVERAGE REQUIRED } \\
\text { RATE OF MINING } \\
\text { IN TONS PER DAY }\end{array}$ & $\begin{array}{l}\text { AVERAGE DISPOSAL OF } \\
\text { RETORTED SHALE ABOVE- } \\
\text { GROUND IN CUBIC } \\
\text { YARDS PER DAY }\end{array}$ \\
\hline \multirow{4}{*}{$\begin{array}{c}\text { LEVEL } A \\
\text { SMALL } \\
\text { DEVELOPMENT }\end{array}$} & \multirow{4}{*}{$\begin{array}{l}200,000 \\
\text { BARRELS } \\
\text { PER DAY }\end{array}$} & $\begin{array}{l}\text { OPEN-PIT AND UNDER- } \\
\text { GROUND MINING; } 75 \text { PER- } \\
\text { ABOVEGROUND } \\
\text { RETORTING }\end{array}$ & \multirow[t]{2}{*}{540,000} & \multirow[t]{2}{*}{150,000} \\
\hline & & 25 PERCENT & & \\
\hline & & $\begin{array}{l}\text { OPEN-PIT AND UNDER- } \\
\text { GROUND MINING; } 25 \text { PER- } \\
\text { ABOVEGROUND } \\
\text { RETORTING }\end{array}$ & \multirow[t]{2}{*}{300,000} & \multirow[t]{2}{*}{80,000} \\
\hline & & 75 PERCENT & & \\
\hline \multirow{4}{*}{$\begin{array}{l}\text { LEVEL B } \\
\text { MODERATE } \\
\text { DEVELOPMENT }\end{array}$} & \multirow{4}{*}{$\begin{array}{l}2 \text { MILLION } \\
\text { BARRELS } \\
\text { PER DAY }\end{array}$} & $\begin{array}{l}\text { OPEN-PIT AND UNDER- } \\
\text { GROUND MINING; } 75 \text { PER- } \\
\text { ABOVEGROUND } \\
\text { RETORTING }\end{array}$ & \multirow[t]{2}{*}{$5,400,000$} & \multirow[t]{2}{*}{$1,500,000$} \\
\hline & & 25 PERCENT & & \\
\hline & & $\begin{array}{l}\text { OPEN-PIT AND UNDER- } \\
\text { GROUND MINING: } 25 \text { PER- } \\
\text { ABOVEGROUND } \\
\text { RETORTING }\end{array}$ & \multirow[t]{2}{*}{$3,000,000$} & \multirow[t]{2}{*}{800,000} \\
\hline & & 75 PERCENT & & \\
\hline \multirow{4}{*}{$\begin{array}{l}\text { LEVEL C } \\
\text { INTENSE } \\
\text { DEVELOPMENT }\end{array}$} & \multirow{4}{*}{$\begin{array}{l}6 \text { MILLION } \\
\text { BARRELS } \\
\text { PER DAY }\end{array}$} & $\begin{array}{l}\text { OPEN-PIT AND UNDER- } \\
\text { GROUND MINING; } 75 \text { PER- } \\
\text { ABOVEGROUND } \\
\text { RETORTING }\end{array}$ & $16,000,000$ & $4,500,000$ \\
\hline & & 25 PERCENT & \multirow{3}{*}{$8,800,000$} & \multirow{3}{*}{$2,400,000$} \\
\hline & & $\begin{array}{l}\text { OPEN-PIT AND UNDER- } \\
\text { GROUND MINING: } 25 \text { PER- } \\
\text { ABOVEGROUND } \\
\text { RETORTING }\end{array}$ & & \\
\hline & & 75 PERCENT & & \\
\hline
\end{tabular}

Estimated effects of presumed levels and types of oil development from shale on water resources (fig. 90 above and facing page).

3. The natural discharge from aquifers that replenishes the streams and springs. Pumping may cause stream depletion to capture all natural discharge. If extensive aquifer drainage occurs beneath Piceance and Yellow Creeks under intense development, direct surface runoff may recharge the aquifers and cause stream depletion greater than the rate of natural discharge.

\section{PRINCIPAL SOURCE OF STREAM CONTAMINATION}

Potential contamination of streams depends on the level and type of development. Erosion of shale piles could lead to contamination of streams. Contaminants leached from in situ retorts, shale piles, and surface ponds eventually may migrate to streams.

\section{CONTAMINATION OF NEARBY LAKES}

The acidification of nearby lakes that results from emissions from retorts to the atmosphere depends on the level but not on the type of development. The relations among development level, atmospheric emissions, and lake geochemistry are poorly understood. Those lakes that are supplied by contaminated streams also may become contaminated. The higher levels of development may produce lake contamination unless control technology is improved.

\section{WATER-RESOURCE SYSTEMS WILL RECOVER SLOWLY AFTER OIL-SHALE DEVELOPMENT}

The recovery of surface- and ground-water systems is difficult to predict. The general weather and climate patterns in the region probably will not change during development, but the land surface and aquifer systems will undergo large alterations. The contamination potential related to erosion and leaching will change, but not predictably. However, a recovery to conditions similar to those originally present in the basin will require more time than the development period-probably centuries. 


\begin{tabular}{|c|c|c|c|c|c|}
\hline \multicolumn{6}{|c|}{ ESTIMATED EFFECTS OF PRESUMED DEVELOPMENT } \\
\hline $\begin{array}{l}\text { REDUCTION OF } \\
\text { GROUND WATER IN } \\
\text { STORAGE PER YEAR }\end{array}$ & $\begin{array}{l}\text { PRINCIPAL SOURCE } \\
\text { OF GROUND-WATER } \\
\text { CONTAMINATION }\end{array}$ & $\begin{array}{l}\text { DISCHARGE OF } \\
\text { SPRINGS }\end{array}$ & $\begin{array}{c}\text { STREAM DEPLETION } \\
\text { PER YEAR }\end{array}$ & $\begin{array}{l}\text { PRINCIPAL SOURCE } \\
\text { OF STREAM } \\
\text { CONTAMINATION }\end{array}$ & $\begin{array}{l}\text { CONTAMINATION } \\
\text { OF NEARBY LAKES }\end{array}$ \\
\hline \multirow{2}{*}{$\begin{array}{l}6000 \\
\text { ACRE-FEET }\end{array}$} & $\begin{array}{l}\text { MINOR } \\
\text { LEACHATE } \\
\text { FROM SHALE } \\
\text { PILES }\end{array}$ & \multirow{2}{*}{$\begin{array}{l}\text { LOCAL } \\
\text { REDUCTION } \\
\text { AND } \\
\text { CESSATION }\end{array}$} & \multirow{2}{*}{$\begin{array}{l}\text { LOCAL AND } \\
\text { MINOR }\end{array}$} & $\begin{array}{l}\text { MINOR EROSION } \\
\text { AND LEACHATE } \\
\text { FROM SHALE PILES }\end{array}$ & \multirow{2}{*}{ NOT LIKELY } \\
\hline & $\begin{array}{c}\text { MINOR LEACHATE } \\
\text { FROM } \\
\text { ABANDONED IN } \\
\text { SITU RETORTS }\end{array}$ & & & $\begin{array}{c}\text { MINOR DISCHARGE } \\
\text { OF ANY } \\
\text { CONTAMINATED } \\
\text { GROUND WATER } \\
\text { TO STREAMS }\end{array}$ & \\
\hline \multirow{2}{*}{$\begin{array}{l}60,000 \\
\text { ACRE-FEET }\end{array}$} & $\begin{array}{l}\text { LEACHATE } \\
\text { FROM SHALE } \\
\text { PILES }\end{array}$ & \multirow{2}{*}{$\begin{array}{l}\text { REDUCTION } \\
\text { AND } \\
\text { CESSATION IN } \\
\text { SOME AREAS }\end{array}$} & \multirow{2}{*}{$\begin{array}{c}\text { AS MUCH AS } \\
36,000 \\
\text { ACRE-FEET } \\
\text { PER YEAR }\end{array}$} & $\begin{array}{c}\text { EROSION } \\
\text { AND LEACHATE } \\
\text { FROM SHALE PILES }\end{array}$ & \multirow{2}{*}{$\begin{array}{l}\text { POSSIBLE } \\
\text { UNLESS } \\
\text { CONTROL } \\
\text { TECHNOLOGY } \\
\text { IN IMPROVED }\end{array}$} \\
\hline & $\begin{array}{c}\text { LEACHATE } \\
\text { FROM } \\
\text { ABANDONED IN } \\
\text { SITU RETORTS }\end{array}$ & & & $\begin{array}{c}\text { DISCHARGE } \\
\text { OF ANY } \\
\text { CONTAMINATED } \\
\text { GROUND WATER } \\
\text { STREAMS }\end{array}$ & \\
\hline \multirow{2}{*}{$\begin{array}{l}170.000 \\
\text { ACRE-FEET }\end{array}$} & $\begin{array}{l}\text { WIDESPREAD } \\
\text { LEACHATE } \\
\text { FROM SHALE } \\
\text { PILES }\end{array}$ & \multirow{2}{*}{$\begin{array}{l}\text { WIDESPREAD } \\
\text { REDUCTION } \\
\text { AND } \\
\text { CESSATION }\end{array}$} & \multirow{2}{*}{$\begin{array}{l}\text { POSSIBLY MORE } \\
\text { THAN } 36,000 \\
\text { ACRE-FEET } \\
\text { PER YEAR }\end{array}$} & $\begin{array}{l}\text { WIDESPREAD } \\
\text { EROSION AND } \\
\text { LEACHATE FROM } \\
\text { SHALE PILES }\end{array}$ & \multirow{2}{*}{$\begin{array}{l}\text { LIKELY UNLESS } \\
\text { CONTROL } \\
\text { TECHNOLOGY } \\
\text { IS IMPROVED }\end{array}$} \\
\hline & $\begin{array}{l}\text { WIDESPREAD } \\
\text { LEACHATE } \\
\text { FROM } \\
\text { ABANDONED IN } \\
\text { SITU RETORTS }\end{array}$ & & & $\begin{array}{l}\text { WIDESPREAD DIS- } \\
\text { CHARGE OF ANY } \\
\text { CONTAMINATED } \\
\text { GROUND WATER } \\
\text { TO STREAMS }\end{array}$ & \\
\hline
\end{tabular}

\section{THE LEVEL OF DEVELOPMENT IS UNCERTAIN}

Oil-shale development is difficult to predict. National energy supplies probably will continue to be obtained from some combination of sources, including oil shale. The uncertainties in oil-shale development are related to:

1. The cost of developing shale oil in comparison to crude oil and other energy sources;

2. The possibility that additional energy sources will be discovered and induce a shift in use from one resource to another;

3. The partly unexplored water supplies that are necessary for development; and

4. The National demands for energy that are related to conservation, efficiency, price, lifestyle, and numerous unknown factors.

If oil-shale development is required for National energy supplies, adequate preparation time is crucial-the resource cannot be developed properly without it.

\section{COOPERATION IS THE KEY TO PROPER DEVELOPMENT}

Oil-shale and other mineral development is proceeding in the Piceance basin, and this development probably will continue. The challenge is to develop the minerals properly. The uncertain requirements and impacts of the industry complicate proper development. Nevertheless, plans can guide the development of the minerals in spite of these uncertainties. Those plans require cooperation at several levels.

Knowledge, judgment, and insight will be acquired by some of the technical people who specialize in the diverse technologies. These characteristics need to be shared cooperatively among all, so that the resulting knowledge can be propagated throughout the industry.

Cooperative endeavors among the operating levels of industry and government will be needed. The mutual use of facilities is desirable. For example, mining, retorting, disposal, and transportation facilities might be shared. Water supplies, reservoirs, or treatment plants could be operated in conjunction with each other. 
Finally, a cooperative commitment among the management levels of industry and government will insure that the minerals can be developed within the complex array of mineral, mining, water, and reclamation laws and regulations. These are the challenges and the choices in the Piceance basin.

\section{REFERENCES}

Colorado Department of Natural Resources, 1979, The availability of water for oil shale and coal gasification development in the Upper Colorado
River Basin, Draft of Upper Colorado River Basin 13(a) assessment; Report to the U.S. Water Resources Council: Denver Office of the Executive Director, Summary report, $157 \mathrm{p}$.

Dolton, G. L., and others, 1981, Estimates of undiscovered recoverable conventional resources of oil and gas in the United States: U.S. Geological Survey Circular 860, $87 \mathrm{p}$.

U.S. Department of Energy, 1980, International petroleum annual 1978: Energy Data Report DOE/EIA-0042(78), 35 p.

For those readers who wish to pursue the study of oil shale, associated minerals, and their development, a list of publications is provided in the following section. 


\section{ADDITIONAL INFORMATION}




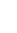




\section{RECOMMENDED READING}

\section{GEOLOGY AND MINERALS}

Beard, T. N., Tait, D. B., and Smith, J. W., 1974, Nahcolite and dawsonite resources in the Green River Formation, Piceance Creek basin, Colorado: Rocky Mountain Association of Geologists, Guidebook No. 25, Guidebook to the energy resources of the Piceance Creek basin, Colorado, p. 101-109.

Bradley, W. H., 1930, The varves and climate of the Green River epoch: U.S. Geological Survey Professional Paper 158-E, p. 87-110.

1931, Origin and microfossils of the oil shale of the Green River Formation of Colorado and Utah: U.S. Geological Survey Professional Paper 168, $58 \mathrm{p}$.

Cashion, W. B., 1967, Geology and fuel resources of the Green River Formation, southeastern Uinta Basin, Utah and Colorado: U.S. Geological Survey Professional Paper 548, 48 p.

Donnell, J. R., 1961, Tertiary geology and oil-shale resources of the Piceance Creek basin between the Colorado and White Rivers, northwestern Colorado: U.S. Geological Survey Bulletin 1082-L, p. 835-891.

1976, Global oil-shale resources and costs, in Meyer, R. F., ed., The future supply of nature-made petroleum and gas, technical reports: New York, Pergamon Press.

Dyni, J. R., 1974, Stratigraphy and nahcolite resources of the saline facies of the Green River Formation in northwest Colorado: Rocky Mountain Association of Geologists, Guidebook No. 25, Guidebook to the energy resources of the Piceance Creek basin, Colorado, p. 111-122.

Lillesand, T. M., and Kiefer, R. W., 1979, Remote sensing and image interpretation: New York, John Wiley \& Sons, 612 p.

Lundell, L. L., and Surdam, R. C., 1975, Playa-lake deposition; Green River Formation, Piceance Creek basin, Colorado: Geology, v. 3, no. 9, p 493-497.

MiLton, C., 1977, Mineralogy of the Green River Formation: The Mineralogical Record, September-October 1977, p. 368-379.

Roehler, H. W., 1974, Depositional environments of rocks in the Piceance Creek basin, Colorado: Rocky Mountain Association of Geologists, Guidebook No. 25, Guidebook to the energy resources of the Piceance Creek basin, Colorado, p. 57-64.

Ryder, R. T., Fouch, T. D., and Ellis, J. H., 1976, Early Tertiary sedimentation in the western Uinta basin, Utah: GeologicaL Society of America Bulletin, v. 87, p. 496-512.

Schaeffer, Bobb, and Mangus, Marlyn, 1965, Fossil lakes from the Eocene: Natural History, v. 74, p. 10-21.

Siegal, B. S., and Gillespie, A. R., eds., 1980, Remote sensing in geology: New York, John Wiley \& Sons, 702 p.

\section{HYDROLOGY, WATER SUPPLIES, AND WATER LAW}

Colorado Department of Natural Resources, 1979, The availability of water for oil shale and coal gasification development in the Upper Colorado River basin, Draft of Upper Colorado River Basin 13(a) assessment; Report to the U.S. Water Resources Council: Denver, Office of the Executive Director, Summary report, $157 \mathrm{p}$.
Hynes, H. B. N., 1970, The ecology of running waters: Toronto, University of Toronto Press, $555 \mathrm{p}$.

Radosevich, G. E., and Hamburg, D. H., compilers and eds., 1971, Colorado water laws, compacts, treaties and selected cases: Report prepared for Colorado State Engineer, Division of Water Resources, Department of Natural Resources, 205 p.

Robson, S. G., and Saulnier, G. J., Jr., 1980, Hydrogeochemistry and simulated solute transport, Piceance basin, northwestern Colorado: U.S. Geological Survey Professional Paper 1196, 65 p.

Taylor, O. J., 1982, Three-dimensional model for simulating the hydrologic system in Piceance basin, Colorado: U.S. Geological Survey Open-File Report 82-637, $40 \mathrm{p}$.

Taylor, O. J., compiler, 1983, Hydrologic information needs for oil-shale development, northwestern Colorado: U.S. Geological Survey WaterResources Investigations Report 82-4076, 92 p.

U.S. Department of the Interior, 1974, Water for energy in the Upper Colorado River Basin: U.S. Department of the Interior, Water for Energy Management Team, $71 \mathrm{p}$.

Weeks, J. B., Leavesley, G. H., Welder, F. A., and Saulnier, G. J., Jr., 1974, Simulated effects of oil-shale development on the hydrology of Piceance basin, Colorado: U.S. Geological Survey Professional Paper $908,84 \mathrm{p}$.

\section{DEVELOPMENT OF OIL SHALE AND ASSOCIATED MINERALS}

Dyni, J. R., 1982, Colorado nahcolite deposits: Geology and outlook for development: American Institute of Mining Engineers Transactions, v. 270, p. 1853-1859.

Exxon Corp., 1979, World energy outlook: New York, Exxon Corp. Background Series, Public Affairs Department, 32 p.

Hendrickson, T. A., compiler, 1975, Synthetic fuels data handbook: Denver, Cameron Engineers, Inc., 297 p. and appendix.

Lewis, A. E., 1979, Oil from shale-The potential, the problems, and a plan for development: Energy, Great Britain, Pergamon Press, v. 5, p. 373-387.

Meyer, Randall, 1981, Energy resource development in the western states (presented at Colorado School of Mines, Golden, April 2, 1981): Houston Tex., Exxon Co., Public Affairs Department, 18 p.

Nowacki, Perry, ed., 1981, Oil shale technical data handbook: Park Ridge, N.J., Noyes Data Corp., 309 p.

Occidental Petroleum Corp., 1980, Shale oil: Grand Junction, Colo., 28 p.

Rickert, D. A., Ulman, W. J., and Hampton, E. R., eds., 1979, Synthetic fuels development, earth-science considerations: U.S. Geological Survey Special Report, $45 \mathrm{p}$.

Russell, P. L., 1979, History of western oil shale: East Brunswick, N.J., The Center for Professional Advancement, $152 \mathrm{p}$.

U.S. Congress, Office of Technology Assessment, 1980, An assessment of oil shale technologies: Washington, D.C., U.S. Government Printing Office, $517 \mathrm{p}$. 


\section{IMPACTS OF OIL-SHALE DEVELOPMENT}

Bates, E. R., and Thoem, T. L., eds., 1980, Environmental perspective on the emerging oil shale industry: Cincinnati, U.S. Environmental Protection Agency, Office of Research and Development, Oil Shale Research Group, EPA-600/2-80-205a, 32 p.

Colorado Energy Research Institute and Colorado School of Mines, 1981, Oil shale 1982, a technology and policy primer: Golden, Colorado Energy, 93 p.

Likens, G. E., Wright, R. E., Galloway, J. N., and Butter, T. J., 1979, Acid rain: Scientific American, v. 241, no. 4, p. 43-51.

Shih, C. C., Cotter, J. E., Prien, C. H., and Nevens, T. D., 1979, Technological overview reports for eight shale oil recovery processes, prepared in cooperation with Denver Research Institute: Cincinnati, U.S. Environmental Protection Agency, Office of Research and Development, Partial fulfillment of EPA Contract 68-02-1881, EPA-600/7-79-075, 107 p; available from National Technical Information Service, Springfield, Va, as report PB-295 665/4ST, 115 p.

Slawson, G. C., Jr., and Yen, T. F., eds., 1979, Compendium reports on oil shale technology, prepared by General Electric Co.-TEMPO: Las Vegas, U.S. Environmental Protection Agency, Office of Research and Development, partial fulfillment of EPA Contract 68-03-2449, EPA-600/7-79-039, 202 p; available from National Technical Information Service, Springfield, Va., as report TB-279/6BE.

U.S. Environmental Protection Agency, 1977, Oil shale and the environment: Washington, U.S. Environmental Protection Agency, Office of Research and Development, EPA-600/9-77-033, 29 p.

U.S. Environmental Protection Agency, Oil Shale Research Group, 1981, Perspective on the emerging oil shale industry: Cincinnati, U.S. Environmental Protection Agency, EPA 625/9-81-005, 18 p.

Western Colorado Congress, 1981, Oil shale, a citizen's perspective: Montrose, Colo, $16 \mathrm{p}$. 



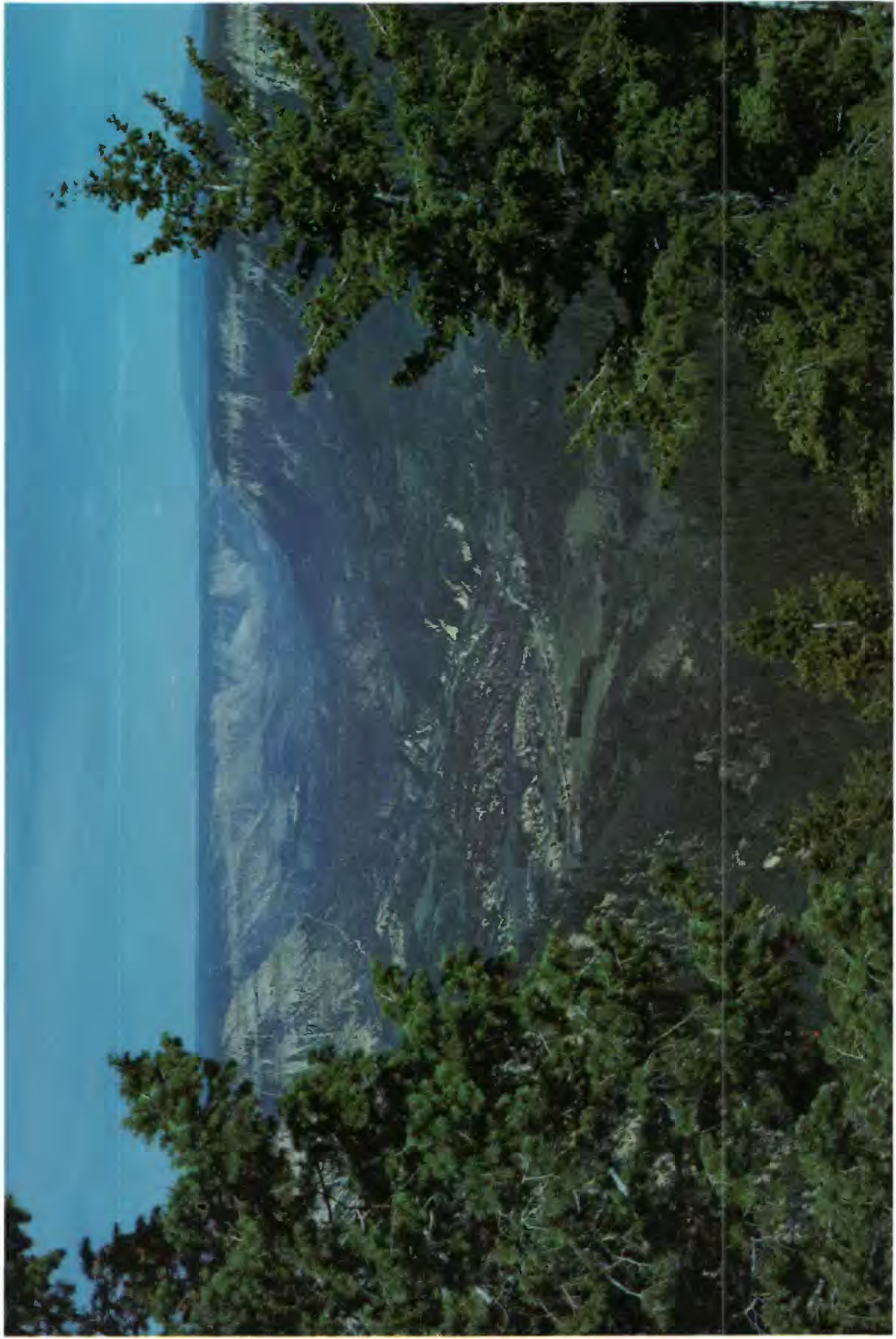




\section{EPILOGUE}

\section{BY O. JAMES TAYLOR}

The mineral resources of the Piceance basin are an abundant and varied National treasure. Studies of the basin have provided information on the interwoven geologic and hydrologic processes that caused the minerals to accumulate. An awareness of these processes is helpful in understanding the occurrence and association of these minerals and in predicting where they may be found.

The desirable level of mineral development-including the fundamental question of whether or not the minerals should be developed-is complex. Development will result in a variety of National benefits accompanied by regional disadvantages. The relative benefits and disadvantages also will depend on the duration of development, itself a function of the level of development.

Plans to develop the minerals can be improved by considering the conditions of mineral deposition, burial, and structural deformation. For example, mining and retorting can be designed to improve recovery, maintain safety, and reduce many undesirable effects of development in the basin-if the available information is used. Waste materials that result from mineral development will change the land surface of the basin, its water resources, and atmospheric conditions. The disadvantages of the changes can be reduced by actions that consider the interactions between the waste materials and the hydrologic systems.

Water resources for oil-shale development are paramount. The ground water that occurs with the minerals is a mixed blessing; it must be drained before mining but it will provide part of the supplies needed for development. The availability of additional supplies from streams, regional ground-water reservoirs, and other sources from which water might be imported, is uncertain.

Proper development will require additional information to ensure that the benefits outweigh the disadvantages. This information can be provided by Earth scientists-those remarkable men and women in government, industry, and universities whose imaginative and comprehensive investigations have provided the material discussed in this volume. 




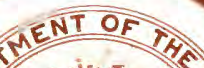

